\title{
Between the wheels: Quest for streetcar unionism in the Carolina Piedmont, 1919--1922
}

Jeffrey M. Leatherwood

West Virginia University

Follow this and additional works at: https://researchrepository.wvu.edu/etd

\section{Recommended Citation}

Leatherwood, Jeffrey M., "Between the wheels: Quest for streetcar unionism in the Carolina Piedmont, 1919--1922" (2009). Graduate Theses, Dissertations, and Problem Reports. 4489.

https://researchrepository.wvu.edu/etd/4489

This Dissertation is protected by copyright and/or related rights. It has been brought to you by the The Research Repository @ WVU with permission from the rights-holder(s). You are free to use this Dissertation in any way that is permitted by the copyright and related rights legislation that applies to your use. For other uses you must obtain permission from the rights-holder(s) directly, unless additional rights are indicated by a Creative Commons license in the record and/ or on the work itself. This Dissertation has been accepted for inclusion in WVU Graduate Theses, Dissertations, and Problem Reports collection by an authorized administrator of The Research Repository @ WVU.

For more information, please contact researchrepository@mail.wvu.edu. 
Between the Wheels:

Quest for Streetcar Unionism

in the Carolina Piedmont, 1919-1922

Jeffrey M. Leatherwood

Dissertation submitted to the Eberly College of Arts and Sciences at West Virginia University in partial fulfillment of requirements for the degree of

Doctor of Philosophy

in

American History

Kenneth Fones-Wolf, Ph.D., Chair Elizabeth Fones-Wolf, Ph.D. Michal McMahon, Ph.D. Peter Carmichael, Ph.D. Gerald Schwartz, Ph.D.

Department of History

Morgantown, West Virginia 2009 


\section{ABSTRACT \\ Between the Wheels: Quest for Streetcar Unionism in the Carolina Piedmont, 1919-1922 \\ Jeffrey M. Leatherwood}

Between the Wheels examines three Carolina Piedmont streetcar strikes in 1919-22.

These years were marked by the aspirations of workers for industrial democracy, corporate antilabor backlash and by the first Red Scare. Inevitably, these trends swept through the Carolina Piedmont, long viewed as isolated and resistant toward progress. But scholars should now reexamine the New South in light of broader American context. Three case studies in Spartanburg and Columbia, South Carolina, and Charlotte, North Carolina, highlight the struggles of New South labor reformers against union-busting monopolists, exemplified by James B. Duke.

During World War I, many Carolina Piedmont entrepreneurs viewed labor unionism as a direct threat to their well-entrenched system of exploitation and paternalism. Mill owners and their investors feared that successful streetcar unions could lead to renewed efforts to organize their textile mills. While Piedmont streetcar workers represented mere hundreds of skilled employees, regional textile mills employed thousands more unskilled workers, who were usually low-paid and poorly-treated by their employers and foremen. After World War I, Carolina streetcar employees and textile workers forged an informal alliance in opposition to Southern Power and other corporate interests.

The Amalgamated Association of Street and Electric Railway Employees (AASERE) met with resistance when its organizers sought to unionize the Piedmont's urban streetcar workers. In Charlotte, Southern Public Utilities Inc. employed armed strikebreakers, in defiance of the 
city's compromise solution. On the evening of August 25, 1919, Charlotte police officers and strikebreakers fired into a crowd of angry demonstrators, killing five men and wounding over twenty others. National Guardsmen quickly restored order in North Charlotte.

Charlotte's debacle resulted in setbacks for the struggling labor movement in the Carolina Piedmont. Over the next three years, textile mills crushed similar unionization efforts, while embryonic streetcar unions withered on the vine in Charlotte, Winston-Salem, and Durham, North Carolina. By 1922, this pattern of regression profoundly affected South Carolina, dislodging streetcar unions in Spartanburg and Columbia, where previous labor gains had resulted in partial or full recognition. By the 1930s, these New South streetcar lines faced oblivion due to financial receiverships and the rise of automobiles. 
Abstract.....................................................

Acknowledgements............................................ $\quad \mathrm{v}$

Chapter One: Between the Wheels.................................. 1

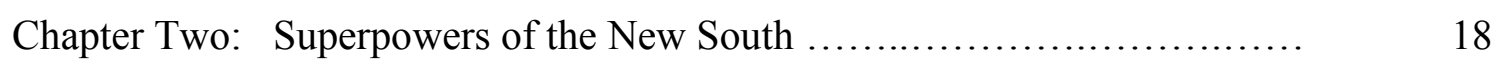

Chapter Three: Labor Forward in the Piedmont Carolinas................... 55

Chapter Four: The Great War Comes Home ............................. 85

Chapter Five: Grant Us a Contract ..................................... 109

Chapter Six: Battle of the Barn..................................... 135

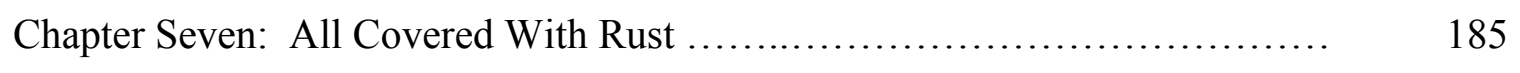

Chapter Eight: Epilogue and Conclusions ............................ 210

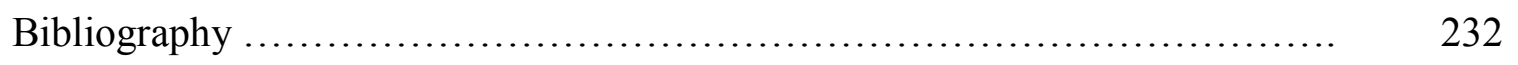




\section{Acknowledgements:}

Between the Wheels began in 2003 as my first graduate research paper on the Charlotte Streetcar Strike of 1919, supervised and nurtured by Dr. Gerald Schwartz at Western Carolina University. By the time I matriculated at West Virginia University for my doctoral program in 2004, my expanded term paper had been presented at conferences, not to mention an appearance in Western Carolina University's Tuskasegee Valley Historical Review. Little did I know how much more familiar I would become with its subject matter over the next five years!

At West Virginia University, Dr. Kenneth Fones-Wolf took an avid professional interest in my streetcar labor research. He guided my initial prospectus, encouraged my new angles of inquiry into Spartanburg and Columbia, South Carolina, and coached me on how to develop my dissertation chapters for possible publication. I also received generous support from the WVU Robbins Fellowship endowment in 2008, the same year my chapter on Spartanburg achieved publication in the South Carolina Historical Association journal. These two developments were confidence boosters, spurring me to complete my principal writing in less than two years.

I would like to thank my dissertation board, including Ken Fones-Wolf, Elizabeth Fones-Wolf, Michal McMahon, Peter Carmichael, and especially Gerry Schwartz for supporting this project from its inception. West Virginia University's History Department has been a source of inspiration and support, and I would also like to single 
out Chuck Dusch and Michael Buseman for being such great colleagues and friends throughout my graduate career in Morgantown.

Primary documents are essential to historical research, and this work would not exist without the generous assistance rendered by these institutions and personages: WVU's Wise Library and its West Virginia History \& Regional History Collection; University of South Carolina's Caroliniana Library at the "Horseshoe" in Columbia; the South Carolina Archives located on Parkland Road; Sheila Christopher and the Duke Energy Library in Charlotte; the Downtown Charlotte Public Library for making available their extensive newspaper archives; UNC at Chapel Hill's Louis Round Wilson Library for providing Allen Tullos's three interviews with Southern Public Utilities workers; University of Wisconsin at Madison for their kind inter-library loans of Motorman \& Conductor magazines on microfilm; lastly, the National Archives and Records Administration in Washington D.C. for providing valuable Department of Labor documents pertaining to Charlotte. If I have omitted any persons or institutions that rendered assistance to this dissertation, then I apologize to them in advance.

I would also like to show appreciation to two individuals who served as living connections to the principal actors and events of the Charlotte Streetcar Strike, almost ninety years after it took place. Ann Ritch Brantley and Samuel S. McNinch III shared personal reminiscences of their respective family members. Marvin Lee Ritch and Frank Ramsey McNinch remain two of the Piedmont's most fascinating historical figures, and each merits a biographer who can do their careers justice.

During the spring of 2007, my father passed away in Waynesville, North Carolina. Grady D. Leatherwood was a native son of Western North Carolina, with 
family members spread across the Blue Ridge Mountains as well as the Carolina Piedmont. This dissertation is hereby dedicated to my father's memory. I also express deep gratitude to my mother-in-law, Elaine Sherrill Rohr, for her archival knowledge and belief in my scholarly potential. Lastly, my wife, Jennifer E. Beck, deserves a special recognition for her longstanding emotional and intellectual support. 
Chapter 1: Between the Wheels

In late June 1919, Albert Essex Jones, special organizer for the streetcar workers' union, arrived in Spartanburg, South Carolina. His arrival heralded the American Federation of Labor's most ambitious campaign in a region long perceived as hostile toward unionism. For nearly a decade, the Amalgamated Association of Street and Electric Railway Employees (AASERE) had sought, without much success, to organize the Carolina Piedmont. In early July, Spartanburg's streetcar workers declared a strike. Partly owned by James B. Duke's Southern Power, South Carolina Light, Power, and Railway (SCLP\&R) supplied both power and transportation for local textile mills. Manager Franklin H. Knox engaged strikebreakers, but South Carolina’s governor, Robert A. Cooper, interceded before serious violence overwhelmed Spartanburg. Arbitrators secured Knox's agreement for better wages and schedules - albeit without union recognition.

Despite this setback, Jones glimpsed a greater opportunity to unionize three major Piedmont cities - Charlotte and Winston-Salem, North Carolina and Greenville, South Carolina -- served by Southern Public Utilities (SPU), a major branch of Southern Power. Just a month later, Jones mobilized nearly 300 streetcar men, who declared a strike on August 10 for better pay and union recognition. This transit strike paralyzed several Piedmont and Upcountry towns, as AASERE mobilized sympathy among the region's impoverished textile workers. SPU President Zebulon Taylor refused to acknowledge Jones as a legitimate representative, despite pressure from local and federal adjudicators. 
As a result, Charlotte's strike developed into a political impasse, with union sympathizers and progressives challenging the region's corporate establishment. ${ }^{1}$

Charlotte, the "Queen City" of North Carolina, served as the economic keystone that united the North Carolina Piedmont and South Carolina Upcountry during the Progressive Era. James B. Duke's ambitious electrification program became a significant catalyst in this urbanization process, which accelerated during the First World War. Headquartered in Charlotte, Southern Power quickly accumulated most of the traction companies in nearby Carolina towns. Duke and his fellow New South industrialists further acquired textile mills and other manufacturing assets across the entire Carolina Piedmont. Therefore, when Albert E. Jones expanded his union's post-war organization drive into Charlotte, he chose to enter the proverbial lion's den.

Even before World War I began, many Carolina Piedmont entrepreneurs viewed the transit union, AASERE, as the advance guard of a renewed effort to organized New South laborers. While the region's streetcar workers represented mere hundreds of employees, Carolina textile mills employed thousands more unskilled men and women, who were usually low-paid and poorly-treated by their employers and foremen. Many middle-class Southerners also looked down upon these "factory classes," who usually inhabited mill villages or urban tenements.

Mill owners and their investors especially feared that successful streetcar unions could lead to numerous and costly textile mill strikes over union recognition, particularly since streetcars were conduits of information for working-class riders. Mill workers also had a documented history of resentment toward their employers, as evidenced by two

${ }^{1}$ Charlotte Observer, 10 August to 23 November 1919; Greenville Daily News, 12 August 1919, 10; 15 August 1919, 10; 17 August 1919, 10. 
recent strikes in Greenville and Anderson, South Carolina. Unsurprisingly, labor organizers and rank-and-file unionists often valued these mill-hands as significant, if rather volatile, potential recruits. Throughout 1919 and beyond, electric streetcar employees and textile mill workers forged an informal coalition against the Piedmont region's well-entrenched system of exploitation and paternalism.

Nowhere is this working-class alliance better documented than the Charlotte streetcar strike of 1919. Hundreds of mill-workers rallied across Charlotte to protest Southern Public Utilities, especially after Zebulon Taylor sent armed replacements to man his streetcars. Several acts of strikebreaker intimidation worsened matters on August 25. Before long, a crowd of perhaps 2,000 townsfolk began picketing the Dilworth car-barn. Subsequently, Police Chief Walter B. Orr lost control of the strikebreakers and policemen guarding SPU property. Three protesters were killed outright, while two others subsequently died from mortal gunshot wounds. No policemen or replacement workers were among the dozens of injured reported at the "Battle of the Barn.” Considerable property damage resulted to SPU streetcars during a subsequent riot on August 26, which subsided only when National Guardsmen patrolled uneasy streets. Thwarted in their quest for a union, strikers returned to their jobs in early September. ${ }^{2}$

In the ensuing months, the political repercussions and legal proceedings dominated headlines in many regional newspapers. Charlotte's press transformed labor organizers into alien invaders. Meanwhile, the repressive violence perpetrated by the city police and strikebreakers underwent a similar transfiguration, ultimately finding

\footnotetext{
${ }^{2}$ This epithet for the Charlotte Strike appeared twenty years later in the official city history sponsored by the North Carolina Work Projects Administration; see Charlotte: $a$ Guide to the Queen City of North Carolina (Charlotte: News Printing House, 1939), 31-2.
} 
sanctification in Charlotte's courts. But the defeated streetcar strike did not simply reflect a city-wide reversal, as some previous historical treatments have implied. Charlotte's streetcar union, along with its new affiliates in Winston-Salem, North Carolina and Greenville, South Carolina, simply withered on the vine. None of these chapters sent representatives to national AASERE meetings. Moreover, Charlotte's crackdown on labor unions retarded further organization efforts in the Piedmont and Appalachia for the next decade, while the strike's long-term effects also reversed ten years of past labor progress.

These consequences were soon felt by organizing streetcar workers throughout Charlotte's sphere of influence. In Knoxville, Tennessee, another streetcar strike over union recognition occurred in October 1919. Knoxville's ruthless suppression of transit workers and allied coal-miners further weakened the tenuous grasp of unionism in eastern Tennessee. More ominously, Spartanburg's modest labor gains, mandated by South Carolina's governor in 1919, were soon revoked by South Carolina Light, Power, and Railway in early $1920 .^{3}$

The AASERE's final gasp of union activity in the Carolina Piedmont ended with the Columbia Street Railway Strike of 1922. During World War I, South Carolina's state capital enjoyed a mutually-beneficial relationship with its streetcar union. After his successful union rollback in Spartanburg, Franklin H. Knox took over management of the Columbia Railway, Gas, and Electricity Company in January 1922. To avoid bankruptcy, Knox discharged many employees, nearly all members of AASERE Division 590. Most of Knox's men elected to strike in sympathy, resulting in a year-long deadlock

\footnotetext{
${ }^{3}$ James A. Burran, "Labor Conflict in Urban Appalachia: The Knoxville Streetcar Strike of 1919." Tennessee History Quarterly, Vol. 38, No. 1, (Spring 1979), 62-78.
} 
in the courts and state legislature. Columbia's outcome virtually overturned the union's modest gains in Upcountry South Carolina, much as Charlotte had done to Piedmont North Carolina. In claiming this Pyrrhic victory against AASERE, however, Knox blacklisted his most experienced streetcar crewmen, ensuring Columbia Light, Gas \& Railway's (CLG\&R) inevitable decline in 1925. Thereafter, buses, jitneys, and private cars began to replace Columbia's failing streetcar lines. ${ }^{4}$

Between the Wheels contributes to several important literatures in modern American history. First, my work sharpens our understanding of general labor history. Often viewed in isolation, the Carolina Piedmont region witnessed the same post-war developments affecting the nation, and its history conforms to a larger narrative. Woodrow Wilson's political downfall weakened political support for Southern labor unions, while regional businessmen capitalized on the Red Scare to discredit labor unions. Hence, AASERE's protracted struggle in the Carolina Piedmont should be viewed contemporaneously with Washington's Centralia Massacre, the Great Steel Strike, West Virginia's Mine Wars, and the Railroad Shopmen's Strike of $1922 .{ }^{5}$

\footnotetext{
${ }^{4}$ Thomas Fetters did not mention the prior Spartanburg strikes of 1919 and 1920, despite the Knox connection. Duke's South Carolina transportation interests receive comprehensive treatment in this useful work. Thomas T. Fetters, Palmetto Traction (Forty Fort, PA: Harold E. Cox, 1978), 46-9; 86-94.

${ }^{5}$ See David Brody, Labor in Crisis: the Steel Strike of 1919 (Urbana \& Chicago: University of Illinois Press, 1965, 1987); Colin J. Davis, Power at Odds: the 1922 National Railroad Shopmen's Strike (Urbana \& Chicago: University of Illinois Press, 1997); Gene Smith, When the Cheering Stopped (William Morrow: New York, 1971). For more analysis on the First Red Scare, see also Eliot Asinof, 1919: America's Loss of Innocence (Donald Fine, Inc.: New York City, NY, 1990); Joseph A. McCartin, Labor's Great War (Chapel Hill, NC: University of North Carolina Press, 1997); William Millikan, A Union against Unions (St. Paul, Minnesota: Minnesota Historical Society
} 
Heartened by Woodrow Wilson's liberal victory in 1912, the Amalgamated Association of Street and Electric Railway Employees participated in the Labor Forward movement. At heart, Labor Forward remained a conservative labor movement, especially when compared to the more outspoken Industrial Workers of the World (IWW).

AASERE organizers had made cautious inroads in the Piedmont. Under the leadership of William D. Mahon, the national streetcar union had already established footholds in Asheville, North Carolina and Chattanooga, Tennessee. In Wilson's first year of office, the AASERE successfully unionized in Columbia, South Carolina's capital. But labor organizers also recognized their need to consolidate individual successes into a stronger regional network. For complete victory, the AASERE needed to wage a campaign for the hearts and minds of streetcar workers, while a favorable political climate still existed.

Between the Wheels demonstrates the AASERE's repeated collisions with the formidable James Buchanan Duke, who undoubtedly opposed the unionization of his Piedmont employees. No friend to Progressivism, Duke had been forced by the U.S. government to break up his tobacco monopoly just before World War I. However, Duke soon rekindled his lost fortunes through competitive textile, electrification, and transportation projects, which relied on low wages. By 1916, nearly all Carolina Upcountry street railways were outgrowths of Southern Public Utilities, Inc. (SPU), a major holding company for Southern Power. Some entrepreneurs, like Benette E. Geer and Zebulon V. Taylor, became Duke's partners. Historian Robert F. Durden, whose

Press, 2001); David Mitchell, 1919: Red Mirage (MacMillan Company: New York City, NY, 1970). 
writings have been uniformly favorable toward Duke, uses the word "empire," even characterizing Duke's foreign tobacco enterprises as nothing less than an "invasion. ${ }^{6}$

With America's entry in World War I, it was now labor's turn to invade Duke's corporate empire in the Carolina Piedmont. The AFL had enjoyed a spurt in membership growth, chiefly owing to AFL President Samuel Gompers's political alliance with the Wilson Administration. The pro-labor reformer Frank Walsh became chairman of the influential U.S. Commission on Industrial Relations, a bipartisan Congressional Commission investigating labor abuses across America. Wilson further rewarded his labor supporters by appointing a former United Mine Workers leader, William B. Wilson, as U.S. Labor Secretary. During the war years, Woodrow Wilson's administration also established the National War Labor Board to arbitrate wage disputes and strikes with relative impartiality. ${ }^{7}$

Where does this study fit within New South literature? In 1976, Gerald Carpenter presented his research on the New Orleans Street Railway Strike of 1929, noting that many Southern labor historians were too focused upon textile workers, while "virtually ignoring" trade unions in the New South. He also criticized "standard generalizations." Conventional wisdom insisted that the South presented a "united front against the alien

\footnotetext{
${ }^{6}$ Durden, 39-55, 67-84.

${ }^{7}$ Joseph A. McCartin, Labor's Great War (Chapel Hill, NC: University of North Carolina Press, 1997), 19-20; See also Samuel Yellen, American Labor Struggles (Harcourt, Brace and Company: New York City, NY, 1936); Graham Adams, Jr., Age of Industrial Violence, 1910-1915 (New York \& London: Columbia University Press, 1966), P.K. Edwards, Strikes in the United States, 1881-1974 (New York City, NY: St. Martin's Press, 1981).
} 
doctrine of trade unionism." Carpenter urged future labor scholars to re-examine these long-held interpretations of Southern history. ${ }^{8}$

Certainly, the plight of textile mill workers coincided with those of Piedmont streetcar workers. Historians of Southern mill worker protest have focused on the wellknown Great Depression textile strikes, without looking at earlier textile strikes, such as the 1919 Wiscasset Mill strike in North Carolina. Therefore, this research complements Bryant Simon's excellent A Fabric of Defeat, which concerns South Carolina's long war against the National Textile Workers Union, ending with the unsuccessful regional strike of 1934. Allen Tullos similarly addresses Carolina Piedmont labor unrest throughout the 1920s in his work, Habits of Industry. ${ }^{9}$

Conventional labor literature also suggests that Southern workers were difficult to organize, particularly before 1929. Piedmont Carolina streetcar employees were lowpaid, much like the South's textile workers. But unlike many textile workers, streetcar unions in the Carolinas did receive local support, even contractual recognition, such as in the cases of Columbia, South Carolina, or Asheville, North Carolina. One questions the popular image of the monolithic South, uniformly opposed toward organized labor.

Between the Wheels is also a study in Southern Progressivism. Southern Progressives held a number of influential positions in the Carolina Piedmont. Southern Progressivism has been examined by respected historians such as William Link and

\footnotetext{
${ }^{8}$ Gerald Carpenter, "Public Opinion in the New Orleans Street Railway Strike of 1929-1930," from Essays in Southern Labor History: Selected Papers, Southern Labor History Conference, 1976 (Westport, Connecticut: Greenwood Press, 1977), 191-207.

${ }^{9}$ John A. Salmond, Gastonia 1929 (Chapel Hill \& London: University of North Carolina Press, 1995), 188-9; Bryant Simon, A Fabric of Defeat: The Politics of South Carolina Millhands, 1910-1948 (Chapel Hill: University of North Carolina Press, 1998); Allen Tullos, Habits of Industry (Chapel Hill: University of North Carolina Press, 1989), 134-71.
} 
Dewey Grantham. Link's research identified "two fundamental values" clashing in the New South; "the paternalism of [Northern] reformers and the... community power of [Southern] traditionalists." However, this dissertation examines native Southerners who embraced political reform and supported labor unionism. ${ }^{10}$

Most of these Southern Progressives were products of Southern urban centers that sprang up during Reconstruction and would continue to grow into the next century. Several historians have examined cities as diverse as Charlotte and Columbia. Charlotte Mayor Frank R. McNinch espoused labor unionism, albeit a conservative model, and consistently fought against utility monopolies. In Spartanburg, South Carolina, newspaper editor Charles Hearon openly speculated whether well-disciplined labor unions might help ensure higher safety standards in public transportation. Charlotte attorney Marvin L. Ritch sacrificed his career to support streetcar workers. Columbia's labor community also boasted a newspaper, which circulated briefly during the postwar years. Meanwhile, one South Carolina state congressman, Ambrose A. Gerald, even served as Columbia, South Carolina's AASERE chapter president. ${ }^{11}$

According to Dewey Grantham, one of Southern Progressivism's major hallmarks was a "desire to expand the [state's] regulatory function in behalf of economic opportunity." Reformers increasingly came to view Southern Power as a monopolistic

${ }^{10}$ William Link, The Paradox of Southern Progressivism, 1880-1930 (Chapel Hill: University of North Carolina Press, 1992), xii; Dewey Grantham, Southern Progressivism: The Reconciliation of Progress and Tradition (University of Tennessee Press, Knoxville, 1983), 258.

${ }^{11}$ David Carlton, Mill and Town in South Carolina 1880-1920 (Baton Rouge and London: Louisiana State University Press, 1982); Janette T. Greenwood, The Black and White Better Classes in Charlotte (University of North Carolina Press: Chapel Hill \& London, 1994); Thomas W. Hanchett, Sorting Out the New South City (Chapel Hill \& London: University of North Carolina Press, 1998). 
threat to economic opportunity. This feeling culminated with North Carolina's regulatory impulse against Duke. Regulation to protect smaller businesses fits historically with Woodrow Wilson's presidential campaign for "New Freedom.” But like Wilson, many Southern reformers, were also proponents of racial segregation. Others, like Mayor Frank R. McNinch, expressed nativism in their support for immigration restriction during the 1920s. Moreover, Southern Progressives were deeply divided over the issue of child labor in textile mills. ${ }^{12}$

Even as Progressivism ebbed nationally during World War I, both Carolinas entered their own phases of reform, with progressive state governors and house delegates swept into office after Wilson's narrow re-election in 1916. Governor Thomas H. Bickett and North Carolina's General Assembly launched their anti-monopolist rate war against Duke's Southern Power. Meanwhile, South Carolina drifted toward state-mandated reforms. After the controversial Coleman Blease administration (1910-14), two Progressive Democratic governors took office in Columbia, South Carolina. Richard Irvine Manning and Robert Archer Cooper launched tax-based efforts to improve state highways and improve the quality of public education. They even broke the power of company stores in Upcountry mill towns. Despite the Palmetto State's lack of a Department of Labor until the late 1930s, unions expanding their presence could hope for tolerance at the state level. However, middle-class constituents in New South cities merely desired cheap and reliable public transportation, and as strikes disrupted the

\footnotetext{
${ }^{12}$ Grantham, 111, 360-1.
} 
normal flow, these citizens turned to alternative modes, such as jitneys and motor-buses, and increasingly the private automobile. ${ }^{13}$

This research also examines the First Red Scare as it affected the Piedmont Carolinas after World War I. In late 1918, the AASERE and other AFL unions seized windows of opportunity to penetrate the Carolina Upcountry. However, this region had always been suspicious of labor organizers who were, often as not, Northerners. Reactionary impulses were also unleashed during the war against Germany, and subsequent Allied interventions against Bolshevism in Archangel and Siberia. ${ }^{14}$ By 1919, Woodrow Wilson's political force had been nearly spent on foreign crusades. Meanwhile, industrialists across the United States had begun to retrench against the wartime gains of labor. Republicans had regained control of Congress in 1918, forcing the premature closure of the National War Labor Board in early 1919. Consequently, American businessmen revitalized their "open-shop" propaganda, combining their arguments with elements of a conspiracy theory. Following the recent Bolshevik Revolution in Russia, American organized labor across the nation became tainted with putative connections to the "Red Menace."15

${ }^{13}$ Robert M. Burts, Richard Irvine Manning and the Progressive Movement in South Carolina (Columbia: University of South Carolina Press, 1973), 70-144; See also Walter Edgar, South Carolina: a History (Columbia: University of South Carolina Press, 1998).

${ }^{14}$ Robert M. Burts, Richard Irvine Manning and the Progressive Movement in South Carolina (Columbia: University of South Carolina Press, 1973); Frank L. Grubb Jr., The Struggle for Labor Loyalty (Durham, North Carolina: Duke University Press, 1968); William Link, The Paradox of Southern Progressivism, 1880-1930 (Chapel Hill: University of North Carolina Press, 1992); McCartin, 69-75.

${ }^{15}$ See Allen Wakstein, "The Origins of the Open Shop Movement," Journal of American History. Vol. 51, No. 3 (Dec. 1964), 460-75; David Mitchell, 1919: Red Mirage (MacMillan Company: New York City, NY, 1970); William Millikan, A Union against Unions (Minnesota Historical Society Press: St. Paul, Minn., 2001). 
Transportation historians have heretofore focused mostly on Northern and Midwestern events. One of the best, Scott Malloy's Trolley Wars, focuses on Northern urban centers and streetcar unionism during the Progressive Era. However, only a few transportation scholars have paid attention to the South, and such publications often deal less with streetcar workers themselves. Thomas Fetters' exhaustive study of South Carolina streetcar lines, Palmetto Traction, covers parts of North Carolina and Georgia as well. Fetters' 1978 research may not be scholarly, but it does provide useful background on Upcountry streetcar lines, as well as their bewildering changes of ownership. While Palmetto Traction did not cover any streetcar strikes in Spartanburg or Greenville, he provided coverage in detail to Columbia's paralyzing 1922 walkout, not to mention the general decline of South Carolina streetcar transportation. Fetters also co-authored the official history of Duke's Piedmont \& Northern electric railway. ${ }^{16}$

Some scholars have devoted historical journal articles to Southern transit strikes. Since 1976, two significant peer-reviewed articles have emerged, dealing with contemporary problems in Appalachian transportation history. In 1979, James Burran published his research concerning the October 1919 Knoxville, Tennessee strike, which took place shortly after the Charlotte streetcar strike in August. James B. Jones Jr. later wrote about organization efforts in Chattanooga, Tennessee at the turn of the century,

\footnotetext{
${ }^{16}$ Scott Malloy, Trolley Wars: Streetcar Workers on the Line (Smithsonian Institute Press, Washington D.C. and London, 1996); Thomas T. Fetters and Peter W. Swanson, Piedmont \& Northern: The Great Electric System of the South (San Marino, Calif.: Golden West Books, 1976); Palmetto Traction, 86-94.
} 
culminating with a violent two-month strike in the fall of 1917, during the height of U.S. mobilization for World War I. ${ }^{17}$

Chattanooga and Knoxville's proximity to the Carolina Piedmont suggests that this region's unionization efforts did not occur in a vacuum. Moreover, Chattanooga and Knoxville's unions were established well before the labor struggles of 1919, providing a staging ground for further organization. Chattanooga's streetcar workers, like those in Anderson and Greenville, showed internal divisions over union membership and Northern leadership. Knoxville’s October 1919 strike took place subsequently (perhaps consequently) after the reversals of Charlotte. Future investigation may demonstrate that anti-labor backlash from the Carolina Upcountry spilled over to Eastern Tennessee, weakening tenuous union support in Knoxville. My research underscores a renewed need for regional assessments in New South labor history, instead of merely focusing on individual towns and isolated events.

This study also adds to the literature of New South urban history. Charlotte, in particular, has received a good deal of attention. In 1979, Miriam Mitchell and Edward Perzel compiled their sourcebook on the city's role during the Great War, detailing the importance of Zebulon V. Taylor as a wartime booster. Janette T. Greenwood's The Black and White Better Classes in Charlotte leaves off well before 1919, although it

${ }^{17}$ Philip S. Foner, History of the Labor in the United States: Volume VIII: Postwar Struggles, 1918-1920 (International Publishers, New York City, 1988), 102-116; Mark V. Wetherington, "Street Car City: Knoxville, Tennessee, 1876-1947," East Tennessee Historical Society (Vols. 54 and 55, 1982-1983), 70-110; James A. Burran, "Labor Conflict in Urban Appalachia: The Knoxville Streetcar Strike of 1919." Tennessee History Quarterly, Vol. 38, No. 1, (Spring 1979), 62-78; James B. Jones, Jr., "The Other Side of the "Dynamo of Dixie": Class Consciousness and Worker Solidarity in Urban Tennessee: The Chattanooga Carmen's Strikes of 1899-1917," Tennessee History Quarterly, Vol. 52, No. 2, (Summer 1993), 98-112. 
provides a good urban historical reference. She discusses the creation of Charlotte suburbs, noting the rise of future Charlotte mayor Frank R. McNinch in city politics. Currently the curator of the Levine Museum of the New South in Charlotte, Thomas W. Hanchett covers the drab yet historically compelling world of textile mill workers in Sorting out the New South City. ${ }^{18}$

No discussion of Charlotte history may be considered complete without Dan Morrill of the University of Charlotte, who has researched the horse-drawn trolleys of Charlotte and Mecklenburg County. Beginning in the 1980s, Morrill began championing historic restoration efforts in Charlotte. Morrill devoted one segment to the Charlotte strike with his electronic publication, The New South Elite in Control, although his coverage ends prematurely with the violent confrontation in Dilworth. Morrill also contributed perspectives on the strike's $75^{\text {th }}$ anniversary to the Charlotte Observer. Morrill also fought unsuccessfully to preserve the original Dilworth SPU car-barn from demolition. However, since Morrill's works are primarily focused on preservation, they tend to be more descriptive, less analytical of historical problems. ${ }^{19}$

So far, the best documented scholarly account of the Charlotte chapter has been Carol Shaw's unpublished honors thesis, "A City in Conflict: the 1919 Charlotte

\footnotetext{
${ }^{18}$ Thomas W. Hanchett, Sorting Out the New South City (Chapel Hill \& London: University of North Carolina Press, 1998), 73-4; Janette T. Greenwood, The Black and White Better Classes in Charlotte (University of North Carolina Press: Chapel Hill \& London, 1994); Miriam G. Mitchell and Edward S. Perzel, The Echo of the Bugle Call: Charlotte's Role in World War I (Charlotte: Heritage Printers, Inc., 1979), 2-7.

${ }^{19}$ Dan L. Morrill, "The Trolley Car," Charlotte Observer, 24 April 1983, 4E; The New South Elite in Control. Available from http://danandmary.com/historyofcharch10.htm, accessed 20 April 2003; "A Brief History of the Mule-drawn or Horse-drawn Streetcar System in Charlotte, North Carolina 1883-1891" (unpublished research paper, 27 November 1991); Lew Powell, "Close, But No Trolley," Charlotte Observer, 24 April 1984, 3E; “Tracking Trolleys,” Charlotte Observer, 17 April 1984, 3E; Maschal, 1E-2E.
} 
Streetcar Strike.” Shaw cites two major city newspapers, Charlotte Observer and Charlotte News, as well as Motorman and Conductor publications. She also consulted the Federal Mediation and Conciliation records, although she did not make full use of them. Lamentably, Shaw's original research never expanded beyond her 1980 honors thesis. She focuses primarily on Charlotte's urban and political history, but pays little attention to regional links. Shaw's account halts with the strike settlement, only cursorily assessing the strike's political and legal aftermath. ${ }^{20}$

In rewriting their own past, Southern Power, and its successor, Duke Power, were clearly successful. Historian Allen Tullos and journalist Richard Maschal each interviewed surviving Southern Power employees in later years. Maschal concluded that over 75 years, Duke Power waged a campaign to discourage memory of the Charlotte strike. Amalgamated Transit Union (ATU) historian Shawn Perry confessed he had been unaware of this dispute. Thus, even transportation workers themselves have become sadly ignorant about poignant chapters in their own story. ${ }^{21}$

In 1994, Dan Morrill even debated whether urban streetcar workers actually possessed a true "culture," in comparison with Carolina Piedmont mill villages. "One of the fundamental things about textile mills;" Morrill reminded the Charlotte Observer, "people lived together, worked together, went to church together. It was more than a workplace; it was a lifestyle." Morrill concluded his interview with this somewhat

${ }^{20}$ Carol Shaw, "A City in Conflict: the 1919 Charlotte Streetcar Strike" (unpublished honors thesis, University of North Carolina at Chapel Hill, 1980).

${ }^{21}$ The Charlotte Observer, 23 August 1994, 1E-2E. 
generalized assessment: “Streetcar conductors had no 'culture,' and in their defeat, left no person or institution to tell their story.",22

Between the Wheels ultimately concerns the vanished social history of motormen and conductors from the Carolina Upcountry. These workers, while relatively small in number and scope, developed their own work culture alongside those of textile laborers. While streetcar mechanics and conductors did not have company stores, mill schools, or common churches, they certainly inhabited a microcosm uniquely their own. Streetcar workers were visible representatives of the working class, with smartly uniformed conductors and dutiful motormen dealing with customer relations and public safety concerns. These ordinary men struggled against extraordinary odds in Spartanburg, Charlotte, and Columbia. Today, their way of life is gone, and the parallel world of Carolina textile mills appears to be heading the same direction, with the rise of globalism.

While labor and corporate institutions have both allowed this significant regional struggle to slip into near-oblivion, individuals still remembered their world, long after it faded from view. Allen Tullos's interviews with two streetcar workers, Loy Cloninger and Jesse B. Ashe, reveal much about their vanished world. Tullos also interviewed retired engineer Herman Wolf, a longtime Southern Power employee acquainted with the strike. Cloninger's story in particular serves as an eyewitness account of what actually happened on that blood-drenched August night. Both men recalled their careers with Southern Public Utilities, from their personal lives to their workplaces. Unmarried

${ }^{22}$ Richard Maschal, "Forgotten Night of Fear," Charlotte Observer, 23 August 1994, 1E-2E. 
streetcar men often shared lodgings, typically in boarding houses, where they shared meals together. They also played baseball and enjoyed other pastimes. ${ }^{23}$

More importantly, streetcar worker culture is preserved in several trade and labor publications, from Southern Public Utilities Magazine to Motorman and Conductor. SPU's company periodical details a vivid milieu wherein its streetcar men held competitions for job safety records, contributed poems and humorous stories, and above all, shared the happiness and sorrow of fellow employees. Motorman and Conductor lends even more insight to the overall world of streetcar workers, and their responses to post-war changes, from the adoption of one-man streetcars to Red Scare tactics in the workplace. In conclusion, Upcountry Carolina streetcar workers did not exist in a geographical or cultural vacuum. Between the Wheels is ultimately their story -- a struggle for industrial democracy as they perceived it. As Dan Morrill once said of these unsung workers, "If you don't tell their stories... they're forgotten.,"24

${ }^{23}$ Jesse B. Ashe, interview by Allen Tullos, 13 June 1980, recording, University of North Carolina at Chapel Hill, Southern Historical Collection, Louis Round Wilson Library; Loy C. Cloninger, interview by Allen Tullos, 18 June 1980, transcript, University of North Carolina at Chapel Hill, Southern Historical Collection, Louis Round Wilson Library; Herman Wolf, interview by Allen Tullos, 15 July 1980, recording, University of North Carolina at Chapel Hill, Southern Historical Collection, Louis Round Wilson Library.

${ }^{24}$ Maschal, 1E-2E. 
Chapter Two: Superpowers of the New South

Before visiting the microcosm of streetcar labor conflicts in the Carolina Piedmont, one should examine larger context of Southern Power's electrification campaign, interwoven with the development of powered textile mills across the region. James B. Duke's transition from tobacco profiteer to power-broker of the Carolina Piedmont is a tale unto itself. Across the South, municipal and inter-urban traction corporations were a logical outgrowth of the burgeoning public utility market, which derived its existence from hydro-electrical developments. As Duke's electrification projects multiplied, so grew his interests in the lucrative realms of textiles and public transportation.

After Reconstruction, South Carolina's Upcountry and North Carolina's Piedmont regions became the focus of intensive manufacturing and trade activity. Northern developers looked southward, where raw materials were plentiful, and manual labor even cheaper. But no industry proved more vital to the entire Carolina Upcountry than textile manufacture. While the region's cloth and fabric industry reached its zenith after the First World War, mills were already evident beforehand. During the 1880s, South Carolina launched pilot mills in Anderson, Greenville, and Spartanburg counties. These Upcountry county seats soon became citadels of Henry W. Grady's "New South," exemplified by Greenville's 1915 Southern Textile Exposition. North Carolina's Piedmont towns also enjoyed growth in textiles and furniture manufacturing. ${ }^{1}$

\footnotetext{
${ }^{1}$ Walter Edgar, South Carolina: a History (Columbia: University of South Carolina Press, 1998), 456-7. Essential reading on the New South begins with C. Vann Woodward, Origins of the New South: 1877-1913 (Baton Rouge: Louisiana State
} 
Local boosters - principally merchants and wealthy landowners -- were able to channel their wealth into these new ventures, becoming stockholders in these new industries. These economic and industrial advancements came with a steep price, however. According to regional historians, much of the investment capital accumulated at the expense of Piedmont farmers, whose credit flow and crop prices were controlled by the merchant classes. This situation gave rise to friction between industrialists and farmers, who came to resent urbanization and industrial progress. ${ }^{2}$

Meanwhile, rural Piedmont families were also rocked by serious agricultural downturns throughout the 1880s and 1890s, forcing them to sell their lands and move into cities and towns. According to C. Vann Woodward, ex-farmers who "almost overnight left the old farm for the new factory" were most enthusiastic recruits. This important trend began with the Piedmont Manufacturing Company in 1876, near Greenville, South Carolina. From this development, a veritable textile boom ensued in the Piedmont over the next two decades. Four mills sprung up in Mecklenburg County, North Carolina alone in the 1890s. As historian Jeanette Greenwood describes, a "string of mill villages encircled" the burgeoning city of Charlotte by 1900. "Property-less and seemingly rootless mill workers" often migrated seasonally between city, country, and mill. As in the North, some Southern mill towns were "model" villages, masking their

University Press and the University of Texas, 1951); Woodward's themes are further developed by George B. Tindall in Emergence of the New South: 1913-1945 (Baton Rouge: Louisiana State University Press and the University of Texas, 1967).

${ }^{2}$ See David Carlton, Mill and Town in South Carolina 1880-1920 (Baton Rouge and London: Louisiana State University Press, 1982); Allen Tullos, Habits of Industry, White Culture and the Transformation of the Carolina Piedmont (Chapel Hill: University of North Carolina Press, 1989), 135-6. 
drudgery behind company housing and schools. But turnover rates in these multifarious company towns exceeded 100 percent, as massive layoffs and epidemics took their toll. ${ }^{3}$ In the Carolina Piedmont, paternalistic capitalism became the rule, as textile barons sent their agents to recruit mill workers from among poor tenant farmers, with promises of better wages and lodgings. In reality, these mills represented hardship and toil for adults and children alike. As New South scholar Tom Hanchett shows, adult earnings were so meager that children as young as eight had to "help their parents" in the mills - a situation most mill owners cheerfully exploited. Some mills, particularly in South Carolina, boasted private schools for mill-worker children, but their quality and effectiveness varied considerably. Moreover, poor sanitation often cost the lives of children among the mill-towns, due to shortages of physicians and state inoculation programs. Hence, child labor became a significant cause célèbre for those reformers and muckrakers who paid attention to the New South's plight. ${ }^{4}$

North Carolina's Department of Labor published annual reports on the state's growing industrial sector throughout this period. In 1890, only 49 textile mills existed in North Carolina. By 1905, this number had grown to 287, with the majority concentrated in the Piedmont region. The period spanning 1907-08 marks the pinnacle of organized farmer activity in the Old North State. Coincidentally, James B. Duke also made rapid strides toward hydro-electric development in the Piedmont. In 1907, 52,178 employees worked for 329 North Carolina textile mills, earning a high daily wage of $\$ 2.56$, with a low of 82 cents. Knitting mill employees, numbering about 4,700 men and women,

\footnotetext{
${ }^{3}$ Janette T. Greenwood, The Black and White Better Classes in Charlotte (Chapel Hill \& London: University of North Carolina Press, 1994), 128-9; Woodward, 222.

${ }^{4}$ Thomas W. Hanchett, Sorting out the New South City (Chapel Hill \& London: University of North Carolina Press, 1998), 74; Carlton, 94-97; Tullos, 149.
} 
earned somewhat less across the board. Two in five of these employees were women, who typically earned about half the wages paid to males. Children usually brought home 60 cents per day - their exact percentage of labor went unreported. ${ }^{5}$

Mill shifts typically lasted between 10 to 12 hours, with many operators unofficially exceeding these arduous schedules. Quite a number of textile and knitting mills failed to report their actual hours of operation. So-called "stretch-outs" were grueling periods of overtime without compensation, increasing the likelihood of workplace accidents. In the Atherton Mill in Charlotte, workers often mangled their hands, and one overseer died when he became entangled in the belting apparatus. Most employers, however, turned a deaf ear toward union appeals for eight-hour workdays, or living wages. Allen Tullos documents how Protestant work ethics bolstered paternalistic Southern employers, enabling them to justify keeping their workers in check. D.A. Tompkins, owner of Atherton Mill, summed up the attitudes shared by many of his contemporaries in Charlotte and the surrounding region. He felt that "surplus time" would be "absolutely injurious" for the working class. Tompkins further asserted that employers should not give workers more money than they knew how to spend wisely. ${ }^{6}$

Workers could strive to change their environment, but those who went against the run of the mill faced dire consequences. Employers routinely discharged workers suspected of joining unions. Evictions of whole families often occurred in company

${ }^{5}$ South Carolina did not have a corresponding Department of Labor until the New Deal governorship of Olin D. Johnston in the late 1930s. (Twenty-First Report of the Department of Labor and Printing of the State of North Carolina, 1907 (Raleigh: E.M. Uzzell \& Co. State Printers and Binders, 1908), 198-212).

${ }^{6}$ Hanchett, 74, Tullos, 158-9, Carlton, 258-9; Twenty-First Report, 212-43; Dan L. Morrill, Dilworth's Early History, available from http://www.cmhpf.org/kids/neighborhoods/Dilworth-early.html; Internet, accessed 17 November 2008. 
housing complexes. Often, when frustrated mill workers could not lash out at their employers, they brawled among themselves in the streets. This violent image tended to undermine cooperation between textile workers and more highly-skilled workers, such as streetcarmen and electricians. ${ }^{7}$

Employers often capitalized on their workers' fears of outside competition from cheap immigrant labor. Violent events from the previous century also shaped views, as strikes often resulted in bloodshed. When private corporations or authority figures employed force, they were protecting property rights. Laborers who fought back were invariably characterized as radical threats against law and order. By labeling union organizers as "foreigners" and "anarchists," businessmen discouraged their employees from seeking help from labor organizations. Hence, the seeds for portraying trade unionism as a thoroughly "alien doctrine" were planted quite early in the rapidly industrializing Carolina Piedmont.

North Carolina's Labor Department interviewed employers in 1907-08 concerning the topics of foreign labor and radicalism. H.L. Beck of Thomasville, president of Norfolk \& Southern Junction Mill, opposed hiring immigrants from Italy and Eastern Europe, "where anarchy and dare-devils are bred.” L.F. Graves, SecretaryTreasurer of Flint Manufacturing in Gastonia, attacked wandering "stirrers up of strife and hardship," who sought to organize mill workers "against the men who give them employment and... honest bread." J. Hirshinger of the Charlotte Duck Clothing

\footnotetext{
${ }^{7}$ Morrill, http://www.cmhpf.org/kids/neighborhoods/Dilworth-early.html; Carol Shaw, "A City in Conflict: The 1919 Charlotte Streetcar Strike," [unpublished honors essay] (University of North Carolina at Chapel Hill, 1980), 57-59.
} 
Company sought the exclusion of "labor-disturbing, strike-causing... elements" from Central Europe, for which North Carolina has no place." ${ }^{8}$

Despite incidents of strife, Piedmont factory workers tended to side with their employers on immigration and race. If nothing else, the specters of unemployed European immigrants affected American tradesmen on a far more individual scale. Potential strikers faced the unspoken threat of being replaced by imported labor. Albert Smith of Gastonia remarked that "our people don't go to other countries hunting work, and we don't need any such people here." Smith also characterized "the majority of foreigners" as being "worse than Negroes," often leaving "their own countries by reason of crimes." J.E. Torrence of Mecklenburg Country also felt immigrants "flooding our land" were largely responsible for the high crime rates reported by newspapers. One Union County police officer, R.H. Moore of Monroe, went so far as to openly declare "ninety-five percent" of foreigners to be criminals. ${ }^{9}$

On the subject of foreign labor, European immigrants were almost as reviled as African-American laborers. Unstable European nations seemed rife with radicals, as some undoubtedly turned toward anarchism or socialism. Moreover, economic competition gave breath to religious hatreds, especially toward Catholic groups, such as Italians and Poles. That many Southern farmers squarely blamed foreign labor for their misfortunes remains an unfortunate effect of nativism commonly felt across the nation. These men also belonged to the era of trans-Atlantic ocean liners, which brought

\footnotetext{
${ }^{8}$ Twenty-First Report, 177, 181, 185.

${ }^{9}$ Twenty-First Report, 5, 104-5, 109.
} 
impoverished steerage passengers and their families over to North America. These new arrivals were not universally welcomed by most Americans. ${ }^{10}$

North Carolina farmers led the early struggle against this emergent industrial capitalism, partly as a response to urbanization and wage labor. The National Farmers Union (NFU) established a North Carolina chapter in 1908, uniting white agricultural workers and small farm-owners. Within four years, this militant NFU chapter boasted 33,688 members from 1,783 locals, becoming the "largest and most effective" labor organization in the Upper South. During its 1907-08 survey, the North Carolina Labor Department concluded that farmers in North Carolina had rallied since the downturns of decades past. The state Labor Department also interviewed the Piedmont's industrial workers, primarily mill hands, who desired the same union representation enjoyed by farmers. One mill worker, J.A. Thompson of Montgomery County, believed North Carolina "farmers should be organized, as well as other trades and professions."11

Despite the Piedmont's overall reputation for anti-unionism, the NFU organized effective resistance against textile mill operators, whose recruitment efforts depleted white tenant populations. This change forced remaining farm-owners to consider hiring black sharecroppers or European immigrants. W.F. Logan of King's Mountain (on the South Carolina border) voiced concerns shared by many regional farmers. Logan asserted: "We are getting our state organized as fast as we can, as farmers, so that we may get more profit out of farming... than we have in the past." In particular, Logan

\footnotetext{
${ }^{10}$ See John Higham, Strangers in the Land: Patterns of American Nativism 1860-1925 (Atheneum Press, New York City, 1963).

${ }^{11}$ Dewey Grantham, Southern Progressivism: The Reconciliation of Progress and Tradition (University of Tennessee Press, Knoxville, 1983), 329-32; Robert F. Durden, Bold Entrepreneur: A Life of James B. Duke (Durham, NC: Carolina Academic Press, 2003), 39-55; Twenty-First Report, 10, 104-9.
} 
blamed textile mills, with promises of year-round employment, for a recent farming decline: "The farm could be made to pay just as any other work if the people would only stick together... the Farmers' Union will teach them," he remarked. Another North Carolina farmer, Avery G. Higgins of Belwood, put it another way: "While the mills are a great benefit in an industrial way, they are filling graves with consumptive victims." 12

W.F. Logan and his fellow farmers also came to view the NFU as a political instrument to prevent urban industrialism - and cheap mill labor -- from eclipsing their own world. As Logan also observed, "Immigrants are giving trouble in some sections now; so we want to keep them out." G.F. Hambright - also from King's Mountain -- put it even more bluntly: "I would rather my land lay out than to be worked by Negroes and foreigners." C.A. Ridenour of Stanly County told state authorities "we don't need anarchists and hoboes." James Wilson of Mecklenburg County predicted that "hiring the scum of the world" for cheap labor would create a "hornet's nest" in the countryside. Some regional farmers were a little more discerning toward foreign labor. B.F. Carpenter of Gaston County noted that the depopulation of tenant farmers lured to cotton mills opened the door to hiring "law-abiding" Germans. But Carpenter would employ "no Southern Italians," owing to their alleged Mafia and Black Hand connections." 13

By 1916, the year before America entered World War I, the Charlotte Piedmont region experienced changes that hastened the general decline of state agriculture. Long winter delayed the planting season, causing many hands to seek other work in the spring. According to state records, 89 counties reported a scarcity of farm labor during the summer. Except for Mecklenburg, all Piedmont North Carolina counties reported a

\footnotetext{
${ }^{12}$ Twenty-First Report, 42-43.

${ }^{13}$ Twenty-First Report, 49, 65-66, 79.
} 
dearth of overall labor. Charlotte-Gastonia's urban industrial powerbase offered relatively higher wages, offering better wages and housing to more families. Mecklenburg men were paid \$1.25 per day, while Gaston County reported its highest daily wage at $\$ 1.30$. While these were not North Carolina's highest wages at the time, Charlotte-Gastonia's daily wages were uniformly high in comparison with most of the Piedmont region, which often dipped below one dollar. ${ }^{14}$

Further setbacks during the summer of 1916 hastened the demise of agriculture in the Piedmont. Beginning on July 15, two days of disastrous flooding wiped out acreage across the Piedmont and Western North Carolina. North Carolina Governor Locke Craig, hailing from the mountains, responded quickly to the crisis. Millions of dollars were lost, even as engineers sought to rebuild hydro-electric plants in the Blue Ridge Mountains. As these men worked to rebuild Falls Branch, their laconic employer muttered "I'll be dinged," pondering the flood's impact on his wide-ranging Piedmont Carolina interests. ${ }^{15}$

One of the Piedmont's most influential figures, James Buchanan Duke, made his initial mark through agriculture. Together with his father and elder brother, Duke entered the post-Civil War market with ambition, if not perspicacity. Demand for Southern tobacco rose in the Gilded Age, aided by mass production of cigarettes via the Bonsack rolling machine. This technological advance enabled James B. Duke (1856-1925) to dominate the global market of the smoking industry from 1890 to 1910 . Duke's sphere of influence soon extended overseas toward Great Britain, Australia and even Japan.

\footnotetext{
${ }^{14}$ Thirtieth Reports of the Department of Labor and Printing of the State of North Carolina, 1916. (Raleigh: Edwards \& Broughton Printers, 1917), 16-23.

${ }^{15}$ William S. Powell, editor, Dictionary of North Carolina Biography, Volume 1, (Chapel Hill: University of North Carolina Press, 1979); Durden, 133-35.
} 
Originally from Durham, North Carolina, Duke quickly became an absentee owner in 1885, with a Fifth Avenue mansion in New York City, as well as a posh New Jersey farm estate. Across the Piedmont, Duke's tobacco empire also controlled hundreds of tenant farms, marking the advent of what today we would call "agri-business."

But North Carolina and federal authorities quickly focused on Duke's American Tobacco Company, with over thirty thousand laborers. In 1901, Duke appeared before the U.S. Industrial Commission to testify in defense of his company's practices. One commissioner, John M. Farquhar, brought up Duke's refusal to meet with the National Tobacco Workers Association on two occasions. Moreover, Duke's opposition toward the chiefly Democratic National Farmers' Union is fully documented. ${ }^{17}$

Victory came for agrarian reformers in 1911, with the U.S. Supreme Court's dissolution of Duke's American Tobacco Company. Duke still retained his British tobacco conglomerate, and continued to own stock in Southern tobacco. However, his vast domestic empire had suffered a severe blow. As a Republican, Duke chiefly blamed the reform wing of the Democratic Party, with its endorsements of regulation and labor unionism. He especially disapproved of Woodrow Wilson's "New Freedom” platform. Duke warned progressive lawmakers: "You are pulling down the pillars of our business temples." He also once remarked to a sympathetic B.C. Forbes that wealthy men were admired everywhere except the United States, where success had become a crime. ${ }^{18}$

\footnotetext{
${ }^{16}$ Durden, 75.
}

${ }^{17}$ Report of the Industrial Commission on Trusts and Industrial Combination, Vol. 13 (Washington D.C.: Government Printing Office, 1901), 317-332.

${ }^{18}$ J.W. Jenkins, James B. Duke: Master Builder (Spartanburg, South Carolina: The Reprint Company, 1927), 218-30; Durden, 67-84, 102-3; Grantham, 144, 331. See also Bertie Charles Forbes, The Men Who Are Making America (New York: B.C. Forbes Publishing Company, Inc., 1917). 
Duke's acquisitive nature has been downplayed through recent scholarship, in light of his charitable work. Duke's many millions enabled him to donate thousands to charities he felt worthwhile, such as Billy Sunday's Protestant ministry. While he was consistently paternalistic, Duke nevertheless took a charitable interest in the welfare of North Carolinians, donating thousands to build hospitals and orphanages in Charlotte and Durham. Many of these projects benefited African-Americans living in the Piedmont. Allen Tullos has aptly described James Duke's character as a formidable combination of "hidebound industriousness, utilitarian ruthlessness, and fierce practicality." 19

Well before American Tobacco's defeat in the U.S. Supreme Court, James B. Duke and his brother, Ben Duke, had already sensed the possibility of wealth through the burgeoning electric-power industry needed to energize the Piedmont's textile mills. In 1892, the Dukes invested capital in Erwin Mills, managed in Durham, North Carolina, by William A. Erwin, also from a significant North Carolina industrial family. With Ben Duke as the formal owner, Erwin Mills later expanded to include four outlets, plus a fabric bleachery, according 1919 labor statistics. ${ }^{20}$

For the Dukes, textile mill ownership began as a side-venture, bearing unexpected fruit in later years with the advent of hydro-electricity. Such experiments were already underway in the Piedmont. In 1894, Columbia Mills in South Carolina, popularly called the "Duck Mill," successfully integrated 17 motors (at 1105 horsepower), deriving the region's first alternative current from nearby Congaree River. Another major Piedmont

\footnotetext{
${ }^{19}$ Southern Power hired blacks for some of its more dangerous jobs, such as gas line construction. Southern Public Utilities also employed black motormen and conductors for segregated neighborhoods. (J.W. Jenkins, James B. Duke: Master Builder, Spartanburg, South Carolina: The Reprint Company, 1927, 244-50; Southern Public Utilities Magazine, Vol. 5, No. 5, October 1919, 23; Durden, 75, 139; Tullos, 161-66).

${ }^{20}$ Thirty-Second Report, 108.
} 
waterway, the Saluda, brought electrification to Upper South Carolina, while the Seneca River helped to power the nearby mill-town of Anderson as early as 1898. More importantly, the Catawba River, flowing past Charlotte, provided an ideal location for entrepreneurs capitalizing on regional growth. ${ }^{21}$

After 1895, Dr. Walker Gill Wylie (1848-1923) of Chester, South Carolina, began investing in new hydro-electric projects on the Catawba River. Wylie's Upcountry experiments capped off a lengthy career of intellectual and professional distinctions. Graduating from the University of South Carolina at twenty, Wylie moved to New York's Bellevue Hospital Medical College, graduating in 1871. Dr. Wylie went overseas to study European medical practices in the wake of the Franco-Prussian War, and his recommendations prompted Bellevue Medical College to open the nation's first nursing school for women. Following an illustrious career as a lecturer in gynecology, Wylie returned to his native state during the 1890 s, where he became an advocate and booster for hydro-electrical power in the South Carolina Upcountry. Wylie's first documented venture at Portman Shoals in 1895 developed about 1,800 horsepower of electricity, sufficient to power a nearby cotton mill in Anderson, South Carolina ${ }^{22}$

Impressed with the results at Portman Shoals, Gill Wylie subsequently enlisted his brother, Dr. R.H. Wylie, to back further projects along the Catawba River. By 1900, the Wylie brothers had established the Catawba Power Company with Gill Wylie as sitting company president. Despite flooding and personnel changes, Catawba Power Company

${ }^{21}$ Joseph Maynor, Duke Power: the First Seventy-Five Years. (Charlotte: Duke Power Inc., 1979), 11-13, 21; Fetters, Thomas T. and Peter W. Swanson. Piedmont \& Northern: The Great Electric System of the South. (San Marino, CA: Golden West Books, 1976), 10; Durden, 120-21.

${ }^{22}$ Maynor, 11-13, 21; Durden, 120-21. 
successfully completed its first dam in 1903, located at India Hook Shoals. Coupled with a network of transmission lines, Wylie's ambitious project would bring electricity to Charlotte and its satellite towns, at an unprecedented rate of efficiency. ${ }^{23}$

The Dukes, like Wylie, recognized the potential of such innovation. On behalf of the Duke family, William Erwin began mapping the upper Catawba River for likely dam sites in 1899. By 1901, Erwin had purchased the Great Falls environs for about $\$ 90,000$. Erwin deemed this location less vulnerable to flooding, as the river seldom rose above eleven feet. The Dukes secured their claim to Great Falls soon afterward, establishing the generic-sounding American Development Company. ${ }^{24}$

Chief catalyst behind Catawba Power's success, engineer William States Lee, Jr. began his career shortly after graduating from the Citadel in 1894. Lee served as resident dam engineer for two hydro-electric projects, at Portman Shoals and Columbus, Georgia. Soon afterward, W.S. Lee came to the attention of Dr. W. Gill Wylie, who enlisted his talents. Wylie later explained to Lee that successfully building the Catawba plant would make his reputation as an engineer. Wylie's scheme involved building hydro-electric dams along the Catawba, utilizing a large part of the 700 -foot fall which occurred along the river's course of 130 miles, from Camden, South Carolina to Hickory, North Carolina. Moreover, the Catawba River became the Wateree River in South Carolina, further linking both regions. This situation, in effect, placed the Wylies in competition against the Dukes' American Development Company, situated at Great Falls on the Catawba River. ${ }^{25}$

\footnotetext{
${ }^{23}$ Maynor, 11-13, 21.

${ }^{24}$ Durden, 120.

${ }^{25}$ Maynor, 13; Durden, 121.
} 
Wylie sensed an opportunity for a "superpower system," and began assiduously courting the Dukes as co-sponsors for a merger. While Benjamin Duke had earlier given a modest boost to Wylie's India Shoals project, his wealthier brother remained aloof toward the venture. Duke later admitted his reluctance, based on perceptions that the American Development Company did not hold the same opportunity for wealth as had the American Tobacco Company. As biographer Robert Durden argues, James B. Duke "never invested his money capriciously." In late 1904, Wylie's medical profession finally broke the ice, when "Buck" Duke sought the doctor's advice on his brother's recommendation. While treating Duke's foot inflammation, Wylie unfolded Catawba Power's capital problems to the skeptical entrepreneur. Wylie's earnest vision, perhaps aided by W.S. Lee's growing reputation as an engineer, convinced Duke to reconsider. According to Wylie, Duke requested "that man, Lee" to bring all their plans, and promised "maybe I will go in with you." Herein lay the seeds of the great Southern Power Company, later renamed Duke Power, and known today as Duke Energy. ${ }^{26}$

Using Catawba Power Company as collateral, Duke raised $\$ 2$ million for this new joint venture in 1905. Charlotte became the company's central headquarters, owing to the city's reliance on textile mills since 1881. Within 18 months, Southern Power completed its first dam at Great Falls, South Carolina, yielding 40,000 horsepower. Within four years, William S. Lee oversaw two more successful dams, at Rocky Creek and Ninety-Nine Islands, on the Broad River. By 1909, Southern Power's total output exceeded 80,000 horsepower, bringing cheap electricity to the region's growing towns. ${ }^{27}$

${ }^{26}$ Charlotte: a Guide to the Queen City of North Carolina, Edwin Bjorkman, ed., (Charlotte: News Printing House, 1939), 30; Maynor, 13, Durden, 119-20.

${ }^{27}$ Maynor, 13; Bjorkman, 30. 
Just how much impact did Southern Power exert on North Carolina by the close of World War One? According to one member of North Carolina's Geological and Economic Survey, the war decade boosted Tarheel State industry from twenty-third to tenth place. Crop value also skyrocketed from nineteenth to fourth place. With this unheralded growth also came a "tremendous demand for power," largely satisfied by "the creation of a gigantic water-power business." According to Thorndike Saville, University of North Carolina professor of hydraulic engineering, no region in America "east of the Rockies" enjoyed such access to electricity. ${ }^{28}$

While it would be an overstatement to attribute the Carolina Piedmont's expansion solely to Southern Power, its hydro-electrical developments certainly contributed toward new industry and population growth. Relatively cheap electric power undoubtedly improved the quality of life for those living in areas within Southern Power's ever-widening sphere of influence. But as a result, the Piedmont region experienced a surge in mill-building, with commensurate city growth. Southern Power greatly accelerated these trends toward urbanization and expansion, following its incorporation in 1905.

The primary market for Southern Power lay with textile mills. According to the 1919-20 North Carolina Department of Labor, the primary energy source for North Carolina businesses remained steam power. By early 1921, the Tarheel State totaled 3,182 factories and mills powered by various means, yet electricity had enjoyed a steady increase in North Carolina since World War I. 1,023 of these factories used electricity exclusively, while 148 others used electricity in conjunction with another form of energy.

\footnotetext{
${ }^{28}$ Maynor, 13; Bjorkman, 30.
} 
More importantly, a high percentage of knitting and cotton mills relied on electricity to the exclusion of all other energy sources. 106 of 169 knitting mills and 184 of 377 cotton mills reported using only electricity for their business activity during 1919-20.

Moreover, 46 cotton mills had been established within two years. ${ }^{29}$

According to Federal and North Carolina Geological surveys, both Carolinas ranked highest in actual percentage of power derived from hydro-electric operations. Whereas South Carolina's dams yielded far power more in 1907 (the first data year), North Carolina had begun to overtake her sister state by 1919. Statistics place North Carolina's power percentage at 93.1 percent, with South Carolina at 92.4. Georgia and Virginia came in at 82.3 and 38.9 percent respectively. ${ }^{30}$

By 1920, Southern Power accounted for nearly 70 percent of public utility electricity in North Carolina alone. It was rivaled only by the Aluminum Company of America (ALCOA), owner of Tallasee Power Company, which yielded 113,000 out of the state's total of 360,000 horsepower. In comparison, Southern Power's Bridgewater and Lookout Shoals dams brought only 63,000 horsepower, about one-third of Alcoa's quotient. However, it should be noted that much of Tallasee's power went toward their ore extraction operations in the Carolinas. Unlike Southern Power's network, little of this electricity affected the urban development of the Carolinas. ${ }^{31}$

Without question, Duke's Southern Power played a leading role in North Carolina's great industrial leap forward, while South Carolina's foothills also witnessed a

${ }^{29}$ Thirty-Second Report, 77, 102-3, 162-3.

${ }^{30}$ Ibid.

${ }^{31}$ Thirty-Second Report, 657-660. 
dramatic influx of capital and jobs. Yet, what motivated James Buchanan Duke, one of the foremost exponents of the New South? Unsurprisingly, Southern Power and Duke Power sources characterize their founder as altruistic, verging on the beatific. Dismissing the "New South" creed as an "incantatory phrase so beloved by regional boosters and politicians," Robert Durden of Duke University even goes so far as to portray his subject as an almost transcendental figure, storing up his heavenly estate. Durden states his case thus: "money-making, per se, was not Duke's prime purpose in his zealous effort to build up and protect the power company. Instead, Duke sought the "industrialization of the Piedmont Carolinas" largely out of public spirit, while "providing a stable, dependable source-base for a perpetual charitable trust." ${ }^{32}$

One must concede Duke's endowment as an overall blessing to the Carolinas, but businessmen cannot create such a "perpetual charitable trust" without first having built their business empires with iron resolve. At the heart of Duke's vision indeed lay a "ruthless utilitarianism," to quote Allen Tullos. Most of the Duke Endowment's philanthropy went into effect many years after his unexpected death in 1925 . To accept Robert Durden's uncritical portrait of James B. Duke, one would have to view this industrial titan as a modern-day Prometheus who sacrificed himself to bring divine sparks of electricity to his home state. Durden's biography presents one interpretation of James B. Duke, but its origins from Duke University and its conservative, pro-business bias should also be considered. ${ }^{33}$

It is almost tempting to view Duke as a reformed monopolist. His ostensible goal, to "pull the South out of the economic doldrums" seems more humanitarian than

\footnotetext{
${ }^{32}$ Durden, 85, 119; Maynor, 67.

${ }^{33}$ Durden, 153; Tullos, 162.
} 
cornering the tobacco market. Duke personally doubted his hydro-electricity investments would turn out as much profit as his erstwhile tobacco empire. But even as Southern Power gradually won over city planners and farmers to their electrification campaign, its other Piedmont interests grew apace. Southern Power (and later, Southern Public Utilities) employed cheaper rates to undercut rival power companies throughout the region, with resultant controversy in the North Carolina Corporation Commission. Throughout the 1920s, Southern Power's "rate war" against business regulation spilled over into the political sphere, with great financial and personal cost to James B. Duke. ${ }^{34}$

Governing from afar in New Jersey, James B. Duke soon found his earlier reservations about low profits were ill-founded. As Duke's earliest biographer, J.W. Jenkins, described him, "mass production, volume, [and] giving the largest possible values for the money, were his hobbies." Controlling nearly all power-plants along the major Piedmont waterways eventually led to Southern Power's monopoly of electricity. As Southern Power expanded in the first decades of the Twentieth century, more textile mills became reliant on Duke's utility services. Furthermore, incorporated towns and mill-villages were also attracted to Southern Power's affordable rates and record of high reliability. According to company sources, Duke initially "took a dim view of expanding electrical service beyond the industrial and municipal markets," which had been his initial targets. Mill-villages were seen as "more of an irritant," while rural dwellers were unflatteringly portrayed as superstitious rustics who mistrusted electricity. ${ }^{35}$

Moreover, as demand grew for Southern Power's services, Duke began to see the advantages of expanding beyond his original "Mill a Mile" strategy. Duke's widespread

\footnotetext{
${ }^{34}$ Maynor, 67-68, Durden, 159-66.

${ }^{35}$ Maynor, 67; Jenkins, 169.
} 
gains in Charlotte convinced him to delegate management of utility services and public transportation to a subsidiary company. In 1915, Duke created Southern Public Utilities (SPU) in Charlotte to handle contracts with textile mills, townships, and individuals. His close friend, Zebulon V. Taylor, became the first SPU president. While Southern Power continued to build power plants and dams, Southern Public Utilities acted as the intermediary, controlling transmission lines to surrounding towns, such as Salisbury. This expanding Piedmont town adopted a new SPU franchise in April 1919. Newer textile manufacturers, such as Belbros Mills, a modest Charlotte yarn mill of 3,700 spindles and 50 employees, also entered into power contracts with SPU. These two utility contracts are all that remain extant of Southern Public Utilities business correspondence in the Duke Energy Archives. ${ }^{36}$

Southern Power contracts with textile mills had brought Duke increased influence as a shareholder in this source of wealth, especially in South Carolina's Upcountry. Herman Wolf, a retired Southern Power engineer, provided some insight into Duke's business practices. Wolf began working for Southern Power in 1916, at age twenty. The young maintenance technician helped rebuild Lookout Shoals substation after a serious river flood hit the Catawba region. Following this successful project, Wolf came to "Buck" Duke's attention, receiving more responsibility. During his travels across the Piedmont, Wolf often assisted in the electrification of North Carolina textile mills, installing generators. Wolf also recalled Southern Power's policy of loaning the mills money to purchase these generators, while buying up their company stocks. "Many

${ }^{36}$ Charles J. Burkholder, franchise agreement with Mayor and Board of Aldermen, Salisbury, North Carolina, 29 April 1919, Duke Energy Library and Archives; Southern Power Company and Southern Public Utilities Co, contract with Belbros Mills Inc., 1 June 1919, Duke Energy Library and Archives; Thirty-Second Report, 130, 145. 
textile mills were partially owned by Mr. Duke," Wolf asserted. In this fashion, Southern Power built a North Carolina plant nearly every year, beginning in $1908 .{ }^{37}$

In his 1980 interview, Herman Wolf also stressed the selling points of Southern Power, while giving substance to his late employer's philanthropic image. Duke's power rates for cotton mills were "low and attractive," owing to the fact that electricity was onethird cheaper than steam power. In fact, Southern Power's rates were so "low and attractive," it is unsurprising that North Carolina's state regulators on the Corporation Commission sought to prevent Duke from under-selling his competitors in the utilities market. Wolf also maintained that Southern Power did not actually begin to show dividends until Duke established his endowment in 1924. "Mr. Duke paid his own costs for maintenance, and even used his own office space for a bedroom," Wolf recalled. Certainly, Duke's legendary thrift has some basis in reality. However, his personal abstinence did not discourage the Duke family from purchasing "White Oaks" from his business partner, Zebulon Vance Taylor. Duke later renamed the Myers Park manor house "Lynnwood," residing there whenever conducting business in Charlotte. ${ }^{38}$

Another Duke confidante, Dr. Bennette Eugene Geer (1873-1964) brought new investment opportunities in the South Carolina Upcountry. Graduating the University of Michigan, Ben Geer served as a professor of literature at Furman University until 1911. Thereafter, Geer chose to assist his ailing brother, John M. Geer, in the management of his considerable South Carolina textile business. Before his elder brother's death in

\footnotetext{
${ }^{37}$ Herman Wolf, interview by Allen Tullos, 15 July 1980, recording, University of North Carolina at Chapel Hill, Southern Historical Collection, Louis Round Wilson Library.

${ }^{38}$ Historical Statement on the James B. Duke House, http://www.cmhpf.org/surveys\&rduke.html; Internet, accessed 5 December 2008; Hanchett, 178-9; Wolf interview.
} 
1919, Ben Geer had taken over several manufacturing sites, including the Westervelt (later Judson) Mill. Westervelt was the first Southern mill to handle rayon and silk as well as cotton. More importantly, Westervelt's primary stockholders included James B. Duke, who quickly took a shine to the learned Geer. ${ }^{39}$

Under Duke's business guidance, Geer established Southern Bleachery \& Print Works (Taylors, South Carolina), Southern Worsted Mills (Paris, South Carolina), and Southern Weaving Company (Greenville, South Carolina). Geer also built the Pacific Mills in Spartanburg County, which relied upon Southern Power's Lyman power-plant. ${ }^{40}$ Duke's assistance to Ben Geer sometimes went beyond advice. At one point, Geer owned the American Bank \& Trust of Greenville, which lost $\$ 150,000$ during the early 1920s. According to Geer's biographer, the mismanagement arose from the bank's vicepresident. Duke bailed out Geer for $\$ 100,000$, and the owner made up the difference from his own funds. In 1922, Duke also agreed to underwrite $\$ 250,000$ for Geer's proposed fabrics plant in Greenville, manufacturing auto brake linings and webbing. Incidentally, all Geer's factories were located along Duke's personal electric railway, the Piedmont \& Northern, which Geer eventually joined as associate director. ${ }^{41}$

Their lifelong partnership also placed Geer on the Duke Endowment's Board of Trustees in 1924. Duke's grants also proved instrumental in saving Geer's beloved Furman University from bankruptcy. Yet, Ben Geer was a formidable person in his own right. During the First World War, Geer advocated a national organization for mutual protection against business regulation. This lobbyist group became known as the "Cotton

\footnotetext{
${ }^{39}$ L. M. Glenn, Bennette Eugene Geer: a Biographical Sketch (Spartanburg, South Carolina: Keys Printing Company, 1956), 17-19.

${ }^{40}$ Glenn, 29-33.

${ }^{41}$ Glenn, 29-33.
} 
Textile Institute," involving both Northern and Southern mill owners. Geer also served as South Carolina's wartime fuel administrator. ${ }^{42}$

On balance, Southern Power's "Mill-a-Mile" concept fulfilled the requirements for entrepreneurialism. Duke did not stint himself on investing business capital, as evidenced by his quiet expansion into South Carolina. Exchanging Southern Power's resources for partial ownership appears to have been his overall strategy, whether it involved the Carolina Piedmont or the wilds of Quebec - his most ambitious feat of electrification after World War I. However, relatively few textile mills actually boasted Duke family ownership. According to 1919-20 statistics, Benjamin N. Duke still owned Erwin Cotton Mills (founded in 1892), numbering four outlets plus a separate bleachery. By contrast, James B. Duke was not listed by North Carolina as a principal owner of a single mill. Being a "silent partner" in Carolina textile markets enhanced Duke's superpower strategy, while preserving his image as a selfless philanthropist."43

Thus, despite the brief flurry of Federal and state reforms designed to curtail monopoly, James B. Duke's superpower campaign managed to flourish through the Wilson administration largely unhindered by Progressivism. Democratic opposition in North Carolina, led by Democratic editor Josephus Daniels, could not repeat its success against the American Tobacco Company. As early as 1912, Duke began speculating on a Canadian hydro-electrical project on the Saguenay River, in Quebec Province. For several years, liberal resistance in Ottawa blocked Duke from diverting hydro-electrical power across the Canadian border to the United States. ${ }^{44}$

\footnotetext{
${ }^{42}$ Glenn, 31-33; 38-41.

43 Thirty-Second Report, 108.

${ }^{44}$ Durden, 145-52
} 
However, Canada's severe job loss and stagnant post-war economy soon brought a change in their government. In 1922, James B. Duke received permission from the new Conservative ministry to complete his Isle Maligne project. This feat required the building of a separate railroad to supply the construction sites. Duke's most ambitious project eventually resulted in joint partnerships with such American business luminaries as future Treasurer Andrew Mellon and Alcoa's Arthur Vining Davis. Moreover, an investment deal for Isle Maligne created for Duke a one-ninth stake in Alcoa's fortunes. ${ }^{45}$

By the end of World War I, declining New England textile mills began relocating to the Carolinas, chiefly the South Carolina Upcountry. These businesses were attracted by large-scale developments of hydro-electrical power, further enhancing the region's New South reputation. Furthermore, a weak trade union presence in the Piedmont meant more control over labor sources. South Carolina cities such as Columbia and Spartanburg had grown steadily during the First World War. Spartanburg expanded from a population of 17,517 (1910) to 22,638 (1920), while the Palmetto State's capital leapt from 26,319 to 37,544 during the same time-span. The post-war influx of Northern textile mills into the South Carolina Upcountry counted for much of this expansion. ${ }^{46}$

Duke stated his sympathy for fellow businessmen in New England, and believed his Quebec project would also benefit textile mills south of the border, especially in Massachusetts. Herman Wolf phrased it this way: "If [Mr. Duke] could replicate the success of Southern Power in New England, then they could keep their mills.” While

\footnotetext{
${ }^{45}$ Wolf interview.

${ }^{46}$ David Carlton, Mill and Town in South Carolina 1880-1920 (Louisiana State University Press, Baton Rouge and London, 1982), 251-9; P.H. Norcross, Spartanburg, South Carolina Report on Water Supply (Atlanta: Foote and Davies Company, 1924), 610.
} 
Duke's efforts to bring cheaper power to New England received praise for its "public spirit," one must also concede the possibility of ulterior motive. Keeping Northern mills from North Carolina also blocked unwanted competition for Duke's own widening empire. Despite the possibility of competition, Duke nevertheless profited from those Northern interests he could not persuade to remain in New England. Duke's superpower strategy also harnessed much of upper South Carolina's business capital, through a continuance of his "Mill-a-Mile" program, as well as Southern Power's strategic developments of the Piedmont's transportation system. ${ }^{47}$

James Duke's Piedmont transportation interests developed alongside his plans for regional electrification. Duke's idea took shape with his famous Piedmont \& Northern electric railway, but even before this achievement, his Southern Power Corporation had taken over several urban traction companies suffering financial decline in the so-called "Roosevelt Recession" of 1907-08. These assets included North Carolina streetcar lines in Gastonia, as well as South Carolina investments in Anderson and Spartanburg. ${ }^{48}$

Through lucrative partnerships, James B. Duke rebuilt his business empire after losing much of his tobacco monopoly. These corporate alliances proved beneficial in the long run. Partnerships with powerful interests such as Alcoa permitted Duke to enjoy great financial influence without entangling himself in further Federal anti-trust cases. Moreover, local alliances with regional businessmen in Piedmont cities built powerful support bases in the Carolinas. Duke's allies embarked on numerous "good will" tours

\footnotetext{
${ }^{47}$ Carlton, 251-9; Norcross, 6-10; Wolf interview.

${ }^{48}$ Thomas T. Fetters, Palmetto Traction (Forty Fort, PA: Harold E. Cox, 1978), 96101.
} 
across the Carolina Piedmont to garner stockholders for Southern Power's transportation experiment, the Piedmont \& Northern electric railroad. ${ }^{49}$

This ambitious project, designed to compete with the juggernaut Southern Railway, began in 1909 with a proposal from William States Lee, now the vice-president of Southern Power \& Utilities. As Duke absorbed rivals such as South Carolina Power, Light, and Railway, the brilliant engineer saw an opportunity to consolidate these gains by linking the major Piedmont towns via an inter-urban railway system. "Buck" Duke enthusiastically supported Lee's plan, which went into effect in 1910. North Carolina chartered the Piedmont Traction Company on 8 January 1910, and South Carolina approved the much larger Greenville, Spartanburg, and Anderson Railway two months later. Piedmont Traction spanned 21 miles from Charlotte to Gastonia, while its South Carolina counterpart extended 98 miles from Greenville to Spartanburg. These two subsidiary corporations linked up at the Carolina borders in $1912 .^{50}$

Within a few years of its completion, the Piedmont \& Northern enjoyed so much success that extensions were suggested by promoters. Duke favored an Atlanta station, while other speculators spoke of a terminal in Raleigh, linking the capital city to Southern Power's Charlotte headquarters. However, these ideas never came to fruition. In time, however, wartime demands for textiles resulted in the Piedmont \& Northern Railway's expanded freight service to mill towns, such as Gastonia and Belmont Junction. ${ }^{51}$

\footnotetext{
${ }^{49}$ Thomas T. Fetters and Peter W. Swanson, Piedmont \& Northern: The Great Electric System of the South (San Marino, CA: Golden West Books, 1976), 10-11.

${ }^{50}$ Fetters and Swanson, 11-12; Fetters, Palmetto Traction, 96-101.

${ }^{51}$ Fetters and Swanson, 30-33; Emory Wister, interview by Edward Perzel, 23 May 1979, transcript, Special Collections, J. Murrey Atkins Library, University of North Carolina at Charlotte.
} 
Viewing the extensive company literature and popular history on the Piedmont \& Northern Railway, readers might be led to believe that Duke's trolley investments were mere afterthoughts. While Duke's electric railway certainly ranks as one of his greatest achievements, at least one urban historian has speculated that Southern Power's 1910 acquisition of Charlotte's streetcar lines may have encouraged Duke's construction of the Piedmont \& Northern Railway. In any case, Duke solidified his control over the rapidly expanding "Queen City" of North Carolina, which boasted a 1910 population of 34,014. Just before World War I, Mecklenburg County's overall population measured close to fifty thousand. By 1920, Charlotte had blossomed into a large municipality of 46,338. ${ }^{52}$ However, James Duke and Southern Power cannot historically claim full credit for Charlotte's staggering growth, or its suburban development. In 1890, Edward D. Latta first proposed electric trolleys to replace Charlotte's antiquated horse-drawn cars. Originally from South Carolina, Edward Latta resided primarily in New York City, where he witnessed the development of "streetcar suburbs." For almost three decades, Latta's Charlotte Consolidated Construction Company (known locally as the "Four C's") played a role in transforming the Queen City. Many businessmen in Charlotte supported Latta, anticipating that a modern streetcar suburb would attract workers to a proposed textile mill, D.A. Tompkins' Atherton Mill, scheduled to begin operation in $1893 .^{53}$

${ }^{52}$ Leake Carraway, Queen Charlotte: The Hydro Electric Centre (Greater Charlotte Club, Charlotte, North Carolina, 1913), 1; W. Hugh Harkey, More Tales from the Hornet's Nest (Charlotte: Hornet's Nest Productions, 1992), 68-69; Fetters and Swanson, 10-11; Bjorkman, 30.

${ }^{53}$ According to Dan Morrill, Latta's partners included Mayor F.B. McDowell, suggesting a degree of favoritism shown to Latta's company. (Dan Morrill, Dilworth Neighborhood Guide, http://www.cmhpf.org/kids/neighborhoods/Dilworth-early.html, accessed 11 December 2008; Dan Morrill, “A Brief History of the Mule-drawn or Horse- 
To capitalize on Atherton Mill's eventual construction, Edward Dilworth Latta planned and developed his model streetcar suburb, named Dilworth in honor of its creator. Dilworth received an early boost from none other than Thomas Edison, who visited Latta's Charlotte residence in late 1890. Edison agreed to invest in Dilworth's construction, providing an electric distribution system to enable Charlotte's first electric streetcars to begin service as early as May $18,1891 .^{54}$

Throughout 1892-93, Dilworth boosters openly courted middle-class residents. Edward Latta's sales pitch stated: "Buy a house with your rent money." However, Dilworth's development coincided with the nation's financial plunge, as well as the Homestead and Pullman Strikes. Dilworth's mainstay instead became white urban industrial workers, living in cheaply-constructed quarters purchased through Latta's rental and loan agency. Moreover, displaced agricultural families were increasingly drawn to Atherton Mill's proximity, while the new Charlotte Street Railway provided convenient transportation to nearby amusement parks. Thus, Dilworth soon became a tangled urban forest of tenements and worker housing on the fringes of textile mills, interspersed with a smattering of middle-class neighborhoods. ${ }^{55}$

After Dilworth's completion, the Charlotte Consolidated Construction Company went on to construct streetcar connections and housing developments to accommodate further population growth after 1900. These new streetcar suburbs included Piedmont

drawn Streetcar System in Charlotte, North Carolina 1883-1891," research paper, 27 November 1991).

${ }^{54}$ Dilworth became the Eighth Ward of Charlotte in 1907. ("Thomas Edison's Firm Installed Trolley to Dilworth," Charlotte Observer, 27 June 1982, Special Advertising Section 1; Joseph Goodpasture, "A Lightbulb Moment," Charlotte Magazine (Vol. 6, No. 2), February 2001, 10.)

${ }^{55}$ Morrill, Dilworth Neighborhood Guide; http://landmarkscommission.org/S\&RR/HelmsBell.html Accessed 17 February 2009; 
Park and Elizabeth Heights (both completed in 1902), as well as the upscale black community of Biddleville (finished in 1903). By 1909, Charlotte Street Railway lines measured fifteen track miles, serving much of downtown Charlotte. Furthermore, new textile mills began operations all across Mecklenburg County, creating new suburbs at Belmont, Highland Park, Atherton, and Chadwick. ${ }^{56}$

For nearly two decades, Edward Dilworth Latta basked in the Queen City's gratitude. Charlotte's Board of Aldermen granted favorable public utility contracts to the Four C's, enabling Latta's virtual monopoly over the city's gas and electric power. As late as 1906, one Charlotte publication lionized its city's premier developer for his "broad ideas and progressiveness." However, the devoutly conservative Latta lacked any true Progressive inclinations. Throughout his career, Latta showed little compassion for the new factory class who lived in his suburbs. During the height of his economic and political power, Latta openly stated that "benevolence has no rightful place in any real estate deal. ${ }^{, 57}$ In December 1903, Latta fully demonstrated his lack of benevolence.

Among Dilworth's teeming thousands dwelt about fifty streetcar workers, employed by Latta's Charlotte Street Railway Company. Dan Morrill indicates these conductors operated streetcars six days per week, with twelve hour shifts. Depending on seniority, they could earn from 8 to 12 cents hourly, translating to 64 cents to $\$ 1.44$ daily wages. This translates to at least 33 percent better wages than most textile workers, but still very low in comparison with most urban streetcar workers across the nation. ${ }^{58}$

${ }^{56}$ Julia M. Alexander, Charlotte in Picture and Prose (Charlotte, North Carolina), 1906, 60; Morrill, Dilworth Neighborhood Guide; Twenty-First Reports, 328-9; Charlotte Observer, 11 November 1909, 6; Charlotte Observer, 27 June 1982.

${ }_{58}^{57}$ Morrill, Dilworth Neighborhood Guide; Alexander, 60.

${ }^{58}$ Morrill, Dilworth Neighborhood Guide. 
Latta's streetcar men received no vacation days, except for Christmas, when prizes were given to productive workers at a banquet held in the Central Hotel. But Latta's worst trait is evidenced by his parsimonious 1903 decision to cut off streetcar heaters to reduce winter operation costs. On December 2, 1903, forty-eight of Latta's motormen and conductors resolved to strike in protest. Initially, most of Charlotte's estimated 20,000 inhabitants sided with these beleaguered workers. ${ }^{59}$

Despite the national trend toward Progressivism, there existed few legal options for the workingmen to pursue in Charlotte. While labor unions certainly existed within city limits, North Carolina businessmen were under no serious pressure to negotiate with them. Even avowed Southern Progressives sometimes placed great confidence in their region's “enlightened industrialists." Boosters were similarly unreceptive toward labor reform, because such measures usually entailed recognition of labor unions. As late as 1913, the Charlotte Chamber of Commerce openly boasted of their city's low presence of trade unionism, which they described as a "disturbing element." But Charlotte's 1903 streetcar strike lacked any real union leadership. It seems that Southern industrialists were more than capable of creating disturbances. Historian Dan Morrill distinguishes Latta's conduct as "at worst self-serving, and at best only paternalistic." Moreover, he describes Latta's subsequent actions as "characteristic" of most New South capitalists. ${ }^{60}$ From New York City, Edward Latta directed his eldest son, Nisbet, to discharge his striking workers and replace them immediately. Upon his return to Charlotte on December 3, the elder Latta discovered quite a number of local citizens sporting protest

${ }^{59}$ Charlotte News, 2 December 1903, 1; Charlotte Daily Observer, 3 December 1903, 1; Morrill, Dilworth Neighborhood Guide.

${ }^{60}$ Carraway, 12; Link, xii; Morrill, Dilworth Neighborhood Guide. 
buttons, which read "I Walk." On that same evening, Charlotte's labor leaders met in the Typographical Hall to rally for the unorganized streetcar workers. Even the conservative Charlotte Daily Observer (the forerunner of today's Charlotte Observer) gave its conditional support to these striking workers, whose actions were restrained, at least initially. For once, it seemed that Charlotte workers might actually trump their employer and gain major concessions through public sympathy. ${ }^{61}$

But the Charlotte Street Railway men had not counted upon their employer's intractability and essential meanness. Latta's men agreed to return to their former jobs if their complaints were resolved. The workers' arbitration efforts were supported by F.C. Abbott, a respected city realtor who knew Latta professionally. On December 8, one week after the strike, Edward D. Latta agreed to restore heat to his company's electric streetcars. However, he refused to reinstate those forty-eight employees "who, without provocation... elected to abandon their position with no other expectation than that the company and the public would be without service." ${ }^{.62}$

Immediately, the public condemned Latta's summary dismissal of his streetcar men. Charlotte News editorials questioned Charlotte Consolidated Construction's integrity, even suggesting the city aldermen should review all of Latta's exclusive utility franchises. Moreover, the newspaper argued that perhaps municipal ownership would be preferable to renewing the "Four C's" contract for another ten years. The Charlotte News predicted a costly victory for Latta and Charlotte Consolidated Construction. ${ }^{63}$ While it might be too much to argue Latta's mishandling of the strike directly wrought the

${ }^{61}$ Charlotte News, 3 December 1903, 1; Charlotte Daily Observer, 4 December 1903, 1; 6 December 1903, 1.

${ }_{62}^{62}$ Charlotte News, 5 December 1903, 1; 8 December 1903, 1.

${ }^{63}$ Charlotte News, 8 December 1903, 1, 4. 
downfall of his own company, public opinion gradually eroded the image of Charlotte's once-invulnerable entrepreneur.

Unfortunately, mounting frustration among some Dilworth inhabitants spilled over, on the chilly evening of December 10. Patience has its way of evaporating when hunger and betrayal hang thick in the air. And so, two days after Latta announced his purge, hundreds of demonstrators converged on South Boulevard to protest hiring of scabs. No strikers were conclusively identified among the crowds. Reports indicated that the mob hurled stones through trolley windows, striking at least one conductor, who suffered an ankle injury. Witnesses also alleged the mob fired pistols in the air while streetcars rattled past. Charlotte police dispersed the crowd before serious violence erupted, but irreparable damage to the workers' cause had been inflicted. The Charlotte News sponsored a benefit show on December 21, featuring regional humorist Gilbert Warren. Yet, Edward Latta still emerged victorious, at least for the short term. None of his former crewmen were re-hired, and they gradually sought other employment. ${ }^{64}$ No evidence directly links public opprobrium to Consolidated Construction's downfall, but nonetheless, "profound changes" affected the company's fortunes over the following decade. In 1904, Charlotte's Board of Aldermen passed over the "Four C's" in favor of Duke's Catawba Power Company, which offered lower annual rates for city streetlights. Whereas Edward Latta billed the city $\$ 90.00$ for each pole, the Dukes drastically undercut their rival by charging $\$ 54.00$. That same year, Charlotte citizens also complained about the quality and price of the "Four C's" domestic gas services. That February, gas manager Nisbet Latta publicly defended his father's business

${ }^{64}$ Charlotte News, 11 December 1903, 1; 16 December 1903, 1; Charlotte Observer, 11 December 1903, 1; Morrill, Dilworth Neighborhood Guide 
practices, labeling their critics "socialists." Such outbursts only worsened the local reputation of Charlotte Consolidated Construction Company. ${ }^{65}$

By 1910, the Charlotte Board of Aldermen had turned completely against Latta, entertaining numerous bids from rivals, including Southern Power. After years of wrangling, Latta grudgingly sold his gas subsidiary - and trolley lines -- to Duke's growing empire that October. ${ }^{66}$ Despite Southern Power's gradual takeover in Charlotte, Edward D. Latta continued to shape Dilworth until his death in $1925 .{ }^{67}$

Duke still entertained plans to build electrified interurban streetcar lines across the region. Duke's own Piedmont Traction subsidiary had been growing alongside its parent, Southern Power, absorbing utility services across the Piedmont. In 1909, Southern Power purchased Anderson Traction Company, with Greenville Traction Company selling to Duke in 1910. Just before Piedmont Traction reorganized into Southern Public Utilities, Duke finalized a transaction for Spartanburg's entire power system in late 1912. This made Duke a partial owner of South Carolina Light, Power, and Railway. However, complications emerged when Southern Power actually came to rival its own subsidiary, South Carolina Power, Light and Railway (SCLP\&R), for services to Spartanburg. ${ }^{68}$

\footnotetext{
${ }^{65}$ Morrill, Dilworth Neighborhood Guide.

${ }^{66}$ Morrill, Dilworth Neighborhood Guide.

${ }^{67}$ Dilworth underwent two further stages of development in 1912 and 1920, following the "City Beautiful" trend. In 1911, Latta enlisted the Olmstead brothers to landscape and organize the newly annexed Dilworth, now part of Charlotte's Eighth Ward. Charlotte's once-powerful developer also established the 90-acre Latta Park, accessible via trolley. While Latta Park no longer attracts professional baseball teams or Buffalo Bill's Wild West Show, it still serves as one of Charlotte's major recreation centers. (http://landmarkscommission.org/S\&RR/HelmsBell.html Accessed 17 February 2009).

${ }^{68}$ After World War I, a third utility company, the Green River Power Corporation, emerged to challenge Duke's monopoly, but faced long and costly litigation. (Vernon Foster, Spartanburg: Facts, Reminiscences, and Folklore (Spartanburg: Spartanburg County Foundation, 1998), 389; Fetters, 69-95).
} 
With Charlotte's public utility portfolio under Duke's control by 1910, Southern Power's power base resided in the center of the Carolina Piedmont. Yet profits were still a serious concern. Already by 1910, automobiles had become a permanent fixture among Piedmont towns. The original 15-mile streetcar tracks built by Charlotte Consolidated Construction Company had been operating at only a modest profit margin, according to fragmentary records. North Carolina's Department of Labor published sporadic data on the state's street railways. The Department's 1907 report shows the Charlotte lines serving nearly 2.75 million passengers, about 183,000 per track mile. Despite being the second-largest trolley system in North Carolina, the Charlotte lines earned a mere $\$ 40,535$ when compared to transportation services such as Asheville Electric Company (14 miles operating at $\$ 97,738$ ) or Wilmington’s Consolidated Railways Light \& Power, whose 19 track miles brought $\$ 75,956 .{ }^{69}$

Moreover, Piedmont Traction's new assets required modernization and expansion. In 1911 and 1912, Southern Power devoted resources to these tasks. Anderson City Lines eventually linked up with Duke's Greenville, Spartanburg, and Anderson (GS\&A) Railroad. Eventually, Greenville, Spartanburg, and Anderson became closely tied in the South Carolina Upcountry, although it would be too much to attribute this entirely to James Duke. Greenville Traction Company (later Greenville City Lines) underwent major extensions to nearby textile mills -- including Duke's private interest at Westervelt Mill. Concurrent with these developments in South Carolina, nine trolley lines served Charlotte's streetcar suburbs, expanding to 20 track miles and 38 cars by $1916 .{ }^{70}$

\footnotetext{
${ }^{69}$ Twenty-First Reports, 328-9.

${ }^{70}$ Fetters, 69-95; Harkey, 68.
} 
To streamline Southern Power's corporate organization, Duke's Piedmont Traction merged its assets into the Southern Public Utilities Corporation in March 1913. This major subsidiary now governed Southern Power's widespread domestic electricity and gas services, in addition to public transportation lines. ${ }^{71}$ Governing this branch of Southern Power required someone with keen political skills, as well as a hard-nosed competitive streak. Throughout Duke's Piedmont \& Northern campaign, one man in particular had demonstrated these attributes. Zebulon Vance Taylor (1868-1921) would supervise Southern Power's vast public utilities service industry until his death. Having been a successful businessman raised in the old school, Taylor likewise proved a master of paternalism. As a booster in the Piedmont, Taylor enjoyed business connections with the major towns orbiting Charlotte. ${ }^{72}$

Zebulon Vance Taylor's origins were comfortably middle-class, given the economic chaos of Reconstruction. His parents, Dr. C.W. and Mariah Taylor, were native Tarheels temporarily living in Sparta, Tennessee when Zebulon Vance - named for the flamboyant Confederate governor of North Carolina -- came into the world on September 4, 1868. By age eleven, Taylor's family had relocated to Forsyth County, North Carolina, where their names appear in the 1880 Census. ${ }^{73}$ After attending Oak Ridge Institute, Taylor began his career as a telegrapher and dispatcher for Southern Railway. He completed the equivalent of a baccalaureate in his spare time, before studying law in Greensboro, under Judge W.P. Bynum. During the 1890s, Taylor met his future wife, Irving Scales, whose brothers took on the promising young attorney as a

\footnotetext{
${ }^{71}$ Fetters, 75.

72 Southern Public Utilities Magazine, Vol. 6, Nos. 11-12, (April-May 1921), 3-11.

731880 U.S. Bureau of the Census, Forsythe County, Greensboro, North Carolina.
} 
junior partner. Taylor thereafter entered Greensboro politics, serving two single-year terms as the city's mayor. Taylor took office on October 15, 1898, filling a vacancy left when his predecessor, John J. Nelson, resigned for a court appointment. ${ }^{74}$

Zebulon Taylor left politics in 1902 to assume the presidency of Greensboro Electric Company. Taylor held this position until 1910, when he joined Southern Power, which had just acquired the utility services of nearby Winston-Salem. Duke soon made Taylor a director of Piedmont \& Northern Railroad, to reward his efforts as a booster during their campaign. Meanwhile, Taylor managed several utility outlets for Southern Power, including Winston-Salem and Charlotte, until these branches were merged with South Carolina assets to form Southern Public Utilities in 1913. Zebulon V. Taylor became the first president of Duke's new subsidiary arm in the Piedmont. ${ }^{75}$

Zebulon Taylor proved an able lieutenant, managing daily operations and acting as a lightning rod for controversy during the 1919 streetcar strike. As a ranking member of the Charlotte Chamber of Commerce, Zebulon Taylor knew the right connections to secure influence during the crisis. As a business attorney, Taylor also played a leading role in Duke's court battle against North Carolina regulators. In short, Zebulon Taylor's uncompromising conservatism made him a strong enforcer, serving as the iron hand behind Southern Power's friendly exterior. ${ }^{76}$

\footnotetext{
${ }^{74}$ U.S. Bureau of the Census, 1880, Forsythe County, North Carolina; 1892-93 Greensboro City Directory, from http://www.greensborohistory.org/archives/Highlights_Pages/City_Directory_Pages/1892 93, Internet, accessed 12 April 2009; Arnett, 420.

${ }_{76}$ Southern Public Utilities Magazine, Vol. 6, Nos. 11-12, (April-May 1921), 3-11.

76 Southern Public Utilities Magazine, Vol. 6, Nos. 11-12, (April-May 1921), 3-11; Dan L. Morrill, The New South Elite in Control, available from http://danandmary.com/historyofcharch10.html; Internet, accessed 15 April 2003. Accessed 20 April 2003; Durden, 160. Hanchett, 190.
} 
Company literature later dubbed Taylor the "Father of SPU," owing to his "spirit of service" as well as his "tact and diplomacy." While such traits Taylor possessed to some degree, he also showed another side to those who challenged his authority. Taylor was a tenacious defender of business interests and an opponent of regulation, treating all critics with the tenderness of a "fist in a velvet glove." His opponents included the liberal Democrat Josephus Daniels, owner of the Raleigh News \& Observer, who described Taylor's "almost violent" tirades against business regulation. Daniels staunchly favored the regulation of Southern Power, also commented on Taylor's trademark "vehemence," which spills out like acid during the 1919 Charlotte strike. ${ }^{77}$

Because Taylor achieved his success in a milieu that scorned trade unions, he scorned organized labor as anathema. His formative years witnessed the Great Railroad Strike of 1877, the Haymarket Riot, and other great labor-capital disputes. Growing up in an environment so mistrustful of organized labor, it should come as little surprise he would oppose their representatives throughout his political and business career. But his opposition often took on personal dimensions, even to the point of abusive language.

Despite this character flaw, Zebulon Taylor became something of a regional hero. One Greensboro editorial, reprinted by Southern Public Utilities upon Taylor's death, acknowledged the company president's faith in the "resources of the South," including its people. Greensboro's eulogist described Taylor as a self-made man who never settled for mediocrity, finishing with an appeal to young men to follow the SPU executive's example in the "business of living." His fame extended as far afield as Chester, South

${ }^{77}$ Southern Public Utilities Magazine, (Vol. 6, Nos. 11-12), April-May 1921, 3-11; Dan L. Morrill, The New South Elite in Control. Available from http://danandmary.com/historyofcharch10.htm; accessed 22 April 2003; Durden, 160-66. 
Carolina, whose newspaper editors likewise spoke of Taylor's "fervor and enthusiasm," comparable to railroad builder James J. Hill. Such lavish tribute confirms Taylor's significance as a regional booster and developer of Southern Power's industry. ${ }^{78}$

One can also see parallels to Henry Clay Frick's erstwhile partnership with Andrew Carnegie in the steel industry. Unlike Frick and Carnegie's later falling out, Taylor's relationship with Duke never ended in acrimony - indeed, Taylor's loyalty to Duke lasted until the SPU president died, while on board his partner's personal railway car in 1921. However, labor history aficionados may see a comparison between Taylor's union-busting at Southern Public Utilities in 1919 and Henry Clay Frick's strong-arm tactics against organized steelworkers at Homestead, Pennsylvania. While lieutenants handled the strikebreaking with ruthless efficiency, James B. Duke, much like Andrew Carnegie, preserved his public image as a philanthropist and enlightened industrialist. Throughout the war decade, Zebulon Taylor became the most visible agent of Southern Power's relentless dynamo, with thousands of workers answerable to him. ${ }^{79}$

${ }^{78}$ Southern Public Utilities Magazine, (Vol. 6, Nos. 11-12), April-May 1921, 3-11.

${ }^{79}$ Further information on Carnegie and Frick may be obtained from Les Standiford, Meet You in Hell (New York City: Three Rivers Press, 2005), 144-95. 
Chapter 3: Labor Forward in the Piedmont Carolinas

This chapter analyzes the emerging labor movement in the Piedmont Carolina prior to World War I. Some Southern Progressives endorsed local unions, but many showed mistrust toward the American Federation of Labor and its affiliates, including the Amalgamated Association of Street and Electric Railway Employees. However, efforts to organize streetcar workers in the Piedmont often intersected with similar drives in regional textile mill villages, so both campaigns will be examined. Mill operators and their powerful allies in city and state government came to view outside labor organizations as a challenge to their authority. Moreover, national labor movements clashed with local businessmen over the treatment and representation of their streetcar workers. Since many of these public transportation workers operated in mill towns, employers tended to treat their streetcar crewmen in the same manner as textile mill employees. This seems especially true of Southern Public Utilities during its early phase, where Charlotte's trolley-men were among the lowest paid in the region.

According to Philip S. Foner, American streetcar workers uniformly received "deplorably low" wages, often working long shifts under the most unsafe conditions, including exposure and electrocution. Since its creation in 1892, the AASERE had represented nearly half of America's streetcar workers, chiefly in the North. However, by 1916 , national membership had risen to 60,000 , including Southern chapters in Louisiana, Tennessee, and South Carolina - the citadel of Southern textile industry. ${ }^{1}$

\footnotetext{
${ }^{1}$ Philip S. Foner, History of the Labor in the United States: Volume VII: Labor and World War I, 1914-1918 (International Publishers, New York City, 1987), 202-203;
} 
Southern textile workers were first mobilized by Knights of Labor in 1886. This early wave of textile organization affected workers in Charlotte, North Carolina, who vainly sought a union. Unionization efforts resurfaced in the Upper South with the National Union of Textile Workers (NUTW) and its later incarnation, the United Textile Workers of America (UTWA). As Dewey Grantham points out, nearly all textile strikes before the First World War met with total defeat, largely due to AFL indifference toward the "episodic and ephemeral" nature of Southern labor protest. According to historian William B. Tindall, textile labor unions were practically moribund in the Carolina Piedmont by 1921. Sympathetic municipal courts allowed corporate lawyers to file injunctions against unions, while National Guardsmen and police forces broke strikes, sometimes aided by private investigators and professional strikebreakers. ${ }^{2}$

Long before this well-documented defeat of labor, union-busting partnerships existed between state authorities and businessmen. For example, the Augusta streetcar strike of 1912 resulted on September 23 only after the powerful Augusta-Aiken Railway \& Electric Corporation refused to negotiate with the national streetcar union over the formation of Division 577. Augusta-Aiken Railways, much like Southern Power in Charlotte, crossed state lines between Georgia and South Carolina, owning all streetcar and inter-urban railways between these two major towns. At the insistence of Augusta's mayor, Georgia Governor Joseph E. Brown gladly sent the state militia into a town

Philip S. Foner, History of the Labor in the United States: Volume VIII: Postwar Struggles, 1918-1920 (International Publishers, New York City, 1988), 102-116.

${ }^{2}$ Dewey Grantham, Southern Progressivism: The Reconciliation of Progress and Tradition (University of Tennessee Press, Knoxville, 1983), 291-92; George B. Tindall, The Emergence of the New South: 1913-1945 (Baton Rouge: Louisiana State University Press and the University of Texas, 1967), 339-40. 
already plagued with strikebreakers, provoking minor incidents of violence that Brown thereafter blamed on the AASERE. ${ }^{3}$

Another reason for Southern resistance toward the national labor movement lay with some local craft organizations, which suspected the motives of "big labor." Most Southern union members were skilled craftsmen more interested in protecting their jobs. Sometimes with tacit support from manufacturers and businessmen, these conservative unionists were not particularly interested in helping unskilled laborers rise above their low-paid stations. Hence, construction workers and longshoremen in the coastal ports of Savannah and Charleston were able to unionize effectively, but Upcountry textile workers were strongly discouraged from taking such a course. ${ }^{4}$

Meanwhile, textile mills burgeoned in the South, as more Northern businesses relocated to the Carolinas and Georgia for lower wages and weaker local unions, if any. Throughout the period between 1915 and 1925, George B. Tindall noted "subterranean turbulence" in the Piedmont mill villages, signs of developing class alienation. This "widening gulf" between textile workers and bosses reinforced impressions that cotton mill workers were becoming "a hereditary occupation group." While connected to mainstream America by railroads and newspapers, Piedmont mill towns were effectively isolated, with their own churches, schools, and company stores. As their work-force enlarged during the war years, mill workers became restive toward their employers. Tindall stresses this class consciousness came less from labor militancy, more from a

\footnotetext{
${ }^{3}$ Fetters, 65-66; Motorman and Conductor, Vol. 20, No. 11 (October 1912), 14.

${ }^{4}$ Grantham, 180-85, 290-91; Link, 174-75.
} 
sense of desperation and isolation. ${ }^{5}$ But when the mill towns did become energized, as in past cases in South Carolina, mill operators instinctively looked for troublemakers to blame for circumstances largely within their own control. Despite the AFL's relative conservatism, Southern industrialists freely associated them with IWW radicals.

While mill owners expected the state governments to support their campaigns against labor unions, North Carolina Governor Locke Craig and his Palmetto counterpart, Richard I. Manning, were both products of Southern Progressivism. Even though both governors owed their elections to conservative Democratic constituencies, they were also swept up in Wilson's progressive "New Freedom" platform. Long a foe of corporations, Governor Craig became known as the "Good Roads" governor of North Carolina, improving the state's Piedmont and Appalachian regions with modern highways. Under Craig's successor, Thomas Bickett, state legislators also fought to control utility rates in North Carolina. Meanwhile, Governor Manning commenced a short period of political reform, following his personal victory over demagogue Coleman T. Blease in 1914. In short order, Manning overhauled state taxes, outlawed labor by children under fourteen, and set up a Board of Arbitration for labor disputes. Manning also recognized state labor unions and broke the power of company stores. His successor, Robert A. Carpenter, furthered this progressive trend. ${ }^{6}$

${ }^{5}$ George B. Tindall, The Emergence of the New South 1913-1945 (Baton Rouge and London: Louisiana State University Press, 1967), 339-40.

${ }^{6}$ Robert M. Burts, Richard Irvine Manning and the Progressive Movement in South Carolina (Columbia: University of South Carolina Press, 1973); David Carlton, Mill and Town in South Carolina 1880-1920 (Baton Rouge and London: Louisiana State University Press, 1982), 258-59; Tindall, 20-22; Greenville Daily News, 11-18 July 1914; 26 July 1914; 4, 16, 18 August 1914, 2, 6 September 1914; Spartanburg Journal, 21 August 1914. 
At the same time, Governor Richard I. Manning retained something of a provincial outlook on organized labor. As a wealthy South Carolinian with conservative states-rights roots, Manning took a dim view toward "foreign" labor agitators, linking their brand of radicalism to his immediate predecessor. As governor, Coleman Livingstone Blease thrived on "petty bickering and turbulence.” But despite Blease's ruthless suppression of IWW strikers at Greenville's Monaghan Mill in July 1914, he also used local unions for his own patronage. Following Blease's ouster that November, his disgruntled followers, known as "Bleaseites," often encouraged mill walkouts in the Upcountry. Bleaseites played to white supremacy, alleging that textile businesses treated white "lint-heads" worse than black slaves. However, these agitators served more to undermine Manning's authority than to help exploited workers. ${ }^{7}$

Monaghan Mill's strike in July 1914 attracted some modest national attention, due to Joseph James Ettor's involvement. Best-known for leading the 1912 Lawrence textile strike, Ettor staged Socialist demonstrations in sympathy with the striking Greenville textile workers. One local Wobbly supporter even carried a red banner in a downtown parade. Many South Carolinians saw Ettor as the sort of "outside agitator" they feared most in organized labor. For nearly two months, Monaghan Mill ceased operation. However, the Industrial Workers of the World soon decamped from the South Carolina Upcountry, after their efforts proved fruitless. Monaghan Mill owner Lewis Parker

\footnotetext{
${ }^{7}$ Further examination of Governor Blease can be found in Bryant Simon, A Fabric of Defeat: The Politics of South Carolina Millhands, 1910-1948 (Chapel Hill: University of North Carolina Press, 1998), 17-23; Walter Edgar, South Carolina: a History (Columbia: University of South Carolina Press, 1998), 473-7; Carlton, 258-59; Tindall, 21-22.
} 
quickly settled with his own workers, but other mills in the region began sacking workers suspected of being Wobblies. ${ }^{8}$

Under Richard Manning’s governorship, the small Upcountry city of Anderson encountered further labor unrest in early 1916. Since the previous year, UTWA organizers had sought to unionize Brogon Mill. To punish their rebellious workers, Brogon Mill's owners sought to evict the striking workers from company housing, in violation of rental contracts. Despite his Progressive leanings, Governor Manning used the Palmetto National Guard to enforce the company's eviction notices. This action brought the strike to a halt, intimidating workers into silence. Carlton explains the governor's actions as those of a "scion of an old planter family," who later became a successful banker. This fits well with the previously established premise that Southern Progressives preferred to handle their own reforms at the state and local levels, resenting outside interference. However much Governor Manning personally disliked using state troops in such fashion, he also felt an obligation to uphold the social order as he perceived it. As a businessman himself, Manning placed the interests of South Carolina business foremost. ${ }^{9}$

Manning's exercise in conservative policy had its dividends; he sacrificed national labor unions to secure state-wide political support. Initially lukewarm toward Manning's progressive stance, the Upcountry mill owners backed the governor's reelection against Coleman Blease in November 1916. Even the reactionary "Pitchfork" Ben Tillman supported Manning, despite his progressive reputation, because he dealt a

\footnotetext{
${ }^{8}$ David Carlton, Mill and Town in South Carolina 1880-1920 (Baton Rouge and London: Louisiana State University Press, 1982), 258-59.

${ }^{9}$ Carlton, 258-59; Tindall, 21-22.
} 
sound blow to the "damned factory class." Moreover, some urban workers in Anderson and Spartanburg came to see outside unions as detrimental to their livelihood. Employers warned that union-dictated wages would result in massive unemployment. Most Upcountry textile workers aspired toward steady income, despite the widening divide between skilled and unskilled workers. ${ }^{10}$

While Carlton's work deals mainly with South Carolina, one sees numerous similarities to the North Carolina Piedmont. Charlotte and her satellites proved resistant toward outside reformers, who were systematically viewed as intruders. Like vigilant seraphim, Rotarians and other "organization men" zealously guarded admittance to the burgeoning New South middle class. Many residents decried a "new class of loafers" vaguely attributed to "foreign" influences. During the mid-1880s, factory workers, dependent upon their employers for home and livelihood, sided with textile mill owners against the local Knights of Labor. Some successful trade unions came to Charlotte in the 1890s, as farms failed and urbanization spread across the Piedmont. For example, the Brotherhood of Locomotive Engineers established Charlotte Division 84 in 1894.

Indeed, most of Charlotte's local unions before 1910 reflected a bias toward craft workers and skilled tradesmen. For unskilled workers, such as the new mill class, few advocates dared to plead their cases until well into the next century. ${ }^{11}$

According to Janette Greenwood, the strongly Methodist Charlotte region had its own paternalistic reform movement, the Charlotte Humane Society, sponsored by

\footnotetext{
${ }^{10}$ Carlton, 258-59; Tindall, 21-22; 339-40.

11 Thomas W. Hanchett, Sorting out the New South City (Chapel Hill \& London: University of North Carolina Press, 1998), 74-75; Edward Martin, "N.C. Labor Efforts Written in Blood," from Charlotte News, 5 September 1983, 1A-3A; Tindall, 339-40; Tullos, 146-49.
} 
ministers and lay members, who began advocating temperance and cleanliness among the benighted mill workers during the 1890s. One of these reformers, Frank Ramsey McNinch, later became Charlotte mayor in 1918, presiding over the city during its violent streetcar strike. These Protestant reformers, notably suspicious toward Catholics and Jews, also believed themselves the rightful guardians of impoverished mill families, resenting outside interference from labor agitators. Many skilled craftsmen from Charlotte and Gastonia were similarly divided between progressive self-interest and provincial attitudes toward unskilled laborers. ${ }^{12}$

Were streetcar workers skilled or unskilled workers? In 1915, Congressman Stephen G. Porter of Pennsylvania served as arbitrator during Pittsburgh's streetcar strike on behalf of Division 85. Dissenting from the majority opinion, ruling streetcar crewmen were no more important than other wage workers, Congressman Porter stated his views on the streetcar profession. By dint of their rigorous training and responsibility, streetcar men deserved concessions to ensure high levels of performance and morale. While Pittsburgh's three thousand streetcar workers might seem worlds apart from Charlotte or Columbia's mere hundreds, their overall professional development bears comparison. ${ }^{13}$

North and South Carolina streetcar men underwent six months of training, and were not considered the equivalent of journeymen until two years passed. According to Stephen Porter, prospective motormen and conductors underwent medical examinations to ascertain fitness and sobriety before entering a period of apprenticeship. All streetcar employees could be routinely tested for technical knowledge and rules comprehension by

\footnotetext{
12 Janette T. Greenwood, The Black and White Better Classes in Charlotte (University of North Carolina Press: Chapel Hill \& London, 1994), 128-29.

${ }^{13}$ Motorman and Conductor, February 1915, 4.
} 
inspectors. Pittsburgh streetcar workers memorized 167 regulations. Given the complex nature of electric streetcars, workers were expected to be mindful of machinery as well as passengers and pedestrians. Exposure to elements and disease were constant risk factors. Moreover, these professionals had to maintain neat uniforms, handle money, and meet unkindness with "forbearance and self-control." Congressman Porter concluded that, given these different criteria, electric street railway employees should be considered in the same light as a locomotive engineer. ${ }^{14}$

However, in Southern mill towns, especially in the Carolina Piedmont, streetcar companies relied more heavily on low-wage laborers. Since streetcars often ferried textile mill workers, this may have reinforced the perception that motormen and conductors were also part of the "factory class." As Southern Public Utilities belonged to a larger corporation with textile mill interests, this may also helped justify Zebulon Taylor's overriding policy of low wages for his streetcar men. After all, Southern Power had appropriated streetcar lines as an outgrowth of urban electrification. Without union representation, SPU workers earned from eight to twelve cents hourly, according to organizational reports sent to the AASERE in June $1913 .^{15}$

Such reports doubtless troubled William D. Mahon (1861-1949), International President of the Amalgamated Association of Street and Electric Railway Employees (AASERE) since its inception in 1892. Time Magazine described Mahon as an "old-time

${ }^{14}$ Thirty-Second Report of the Department of Labor and Printing of the State of North Carolina (Raleigh, North Carolina: Edwards \& Broughton Printing Company, 1921), 3539; Motorman and Conductor, February 1915, 4.

${ }^{15}$ Charlotte's low wage figures had not changed since 1903. These figures are especially shocking when compared to Northern cities, such as Akron, Ohio, where streetcar men earned 18 to 20 cents, or Chicago, where workers received up to 25 cents. (Motorman and Conductor, July 1913, 15). 
crony" of Samuel Gompers. Hailing from Detroit, Mahon's leadership is best described as conservative and traditional. Mahon's organization primarily served the interests of transit workers across the United States and Canada. In marked contrast with other AFL branches, the AASERE did not agitate for "closed shop" working conditions, although it stressed the benefits of union membership. While the AASERE's trade publication, Motorman and Conductor, focused more on Northern and Midwestern events, Southern chapters contributed sporadic progress reports. Asheville, North Carolina, and Columbia, South Carolina were both fairly regular correspondents from the Upper Carolina region, where the AASERE's relatively conservative approach toward labor activity found some acceptance among local governments. ${ }^{16}$

To illustrate this delicate relationship, the Labor Advocate of Columbia offers a rare first-hand glimpse of the conservative union ethos at work in a large Southern town. Writing shortly after the Armistice, Charles Henry describes his labor newspaper as "above all things American," decrying radicalism as a threat to "stable labor." The local editor also boasted that Columbia had "more organized workmen than ever in its history," thanks to worker patriotism during the war. Henry further clarified his position as a progressive conservative, espousing the late Theodore Roosevelt's "Square Deal." That this shibboleth had often been twisted by Southern employers did not escape the editor, as he further upbraided bosses who "sow discord" or "beat down wages." Henry considered corporate strikebreakers "no less an enemy... than is the bewhiskered [Red] now seeking to terrorize the country." 17

${ }^{16}$ Time, November 14, 1949, 20; Motorman and Conductor, February 1915, 4; Foner, History of the Labor Movement, Volume VIII, 102-116.

${ }^{17}$ Labor Advocate of Columbia, Vol. 1, No. 1 (1 August 1919), 4. 
Even before the First Red Scare, labor radicalism threatened the American

Federation of Labor's moderate reputation. Mahon once stated the international streetcar union's purpose was to peacefully assist its members in "meeting the troubles of life." Mahon's personal beliefs also espoused the Social Gospel, as evidenced by his devotionals in Motorman and Conductor. "If we give men full economic development... they will be better prepared for the future," he once wrote. Mahon also counted Northern business leaders among his colleagues in the National Civic Federation. Furthermore, Mahon remained an "adamant opponent" of radical labor groups, such as the Industrial Workers of the World, whose actions he blamed for sabotaging negotiations. However, the IWW also promoted equal memberships among women and minorities, in marked contrast with Samuel Gompers and William Mahon's policies. ${ }^{18}$

Despite William Mahon's policy of accommodation, his nationwide organization faced prevalent anti-labor sentiments. While hardly alone in its distrust of unionism, the "Solid South" proved difficult to crack. One implacable foe, Governor Joseph E. Brown of Georgia later described the AASERE as being "defiant of State and National laws and ruthless in committing murder." Citing incidents in Augusta (1912), Atlanta (1916), and Savannah (1918-19), Brown also decried "bloody violence against the public" across the nation. Governor Brown no doubt feared the Labor Forward movement, during which AFL memberships had risen dramatically to 1.75 million by 1916, with approximately 60,000 belonging to AASERE. ${ }^{19}$

\footnotetext{
${ }^{18}$ Motorman and Conductor, January 1899, 1-3, January 1911, 1; William Onasch, “The Streetcar Strikes of 1917-18," available from http://www.kclabor.org/streetcar_strikes_of_1917.htm.

${ }^{19}$ Joseph M. Brown to Z.V. Taylor [telegram] 26 August 1919, as printed in The Charlotte Observer, 27 August 1919, 3; Greenville Daily News, 28 August 1919, 4;
} 
Correspondingly, the AASERE had established a few significant footholds prior to World War I. In fact, Asheville, situated in western North Carolina, had organized under Division 128 in late 1899. Then as now, Asheville thrived on tourism and vacation homes during these early decades owing to its mountainous, scenic locale. Although by 1920, Asheville's general population only numbered 10,235; many times that number visited the city each year. Asheville Electric Company at its peak had 45 streetcars on 18 track miles to accommodate traffic. Asheville Electric Company's isolation may have discouraged Duke's interest in its acquisition. Moreover, AEC did very well before World War I. During 1911, services extended into West Asheville, where three new streetcar crews were recruited. ${ }^{20}$

Division 128 took pride in their town, "one of the most extensively advertised resort towns in the United States." However, relations with the Asheville Electric Company were not always harmonious. Division 128 informed the Amalgamated that "conservative observers" were present to remind them of their duty. On 3 May 1913, workers won a settlement for improved wages after a brief walkout in April. Division 128 's workers received wages beginning at 20 cents for the first year of employment more than twice the starting rate offered by Charlotte. ${ }^{21}$

William Millikan, A Union against Unions (St. Paul, Minnesota: Minnesota Historical Society Press, 2001); William Onasch, "The Streetcar Strikes of 1917-18," Kansas City Labor History Bus Tour, 1992, available from http://www.kclabor.org/streetcar_strikes_of 1917.htm, Internet, accessed 16 February 2007; Carole E. Scott and Richard D. Guynn, "The Atlanta Streetcar Strikes," Georgia Historical Quarterly 84 (Fall 2000), 434-59; Motorman and Conductor, November 1911, 36; Foner, History of the Labor Movement, Volume VIII, 102-116.

${ }^{20}$ Motorman and Conductor, April 1911, 31, June 1911, 36, November 1911, 36; Coleman and Humphreys.

${ }^{21}$ Motorman and Conductor, Vol. 19, No. 11 (October 1911), 28; Vol. 21, No. 6 (May 1913), 11; Vol. 21, No. 8 (July 1913), 15; Vol. 22, No. 6 (May 1914), 28. 
By 1915, Asheville's Division 128 had constructed its own union headquarters. Older employees had been replaced by a dozen new men who promptly joined the organization. Division 128's standing improved to the point of adopting benefits for widows and disabled members, in addition to international AASERE funds. Several members were able to begin families during this period, owing to substantial pay raises. In 1916, hourly wages increased commensurately by approximately two cents, with workers earning from 21 to 27 cents depending on seniority. This raise factored into Division 128's reported yearly wage increase of $\$ 7,600$, bringing Asheville Electric's streetcar workers just under the wage scales of most Northern cities. But these advancements did not come easily; Division 128's correspondent, known only as "Newt," indicated Asheville's tourists made the summer runs very challenging. ${ }^{22}$

Successful organizations in Asheville and Chattanooga provided a springboard for the union to break out of the Lower Appalachians, entering the Piedmont Carolinas for the first time in 1911-12. While the Amalgamated's campaign of 1919 stands as the most ambitious effort to organize public transportation, it was by no means the first operation. During the national upswing in labor membership before the Great War, AFL organizers led a comprehensive effort to unionize skilled workers in the Carolina Piedmont in the summer of 1911. On July first, AFL organizer W.A. Neal commissioned AASERE Division 566 in Charlotte, while later in August, AFL organizer Charles McDaniels and AASERE Special Organizer Ben Commons established Division 571 in Spartanburg.

${ }^{22}$ Motorman and Conductor, Vol. 19, No. 5 (April 1911), 31; Vol. 22, No. 6 (May 1914), 28; Vol. 23, No. 3 (February 1915), 30; Vol. 25, No. 2 (January 1917), 9. 
Motorman and Conductor covered both struggles, showing initial concern for their vulnerable compatriots in the Carolinas. ${ }^{23}$

Just prior to the formation of Southern Public Utilities, the Charlotte Electric Railway had 95 employees, 83 of whom comprised Division 566. Their union correspondent, "COR," described their rail system as "small in comparison" to larger cities, but "very thorough" in terms of regional service. With only one exception, Charlotte's streetcar runs were "agreeable." However, lamenting Charlotte Electric Railway's low pay scale, the writer indicated the company stood "at the bottom of the list" in comparison with other cities. Nonetheless, "COR" anticipated no serious obstacles to union recognition, despite some opposition from "lesser lights." According to this correspondent, Division 566's future rested on their new employers, who were "men of the highest type and... national reputation." 24

"COR"'s allusion could only mean James B. Duke and his partners, whose powerbase of hydro-electric dams, textile mills, and railways throve on low wages and unregulated commerce. Although no reports confirm this fact, Division 566's fate seems to have been eventual disbandment. Two years after unionization, Charlotte Electric Railway's wages had failed to improve under Southern Public Utilities' banner. Even their most senior employee could only hope to earn 11 cents hourly. After July 1911, "COR" sent no further communiqués to Motorman and Conductor, although someone from the newly formed Southern Public Utilities Company leaked the 1913 wage scale to

${ }^{23}$ Motorman and Conductor, Vol. 19, No. 9 (August 1911), 31; Vol. 19, No. 12 (November 1911), 10-11; Vol. 20, No. 3 (February 1912), 24.

${ }^{24}$ Motorman and Conductor, Vol. 19, No. 9 (August 1911), 31; Vol. 19, No. 12 (November 1911), 10-11; Vol. 20, No. 3 (February 1912), 24; Vol. 21, No. 8 (July 1913), 15. 
the union publication. This revealed that Charlotte workers initially fared no better under Duke and Taylor than they had under Edward Latta. 1916 efforts by AASERE executive Allen H. Burt to unionize Charlotte resulted in the immediate surrender of AASERE Division 695's charter. ${ }^{25}$ Hence, Zebulon Taylor's predetermined hostility toward labor unions was well-established years before the strike of 1919 .

Taylor's superintendent of street railways, Roswell Lawrence Wommack, also opposed the unionization of his subordinates. Wommack (1867-1940) came from Forsyth County - like Taylor -- and began his career with the electrification of the Yadkin River. After a brief stint in Savannah, Georgia, Wommack transferred to Charlotte Consolidated Construction Company, arriving shortly after Latta's Christmas purge of 1903. Wommack then went to work for Piedmont Traction in 1911, until that corporation merged to become Southern Public Utilities. Wommack then became superintendent of all Southern Public Utilities streetcar operations across the Piedmont, enjoying the sobriquet of "Charlotte's Street Railway King.,"

Wommack's assistant superintendent, Tull R. Drum, had more day-to-day contact with the city's streetcar men. Southern Public Utilities Magazine upheld T.R. Drum as a company success story, "climbing to a responsible position" through diligence and loyalty. Drum began his career with the Charlotte Street Railway System in 1905, after

\footnotetext{
${ }^{25}$ Motorman and Conductor, Vol. 19, No. 9 (August 1911), 31; No. 8 (July 1913), 15; Vol. 24, No. 10 (September 1916), 4-5.

${ }^{26}$ A.V. Harrill served as SPU vice-president, but seldom emerged in the public eye. Treasurer Edward .C. Marshall in time succeeded Taylor as company president. E.F. Taylor acted as general manager for the mammoth utility company, while its chief secretary, W.C. Parker, resided in Southern Power's head office in New York City. When Duke Power replaced their old streetcar lines in 1936, R.L. Wommack supervised the company's regional bus service until his death. (Southern Public Utilities Magazine, Vol. 4, No. 8 (September 1918), 13; Vol. 6, No. 8 (January 1921), 30-35; Vol. 6, Nos. 11 12 (April-May 1921), 46).
} 
serving three years in the U.S. Army. Within eight months of becoming a conductor, Drum received a promotion to inspector. Drum became assistant superintendent in 1910, ensuring that streetcar inspectors and platform men followed daily schedules and operated streetcars safely and courteously. Both Roswell and Drum were prosperous middle-management employees who owned their own homes, raised their families, and lived the American dream. But, like Taylor, they both opposed labor unions. ${ }^{27}$

Corporate literature also reinforced images of "self-made men" like Wommack and Drum. Southern Public Utilities Magazine (later renamed Duke Power Magazine) circulated among workers in the region served by the company. Part newsletter, part propaganda, this magazine influenced workers and perpetuated the company's self-image as a benevolent employer. Its first editor, Leake Carraway, began as a Charlotte booster. Carraway established SPU's publicity department in 1914, lasting through the war years only to resign in May 1919 for employment with another company. ${ }^{28}$

Carraway’s successor, John Paul Lucas, enjoyed professional ties to both local newspapers, the Charlotte News and Charlotte Observer. In 1905, Lucas served as assistant city editor for the conservative Observer, while he later edited the Evening Chronicle, a subsidiary of the Charlotte News. Lucas also dabbled with real estate until America plunged into Great War. Lucas then used his political influence in Raleigh to lead the wartime North Carolina Food Administration. Afterward, Lucas took over Southern Public's publicity just prior to the Charlotte strike. ${ }^{29}$

${ }^{27}$ Helms-Bell House, http://landmarkscommission.org/S\&RR/HelmsBell.html; Internet, accessed 17 February 2009; U.S. Bureau of the Census, 1920, Mecklenburg County, Charlotte, North Carolina.

${ }^{28}$ Southern Public Utilities Magazine, Vol. 5, No. 2, (July 15, 1919), 11-12.

${ }^{29}$ Southern Public Utilities Magazine, Vol. 5, No. 2, (July 15, 1919), 24-25. 
Throughout its circulation history, Southern Public Utilities Magazine targeted its gas, electrical, and streetcar workers with a mixture of professional development and doggerel poetry, much in the same fashion as Motorman and Conductor. Certain SPU workers may well have read the AASERE periodical, but they probably did so furtively. It is highly unlikely that Superintendent Wommack would not have approved such literature. Southern Public Utilities Magazine unabashedly competed against the union publication, reaching at least one railway employee in Cincinnati, Ohio. Imploring for a subscription, Harry Howard complained to Leake Carraway that his company did not publish its own magazine. Among the professional journals Howard listed as his favorite reading materials Motorman and Conductor was notably missing. ${ }^{30}$

Southern Public Utilities streetcar employees were cultivated from the immediate Carolina Piedmont region. Responsibilities of motormen and conductors require some description. Motormen typically handled the mechanical aspects of the streetcar, while keeping an eye on passengers. Conductors managed driving, braking, and fare collection. SPU streetcar runs sometimes exceeded ten hours, although North Carolina recommended the eight-hour workday. Literacy rates tended to be very high among streetcar workers, who needed to read schedules and so forth. Locomotive and streetcar conductors were listed as one hundred percent literate, for example. Streetcar conductors in North Carolina required five full years to establish seniority, and were required to be at least twenty-one. Motormen were somewhat lower on the rung than conductors, but they sometimes worked their way to conductor positions. ${ }^{31}$

\footnotetext{
${ }^{30}$ Southern Public Utilities Magazine, Vol. 4, No. 2, (March 15, 1918), 11;

${ }^{31}$ Thirtieth Reports of the Department of Labor and Printing of the State of North Carolina, 1916 (Raleigh: Edwards \& Broughton Printers, 1917), 31; U.S. Bureau of the
} 
Statistical analysis from Charlotte's Eighth Ward, also known as Dilworth, suggests a fairly typical variety of lifestyles for streetcar workers. Out of 36 Southern Public streetcar men inhabiting this contentious suburb, less than one-third (ten) were homeowners. Fifteen other streetcar men also rented their homes, rubbing elbows with mill workers, shopkeepers, and tradesmen. Eleven men either lodged with family or boarded with other streetcar workers. Such figures are slightly lower than those given by the 1920 U.S. Census report, indicating 37.7 percent of Southerners owned their homes, while 62 percent rented.

Two notable streetcar families interacted at every level in the Dilworth suburbs. Assistant Superintendent T. R. Drum, at age 44, owned a house in one of the better sections of Dilworth. Adolphus McFarland, working at age 61 as a car inspector, also owned a home in Eighth Ward. One son, conductor William A. McFarland, rented a home with his newlywed wife. Another son, Edward McFarland, shared a rented house with his fellow conductor, R. Olin Drum, presumably a relative of the Assistant Superintendent. $^{32}$

What more can we know about the ordinary motormen and conductors who worked for Southern Public Utilities? Their world is but a shadow of memory, photographs buried in archives. Most newspaper perceptions of the Carolina Piedmont streetcar men come from the company perspective. Zebulon V. Taylor could appear fatherly, not to say paternalistic. In 1919, Taylor often portrayed his "boys" as misled

Census Reports, 1920, Mortgages on Homes, 14-15; U.S. Bureau of the Census Reports, 1920, Mecklenburg County, Charlotte, North Carolina.

${ }^{32}$ At age 28, William A. McFarland served as the local streetcar union president throughout the Charlotte Strike. Edward McFarland listed his age as 29, while Olin Drum was 21 years old. (U.S. Bureau of the Census Reports, 1920, Mecklenburg County, Charlotte, North Carolina). 
children whose prodigality had brought them under "outside influences." They were "men" when they followed orders. Taylor's attitudes lent his workingmen little credit as to their intelligence or freedom of action. Loy Cloninger, one of the chief union spokesmen during the 1919 strike, later admitted that his fellow workers did not like Taylor overmuch, but were unable to express their sentiments openly. On the other hand, Taylor rewarded loyalty among streetcar workers who resisted the lure of unionism. ${ }^{33}$

Jesse B. Ashe (born 1887) began his career working on the Southern Electric Railway, eventually rising from lowly conductor to Southern Public Utilities streetcar inspector in the 1920s. Ashe had more positive feelings toward Zebulon Taylor, insisting he got along personally with his company president, and his co-workers "used to think a lot of him." Ashe nevertheless took part in the post-war Charlotte strike, accompanying Loy Cloninger to Chamber of Commerce negotiations with President Taylor.

Unfortunately, his interview with Allen Tullos only skimmed over the topic of the strike, focusing instead on the recreational activities and workaday details of his career. ${ }^{34}$

While Ashe's account is descriptive, one is also left with the impression his employers did not encourage him to remember the events of August 1919.

Jesse B. Ashe grew up working on a cotton farm in York County, South Carolina. In 1912, he left for the city of Charlotte in the company of his brother. They both went to work for Southern Electric Railway before its consolidation under the Southern Public

${ }^{33}$ Loy C. Cloninger, interview by Allen Tullos, 18 June 1980, transcript, University of North Carolina at Chapel Hill, Southern Historical Collection, Louis Round Wilson Library, 8.

${ }^{34}$ Jesse B. Ashe, interview by Allen Tullos, 13 June 1980, recording, University of North Carolina at Chapel Hill, Southern Historical Collection, Louis Round Wilson Library; Final Report of Commission, 23 August 1919, Department of Labor, Division of Conciliation, National Archives and Records Administration, Box 111. 
Utilities Company. Unlike his brother, who quit after six months, Jesse Ashe decided to make a career in public transportation. He retired from Duke Power in 1955, having made the transition from streetcars to motorbuses. As he recalled in 1980, "We weren't making much, about 14 cents an hour... seven days a week, nine hours a day, and no vacations." After five years as a motorman, Ashe became a conductor in 1917, but the pay increase only amounted to 21 cents hourly. This wage figure quoted by Ashe, amounting $\$ 1.89$ for a nine-hour shift, is well below the daily average of $\$ 4.50$ given by the 1916 North Carolina Department of Labor. ${ }^{35}$

According to Jesse Ashe, being a streetcar conductor had its unglamorous side. Manipulating the streetcar's nine points of speed proved "tough work," requiring two different gloves for handbrakes and other controls. Ashe's job forced him to "sit out in the cold, with the doors always open." Evidently, the heating for Charlotte streetcars did not improve greatly after the 1903 strike - which had occurred primarily due to that same issue. During his bachelor years, Ashe lived in a South Boulevard boarding house, directly across from the Dilworth car-barn, sharing a room with four other streetcar employees. Ashe's room and board amounted to $\$ 3.00$ weekly, later increased to $\$ 4.00$ after the war years. Ashe ruefully admitted his situation did not leave him with much money to save. Such dearth of income suggests Ashe likely had a strong financial motivation to join the Charlotte streetcar union in $1919 .{ }^{36}$

Judy M. Fourier, Ashe's sister-in-law, also revealed that Jesse's mother had dissuaded him from accepting a baseball scholarship during his youth. Whether Ashe's

${ }^{35}$ Ashe interview; Thirtieth Reports of the Department of Labor and Printing of the State of North Carolina, 1916 (Raleigh: Edwards \& Broughton Printers, 1917), 30.

${ }^{36}$ Ashe interview; United States Census Reports, 1920, Mecklenburg County, Charlotte, North Carolina. 
mother held religious prejudices toward professional sports is unclear. Perhaps, Ashe felt immediate employment might help his family's cotton farm, which may not have been faring well. Beyond question, Ashe's decision haunted him throughout his life. Early in his career, conductor Jesse Ashe made quite a reputation for himself as a promising pinch-hitter for the Southern Power baseball team. In 1980, Ashe recalled that company vice-president William States Lee played alongside his men, rewarding good hits with a dollar bonus. Home runs brought three dollars to the skilled athlete's paycheck. While some of Ashe's acquaintances went to the major leagues during the Twenties, marriage and fatherhood forced the conductor to give up baseball entirely. ${ }^{37}$

Loy Connelly Cloninger (1893-1985) came from Lincoln County, North Carolina, where his father built houses. Best known as "L.C." to his compatriots, Cloninger did not begin working for Southern Public Utilities until 1917. By then, wartime drafts brought vacancies to the region's major employers. Being married with one child, he received exemption from the draft. In search of stability, L.C. turned down a short-term construction job, paying daily laborers $\$ 9.00$ to build a gunpowder plant in City Point, Virginia. Instead, Loy Cloninger began working for SPU as a night-shift streetcar mechanic at $\$ 1.75$ per day. He moved temporarily into a rooming house known as the Flatiron Building, until he could afford to bring his family. ${ }^{38}$

L.C. received a personal recommendation from his older brother, J.L. Cloninger -already a popular streetcar conductor nicknamed "Klondike" for his wealth of anecdotes and jokes. Relatives often helped one another find gainful employment. One brother-inlaw, W.V. Osborne, later came to the Charlotte SPU maintenance section, becoming a

\footnotetext{
${ }^{37}$ Ashe interview.

${ }^{38}$ Cloninger interview, 1-2.
} 
master mechanic. Within two years, Loy Cloninger himself became night foreman, and a confirmed unionist. During his 1979 interview, Cloninger showed a badge from the Brotherhood of Railroad Trainmen, indicating twenty years of membership. This would suggest a closer relationship between street railway workers and locomotive trainmen after the Charlotte Strike. Since its establishment in Charlotte predated the streetcar union by two decades, the railroad union may have taken up the slack for street railway workers. ${ }^{39}$

Cloninger's work involved winding electrical armatures in streetcar motors, as well as trolley controllers. Sometimes, when Charlotte streetcars went off track, L.C.'s crew put them back on course. This task actually exposed the workers to extreme hazards. One crewman named King received a lethal jolt of 550 volts while repairing a fallen trolley near the Lakewood district. On this occasion, King unwisely used bare hands to pick up the non-insulated pole feeding power to the streetcar motor. Cloninger recalled he must have "been stuck hundreds of time on top" of the streetcar, with the live wire right next to him. Remorsefully, he repeated an old maxim for streetcar workers on the trolley lines: "Grab a pole and get it all." ${ }^{40}$

Cloninger's account is significant, not to say unique, for its references to interracial unionism, albeit within strict limitations. When the Charlotte organization drive began in 1919, Cloninger recalled union meetings were open to black transportation workers, but no evidence exists to confirm that blacks took leadership roles. Loy

\footnotetext{
${ }^{39}$ Thirtieth Reports of the Department of Labor and Printing of the State of North Carolina, 1916. Raleigh: Edwards \& Broughton Printers, 1917, 32; Southern Public Utilities Magazine, (Vol. 1, No. 9), October 10, 1915, 32; Cloninger interview, 1-2.

${ }^{40}$ Charlotte's 1920 Census indicates three motormen named King, two of them living in Ninth Ward, and the third living in Second Ward. (Cloninger interview, 9-10; U.S. Bureau of the Census, 1920, Mecklenburg County, Charlotte, North Carolina).
} 
Cloninger also indicated little friction between blacks and whites at the local union meetings. But given the context of Jim Crow, relationships were sometimes tinged by condescension and paternalism. When interviewed in 1979, Loy Cloninger shamelessly referred to "an old nigger," who chided a fellow streetcar mechanic - a white man from Georgia -- for refusing to join the local union after complaining about low wages. ${ }^{41}$

Southern Public Utilities streetcar employees, black and white, frequently interacted in the shops and car-barns, where returning vehicles were cleaned and repaired after each nightly run. Unfortunately, when viewed through the lens of white authority, African-American streetcar workers in the Piedmont largely remain a mystery. According to Philip S. Foner's labor history, black employees in most streetcar companies were relegated to servile positions, such as porters and sweepers. Southern Public Utilities seems no different in this sense. No 1920 census data confirms the employment of black motormen or conductors. However, at least ten African-Americans held maintenance jobs in Charlotte. Six black men were general laborers in the car barns, while other individuals fulfilled specific duties, such as track maintenance or car cleaning. Only a single black streetcar employee, Frank Moss, at age forty-two, held a significant skilled position as car-barn electrician, inspecting the streetcar wiring systems. Moss and his family of five rented their home in Third Ward, a predominately black sector of Charlotte. ${ }^{42}$

Charlotte also boasted two segregated black streetcar suburbs, Biddleville (1903) and Washington Heights (1912). Often referred to as "Black Dilworth," Biddleville had

\footnotetext{
${ }^{41}$ Cloninger interview, 2-3.

${ }^{42}$ Cloninger interview, 2-3; U.S. Bureau of the Census, 1920, Mecklenburg County, North Carolina.
} 
its own college, and provided employees for two cotton mills. One might assume that, under the vagaries of Jim Crow, streetcars going through Biddleville and Washington Heights might have been operated by African-Americans. However, Southern Public Utilities were proprietary toward "white" jobs, outweighing any perceived stigma of running streetcars through a black neighborhood. Moreover, black citizens of Charlotte rode toward the back of segregated streetcars, partitioned with a screen. AfricanAmerican conductors would certainly have posed a challenge to this system. ${ }^{43}$

Southern Public's Jim Crow policy toward its streetcar lines seems representative of the era's contradictory racial policies. In Making Whiteness, Grace E. Hale acknowledges a permeable color line aboard Southern streetcars, which she terms as "disorder" amid Jim Crow's "racial order." Grace Hale echoes Progressive Era writer Ray Stannard Baker's description of streetcars as relatively free "points of human contact." However, she also paraphrases Robin Kelley's argument that Southern streetcars continued as "arenas of racial struggle" until motorized buses took their place in the Civil Rights era. ${ }^{44}$

Most black Southern Public Utilities employees worked in the most dangerous occupations, chiefly in gasworks installation. John Ellis, one black construction worker,

43 "Thomas Edison's Firm Installed Trolley to Dilworth," Charlotte Observer, 27 June 1982, Special Advertising Section, 1-2; Daisy Stroud, interview by Melinda Desmarais. 20 June 2001, transcript, Special Collections, J. Murrey Atkins Library, University of North Carolina at Charlotte; Josephine Clement, interview by Kathleen Nasstrom, 13 July 1989 and 3 August 1989, transcript, Special Collections, J. Murrey Atkins Library, University of North Carolina at Charlotte.

${ }^{44}$ Grace E. Hale, Making Whiteness (New York: Pantheon Books, 1998), 133-5; August Meier and Elliott Rudwick, "The Boycott Movement against Jim Crow Streetcars in the South, 1900-1906," Journal of American History, 55, 4, (March 1969), 756-775; Jennifer Roback, "The Political Economy of Segregation: The Case of Segregated Streetcars," Journal of Economic History, 46, 4. (December 1986), 893-917. 
nearly perished from gas inhalation in 1919. Company publications described a white senior engineer, John V. Brookshire, using medical skills honed in wartime France to revive Ellis from his near-coma. Later, in 1920, the former ambulance driver rescued another black gasworks employee, Wylie Johnson. Both men appeared in what today would be considered a "photo opportunity." John Brookshire acted selflessly and above the call of duty in saving these two black workers. Yet, however much the company magazine emphasized human interest; these articles still possess an undertone of racial hierarchy. In both cases, black workers were portrayed almost like children who needed a white father to save them from danger. ${ }^{45}$

My research has not divulged any proof that Piedmont traction companies ever engaged black employees as replacement workers. Such tactics were not unknown in the Deep South; coal operators in Alabama employed black strikebreakers against the United Mine Workers in 1920, thwarting the UMW's interracial union efforts. But Piedmont newspapers of the era fail to make any mention of such decisions to hire black strikebreakers, a move that would conceivably strengthen local support for striking whites, despite anti-union prejudices. ${ }^{46}$

Spartanburg, located in the South Carolina Upcountry, proved even more hostile to unions than Charlotte. That city's connection to Southern Public Utilities' empire solidified in March 1913, with Duke's investment in Spartanburg's utility company, South Carolina Power, Light, and Railway (SCLP\&R). Franklin H. Knox remained the

\footnotetext{
45 Southern Public Utilities Magazine, Vol. 5, No. 5, October 1919, 23; Vol. 5, No. 9 , February 1920, 28.

${ }^{46}$ Brian Kelly, Race, Class, and Power in the Alabama Coalfields, 1908-21 (Urbana and Chicago: University of Illinois Press, 2001); Daniel Letwin, Alabama Coal Miners, 1878-1921: The Challenge to Interracial Unionism, (University of North Carolina Press: Chapel Hill, 1998); Grantham, 291.
} 
company's titular president, while his corporation enjoyed semi-autonomy. In early September 1913, Knox discharged several employees involved in the organization of Division 571. Knox also fired envoys from the local union when they pled for worker reinstatement. On September 23, Division 571 declared a strike that lasted four days. Spartanburg's city government brokered an "open shop" agreement with Knox, who promised to reinstate his workers at a pay scale of 14 to 18 cents, based on one to four years in service. However, a follow-up report in March 1912 indicated that SCLP\&R had rehired "very few" of Division 571's members. Despite AASERE organizer Ben Commons' best efforts, Spartanburg's first attempt to organize its transit workers met with failure. $^{47}$

Spartanburg's streetcar workers, like Charlotte's complement, tended to inhabit urban sectors, although a few motormen and conductors lived in outskirt farming communities. Most Spartanburg streetcar men were still renting homes by 1920, with some few homeowners, such as the streetcar "overseer" William H. Deming, a veteran employee at 57 years. Most of the Spartanburg streetcar men from First and Second Wards were married with several children per household. Adolescent children often worked at local textile mills. ${ }^{48}$

Like Southern Public, black laborers working for SCLP\&R usually held menial jobs, although George Evans served as streetcar repairman at the relatively young age of 26. Spartanburg's workers tended to live in segregated parts of town, but unlike the Queen City, Spartanburg tended to be less suspicious toward European immigrants.

\footnotetext{
${ }^{47}$ Motorman and Conductor, Vol. 19, No. 12, (November 1911), 10-11; Vol. 20, No. 3, (February 1912), 21; Vol. 20, No. 4 (March 1912), 9; Fetters, 69-95.

${ }^{48}$ U.S. Bureau of the Census, 1920, Spartanburg County, Spartanburg, South Carolina.
} 
Samuel C. Burris, a conductor in District 110, lived next door to a Russian Jewish shoemaker, whose eldest children worked in a department store. District 112, home to several streetcar workers, boasted a well-established Russian community. ${ }^{49}$

Despite setbacks in Charlotte and Spartanburg, the AASERE met with success in two major South Carolina towns, Charleston and Columbia. In the Palmetto state capital, 160 platform men from Columbia Railway, Gas \& Electric Company successfully unionized on May 24, 1912. Unlike Charlotte, Columbia's streetcar workers were not employed by Southern Public Utilities. Instead, the Columbia Street Railway also remained independent of Southern Power. Following a six-day strike, company president Edward W. Robertson signed a two-year "closed shop" contract on 25 October 1912. ${ }^{50}$

Division 590's president, Ambrose A. Gerald, led his chapter throughout its existence, commanding strong political clout at the local and state levels. Riding on South Carolina's wave of progressive reform, Gerald and another streetcar union member, William D. Hampton, were elected to state legislature in 1918. Included within the umbrella of Columbia's Federation of Trades (linked to the nationwide American Federation of Labor), streetcar conductors and motormen were represented equally as skilled workmen. Ambrose Gerald even served a term as the Federation President. Moreover, Division 590 repeatedly expressed its support for conservative leaders such as Governor Coleman L. Blease. In 1913, the Federation of Trades sponsored the Heat and Air Brake Bill, requiring South Carolina's streetcar services to install electric heaters and air brakes on all vehicles. With Governor Blease's vocal support, this legislation became

\footnotetext{
${ }^{49}$ U.S. Bureau of the Census, 1920, Spartanburg County, Spartanburg, South Carolina.

${ }^{50}$ Motorman and Conductor, Vol. 20, No. 10 (September 1912), 9; Vol. 20, No. 12 (November 1912), 32; Vol. 21, No. 1 (December 1912), 32; Fetters, 45-50.
} 
effective on 1 October 1914, ensuring the streetcar union's support for Blease in November. Division 590 even sent Mary White, teenaged daughter of one of its officers, bearing a bouquet of flowers to the Governor's Mansion. ${ }^{51}$

Columbia's streetcar workers were well-organized, but friction still persisted between Division 590 and its employers, despite their initial victory. After Cole Blease's defeat by Richard Manning in November 1914, Columbia's platform men relied less on state patronage, more on local arbitration efforts. In March of 1915, Division 590 received a settlement for higher wages, owing to a general perception that Columbia's street railway had fallen behind. Later in September, Columbia Light, Railway, and Gas Company allegedly began circulating "spotters" to keep tabs on their workers. Two men were sacked, prompting the union to strike for one week. Arbitration successfully ended the strike and reinstated the lost workers. ${ }^{52}$

"Spotters" were commonly used to check up on motormen and conductors in street railway systems, especially those belonging to unions. Wisconsin reported similar activities in March 1915, describing these spies as "reptiles" with the "inherent elements of a scoundrel." Workers from Peoria, Illinois, reported two pretty girls employed as "spotters" aboard a streetcar in October 1916. They were accused of intentionally provoking conductors and motormen into flirtation. Columbia's instances of company espionage focused upon whether the crewmen kept accurate headcounts of their passengers. Crewmen who made errors were unceremoniously sacked, sparking an

${ }^{51}$ Labor Advocate of Columbia, Vol. 1, No. 1 (1 August 1919), 1, 4; Motorman and Conductor, Vol. 21, No. 8 (July 1913), 23; Vol. 22, No. 7 (June 1914), 22; Vol. 22, No. 9 (August 1914), 24; Vol. 26, No. 12 (November 1918), 1.

${ }^{52}$ Motorman and Conductor, Vol. 23, No. 4 (March 1915), 22; Vol. 23, No. 11 (October 1915), 14; Vol. 23, No. 12 (November 1915), 23. 
outcry from Division 590. While only Governor Manning could overrule such a checking system, arbitrators were successful in convincing the company to desist in its practice. On this rare occasion, Division 590 sent for outside help to enforce the arbitration process. J.C. Colgan of the AASERE's General Executive Board oversaw the reinstatement of workers discharged in September 1915. Columbia's street railway men were also mollified by a modest pay raise in the spring of $1916 .{ }^{53}$

Columbia's streetcar workers were mainly South Carolina men, with a few from Georgia or North Carolina. Much like their counterparts in Charlotte and Spartanburg, the Columbia car men effectively barred their profession from African-Americans, although Columbia Light, Railway, and Gas Company did employ at least one black woman, Eva Smith, as a car-barn laborer. Nearly all workers from First Ward of Columbia either rented or lodged with someone. Charley Morgan, married with four stepchildren, provided lodgings to three other conductors and motormen in District 80 . Even Ambrose A. Gerald, a member of South Carolina's General Assembly and local union leader, still rented his own house in Fourth Ward, District $88 .{ }^{54}$

Despite these economic setbacks, Columbia's streetcar union had won both recognition and a closed shop contract. Resolving their differences with company president Edward Robertson, Division 590 of Columbia remained a vital mainspring of South Carolina labor throughout the next three years, serving the interests of public and company alike. Unlike cities such as Chattanooga, Tennessee, or Atlanta, Georgia, Columbia did not experience notable transportation strikes during the Great War. Until

${ }^{53}$ Motorman and Conductor, Vol. 23, No. 5 (April 1915), 15; Vol. 23, No. 11 (October 1915), 14; Vol. 24, No. 4 (March 1916), 9; Vol. 24, No. 4 (April 1916), 29; Vol. 24, No. 12 (November 1916), 29.

${ }^{54} 1920$ U.S. Bureau of the Census, Richland County, Columbia, South Carolina. 
Columbia Light, Railway, and Gas management changed for the worse after 1920, Columbia's streetcar union remained a working model of wartime union cooperation.

Hence, some elements of organized labor were still able to penetrate the industrial South before World War I, even in the Carolina Piedmont. While full unionization of the textile mills still seemed impossible, the existence of Columbia's Division 590 represented a new birth of unionism for semi-skilled workers. However, even the AASERE's superior organization had failed to tackle James Duke's powerful utility and industrial empire, now headquartered in Charlotte. After the United States entered World War I, streetcar labor unions reached their peak in power, even as traction companies fell under government control or went into receivership. However, Southern Power prospered in the war years, largely due to its connection with James Duke. Even though wartime influence enabled the Amalgamated to reach out once more toward the Piedmont, Duke still remained an implacable - if imperceptible -- foe of unionism. 
America's official involvement in World War I ignited hopes for organized labor across the United States. AFL leadership tended toward moderation and cooperation with business, using strikes only as a last resort. In late 1917, President Wilson approved the National War Labor Board (NWLB), chaired by ex-President William H. Taft. This body of arbitrators resolved many strike situations to facilitate wartime production and transportation. By supporting the war, the American Federation of Labor also hoped the Wilson Administration would lend its political support for labor organizers operating in states hostile to unionism. Meanwhile, federal crackdowns on labor radicals such as the IWW met with few objections from Samuel Gompers and William Mahon of AASERE. Yet, despite such cooperation from labor leaders, conservative newspapers across the U.S. portrayed unions as wartime malcontents and potential traitors. Southern newspapers led the way, often adding charges that unions incited racial tensions. ${ }^{1}$

During World War I, William Mahon delegated more authority to his chief lieutenant, William B. Fitzgerald. Fitzgerald, a one-time factory worker in Troy, New York, switched careers in 1896 to become a streetcar conductor. Fitzgerald's successful organization of Troy's streetcar union, Division 132, soon brought him to Mahon's notice. In 1903, Fitzgerald joined the Amalgamated Association's executive board. Rising through union ranks, Fitzgerald had become the First International Vice President

\footnotetext{
${ }^{1}$ Carole E. Scott and Richard D. Guynn, "The Atlanta Streetcar Strikes," Georgia Historical Quarterly 84 (Fall 2000), 434-59; Frank L. Grubbs Jr., The Struggle for Labor Loyalty (Durham, N.C.: Duke University Press, 1968), 35-55; McCartin, 68-70.
} 
in 1917. Throughout World War I, Fitzgerald personally oversaw all but the most difficult strikes and arbitrations. ${ }^{2}$

As Joseph McCartin denotes, a "chilling conformity" overtook the United States during World War I, as reactionary impulses silenced dissent among the ranks. The Espionage Act provided government officials with the tools to silence the IWW, while organizations like the American Protective League (and its local equivalents) suppressed other groups, such as the pacifist Non-Partisan League. While union-busting organizations like the Minneapolis Citizen's Alliance existed before the war, such groups gathered support and membership during the war, convincing many that labor unions were working hand-in-glove with Bolsheviks. ${ }^{3}$

Public transportation also underwent changes during World War I. While Southern traction companies never went so far as hiring female "conductorettes," as New York City did in 1918, they shared many common problems with Northern companies. One ongoing major problem lay with fluctuating wages and car fares. Transportation workers facing increased work hours during the war often received war bonuses from their employers. Some of these raises were the results of NWLB arbitration, citing the cost of living increases in 1918 and early 1919. In other cases, employers used the pay raise as a defensive tactic to ensure nearby strikes in such cities as Memphis and Spartanburg did not spread to their own work force. However, the traction companies also had to raise car-fares to make up for their overhead, which invariably aroused the

\footnotetext{
${ }^{2}$ Motorman and Conductor, June 1919, 27-28; December 1923, 1.

${ }^{3}$ Joseph A. McCartin, Labor's Great War (Chapel Hill: University of North Carolina Press, 1997), 108; Millikan, 87-123.
} 
riding public, who often felt they were footing the bill for labor unions. Sometimes, this public sentiment played into the hands of union-busters and employers, as we will see. ${ }^{4}$

In 1918, Southern Public Utilities workers were rewarded with two wartime bonuses in May and September to counter living expenses, raising effective wages to between 28 and 35 cents per hour. On 10 September, Zebulon Taylor addressed his platform men, stating his desire to grant even higher wages, but revenues under the fivecent car fare did not permit it. This carefully worded statement, with reminders of loyalty and duty, served to recruit worker support for higher car fares. If the company president's statement also served as a backdoor plea for the Piedmont region's towns to approve a fare hike, then it succeeded. On the first of October, as the war ground to a close, Charlotte and Winston-Salem raised fares to seven cents, followed by South Carolina towns such as Anderson, Greenville, and Spartanburg. Generally, the Piedmont citizenry accepted this hike with the usual wartime attitude of sacrifice. The Greenville News, for example, acknowledged that their SPU branch had been operating at a loss, and townsfolk preferred a modest increase in car fares in lieu of raising electricity rates. ${ }^{5}$

Columbia's Division 590 did somewhat better than the unorganized Southern Public streetcar workers during World War I. During Camp Jackson's existence, a fivemile extension connected soldiers to Columbia, adding an estimated 30,000 passengers to the system. In 1917, Ambrose Gerald lobbied to protect his chapter's jobs through a city

\footnotetext{
${ }^{4} 171$ New York women applied to become conductorettes within one day, with 91 being employed by late 1918 . While no proof indicated SPU ever considered hiring white women, Southern gender expectations did not preclude one editorial suggesting the employment of black women in hazardous jobs, such as gas line installation. (Southern Public Utilities Magazine, Vol. 4, No. 6, (July 1918), 8-10, 27, 44; Southern Public Utilities Magazine, Vol. 4, No. 8, (September 1918), 8-9, 13-16).

${ }^{5}$ Southern Public Utilities, Vol. 4, No. 8, 1-3; Vol. 4, No. 9-10, 24-25.
} 
ordinance blocking the use of one-man streetcars. Moreover, the city of Columbia passed a transportation law requiring streetcar crews to have fifteen days of training under motormen and conductors, each of these trainers being required to have six months or more track experience. ${ }^{6}$

From 1917 to 1919, Columbia Railway and AASERE Division 590 resolved their differences without resorting to strikes or lockouts. Nearly all Columbia employees, excluding part-time "extras," belonged to the union, which exercised restraint during the war years. In January 1917, Ambrose A. Gerald assumed leadership of the Columbia Federation of Trades, perhaps explaining his chapter's high level of discipline. Only weeks before America entered the war, the company granted a major wage increase. Regular employees received from 19 to 24 cents hourly, slightly below Asheville's rate. One year later, 1918 rates improved to 20 cents for new employees, working upward to 27 cents for senior crewmen. Columbia Railway also instituted a wartime bonus system, awarding 3 more cents hourly on every tenth day of service. By January 1919, overall rates jumped to 30 cents for new crewmen, with senior streetcar workers earning 40 cents hourly, plus overtime. Such rates exceeded Southern Public Utilities wage scales by two to five cents, reflecting Division 590's overall power. ${ }^{7}$

However, the economic problems that affected streetcar services during the Great War smoldered beneath Columbia's atmosphere of compromise. In November 1914, Columbia Street Railway lost nineteen cars in a barn fire. Although Camp Jackson

\footnotetext{
${ }^{6}$ This protective ordinance effectively blocked the deployment of strikebreakers in case of industrial action. Violators could be fined from $\$ 50$ to $\$ 100$ for each offense, or spend up to a month in jail for each violation. (Motorman and Conductor, August 1917, 24; The State, 25 February 1922, 1; Fetters, 46-47).

${ }^{7}$ Motorman and Conductor, October 1916, 14; January 1917, 9-11; February 1917 , 23; February 1918, 24; February 1919, 6-7.
} 
brought military passengers during the war years, general ridership began to slacken with the purchase of automobiles. Raising the car fare to seven cents, plus three cents for transfers brought the "proverbial wolf knocking at the door," according to transportation historian Thomas Fetters. Soon, Columbia Railway was in serious financial straits. Likewise, Division 590's post-war relationship with Columbia Railway, Light, and Gas Company deteriorated rapidly after $1919 .{ }^{8}$

In other Southern locales, street railway labor relations were more contentious. One salient example of wartime tensions exists in the Chattanooga Streetcar Strike of 1917. This event provides illustrations for the bitter divisions within the ranks of streetcar workers toward unionism. It also sets the immediate stage for the Piedmont campaign, as AASERE organizers began to re-orient their strategy in the western sectors of North and South Carolina. Chattanooga, known as the "Dynamo of Dixie," prided itself on its mountain location as well as its recent modernization, factors in common with the Carolina Piedmont. However, the same class conflict later inherent in the Piedmont prompted the Chattanooga streetcar workers to strike four times within twenty years. In Chattanooga, AASERE chapter Division 115 formed as early as August 1899. Chattanooga's union later reorganized into Division $715 .^{9}$

The AASERE sought to organize in Tennessee for the next two decades. Knoxville's Division 644 was chartered in September 1913, with Memphis's Division 713 following in July 1916. However, union recognition in Chattanooga faced

\footnotetext{
${ }^{8}$ Fetters, 45-50.

9 James B. Jones, Jr., "The Other Side of the "Dynamo of Dixie": Class Consciousness and Worker Solidarity in Urban Tennessee: The Chattanooga Carmen's Strikes of 18991917," Tennessee History Quarterly Vol. 52, No. 2. (Summer 1993), 98-112; Motorman and Conductor, March 1919, 15; Shaw, 3.
} 
unexpected resistance in 1899 and 1911, both times due to older streetcar employees' mistrust toward "foreign" union organizers. In this case, "foreign" meant labor organizers from the North. One senior Chattanooga Railway and Light (CR\&L) conductor, E.L. Mallicoat, outright scorned AASERE organizers, stating: "When we get ready for anyone else to show us how to run our personal business, we will send for him." Younger streetcar men, however, continued in their efforts to gain union recognition, through the maintenance of informal meetings and caucuses. Such a division between older and newer workers may reflect generational and political differences. ${ }^{10}$

During World War I, strikes occurred in 1916 and 1917, testing the resolve of AASERE Division 715. After Memphis trolley men staged a walkout in the summer of 1916, Chattanooga employees received a 7 percent pay raise to ensure loyalty. But CR\&L's July 1916 pay raise, based on seniority, tended to favor the anti-union segment. This action precipitated unrest among some of the company's 215 workers, and by midAugust, over 55 percent of CR\&L employees had signed union cards, according to AASERE organizer Chris Cline. Shortly thereafter, twenty employees were discharged for joining the union. Cline announced a strike on August 21, which eventually resulted in temporary recognition of Division $715^{11}$

Broken promises on the part of CR\&L management eventually led to a more serious strike in September 1917. Unrest and dissatisfaction simmered among the union members over wages, but under Chris Cline's distant guidance, Division 715 maintained the peace throughout the summer. In late August, CR\&L introduced new ticket machines, Rooke Automatic Fare Registers. Previously, conductors had collected fares

${ }^{10}$ Motorman and Conductor, January 1914, 14; July 1916, 13; Jones, 100.

${ }^{11}$ Motorman and Conductor, October 1916, 14; Jones, 101-2. 
by hand, marking their daily intake on a wall chart. The AASERE supported this innovative register for its labor-saving merits, but local conductors resented these devices as an implication of mistrust from their employers. Rumors also circulated about a company purge of union members. ${ }^{12}$

Several workers were fired for noncompliance or insubordination at the behest of CR\&L vice-president Von W. Hoover, a known foe of unionism. Thereafter, Hoover announced that the CR\&L would endorse an "open-shop" doctrine. Hoover subsequently dismissed officers of Division 715, which touched off a strike on September 7. Strikebreakers were deployed on the company streetcars while AASERE representatives met with Hoover. Since CR\&L workers were technically still under union contract, organizer Chris Cline declared the company in violation of its union contract. ${ }^{13}$

What resulted in Chattanooga remains one of the most violent and acrimonious strikes in the city's history. On the evening of September 7, union members and strikebreakers clashed in the streets, while union supporters vandalized twenty streetcars. No deaths resulted, but several injuries were reported on both sides. Two U.S. cavalry troops were called into Chattanooga to restore order. Chris Cline soon regained control over Division 715, counseling the union men to await arbitration. But many local businessmen, represented by the Chattanooga Manufacturers Association (CMA), suspected outside agitation from the IWW. First National Bank president C.A. Lyerly even accused the strikers of collaborating with Imperial Germany. U.S. Attorney Wesley

\footnotetext{
12 National Archives and Records Administration, U.S. Department of Labor, Mediation and Conciliation Branch, Box 111, In Re: Street Railway Strike Chattanooga, Tennessee (23 October 1917); Motorman and Conductor, September 1917, 17; Jones, 103.

${ }^{13}$ Motorman and Conductor, September 1917, 17; Jones, 103.
} 
T. Kennerly of Knoxville, Tennessee, looked into this allegation, but military investigators from nearby Fort Oglethorpe, Georgia, found no such connections. ${ }^{14}$

Federal arbitration efforts in Chattanooga began almost immediately after the September 7 riots. However, violent incidents still occurred on the streetcar lines. During one confrontation, a bystander suffered minor shotgun wounds after a CR\&L replacement fired at a band of union supporters attacking his streetcar. On September 23, Division 715 renewed its strike, staging a joint march with other unions, numbering about 2,000 workers. At Von W. Hoover's order, two CR\&L streetcars blocked the parade's path, triggering an outbreak of violence that left one brewery worker slain by a federal officer, S.O. Welch, acting as a strikebreaker. Welch later faced indictment for murder. Four companies of U.S. infantry restored order without further injury to the civilians, although one soldier was wounded in the process. Fort Oglethorpe received orders to dispatch machine-gun units to Chattanooga on the following day. ${ }^{15}$

Fallout from the strike hit the region's newspapers immediately. Opinions were polarized, with a very strong showing for the workers. While conservative editors railed against the specter of class warfare, Chris Cline turned the tables by accusing company vice president Von W. Hoover of acting like a German sympathizer. As a counterblast,

\footnotetext{
${ }^{14}$ National Archives and Records Administration, U.S. Department of Justice, Investigations on Labor, Box 117, Brown, Spurlock, \& Brown to U.S. District Attorney W.T. Kennerly (30 September 1917); Charles A. Lyerly to Attorney General Thomas W. Gregory (October 11, 1917); Headquarters Provost Guard, Fort Oglethorpe, to U.S. District Attorney W.T. Kennerly (20 October 1917); Jones, 106.

${ }^{15}$ National Archives and Records Administration, U.S. Department of Justice, Investigations on Labor, Box 117, Brown, Spurlock, \& Brown to U.S. District Attorney W.T. Kennerly (30 September 1917); Brown, Spurlock, \& Brown to Assistant Attorney General William C. Fitts (11 October 1917); District Attorney W.T. Kennerly to George D. Lancaster (October 1, 1917); District Attorney W.T. Kennerly to U.S. Attorney General Thomas W. Gregory (October 12, 1917); Jones, 108-9.
} 
CR\&L's chief attorney, George Lancaster, implored U.S. Attorney Kennerly to arrest Cline on a technicality that their client's streetcars sometimes conveyed U.S. mail shipments. This ploy had proven effective for both company and government officials during the 1893 Pullman Strike in Chicago. But Kennerly reasoned that CR\&L streetcars were private property, and no one could prove these vehicles were carrying mail during the vandalism of September. In any case, Kennerly asked both sides to restrain their hostilities until the Department of Labor had completed its negotiations. ${ }^{16}$

George Lancaster subsequently took the streetcar company's charges of IWW terrorism to Attorney General Thomas Gregory's office in Washington, where they were considered without much fanfare. Both Chattanooga Railway and the Chattanooga Manufacturer's Association pleaded for the Attorney General to enforce the "open shop." However, none of these mill and factory owners could prove connections with radical groups. Considering Gregory's role in establishing the Espionage and Sedition Acts of 1917, his office's lack of alacrity tends to disprove the CMA's charges. Gregory also used similar "anticipatory action" toward the 1917 Minneapolis streetcar strike. Throughout this time, one hundred and sixty-six members of the Industrial Workers of the World stood trial for sedition in Chicago, including their leader, William "Big Bill" Haywood. But nothing came of Chattanooga Railway and Light's efforts to link their striking workers to greater national, not to say global, events. ${ }^{17}$

\footnotetext{
${ }^{16}$ National Archives and Records Administration, U.S. Department of Justice, Investigations on Labor, Box 117, District Attorney W.T. Kennerly to George D. Lancaster (October 1, 1917); District Attorney W.T. Kennerly to Brown, Spurlock, \& Brown (11 October, 1917).

${ }^{17}$ National Archives and Records Administration, U.S. Department of Justice, Investigations on Labor, Box 117, George D. Lancaster to District Attorney W.T. Kennerly (October 2, 1917); U.S. Attorney W.T. Kennerly to Assistant Attorney General
} 
Chattanooga streetcar workers agreed to return to work on October 7, under CR\&L's “open shop" contract. Unfortunately, some streetcar workers resented the company's retention of ten African-American linemen who were suspected of being scabs. During this racially-charged era, whites often considered replacement by black workers as a personal insult. Despite Chris Cline's moderation, sufficient members of Division 715 were motivated to strike without warning on October 16. Following a court injunction, the strikers lost public sympathy, especially after one CR\&L streetcar exploded mysteriously on December 2. Even though most CR\&L workers had returned to the open shop by January 1918, their union - and way of life --collapsed quickly afterward. Chattanooga Railway and Light fell into receivership by 1922, as the rise of automobiles and motor-buses ended the city's history of streetcar transportation. ${ }^{18}$

Incidents such as the one in Chattanooga were a foretaste of what would come after the Armistice of 1918. Owing to public outrage over fare hikes, plus gradual increases in private car ownership, many transit enterprises went into receivership after the Great War. Fourteen percent of the nation's streetcar companies had fallen to receivers within one year of the war's end. While Southern Public Utilities avoided such a fate, exaggerated fears of nationalization proved useful to the company's anti-labor arguments in 1919 and beyond. Meanwhile, other regional traction corporations failed

W.C. Fitts (11 October 1917); Assistant Attorney General W. C. Fitts to U.S. Attorney W.T. Kennerly (13 October 1917); Von W. Hoover to Attorney General Thomas W. Gregory (18 October 1917); Jones, 109; Grubbs, 81-2; Millikan, 110.

${ }^{18}$ National Archives and Records Administration, U.S. Department of Justice, Investigations on Labor, Box 117, Von W. Hoover to Attorney General Thomas W. Gregory (16 October 1917) Motorman and Conductor, November 1917, 7, 17; Jones, 111. 
across the Carolina Piedmont region. Southern Public Utilities Magazine and its chief rival, Motorman and Conductor, both weighed in regarding the causes of this economic threat to their combined interests in streetcar transportation. However, as one might expect, the streetcar company and the union drew widely divergent conclusions. ${ }^{19}$

One popular cost-cutting measure employed by streetcar companies, the one-man streetcar proved more threatening to platform workers and streetcar operators than automatic cashiers. Motormen were gradually phased out in favor of conductors, who were thereafter expected to do both jobs. As one might imagine, the decreased work force and increase in responsibility did not please AASERE leaders, reflected by a campaign to discredit the one-man car's design and implementation. While Southern Public Utilities Magazine printed favorable editorials toward its use of one-man cars, Motorman and Conductor aired many complaints, especially during the immediate postwar period of 1919-21.

One editorial decried a massive advertising campaign in 1920 to replace all twoman streetcars with single-conductor models. The unsigned writer blamed poor behavior and indifference on the part of some conductors, but criticized the lack of two-man cars because single conductors tended to make more mistakes without a counterpart to watch out for them. ${ }^{20}$ Prophetically, Motorman and Conductor warned that one-man streetcars would encourage the traction companies to eliminate jobs and raise car fares. Another article warned that single-conductor streetcars were more prone to accidents, owing to the conductor being so busy making change and collecting fares. Without a motorman to

${ }^{19}$ Southern Public Utilities Magazine, Vol. 5, No. 6 (January 1920), 1-4.

${ }^{20}$ Motorman and Conductor, January 1922, 12. 
assist in braking, Motorman and Conductor asserted that streetcar accidents had increased nationwide from 1919-21. ${ }^{21}$

By January 1921, unions were strong enough in Detroit and Philadelphia to block use of single-conductor streetcars in their respective suburbs. Some cities, such as Minneapolis, only employed these models in downtown areas. However, many Southern cities, such as Mobile, Alabama found these new streetcars quite profitable. In the Carolina Piedmont, Southern Public Utilities introduced their first single-operator vehicles as far back as 1916. According to Loy Cloninger, his older brother, J.L. Cloninger, took charge of the first one-man car in Charlotte. Wartime labor shortages accelerated the need for faster, more efficient streetcars, especially after the establishment of Camp Greene, where SPU had built a terminal extension to serve hundreds of young officers and thousands of enlisted men visiting Charlotte during the weekends. ${ }^{22}$

By December 1918, the South Carolina town of Anderson had totally replaced their older two-man cars with newer models. Mayor Foster Fant believed that "no good end [could] be attained by a return to the old type of cars," while a local attorney, H.H. Watkins discounted complaints from larger cities, where loading and unloading passengers often required a motorman as well as a conductor. After the 1919 strike, Charlotte and Winston-Salem introduced "one-man safety cars," designed for safer stops and loading procedures. These went into effect in January 1920, with Dilworth predictably receiving the first improvements. Eight cars covered the First and Fourth Ward lines through Dilworth, with only five-minute layovers. Among the drivers selected for this new route were G.L. Cloninger and Jesse Ashe. Twelve other cars were

\footnotetext{
${ }^{21}$ Motorman and Conductor, January 1921, 7-8.

${ }^{22}$ Cloninger, 2-3; Mitchell and Perzel, 2-7.
} 
divided evenly between the Winston-Salem and Greenville lines. Proponents believed these one-man safety cars would save the electric streetcar industry. ${ }^{23}$

Instead, this measure merely staved off the inevitable decline, as new modes of transportation eclipsed the trolley. The proliferation of automobiles, taxis, and motorbuses, plus the advent of quasi-legal jitney services, all led to a decline in street railways. Moreover, as the automobile became a symbol of middle-class prosperity and perceived independence, streetcar suburbs and trolleys no longer had the same respectability they once enjoyed before the war. ${ }^{24}$

Throughout the immediate post-war year of 1919, the AASERE continued its nationwide campaign for national influence. Winning hearts and minds proved more difficult in the post-war Carolinas. Despite federal support and acknowledgement, the Amalgamated's recognition in traditionally hostile regions like the Carolinas still hinged upon boardroom decisions and public opinion. ${ }^{25}$ Isolated victories aside, the Carolina Piedmont remained unchallenged by AASERE organizers. Without an apparatus to link Asheville to Columbia, these gains would remain islands in a hostile sea. For a truly successful campaign, the union required more cities to organize their streetcar lines, creating a stronger regional network of disciplined municipal labor unions, capable of controlling emotional impulses, such as "wildcat" strikes and vandalism.

${ }^{23}$ Southern Public Utilities Magazine, Vol. 4, No. 12 (December 1918), 23; Vol. V, No. 3 (August 1919); Vol. V, No. 7 (December 1919), 31-32; Motorman and Conductor, Vol. 29, No. 2 (January 1921), 7-8.

${ }^{24}$ David J. St. Clair, "The Motorization and Decline of Urban Public Transit, 19351950," Journal of Economic History, (September 1981), Vol. 41, No. 3.

${ }^{25}$ Motorman and Conductor, Vol. 27, No. 4 (March 1919), 25. 
However, establishing such labor unions required compromises with utility corporations and traction companies that seldom were forthcoming. Throughout the country, many businessmen resisted organized labor, despite their contributions toward the war effort. Union memberships flourished during wartime, but new employer associations also proliferated. Chattanooga's Manufacturers Association had many counterparts across America, so-called "unions against unions." William Millikan used this term to describe professional strikebreakers in Northern industrial sectors such as Detroit and Minneapolis. However, Southern textile mills could also rely on professional strikebreakers who used intimidation, vandalism, and deadly force. ${ }^{26}$

As wartime cooperation with the government waned, corporations saw a grand chance to break the unions. As the nation's brief spurt of wartime productivity wound down, consumer prices skyrocketed. Congress prematurely ended price controls, further compounding the situation. Following the dissolution of the National War Labor Board in August 1919, corporations no longer felt obligated to negotiate over union recognition or wage increases. Under the so-called "American Plan," major corporations breathed new life into the old "open-shop" gospel, blaming unions for the economic downturn. As a lame duck, Wilson's wartime policies had already alienated conservative voters, evidenced by the Democratic Party's losses in Congress in November 1918. By late 1919, distracted by his physically exhausting battle for the League of Nations, Wilson seemingly placed less emphasis on the conditions of labor in America. ${ }^{27}$

\footnotetext{
${ }^{26}$ See William Millikan, A Union Against Unions (St. Paul: Minnesota Historical Society Press, 2001).

${ }^{27}$ Eliot Asinof, 1919: America's Loss of Innocence, (New York: Donald I. Fine, Inc., 1990), 114-25; Motorman and Conductor, Vol. 29, No. 1, (December 1920), 10; see also Gene Smith, When the Cheering Stopped, (New York: William Morrow), 1971.
} 
To be fair toward President Wilson, he did not totally ignore the plight of American workers as he strove for peace in Versailles. Labor Secretary William B. Wilson remained in contact with his chief executive, concerned about the "strained conditions" and anti-union hostility in the public transportation sphere. On May 15, President Wilson approved the creation of a Washington conference on the state of U.S. electric railways, moderated by John H. Pardee, presiding officer of the American Electric Railway Association. Given the receiverships and mounting strikes after the war, both the traction companies and unions feared their way of life would soon end. Delegates from investment banks, state commissioners, and the mayors' league shared the same table as union members, but notably missing were representatives from major street railway and utility companies. Perhaps the corporations sensed that not everything said in Washington that summer would be to their liking. However, Southern Public Utilities Magazine dutifully reported the proceedings, as did Motorman and Conductor. Both were very selective in their quotations from the proceedings and reports, adding choice editorial comments in regard to the speakers and their conclusions. ${ }^{28}$

This railway conference began on July 15, and lasted until August 11. Former President William Howard Taft spoke first. As Joint Chairman of the National War Labor Board in 1918, Taft described his official position as a neutral conciliator who settled industrial disputes without strikes or lockouts. Taft acknowledged the wartime authority of Congress to raise streetcar fares, usually regulated by state and local officials. While Taft felt the public had to make sacrifices in order to ensure labor's

${ }^{28}$ Motorman and Conductor, Vol. 27, No. 6, (June 1919), 6-8; Charlotte Observer, 10 August 1919, 3; Southern Public Utilities Magazine, Vol. 5, No. 3 (15 August 1919), 914. 
cooperation, he felt raising the car fares actually hurt consumers more than utility increases. Rates above seven cents would hurt consumers as well as businesses themselves. Since most traction companies were outgrowths of municipal utility corporations, Taft argued these businesses should find more equitable means of making up for their losses. On the subject of pay, he felt peacetime rates should be decided by the companies, but wages should not be decreased. ${ }^{29}$

Harlow Clark, editor of the American Electric Railway Association magazine, Aera, believed merely increasing fares would not restore lost credit. Operation costs were becoming more expensive by the month. Southern Public Utilities Magazine listed 48 companies in receivership during 1919 alone, with 53 U.S. cities already charging ten cents. While SPU blamed federal control during 1917-18 for beginning this decline in revenue, their own mathematical figures indicate these problems began as early as 1915 , when investment bonds tripled. In 1914, only 10 traction companies reported losses. But over the next year, 27 streetcar lines fell into receivership - two years before the U.S. entered the war. Moreover, 1909 through 1913 had also been poor years, with 1910 reporting over $\$ 75$ million in debts against $\$ 12$ million in profits. ${ }^{30}$

Other distinguished speakers weighed in concerning the solvency of streetcar services. Secretary of War Newton Baker, prior to his political appointment, had served under - then succeeded - Tom L. Johnson as Cleveland mayor during that city's disastrous 1908 street railway strike that led to Johnson's removal. Baker helped establish one of the first successful "service-at-cost" street railway systems - the Taylor

\footnotetext{
${ }^{29}$ Southern Public Utilities Magazine, Vol. 4, No. 8, (September 1918), 8-9, 13-16; Motorman and Conductor, Vol. 27, No. 6, (June 1919), 6-8.

${ }^{30}$ Southern Public Utilities Magazine, Vol. 5, No. 6, (November 1919) 1-4; Vol. 5 , No. 10, (March 1920), 4-5.
} 
Franchise. In practice, a company would put its entire property up for collateral in exchange for investments. Banks would risk 6 percent of the total property's worth in order to bolster the traction service. Fares were regulated depending on actual cost of operations, plus the 6 percent capital. This operational method appealed even to moderate conservatives like Taft, who believed "service-at-cost" could counter pleas for public ownership - viewed by many as one step removed from socialism. ${ }^{31}$

However not everyone in the ranks of labor shared the same enthusiasm for the Taylor Franchise. Motorman and Conductor, for example, believed that keeping fares at the lowest possible rate would also act as an incentive to keep employee wages at a similar level. Public ownership and profit-sharing enterprises appealed more broadly to AASERE members. One of the more cogent - and controversial - public ownership proposals became known as the Plumb Plan, named for its chief proponent, Glenn T. Plumb. Author of Industrial Democracy, Plumb represented labor organizations during the war, becoming a popular speaker at labor rallies. Plumb argued for the continuance of government management of railways, which popular historian Eliot Asinof later alleged "turned chaos into order." One New York City franchise expert, Delos F. Wilcox, told the Washington committee that continued municipal control, if not ownership, would be the only solution for saving street railways. By contrast, AFL leaders, including Samuel Gompers, feared this step would invite charges of Bolshevism. Gompers opposed endorsement of Plumb's proposal during the AASERE's June 1919

${ }^{31}$ Arthur E. DeMatteo, "The Downfall of a Progressive: Mayor Tom L. Johnson and the Cleveland Streetcar Strike of 1908," Ohio History 104 (Winter-Spring 1995), 24-41; Motorman and Conductor, September 1919, 6-8; Charlotte Observer, 10 August 1919, 3. 
convention. However, William Mahon changed his opinion toward public ownership and halfheartedly endorsed the Plumb Plan, perhaps as a gesture toward union solidarity. ${ }^{32}$

In August 1919, the Motorman and Conductor began featuring a subscription to the Plumb Plan League, proposing "railroads shall be managed by human beings for human beings," instead of solely for profit. Despite opposition to the plan, Samuel Gompers even consented to become its honorary president. Acting as a lobby for government ownership, the Plumb Plan League convinced lawmakers to incorporate the railway plan into the Sims Bill in late 1919. However, Plumb's proposal met with defeat during Congressional hearings in early $1920 .{ }^{33}$

The Lower Carolina Piedmont appears to have split over the question of public ownership for street railways. In one Columbia, South Carolina, newspaper, Frederick J. Haskin cited the period's high bankruptcy rates in public service companies as a "casualty of war." While Haskin did not begrudge the streetcar union's drive for higher wages, he lamented the companies being forced to raise their fares, prompting unpopularity among those citizens unable to afford cars. Haskin's solution to South Carolina's street railway crisis resembled the Plumb Plan in most particulars, except it relied upon state, rather than federal oversight. Charles Henry, editor of the Columbia Labor Advocate, deemed the Plumb Plan too radical for his tastes. However, he urged Railroad and Streetcar brotherhoods to propose a "more understandable and realistic" government plan. More indicative of the Upcountry's mood, newspaper editor Calvin

\footnotetext{
${ }^{32}$ McCartin, 203-220; Asinof, 155-56; Spartanburg Daily Herald, 14 August 1919, 1; Motorman \& Conductor, January 1912, 10.

${ }^{33}$ Even if the Sims Bill had become law, President Wilson's 1920 executive order ending government regulation of railroads would have likely overridden the decision. (McCartin, 203-220; Asinof, 155-56; Motorman \& Conductor, August 1919, 33).
} 
Hemphill of Spartanburg avowed total opposition to the Plumb Plan or "service-at-cost" franchises. Marrying labor radicalism to proposed federal control, one unsigned Greenville editorialist warned his readers to "get ready for a strike to force government ownership," because railroad labor organizations were prepared to use "other means" than persuasion. ${ }^{34}$

Most corporations, including Southern Power, printed refutations of government ownership in their company publications. Southern Public Utilities Magazine featured editorials from such notable anti-labor apostles as Boston governor Calvin Coolidge and Seattle mayor Ole Hanson. These impassive figures, like James B. Duke and his corporate lieutenants, were opposed to public ownership, as well as "service-at-cost" plans. After all, Duke's ventures had done pretty well during the war. Thus, Southern Public Utilities aligned itself against organized labor and post-war reforms. However, during the war years, SPU offered incremental pay raises to offset the increasing costs of living. Between October 1, 1916 and August 1, 1919, the company boasted an aggregate wage increase of more than 100 percent. Moreover, Taylor promised future pay increases for 1920, subject to revenue improvements. ${ }^{35}$

Initially, Southern Public Utilities streetcar workers did not openly question Taylor's economic arguments. Some of Taylor's men were perhaps swayed by a November 1918 appeal to "revival" among its workers. However, this same company editorial autocratically stressed servility and deference, traits which seemed out of place

34 Columbia State, 31 July 1919, 21; Columbia Labor Advocate, 15 August 1919, 4; Journal and Carolina Spartan, 7 July 1919, 4.

${ }^{35}$ Southern Public Utilities Magazine, Vol. 4, No. 1, (February 1918) 1-41-4; Vol. 4, No. 12 (February 1919), 9-10, Vol. 5, No. 1, (June 1919), 1-8; Vol. 5, No. 1, (August 1919), 28; Vol. 5, No. 11 (April 1920), 1-3. 
in a nation so recently devoted to battle for democracy. ${ }^{36}$ As post-war economic troubles mounted across the Carolina Piedmont, Southern Public Utilities streetcarmen and electricians commenced a quiet rebellion, which eventually led to open war with their employers by the summer of 1919 .

What conditions helped convince the streetcar workers of the PiedmontUpcountry to unionize? After the November Armistice, returning servicemen almost invariably found their prior jobs had been filled by men who did not serve overseas. Immediately, the AASERE launched campaigns to win veterans over to unionism, stressing trade unionism's altruistic motives toward war veterans. The Motorman and Conductor decried the "returned soldier problem" as a means for post-war "open-shop" exploitation. Indeed, many non-union manufacturing plants had closed down in late 1918 , rather than permit the return of unionized workers. When these factories reopened for a peacetime economy in 1919, they began hiring unemployed veterans at reduced wages, stressing "patriotic preference."37

Union rhetoric, however, only played a modest part in convincing Carolina Piedmont workers to organize. As a field ambulance driver who served in four Western Front campaigns, Jesse B. Ashe later admitted Southern Public's low wages had been a primary factor in his decision to join the streetcar union. To Zebulon Taylor's own credit, Southern Public re-employed some returning veterans, including Ashe. Even so, disappointment continued to foment unhappiness among many streetcar workers. Ashe,

\footnotetext{
${ }^{36}$ Southern Public Utilities Magazine, Vol. 4, No. 9-10 (November 1918), 34.

${ }^{37}$ Motorman and Conductor, August 1919, 2-3.
} 
at thirty-two years, still lived in a boarding house on short commons, with little hope of marriage, and even less hope for home ownership. ${ }^{38}$

After the war, an aura of quasi-militarism also seems to have penetrated Southern Public Utilities. Zebulon Taylor utilized wartime rhetoric against unionism, appealing to wartime duty and obligation on one hand, while simultaneously condemning union organizers as traitors. Uniformed streetcar workers competed in safety drill teams led by captains, first lieutenants, and second lieutenants. These teams were rewarded for their drills with cash rewards totaling over $\$ 1,000$; although the captains and lieutenants received most of the cash. Fifty-five streetcar employees boasted honorable service records, but perhaps not everyone enjoyed replicating Army life in the civilian sphere, especially now that their wartime duties were concluded. ${ }^{39}$

Union sickness benefits and widow relief programs may also have appealed to Southern Public workers in a decade punctuated by the Great Influenza. October 1918 brought the epidemic to Charlotte. Conductor A.T. Hamlet died of pneumonia after suffering from the virus. Over twenty other conductors and motormen reported illnesses, some affecting entire families. One SPU machinist, R.L. Crosby, tragically lost two of his three children to the rampant illness. Another employee lost a newborn son due to complications. Quarantines left most SPU workers short about two weeks of pay. Even as late as February 1920, several motormen still reported attacks of influenza. ${ }^{40}$

${ }^{38}$ Ashe interview, 3.

${ }^{39}$ Winston-Salem's SPU branch actually boasted one real Army officer, Captain Hampton S. Beck, who commanded a state National Guard unit. (Ashe interview, Southern Public Utilities Magazine, Vol. 5, No. 8, (January 1920), 33; Vol. 6, No. 10, (March 1921), 1-7).

40 Southern Public Utilities Magazine, Vol. 4, No. 9-10 (November 1918), 18-20; Vol. 5, No. 11 (April 1920), 1-3. 
By late spring of 1919, the South faced an unemployment crisis, with South Carolina suffering particularly hard times. Columbia and Spartanburg's streetcar employees were both adjudged poor in morale and efficiency by regional newspapers. Charleston reported about 400 unemployed industrial workers; in Columbia, more than 1,000 mill-hands and mechanics were out of work. Federal offices were so overwhelmed that they closed briefly during the summer. Spartanburg's Journal and Carolina Spartan further speculated that many unemployed workers were returning "Negro" veterans, who met with redoubled Jim Crow prejudices on their return from the Great War. Job competition fueled racial tensions. During one eighteen-month period, from January 1918 to June 1919, the Tuskegee Institute Records and Research Department reported seventy blacks lynched across the South. ${ }^{41}$

How did national trends, characterized by the "Red Summer" of race riots in Chicago, affect the Carolina Piedmont? Southern conservatives blamed racial conflicts on Bolshevik subversion. South Carolina progressives, like Richard Manning and James F. Byrnes, were not immune to such fears. Senator Lee S. Overman of North Carolina also saw putative connections between Bolshevism and race riots. Meanwhile, Ku Klux Klan activity increased in the Upper South. In June 1919 alone, South Carolina witnessed one lynching, while North Carolina reported two documented cases. ${ }^{42}$

\footnotetext{
${ }^{41}$ Some African-Americans found menial jobs with major employers like Southern Public Utilities, but most became low-paid sharecroppers or mill-hands; others embarked with their families on what became known as the Great Migration. (Journal and Carolina Spartan, 15 May 1919, 1; 5 June 1919, 1; Star of Zion, Vol. 43, No. 26, (17 July 1919), 4; Southern Public Utilities Magazine, Vol. 5, No. 3, (15 August 1919), 915).

${ }^{42}$ William M. Tuttle, Jr., Race Riot; Chicago in the Red Summer of 1919 (New York: Atheneum, 1970); David Mitchell, 1919: Red Mirage (MacMillan Company: New York, 1970); New York Times, 31 August 1917, 4; Edgar, 488; Asinof, 139; 154-55.
} 
Yet race played a surprisingly peripheral role in the Piedmont streetcar strikes, primarily because none of the employers brought in African-American replacements. White streetcar workers in the South zealously protected their jobs against so-called black "scabs," as evidenced by the conduct of Chattanooga workers in 1917. In New Orleans, African-Americans were able to qualify for conductor jobs, but this trend does not seem to have spread across the South. White shopmen and electricians openly supported the Southern Public Utilities strike of 1919, but no evidence suggests participation from black shopmen. Moreover, black mill workers did not show open sympathy for either Spartanburg or Columbia's streetcar strikes. If this had been the case, both corporations and newspapers would have described these situations in racial, rather than Red Scare, terminology. Moreover, returning black veterans had more problems than unemployment facing them. Blacks were outraged by conservative implications that they were witless tools of the Bolsheviks. One African Methodist Episcopal bishop, Charles H. Philips, stated in the Carolina Spartan that race riots, while detrimental to "peace and harmony," were independent from the Bolshevist revolution. One regional newspaper, the Star of Zion, claimed in "The Negro and Bolshevism" that "the Negro will be kept immune" from labor agitators once the issues of "lynching and burning" were resolved. ${ }^{43}$

Inevitably, white workers fared better than blacks, even during the post-war economic tailspin. North Carolina streetcar employees were listed on paper as improving economically due to wartime wages, averaging 48 percent increases by 1919 . North Carolina required all railway work shifts to match the Federal standard of eight hours. Union pay scales were encouraged for all employees, including textile mill hands.

${ }^{43}$ Star of Zion, Vol. 43, No. 26, (17 July 1919), 4; Vol. 43, No. 27, (7 August 1919), 3; Journal and Carolina Spartan, 14 August 1919, 4. 
However, such gains were seriously offset by cost of living increases, which averaged about 104 percent in North Carolina alone. Nationwide, food expenses had risen 84 percent since 1914, while clothing increased 114 percent. By 1920, Charlotte became the most expensive city in the Piedmont. Annual food costs for a Charlotte working-class family amounted to $\$ 772.20$, with average yearly rents at $\$ 45.07 .{ }^{44}$

Ultimately, American involvement in World War I did not last nearly long enough to seriously challenge longstanding social order in the "Solid South." While the Great War certainly expanded the growth of Charlotte and other Piedmont towns, peacetime meant business as usual. Historian David Carlton concludes that the future belonged to Piedmont industrial towns, with their vision of a "well-organized, rationallyrun" society. Fellow historian Allen Tullos echoes this perception, citing Duke Power's promotional literature distributed across North Carolina. Duke's answer to abject rural poverty in the Piedmont lay with the recruitment and urbanization of "racially pure" old pioneer stock, a Southern "yeomanry" unhampered by "un-American ideas."

Such language appealed to many Piedmont entrepreneurs, and it also resonated among white Protestant workers. While most laborers certainly desired better wages and prospects, many were swayed by arguments of company loyalty and local protectionism. Powerful, influential men capitalized on these workers' doubts by promoting their mistrust of federal interference and Northern labor agitation. From Spartanburg to Charlotte, these prejudices hardened during World War I, posing a challenge to the region's fledgling union chapters in 1919.

\footnotetext{
${ }^{44}$ National Industrial Conference Board, The Cost of Living Among Wage-Earners, Special Report Number 8, May 1920, 6-7; Thirty-Second Reports, 35, Asinof, 139.

${ }^{45}$ Carlton, 258-59; Tullos, 170-71.
} 


\section{Chapter 5: Grant Us a Contract}

In June 1919, the AASERE General Executive Board sent Albert Essex Jones to organize Spartanburg's street railway employees. Despite a decade of union leadership experience in Ohio, Albert Jones lacked regional knowledge of the South and knew even less about the people he sought to assist. Jones, widely perceived as an outsider to the Carolina Piedmont, now faced the challenge of winning Spartanburg's conservative leaders over to the side of organized labor. His arrival in Spartanburg augured a summer of labor controversy, beginning with Spartanburg's streetcar strike of July 1919.

Over the Fourth of July weekend, labor organizers from two chapters of the American Federation of Labor led a strike against South Carolina Light, Power, and Railways, a subsidiary of Southern Power's utility empire. This strike opened a wider regional dialogue on organized labor, encompassing textile, transportation, and electrical workers. A closer examination of the events in Spartanburg suggests the eventual rejection of labor unions in the Carolina Piedmont was never a foregone conclusion. Spartanburg's two newspapers, the conservative Journal \& Carolina Spartan and its progressive rival, the Spartanburg Herald, provide a gauge of sentiments, from outright scorn to cautious tolerance. Equally important, the Spartanburg strike triggered a bitter contest for the unionization of the region's most powerful corporate structure. Although James B. Duke remained elusive, his invisible hand still guided the larger events of Piedmont industry. Meanwhile, Duke's partner, Zebulon V. Taylor, watched the unfolding events at South Carolina Light, Power, and Railways with deep concern. 
Streetcar strikes were the last thing on Duke's mind that summer, as he quietly attended the third annual Southern Textile Exposition, held in Greenville. None other than his close ally, Benette E. Geer presided over this week-long event, just before the Spartanburg strike demanded his talents. In all, 40,000 attendees came to the recently unveiled Textile Exposition Hall. Southern Power funded much of the $\$ 225,000$ to build this structure, which included a huge auditorium and two levels for exhibitions. ${ }^{46}$

Benette Eugene Geer's participation in the Spartanburg strike is significant, principally because of his close relationship with James B. Duke and Southern Power. Little has been written about Geer, apart from L.M. Glenn's hagiographical treatment. As mentioned in the second chapter, Geer shared common business interests with Duke. But Geer also operated independently, evidenced by his leadership in the Cotton Textile Institute. This lobbyist organization sought to protect textile mill owners from regulatory efforts in Washington - just the sort of collective bargaining rights many Piedmont employers sought to deny their workers. ${ }^{47}$

Despite his alignment with the forces of capital, Geer also enjoyed a reputation for diplomacy and moderation that made his participation integral to a strike settlement. Geer would doubtless benefit from a prompt resolution of the transit deadlock because he owned Pacific Mills in Spartanburg, whose employees often relied on the SCLP\&R streetcars. As sitting president of the Spartanburg Commercial Association, Geer's influence could make or break the union's chances in the "City of Success."

\footnotetext{
${ }^{46}$ Southern Public Utilities Magazine, Vol. 5, No. 2 (15 July 1919), 18-20.

47 Journal and Carolina Spartan, 17 July 1919, 1; 17 July 1919, 8; Spartanburg Herald, 17 July 1919, 4, 8; Glenn, 31-33.

${ }^{48}$ Glenn, 31-33.
} 
Between 1910 and 1920, Spartanburg grew steadily from 17,517 to 22,638 inhabitants. Four major railroads converged at this Upcountry city, including Duke's Piedmont \& Northern electric railway. One factor in this railway hub's growth was Camp Wadsworth, but its impact was fleeting. Like many of the Southern military bases established during the Great War, Camp Wadsworth dried up following the Armistice. Nevertheless, its presence doubtless accelerated the Piedmont's urbanization. ${ }^{49}$

Spartanburg County's thirty or so textile mills had felt economic jolts throughout the war. Spartanburg, alongside Greenville and Anderson, launched South Carolina's textile industry during the $1880 \mathrm{~s}$. Converse Mill, one of the largest in the nation, began its eighty-year lifespan in 1892. Wartime contracts brought prosperity to mill owners, if not their workers. Spartanburg later benefited from the decline of Northern textile mills. Overproduction and labor disputes forced many mill owners to transfer assets to the Piedmont, renowned for its anti-union sentiment. For decades afterward, Spartanburg became known as the "Lowell of the South." Ten unincorporated mill towns orbited the county seat, connected by a series of roads, and significantly, trolley lines. ${ }^{50}$

\footnotetext{
${ }^{49}$ Most Spartanburg publications consist of priceless photographs and interesting reminiscences, but not much in the line of documentary research. (David Carlton, Mill and Town in South Carolina 1880-1920 (Louisiana State University Press, Baton Rouge and London, 1982); Archie Vernon Huff, Jr. and Archie Vernon Huff, Greenville: History of the City and County in the South Carolina Piedmont (Columbia: University of South Carolina, 1995); Vernon Foster, Spartanburg: Facts, Reminiscences, and Folklore (Spartanburg: Spartanburg County Foundation, 1998); Betsy W. Teter, Textile Town (Spartanburg: Hub City Writers Project, 2002); Caroll Foster and Mark Olencki. Spartanburg Revisited (Spartanburg: Hub City Writers Project, 2007); P.H. Norcross, Spartanburg, S.C. Report on Water Supply (Atlanta: Foote and Davies Company, 1924); Jonathan Brooke, Tent and Trench, Spartanburg County Historical Association, 2006, http://www.schistory.net/campwadsworth/contents.html, Internet, accessed 15 February 2008).

${ }^{50}$ Carroll Foster and Mark Olencki, Spartanburg Revisited (Spartanburg: Hub City Writers Project, 2007), 118; Betsy W. Teter, ed., Textile Town (Spartanburg: Hub City
} 
These trolley lines were owned and controlled by South Carolina Light, Power, and Railways (SCLP\&R). Originally the Spartanburg Railway, Gas, and Electric Company, this mid-sized corporation had managed for years to remain independent of Duke's Southern Power, operating twenty-one track miles leading from Spartanburg to the mill towns of Clifton, Glendale, and Saxon. This independent status changed after June 12, 1912, when SCLP\&R became a subsidiary of Southern Power in all but name. ${ }^{51}$

Franklin H. Knox (1864-1936), described by editor J. Calvin Hemphill as a "brass tacks booster," served as both general manager and senior vice-president for SCLP\&R. Originally from Pennsylvania, Knox remained a bachelor at age 55, living with his elder brother, William, who acted as company purchasing agent. Franklin Knox also backed Spartanburg community projects, such as a memorial park for fallen South Carolina soldiers. Usually well-liked by Spartanburg citizens, Knox could, nonetheless, be paternalistic toward his men, as well as contradictory in his public dealings with Spartanburg and the streetcar union. ${ }^{52}$

Doubtless, Knox expected many Spartanburg businessmen would share his opposition to labor unions. Foremost among these local leaders, J. Calvin Hemphill served as managing editor of the Journal and Carolina Spartan. Hemphill and his wife Rebecca lived in a rented townhouse located in the city's Second Ward. At 68, Hemphill represented "old" Spartanburg's views toward states' rights and organized labor.

Writers Project, 2002), 146-8; Carlton, 251-9. See also J.W. Simpson, Spartanburg City and Spartanburg County, South Carolina (Nashville, Tennessee: Brandon Printing, 1903).

${ }^{51}$ Clifton and Glendale were principal mill-towns northeast of Spartanburg. (Thomas T. Fetters, Palmetto Traction (Forty Fort, PA: Harold E. Cox, 1978), 91).

${ }^{52}$ Journal and Carolina Spartan, 5 June 1919, 8; 9 June 1919, 5; 3 July 1919; 12 July 1919, 1, 8; U.S. Bureau of the Census, 1920, Spartanburg County, Spartanburg, South Carolina. 
Hemphill had only recently crowed over labor leader Eugene V. Debs's imprisonment in Atlanta for protesting the war. Hemphill also praised hardliner mayors who forbade unions from congregating within city limits, comparing Spartanburg's John F. Floyd to the infamous Seattle demagogue, Ole Hanson. ${ }^{53}$

According to one Palmetto historian, South Carolina's city mayors at this time were endowed with the same powers as a police court magistrate. This authority governed the passage of town ordinances and declarations of emergency, placing Mayor John Floyd in a strong position of authority to block labor unions from meeting in Spartanburg - despite the fact such laws violated the Constitutional right to peaceful assembly. Floyd certainly had the wherewithal and clout to use such magisterial powers. During the Great War, Floyd also served as president of Spartanburg's Chamber of Commerce, negotiating valuable contracts for Camp Wadsworth. Floyd also had a reputation for strictness and forthrightness. However, given Mayor Floyd's reputation as a foe of organized labor, some of his gestures during the forthcoming strike reveal a more complex figure than Hemphill's description might lead one to expect. ${ }^{54}$

But not all in Spartanburg shared such prevalent anti-union views. Calvin Hemphill's rival, Charles Oscar Hearon of the Spartanburg Herald, took a somewhat different tone. Hearon, at age forty-one, represented the "new" South Carolina. Originally from Virginia, Hearon earned Spartanburg's respect for his tireless service, alongside Mayor John B. Floyd, as a major wartime booster for both Spartanburg and Camp Wadsworth. The Hearons owned a house on Marion Street, where the editor and

${ }^{53}$ Journal and Carolina Spartan, 9 April 1919, 4; 16 May 1919, 4; U.S. Bureau of the Census, 1920, Spartanburg County, Spartanburg, South Carolina.

${ }^{54}$ Vernon Foster, Spartanburg: Facts, Reminiscences, and Folklore, (Spartanburg: Spartanburg County Foundation, 1998), 341. 
his wife Belle raised four school-age children. His newspaper once advocated the "mutual advantage" of its long-standing relationship with Spartanburg's Typographical Union. Hearon's support for skilled laborers is well-documented, although his feelings toward the region's unskilled mill workers seem less clear. ${ }^{55}$

However, Charles O. Hearon consistently demonstrated Progressive values throughout the Spartanburg strike. The Spartanburg Herald stood for the public interest, which its editor held separately from business or labor concerns. Hearon also championed consumerism, efficiency, and public safety. While hailing Franklin Knox as a "considerate gentleman," Hearon criticized Spartanburg street railways as "one of the most unsatisfactory services in [this] city." Serving on the city council, Hearon had previously voted against the company's request for higher streetcar fares. Hearon's paper further cited the SCLP\&R's lack of progressive spirit, of good equipment, and of trained, well-paid men. Moreover, Knox's company had failed to yield annual profits except during the previous year, owing to traffic from Camp Wadsworth. Hearon further suggested a municipal study of the company's streetcar problems, in order to suggest reforms that would mutually benefit the company, its workers, and the public. ${ }^{56}$

By June 1919, the SCLP\&R's traction services in Spartanburg had become notorious for poor working conditions. D.L. Goble of the electricians' union spoke at the Temple of Justice on behalf of streetcar workers as well as electrical employees. ${ }^{57}$

${ }^{55}$ Brooke, Tent and Trench, chapter two; Spartanburg Herald, 4 July 1919, 1, 7; U.S. Bureau of the Census, 1920, Spartanburg County, Spartanburg, South Carolina.

${ }^{56}$ Charles O. Hearon later had a coastal defense station and a state park named in his honor. (Spartanburg Herald, 4 July 1919, 1, 7; History of Spartanburg County (Spartanburg: Works Progress Administration, 1940), 233-26).

57 Journal and Carolina Spartan, 16 June 1919, 2; 17 June 1919, 2; Fetter, 91. 
Goble, originally from Dallas, Texas, played a leading role throughout the campaign to mobilize trade unions in the Carolinas. On 16 June, he decried the treatment of the SCLP\&R's forty car-men, who were "treated worse than prisoners in any state." Goble attributed low worker morale to "speedups:" grueling twelve-hour shifts, for which a carman received no more than $\$ 24$ weekly. Nor was Goble alone in such condemnations. State Senator W.S. Rogers and local solicitor Ibra Blackwood gave their support to these statements. This convergence of organized labor and local opinion suggests that not every South Carolinian characterized unionization as the chief tool of Bolshevism. ${ }^{58}$

With thousands of visitors coming to the Piedmont, rebellious streetcar workers could prove an embarrassment to the region's power-brokers. In this tense atmosphere, the Amalgamated Association decided to launch its campaign to unionize the Piedmont and Upcountry transit workers. Several chapters had already been organized throughout the region, as noted in previous chapters. But streetcar workers in the South were especially hard hit by the ongoing economic slump, owing to low pay scales and hard hours. While the national Street Railway Commission in Washington still deliberated over possible reforms, hundreds of streetcar men across the Carolinas took encouragement from union leaders on the front lines.

One of these front-liners, Albert Essex Jones (1874-1962) figures prominently throughout Spartanburg and Charlotte's respective strikes. Jones had been a lifelong citizen of Cincinnati, Ohio, where he served as president of Division 627, which

${ }^{58}$ Ibra Blackwood later became the governor of South Carolina (1931-1935), whereupon he deployed the state militia against the 1934 Textile Workers strike, which he viewed as a "ruthless and insolent invasion." See Bryant Simon, A Fabric of Defeat: the Politics of South Carolina Millhands, 1910-1948 (Chapel Hill \& London: University of North Carolina Press, 1998), 115-119; Journal and Carolina Spartan, 16 June 1919, 2; 17 June 1919, 2. 
consisted of 400 conductors and 128 motormen. Twice married, Jones had lost his first wife, Irene, in childbirth. Remarried by 1917, Albert Jones's familial status and approaching middle age precluded him from military service. However, Jones's dedicated wartime union service earned him a promotion to Ohio's special organizer, responsible for preventing violent confrontations across the state. ${ }^{59}$

From available records, it appears that Jones was a sincere crusader for workingmen's rights, with a gift for oratory matched by a fierce combative streak. One whimsical picture from 1914 reveals a broad-shouldered, clean-shaven man in early middle age, posing next to a large doll meant as a contest prize for Cincinnati Street Railway's employee picnic. Yet underneath such humor and generosity, Jones also had a quarrelsome side. In September 1917, a local rival questioned Jones's integrity as Division 627 president. A quarrel ensued between the two union members, requiring the intercession of a special committee of peers, which promptly exonerated both litigants. Such a penchant for controversy could not have improved Albert Jones's standing in Cincinnati. By early 1918, Jones had left his union chapter to become a full-time organizer, coordinating a new union chapter in Columbus, Ohio. Shortly afterward, the AASERE sent Jones to aid new organizations in the Appalachian and Piedmont regions. ${ }^{60}$

${ }^{59}$ One such clash with armed strikebreakers took place in Lima, Ohio during the fall of 1917, claiming one union member's life, and wounding two other protestors in the fray. (Motorman and Conductor, Vol. 22, No. 8 (August 1914), 28; Vol. 23, No. 8 (July 1915), 24; Vol. 23, No. 10 (September 1915), 20-21; Vol. 25, No. 10 (September 1917), 24; U.S. Bureau of the Census, 1900, Cincinnati, Ohio; U.S. Bureau of the Census, 1910, Cincinnati, Ohio; U.S. Bureau of the Census, 1920, Cincinnati, Ohio).

${ }^{60}$ Motorman and Conductor, Vol. 22, No. 8 (August 1914), 28; Vol. 23, No. 8 (July 1915), 24; Vol. 23, No. 10 (September 1915), 20-21; Vol. 25, No. 10 (September 1917), 24; Vol. 26, No. 8 (July 1918), 16. 
In late June, Albert Jones conferred with C.E. Diltz, spokesman for the aggrieved SCLP\&R workers. Resultantly, Division 897 of the AASERE formally drafted its charter on June 25, 1919, with H.E. Sitton serving as first president of the Spartanburg chapter. ${ }^{61}$ Nevertheless, Franklin Knox considered this union's charter as an act of disloyalty. During the third week of June, the company director fired one worker, R.L. Kitchins, on charges of union activity. But if Knox had hoped to make an example to discourage unionization, he instead created yet another grievance among his workers. During the first round of negotiations on July 1, 1919, Kitchins's co-workers requested that Knox reinstate the discharged man at his prior level of seniority. ${ }^{62}$

Spartanburg's transit workers officially declared a strike at midnight on July 2 , after their first negotiation with Knox failed to yield concessions. Chapter 897 sought a new wage scale of thirty-seven cents to forty-one cents hourly, depending upon seniority. Workers had also requested a nine-hour shift to replace grueling "speedups" lasting eleven and a half hours. These terms were quite modest compared to suggested federal standards. President John Pardee of the American Electric Railway Association argued in Washington for overall pay hikes of one hundred percent in order to encourage striking workers to return to their cars. ${ }^{63}$

The sticking point, however, lay with Knox's staunch refusal to officially grant his workers the right of collective bargaining. On this point, Knox characteristically masked his iron resolve behind cautious, sometimes ambiguous statements. On the

\footnotetext{
${ }^{61}$ Motorman and Conductor, Vol. 27, No. 8 (July 1919), 12, 18; Motorman and Conductor, Vol. 27, No. 11, October 1919, 140.

62 Journal and Carolina Spartan, 3 July 1919, 7.

${ }^{63}$ Journal and Carolina Spartan, 3 July 1919, 1; Charlotte Observer, 15 August 1919, 9.
} 
strike's first day, Knox told Journal and Carolina Spartan reporters he would not recognize "forced demands" from labor unions. However, Knox offered to eliminate "split runs" in favor of two nine-hour shifts per day. Union members described this concession as one of Knox's longstanding promises that he had never honored. On July 3, Knox replaced his striking motormen with new recruits and transferred personnel from the sheds. Maintenance crewmen were not covered by AASERE, so they were under no expectations to strike. But there were too few remaining skilled men to staff the streetcars in operation for the Fourth of July. Knox's streetcar foreman and freight manager had already joined the union. Eight more workers defected to Division 897 over the weekend. While Knox took a brief vacation, only three trolley-men were available for work. Since Knox could not run streetcars anyway, he pointedly gave these "loyal" workers the day off. ${ }^{64}$

Division 897 did not take this snub lightly. A.E. Jones stated publicly that the Amalgamated did not intend to attack business outright. Instead, his organization sought to compromise with the company on behalf of workers. He stated that his union's goal was a "fair living wage" for each one of its members. South Carolina's Central Labor Union, a federation of local trade unions, endorsed Division 897. According to the Journal and Carolina Spartan, many Spartanburg citizens either walked or got a lift during the Independence Day celebration. ${ }^{65}$

One form of blue-collar protest against the streetcar company developed out of necessity. The Spartanburg Herald noted the use of "jitneys" to convey workers to their jobs. Such impromptu car-pools might remind present-day observers of municipal "ride-

${ }^{64}$ Journal and Carolina Spartan, 3 July 1919, 1, 7; 4 July 1919, 1.

${ }^{65}$ Journal and Carolina Spartan, 4 July 1919, 7. 
share" programs. Strike sympathizers across the United States often rode "jitney" transports to boycott streetcar lines raising their fares or employing "scab" replacements. In several cases across the United States, transit corporations and private citizens actually filed injunctions against such activities, citing a spike in traffic accidents. ${ }^{66}$

Unfortunately for Spartanburg County, the SCLP\&R's inter-urban lines only connected to three communities: the unincorporated mill towns of Clifton and Glendale, as well as the incorporated town of Saxon. Eight other mill towns in the county at large were not serviced by the SCLP\&R, so their interest in the strike would have been minimal at best. Thus, the actual impact of jitney travel on the Spartanburg strike of 1919 is difficult to ascertain. Nonetheless, textile mill workers comprised the vanguard of strike sympathizers during the AASERE campaign of 1919-22. ${ }^{67}$

The two main - and rival - city newspapers reacted promptly to the forced cessation of streetcar service. J.C. Hemphill of the conservative Journal and Carolina Spartan preferred compromise to confrontation, and suggested that shift changes would improve both public safety and employee morale. However, the editor doubted whether the SCLP\&R could afford any government-mandated wage hike - Hemphill neglected to mention that federal standards were far higher than the modest rates expected by the Spartanburg car-men. Hemphill vehemently remained opposed to all reforms smacking

${ }^{66}$ Spartanburg Herald, 6 July 1919, 1, 2; Robert H. Babcock, "'Will You Walk? Yes, We'll Walk': Popular Support for a Street Railway Strike in Portland, Maine," from Labor History, Vol. 35, No. 3 (Summer 1994); Elijah L. Robison, "The Streetcar Strike of 1916-17: 'Scabs,' Conspiracies, and Lawlessness in Springfield, Missouri," from Greene County Archives (Bulletin No. 67), Springfield, Missouri, 2004.

${ }^{67}$ A.A. Gerald, president of Columbia Division 590, also served in South Carolina Legislature, where he supported textile mill concerns as part of his constituency. See Motorman and Conductor, Vol. 30, No. 11 (October 1922), 9. 
of government oversight or state ownership, such as the aforementioned Plumb Plan. ${ }^{68}$ Hemphill's subscribers did not unanimously agree with his sentiments. On July 6, his newspaper printed a caustic letter from R.E. Tillotson, an employee of the Southern Railways Company. Tillotson voiced frustration toward loyal SCLP\&R workers who remained on the job. He also addressed the company's refusal to recognize the local streetcar union, characterizing "Mister Knocks" as the opponent of labor. Although Hemphill did not deign to comment, the Journal and Carolina Spartan held fast throughout the strike. ${ }^{69}$

Charles O. Hearon's Spartanburg Herald took a more tolerant approach toward labor. As previously mentioned, Hearon's newspaper operated in conjunction with Spartanburg's local typographical union. Correspondents interviewed streetcar workers who revealed that Knox had fired several employees who had asked for back pay. These men did not identify themselves, most likely over the real possibility of blacklisting. Hearon also criticized Mayor John Floyd for his perceived indifference to the strike. But Floyd, whose anti-labor reputation we have already noted, deliberately chose to take neither side in the dispute. Spartanburg's mayor also noted that if SCLP\&R failed to run their streetcars within nine months, the company would violate its franchise with Spartanburg and go out of business. Floyd also praised the orderly conduct of both strikers and company men. City policemen reported only one incident over the holiday weekend, wherein a strikebreaker swore at two local citizens for calling him a scab. The city government fined this replacement worker $\$ 5.85 .^{70}$

\footnotetext{
${ }^{68}$ Journal and Carolina Spartan, 7 July 1919, 4.

${ }^{69}$ Journal and Carolina Spartan, 6 July 1919, 4; 7 July 1919, 4.

70 Journal and Carolina Spartan, 5 July 1919, 1; Spartanburg Herald, 6 July 1919, 4.
} 
In this manner, the Spartanburg Streetcar strike affected the city for an entire week, with virtually no streetcar service throughout the city. Calvin Hemphill opined that the strike had become "more of an annoyance than a real problem." But the editor also warned union members that the public grew tired of the dispute. Charles Hearon's column, entitled “Can't We End This Strike?" urged the members of Division 897 to give their company president's proposals another chance. Hearon felt that the streetcar union, reliant upon "out of town" leadership, held the weaker position. Therefore, the editor further exhorted the strikers to face reality by placing the public interest first in priority. ${ }^{71}$

On the evening of July 10, Mayor John Floyd made a public-minded gesture of his own, by openly visiting Division 897 president H.E. Sitton, convalescing at home with appendicitis. Despite his anti-labor reputation, Floyd seems to have understood the need for mediation. Sitton and Floyd promptly scheduled a second conference for the next day, bringing company and union representatives to the bargaining table. ${ }^{72}$

On July 12, Floyd and Knox met with AASERE organizer Jones and local union president H.E. Sitton. Knox refused to acknowledge Jones as a spokesman, but offered Sitton a new wage schedule that the company established for replacement workers over the previous week. Knox conditionally agreed to implement nine-hour workdays, as personnel would permit, but would not budge on collective bargaining. Knox also pointedly refused to reinstate the discharged worker, R.L. Kitchins. This meeting

\footnotetext{
${ }^{71}$ Journal and Carolina Spartan, 11 July 1919, 4; Spartanburg Herald, 11 July 1919, 4.

${ }^{72}$ Journal and Carolina Spartan, 11 July 1919, 4; Spartanburg Herald, 11 July 1919, 4.
} 
concluded without any progress, as lines began to harden between Knox and his disgruntled employees. ${ }^{73}$

Following this round of negotiations, Jones openly praised the mayor for "using his good offices" on behalf of the public trust. The organizer asserted that Floyd had caught the company president in a prevarication during the hearings. Knox had given one set of terms to Mayor Floyd during the preceding week, but his actual terms on July 12 were substantially different. The SCLP\&R's new wage scale did not equal the first offer Knox made prior to the strike. Moreover, in this new contract proposal, overtime wages and "time-and-a-half" guarantees were dropped altogether. ${ }^{74}$

These discrepancies fostered an atmosphere of mistrust throughout the summer. Jones further commented on Knox's past record, stating that his promises "looked very rosy, but never materialized." His fellow workers could not "sell their lives and very existence without the scratch of a pen to protect them." Jones reminded Knox that his "personal feelings" alone could not support families, and implored him to "grant us a contract ... and we will start your cars before the ink is dry." If Knox persisted in his hostile course, Jones warned, "then [your] men will never operate them again."75

Despite Jones's forthright vow, Knox continued to reject the mayor's requests for compromise with his striking workers. Nor would the company recognize national labor organizations such as the AASERE. Charles Hearon made a very perceptive summation

73 Journal and Carolina Spartan, 12 July 1919, 1.

74 Journal and Carolina Spartan, 12 July 1919, 1, 8. We can assume Knox communicated with other traction companies and utility corporations. He might have been under pressure not to cave in to labor demands, because if SCLP\&R made concessions, then other locals would demand the same of other companies. This is borne out by the fact that after SCLP\&R settled the strike, Southern Public Utilities raised employee wages in an effort to forestall a similar strike in Charlotte.

75 Journal and Carolina Spartan, 12 July 1919, 1, 8. 
in his editorial on July 12. "In this present controversy," the Herald editor observed, "unionism will rise and fall by the fate of the demand that the union be recognized." Hearon also asserted that organized labor hitherto had failed to make headway in Southern states because "individualism... pride of family... and freedom of action" prevailed in their culture. But while "the average Southerner can take care of himself without organizations," the Spartanburg Herald also speculated whether "increased industry [in the South] may well require better acceptance of organized labor.,"76

Spartanburg's now week-long transit strike subsequently drew the attention of Governor Robert Archer Cooper (1919-22). Cooper had recently succeeded Richard I. Manning, but unlike his predecessor, the Laurens County native had not yet faced a serious labor dispute in South Carolina. The incoming governor, while expressing empathy for "the man who toils," failed to delineate his policy toward organized labor or collective bargaining. Governor Cooper roundly condemned "Bolshevism, anarchy, and commercial greed." His remedy for these post-war evils lay with the "spirit of sacrifice and disinterested purpose" which he believed had guided the nation during wartime. ${ }^{77}$

More significantly, while Cooper called for "improved transportation facilities," he did not imply public transportation, but private autos. Highway constructions derived from state taxpayers became a hallmark of Governor Cooper's two terms. As later chapters will elucidate, Cooper's road initiatives directly affected South Carolina's public

\footnotetext{
${ }_{77}^{76}$ Spartanburg Herald, 13 July 1919, 4.

${ }^{77}$ First Inaugural Address of Robert A. Cooper, Governor to the General Assembly of South Carolina (Regular Session, 21 January 1919) Columbia, S.C., Gonzales and Bryan, State Printers, 1919; Second Inaugural Address of Robert A. Cooper, Governor to the General Assembly of South Carolina (Regular session, 18 January 1921) Columbia, South Carolina, Gonzales and Bryan, State Printers, 1921.
} 
opinion toward traction corporations as well as transit workers. But, in July 1919, Governor Cooper had a full-blown labor-capital crisis on his hands. ${ }^{78}$

As a progressive, Governor Cooper favored conciliation between the company and union, which he promised to oversee personally in Spartanburg if the situation failed to improve. Several citizens' groups with connections to Cooper had already registered their concerns with the governor's office. Given the potential disruptions in textile mill production and public commerce, such opinions were not to be idly ignored. Moreover, since South Carolina's establishment of a conciliation board in 1916, the state legislature had also granted wide subpoena powers to its governor-appointed arbitrators. Cooper's statements came as a surprise to the major principals of Spartanburg's transit strike, who quickly resumed their conference on July 13. During the negotiation, Knox proceeded to restore partial streetcar services by using his replacement workforce. ${ }^{79}$

This fateful decision carried some consequence, as striking workers could lose their jobs to these alleged "scabs." Knox's replacements appear to have been a mixture of loyal company men and new hires. The SCLP\&R could not likely employ professional strikebreakers, trained more for intimidation than for industry. Nonetheless, the company expected opposition from strike sympathizers, if not the strikers themselves. On July 13, Superintendent B.A. Buckheister, Knox’s second-in-command, armed his streetcar crews with concealed handguns from an undisclosed private arsenal. ${ }^{80}$

78 Ibid.

${ }^{79}$ Journal and Carolina Spartan, 13 July 1919, 1, 9; Spartanburg Herald, 13 July 1919, 1, 5.

${ }^{80}$ Journal and Carolina Spartan, 16 July 1919, 1, 8; Foner, History of the Labor Movement, Volume VII, 202-203. 
Subsequently, three SCLP\&R streetcars returned to the lines. Initially, no troubles arose from local strike sympathizers or union men. But ill will gathered against union membership, as reported in the Greenville Daily News. One unnamed correspondent attacked Jones as a "rank outsider," who was bent on "making trouble between employer and employe[e]." This critic of the Amalgamated Association also referred to the organizer's opening speech in Spartanburg, insisting that because Jones "gave [SCLP\&R] the business," he should be "run out of town as a nuisance." Significantly, this writer did express his support for a local streetcar union, but argued that it should answer to the community, not outsiders. This unsigned editorialist likely meant either a company union, or perhaps a local employee representation plan, divorced from Northern, ergo "foreign" ties. ${ }^{81}$

As a so-called "foreigner," Albert Jones did take considerable risks entering a city like Spartanburg, with its reputation for hostility toward union agitators. Just three years before, Ben Commons, one of the AASERE's regional vice-presidents, suffered bodily injury in Memphis, Tennessee. Streetcar workers in Memphis had just endured a lockout over union recognition. Company strikebreakers assaulted the visiting union officer shortly after his arrival on June 27,1916 , openly striking him in a restaurant. In the presence of Memphis policemen and a court justice, the Memphis company superintendent then warned Commons his assailants "would get him if he did not leave town." Subsequently, one of Ben Commons' escorts suffered serious injury from a blackjack-wielding ruffian, who was arrested and promptly released on bail. ${ }^{82}$

${ }^{81}$ Greenville Daily News, 10 July 1919, 1; Journal and Carolina Spartan, 13 July $1919,4$.

${ }^{82}$ Motorman and Conductor, Vol. 24, No. 8 (July 1916), 13, 16-17. 
However, negotiations among Knox, Jones, and Floyd remained peaceful. Despite any inconveniences, Spartanburg's citizens could claim their town was working far better to resolve its labor strikes than Macon, Georgia. Both newspapers covered Macon's streetcar strike, wherein 180 employees struck for wages, briefly paralyzing the entire Georgia city. Neither editor wanted the same conditions to emerge in Spartanburg. Charles Hearon praised his own city government's "square-dealing" efforts to find a balance between company revenue and worker wages. ${ }^{83}$

By July 14, the situation improved enough for the company to add a fourth car to service, even though Knox's new motormen were inexperienced. Countywide rumors of greased tracks and derailed cars proved false, and no acts of violence were as yet reported anywhere in Spartanburg. Perusal of Spartanburg County's criminal records indicates a spike in malicious damage arrests in June and July of 1919, but case details remain terse. Police officers seemed more concerned with prohibition violations and morals charges. While eight cases of criminal assault and battery were reported in July, none of these were connected with the streetcar lines outside Spartanburg. Therefore, one can surmise that the ensuing violence of July 15 did not spread to the nearby textile mill towns. ${ }^{84}$

On July 15, just before $6 \mathrm{pm}$, the first blows were exchanged aboard SCLP\&R's Streetcar 32. One hothead, Grady LeMaster, forcibly attempted to remove a replacement conductor from his post. Both men were arrested for causing the affray, whereupon strikebreaker C.E. Edwards revealed that he was carrying a concealed handgun issued by Superintendent Buckheister. Edwards and LeMaster paid their bonds, $\$ 66.50$ and $\$ 15.75$

${ }^{83}$ Journal and Carolina Spartan, 15 July 1919, 1; Spartanburg Herald, 15 July 1919, 4.

${ }^{84}$ Spartanburg County Criminal Cases, Alphabetical Session Index (1909-59), (Roll SP52), South Carolina Historical Archives. 
respectively and went before Mayor Floyd to hear his verdicts. Under Spartanburg's city statutes, mayors exercised the same powers as a magistrate within city limits. Floyd's decision to uphold the company's right to issue firearms came as no surprise to those who knew his views. LeMaster's actions vindicated everything opponents of labor associated with unionism. While Floyd did not hold the streetcar union accountable for LeMaster's actions, he ruled that C.E. Edwards had the "same right as a constable" in the line of his duty. Although concealed weapon charges held a higher penalty than brawling, the mayor nonetheless fined the strike sympathizer, Grady LeMaster, $\$ 100 .{ }^{85}$

Worse violence occurred that same evening at Pine and Main Streets when another streetcar returned to its barn. Local demonstrators halted the car and demanded to know if the operator or his two bodyguards were union supporters. One of the strikebreakers, J.L. Brown, brandished a firearm, and fisticuffs ensued between the two opposing groups. C.C. Crouch, the motorman on duty, was a fifteen-year employee who had refused to strike on July 2. He suffered serious injuries and required hospital treatment. Interviewed later in his hospital room, Crouch could only vaguely identify his attackers as "union men." Whether these unionists were Crouch's former co-workers remains unknown. But Hemphill's editorial on 16 July implored the streetcar union to find and "turn out" Crouch's assailants. ${ }^{86}$

Three Spartanburg policemen promptly arrested J.L. Brown for carrying a concealed handgun. In the meantime, Superintendent B.A. Buckheister arrived on scene, brandishing his own firearm. Officer Jack Alverson arrested Buckheister as well. Mayor

\footnotetext{
${ }^{85}$ Journal and Carolina Spartan, 16 July 1919, 1, 8.

${ }^{86}$ Journal and Carolina Spartan, 16 July 1919, 1, 4, 8; Spartanburg Herald, 16 July 1919, 1, 5.
} 
Floyd acquitted the company official subsequently on precedents set by his July 15 ruling for C.E. Edwards. Since SCLP\&R employees were entitled to carry arms "as a constable," Buckheister's case was clear, at least in Mayor Floyd's eyes. Despite claims from witnesses who saw Buckheister draw the handgun from his coat, the superintendent firmly insisted that he had carried his gun openly, as he had expected trouble at the carbarn. Buckheister also threatened to charge his accusers with inciting the previous evening's riot. ${ }^{87}$

Vandalism escalated during the evening of July 15. Police cars drove to South Church Street to remove one automobile blocking the trolley line. Edward Wooten was arrested for placing bricks upon the tracks and later fined. Hundreds of townsfolk congregated following the incidents, but apart from the exchange of angry words, no further violence ensued. The mayor subsequently stationed a police officer on each operational streetcar. Incidentally, one plainclothesman, Moss Hayes, registered strong objections to the use of police to guard company property, resigning after 15 years with the Spartanburg police. Evidently, some policemen at least sympathized with the local union. But Hearon's newspaper later castigated the disobedient Hayes for "setting a dangerous precedent." ${ }^{88}$

Undoubtedly, these problems convinced Governor Cooper to become personally involved in the local Spartanburg strike. He appointed a mediation committee and mobilized fifty South Carolina reserve troops from Company F of the "Spartan Rifles." Another military reserve company from Greenville remained on stand-by in case of

${ }^{87}$ Journal and Carolina Spartan, 16 July 1919, 1, 8; 17 July 1919, 8. Evidently, Buckheister's alleged open carry of a handgun was interpreted as being legal.

${ }^{88}$ Journal and Carolina Spartan, 16 July 1919, 1, 8; 17 July 1919, 8; Spartanburg Herald, 17 July 1919, 4, 8. 
emergency. Despite rumors of steam-plant sabotage, there were no more incidents. However, streetcar services were suspended until a compromise could be reached. ${ }^{89}$ How did these small tremors of violence affect public opinion toward the AASERE? Hearon pleaded for "sanity and resourcefulness" from all sides in the controversy. Furthermore, he warned that the union would lose "public sympathy" if recent incidents were to multiply during negotiations. Perhaps, Hearon reasoned, the newly formed Spartanburg Commercial Association could "take the helm" of arbitration and thus avoid reliance on Governor Cooper's intervention. ${ }^{90}$ This suggestion appears consistent with local sentiments emphasizing independence and self-reliance in the face of any outside interference. Moreover, Spartanburg did not want to experience a military intervention, such as those witnessed in the recent textile strikes at Greenville and Anderson. While Governor Cooper had mobilized a token force, he preferred diplomacy as well. ${ }^{91}$

On the evening of July 17, Governor Cooper convened a board consisting of five labor representatives, five company spokesmen, and twelve South Carolina arbitrators. Governor Cooper remained in Spartanburg as an observer. Jones and Sitton directed the labor contingent, while Knox voiced company concerns. Benette E. Geer, president of Spartanburg's Commercial Association, led the final negotiations. For several hours, Geer's committee reviewed two contract proposals, one from each side. ${ }^{92}$

${ }^{89}$ Journal and Carolina Spartan, 16 July 1919, 1, 8; 17 July 1919, 8; Spartanburg Herald, 17 July 1919, 4, 8; Greenville Daily News, 17 July 1919, 1.

${ }^{90}$ Spartanburg Herald, 16 July 1919, 4.

${ }^{91}$ David Carlton, Mill and Town in South Carolina 1880-1920 (Baton Rouge and London: Louisiana State University Press, 1982), 258-59.

92 Journal and Carolina Spartan, 17 July 1919, 1; 17 July 1919, 8; Spartanburg Herald, 17 July 1919, 4, 8; Glenn, 31-33. 
Geer walked a delicate line as chief arbitrator. As a major Upcountry booster, with manufacturing interests, he seems an unlikely champion of unionism. Moreover, Geer had clashed with Governor Cooper's predecessor, Richard I. Manning, over state mill reforms. On the other hand, Geer likely wished to resolve the city's streetcar crisis quickly before unionism spread to other segments of the Piedmont's working class. ${ }^{93}$

Under pressure from the Spartanburg Commercial Association, Knox agreed to reinstate all striking employees, provided these men swore under oath they had no involvement in the July 15 disorder. This new contract also retroactively covered R.L. Kitchens, the union activist who had been discharged prior to the strike. Knox also promised a review process for employees and a wage schedule matching the union's earlier demands. Senior employees would earn 42 cents hourly after five years of service. Furthermore, Knox promised to organize two nine-hour shifts by August 15, and offered vacation days amounting to seventy-two hours each quarter. ${ }^{94}$

However, Knox's agreement did not reflect a capitulation on the subject of union recognition. Knox permitted his men to form local unions as long as they promised to remain loyal. But Division 897 still lacked official standing. Recognizing Knox’s ambiguous terms as the best possible settlement, Jones agreed, as did the local chapter president, H.E. Sitton. Public reaction to this settlement proved reassuring, as Spartanburg citizens began riding the trolleys once again. ${ }^{95}$ Despite relatively minor incidents of hostility, Spartanburg had resolved its transit strike largely on its own terms.

\footnotetext{
93 Glenn, 31-33.

94 Journal and Carolina Spartan, 18 July 1919, 1, 8; Spartanburg Herald, 18 July $1919,1,5$.

95 Ibid.
} 
While the AASERE did not gain outright legitimacy, its successful efforts on behalf of car-men were viewed as a potential threat to local authority. Spartanburg's two major newspaper editors did not conceal their dislike of "outside interference" from either the state government or the AFL. Despite the governor's decisive and careful use of state power, neither newspaper credited Cooper with hastening the resolution of July 17, nor did they even mention him by name. Hearon did congratulate the Spartanburg Commercial Association and praised both Knox and Sitton. Moreover, neither newspaper gave favorable coverage to AASERE's organizer, Albert E. Jones. Hemphill did make a sarcastically oblique reference to "imported talent" and suggested that local unions could resolve their problems without such "outside sympathizers." Yet, Hemphill's Carolina Spartan conceded Knox's initial hesitance to compromise had brought public "ill will" against the SCLP\&R. Greenville's newspaper issued a call for "compulsory arbitration" in all future strikes. But after two weeks of the "hottest and sloppiest weather [in] the season," Spartanburg could move forward. ${ }^{96}$

By July 19, Division 897's streetcar men were back on the job. Newspapers reported some friction on the first day, as old employees were not always returned to their usual positions. Knox promised to uphold the contract he had signed but also explained that changes would require patience and time. ${ }^{97}$ Shortly thereafter, local papers turned toward rising utility prices and race riots, two reigning news issues of post-war America.

Emboldened by his unexpected success in Spartanburg, Albert Essex Jones traveled to Charlotte, where Knox's concessions had already sent shockwaves to Southern Public Utilities. Streetcar workers comprised only one segment of James B.

\footnotetext{
${ }^{96}$ Spartanburg Herald, 18 July 1919, 1,5; Greenville Daily News, 18 July 1919, 1.

97 Journal and Carolina Spartan, 19 July 1919, 1.
} 
Duke's Piedmont workforce, which included electricians and mechanics. Yet, SPU's traction services also extended to Winston-Salem in North Carolina, as well as Greenville and Anderson in South Carolina. SPU president Zebulon Taylor took pre-emptive steps to forestall union encroachment into Duke's empire. On August 1, he gave substantial pay raises to all his streetcar employees, which served to divide their ranks in the coming strike. Jones had decisively won the first skirmish in South Carolina; now, battle lines formed in Charlotte, where Jones entered a much larger forum than Spartanburg. ${ }^{98}$

Spartanburg hosted the annual South Carolina labor conference on September 15. Given the state labor federation's relatively successful negotiations that July, its Secretary-Treasurer, John L. Davis, invited no less than Samuel L. Gompers himself. Governor Robert Cooper also planned to attend this significant labor meeting, in recognition of his largely unsung efforts to resolve Spartanburg's transit crisis. ${ }^{99}$

John L. Davis presided over South Carolina's Federation of Labor meeting, hailed by the Columbia Labor Advocate as "the most successful ever." Governor Robert Cooper gave an address touching on the Spartanburg strike and the importance of arbitration. South Carolina's labor contingent boldly endorsed the Plumb Plan as a solution to railroad receivership. Union leaders more cautiously addressed "Negro unions," favoring a Jim Crow approach, wherein blacks should be represented by their own State Federation and local chapters. The few black unionists present at the meeting quickly stressed to their white counterparts that they "sought emulation only in an industrial sense." This statement is especially relevant in light of concurrent events.

\footnotetext{
${ }^{98}$ Journal and Carolina Spartan, 11 August 1919, 1; Greenville Daily News, 13 August 1919, 11.

99 Journal and Carolina Spartan, 15 August 1919, 1; Labor Advocate of Columbia, 1 August 1919, 1.
} 
Only that previous August, the Southern Labor Congress convened in Asheville, North Carolina, where SLC President Jerome Jones from Atlanta made a surprise endorsement of black laborers as equals to whites in terms of union representation. ${ }^{100}$

More importantly, the Spartanburg streetcar strike occurred at the high watermark of labor activity in the Tri-City region. Both Anderson and Greenville played roles in the Charlotte regional strike, despite eventual defeat for the movement. Moreover, Spartanburg itself had changed since the war began. Unions had indeed established a solid foothold. By early 1920, Spartanburg's Central Labor Union had grown to include almost 20 chapters, jointly operating a co-op grocery store on South Liberty Street with $\$ 10,000$ capital. Union and non-union customers were treated equally in terms of prices, with business supervised by a nine-man board elected by the Central Labor Union. ${ }^{101}$ In retrospect, the Spartanburg streetcar strike seems relatively modest in its local impact. But it serves as a prelude to further strife across the Carolina Piedmont. Moreover, it encapsulates the major issues found in many Southern streetcar strikes throughout the time period. The company's refusal to negotiate with the international union triggers a strike for better wages and treatment. Inevitably, the city (or state) government is drawn into the debate, as local opinions clash over the presence of "outside" agitators. Violent incidents flare up over the use of scabs or strikebreakers. Finally, some concessions are made to the workers, but the company is not legally bound to recognize the Amalgamated Association, or even to permanently keep its agreements.

${ }^{100}$ Unfortunately, it seems Samuel Gompers declined John Davis's invitation to Spartanburg. John L. Davis should not be confused with the unsuccessful 1924 Democratic Presidential candidate from West Virginia. (Labor Advocate of Columbia, 1 August 1919, 1; 22 August 1919, 1; 19 September 1919, 1)

${ }^{101}$ Columbia Trade Review, 26 March 1920, 1. 
Regrettably, this proved the case with Spartanburg, whose fledgling union would suffer reversals in 1920, in light of the next chapter focusing on Charlotte's strike. 


\section{Chapter Six: Battle of the Barn}

Charlotte's rapid transition to a regional metropolis, initialized by the New South's textile revolution, accelerated when federal negotiators agreed to establish Camp Greene just outside Charlotte in July 1917. None other than Zebulon V. Taylor led the city's lobby effort, favorably impressing General Leonard Wood with the Piedmont's untapped potential. Southern Power held an outdoor banquet where General Wood intemperately criticized the Wilson Administration for its perceived lack of preparedness. Politics aside, Taylor's interests were well served by Camp Greene's construction, as Charlotte's street railway system expanded, permitting thousands of officers and enlisted men to socialize. Camp Greene officially disbanded in July of $1919 .{ }^{1}$

At this crucial time, Southern Power and Southern Public Utilities also strove to contain the labor movement in the Piedmont. To forestall a repetition of Spartanburg, Zebulon Taylor increased company wages by ten percent for motormen and conductors, beginning August 1, 1919. Prior to this announcement, SPU streetcar workers brought home 28 to 35 cents hourly, depending upon seniority. Taylor's platform men now earned 37 to 42 cents per hour, with annual raises of a single penny. Ostensibly, Taylor anticipated economic improvement through one-man safety cars, which would eliminate the number of workers on the lines. But Taylor's ten-percent wage increase also matched union rates won by Albert E. Jones in Spartanburg earlier that July. ${ }^{2}$

\footnotetext{
${ }^{1}$ Miriam G. Mitchell and Edward S. Perzel, The Echo of the Bugle Call: Charlotte's Role in World War I (Charlotte: Heritage Printers, Inc., 1979), 2-7.

2 Greenville Daily News, 3 August 1919, 1; 7 August 1919, 1; 11 August 1919, 1; Southern Public Utilities Magazine, Vol. 5, No. 1 (August 1919), 28.
} 
Despite Taylor's efforts, labor unrest soon began chipping away at Southern Power's powerful foundations. On August 4, 600 Columbia shop-men struck en masse for higher wages, leaving Southern Railways, Southern \& Atlantic Coastline, and Seaboard Air Line without skilled mechanics. The latter two railroads were still under federal management, so President Wilson expressed his outrage toward unauthorized "wildcat" strikes. Both union and government leaders expressed their fears that this independent strike might soon spread. No doubt, Zebulon Taylor likewise watched these new developments, given their scope and proximity to Southern Public Utilities' sphere. ${ }^{3}$

Taylor's concerns were soon confirmed on August 6, when forty Piedmont \& Northern platform men struck in sympathy with the Columbia shopmen and a related Southern Railways strike at Spencer, North Carolina. Since the electric Piedmont \& Northern belonged to Southern Power, this directly affected the Duke conglomeration. ${ }^{4}$

Despite Taylor's August wage increase, AASERE organizers sought to press their point in Charlotte, nerve center for the most powerful streetcar employer in the Carolina Piedmont. By this point, Southern Public Utilities had also acquired streetcar assets for Salisbury-Spencer, North Carolina. Albert E. Jones did not sit idly after his initial success in Spartanburg. Even while that Upcountry town resolved its streetcar conflict, Charles W. O'Daniel of the AFL had already organized AASERE Division 901, while A.E. Jones organized Division 904 in Greenville-Anderson. These two chapters were chartered in July 1919, along with Division 893 in Winston-Salem. ${ }^{5}$

${ }^{3}$ Labor Advocate of Columbia, Vol. 1, No. 2 (8 August 1919), 1.

${ }^{4}$ Greenville Daily News, 6 August 1919, 12.

${ }^{5}$ Motorman and Conductor, August 1919, 3; Walter Turner, "Development of Streetcar Systems in North Carolina," available from www.cmhpf.org, Internet, accessed 24 August 2006. 
Therefore, the Charlotte strike could not have come as a great surprise to "Buck" Duke and his lieutenants. But the question remains: how much personal involvement was there from Duke himself? While no correspondence remains between Duke and Taylor, one may safely assume the Southern Public Utilities president had his partner's complete confidence in handling potential streetcar strikes. Yet, John W. Bridwell, the federal conciliator sent to Charlotte in August, still predicted "Southern Power... may become involved, although not now shown on the surface." Bridwell also identified "the close affiliation of the Utilities [Company] and the Southern Power [Company]" as the central issue during the Charlotte Strike. Emphasizing Southern Power's ownership of 225 cotton mills and 2,000 miles of primary electrical lines, Bridwell urged his Washington superior, H.L. Kerwin to "just think of the magnitude of this company!" 6 By 1919, magnitude had indeed become a chief hallmark of the Southern Public Utilities Company. Long the nerve center for Duke's urban transportation, Charlotte's streetcar system now boasted fifty operating cars on almost 30 track miles, with about 7.8 million passengers. Bought by Duke in 1913, Winston-Salem's streetcars numbered 49 cars on about 10 busy track miles, with 4.1 million riders by 1920 . Gastonia's numerous mills received their public transportation service from the Duke-owned Piedmont \& Northern inter-urban electric railroad, connecting it to Greenville, Spartanburg \& Anderson Railway - also the possession of Southern Power. Moreover, Piedmont \& Northern had built a three-mile extension to Belmont Mills in March 1916. ${ }^{7}$

\footnotetext{
${ }^{6}$ National Archives and Records Administration, Department of Labor, Division of Mediation and Conciliation, Box 11, John W. Bridwell to H.L. Kerwin (20 August 1919)..

${ }^{7}$ Turner, www.cmhpf.org; Coleman and Humphreys.
} 
Charlotte's regional strike officially began on Sunday, August 10, 1919. The day before, Taylor met with his workers at the Mecklenburg Chamber of Commerce to discuss terms for a union contract. Albert Jones excused himself from these proceedings, hoping his absence would improve the meeting's tone. Representatives from all three local divisions agreed to a nine-hour workday, guaranteed overtime, and salaries from 41 to 45 cents per hour. SPU streetcar workers currently received no overtime for their 12hour shifts. Company officials indicated their income could not support union-dictated wage figures. Moreover, Taylor refused to negotiate with these three AASERE representatives, labeling their parent organization as a "foreign influence." Taylor conceded that he might negotiate with members from a local union, calculating that their bargaining strength would be weaker. ${ }^{8}$

Taylor reiterated his official position through the auspices of local newspapers, but saved his choicest words for Southern Public Utilities Magazine, where his words could be printed in full. Once again, the utility company would "deal or enter into a contract with unions of its own men," but refused to deal with outsiders. Taylor singled out the Amalgamated Association for its reputed "disorder, rioting, and bloodshed," citing the isolated violence in Spartanburg's recent strike, as well as a major walk-out in Brooklyn, New York." Entering into contract with the AASERE, Taylor argued, would "plant the seeds for trouble... for our Company and for the public which we serve." $\mathrm{He}$ specifically charged that the union's mandated wages might eventually force his company to raise fares, thereby reducing Charlotte's considerable number of riders. ${ }^{9}$

\footnotetext{
${ }^{8}$ Greenville Daily News, 9 August 1919, 1, 5; Charlotte Observer, 13 August 1919; Charlotte Observer, 15 August 1919, 9.

${ }^{9}$ Southern Public Utilities Magazine, Vol. 5, No. 3 (15 August 1919), 1-3.
} 
Initially, the company president took a paternal tone. Taylor professed respect for North Carolina Governor Bickett's "Square Deal” approach toward labor and capital. Taylor also stressed a lack of "ill feeling" toward his striking workers, expressing "personal regret" if he were forced to secure replacement workers to fill vacant positions. However, Taylor reminded his workers that they had "a very distinct duty and responsibility to the public." To demonstrate his own public spirit, Taylor assured Charlotte's citizens, wary of rioting and bloodshed: "We shall not import strikebreakers." Instead, Taylor proposed keeping his streetcars in barns until he could interview "good men of our own section and community," who would be paid at the company's best possible wage scale. Meanwhile, Taylor still hoped for a peaceful settlement with his striking employees, whom he often referred to as "our boys."

Following their rebuff, Taylor's "boys" convened at the Woodmen's Hall in Charlotte. At 11 p.m., on Saturday, August 9, Divisions 893, 901, and 904 elected to strike effective Sunday, August 10. Charlotte's Central Labor Union, with sixteen craft organizations and three thousand members, lent their support to the streetcar divisions. Jones felt commencing the strike on a Sunday would cause "a minimum of annoyance." Perhaps, Jones also anticipated potential support from the religious community, as most streetcar workers attended church. Presbyterians largely dominated Charlotte's society, but other Protestants were no less active, especially in the wards of downtown Charlotte. One prominent Methodist, attorney Marvin Lee Ritch, supported textile workers. ${ }^{11}$

\footnotetext{
${ }^{10}$ Southern Public Utilities Magazine, Vol. 5, No. 3 (15 August 1919), 1-3; Greenville Daily News, 11 August 1919, 1, 4, 7-8; 26 August 1919, 18.

11 Greenville Daily News, 12 August 1919, 2; Charlotte Observer, 10 August 1919, 3; Ann Ritch Brantley, interview by author, transcript, 19 September 2008.
} 
Meeting with city reporters, Albert Jones asserted that SPU motormen and conductors were 100 percent organized, totaling over 200 union members. Charlotte counted 120 members, while Winston-Salem had 65. Greenville-Anderson, South Carolina counted the remaining 30. However, during the arbitration process, Federal conciliator John Bridwell later counted the total number of Southern Public Utility men as follows: Charlotte (131), Winston-Salem (73), and Greenville-Anderson, (59). While approximately ninety percent of Charlotte and Winston-Salem streetcar workers were unionized, the same could not be said of Greenville-Anderson. Bridwell's precise figures suggest a degree of numerical overstatement on Jones's part. ${ }^{12}$

Albert E. Jones's leadership throughout the Charlotte strike deserves scrutiny. While he demonstrated courage and sincerity toward the region's workers, Jones also downplayed their precarious position in his reports to William D. Mahon. His confrontational personality clearly did not suit the region's conservative political climate. Moreover, Jones overestimated the strength of AASERE's support base in the Carolina Piedmont. For one matter, the streetcar union's three divisions lacked a labor network. While Columbia, South Carolina, and Asheville, North Carolina, had streetcar unions, these cities were too distant to afford much support to Charlotte. Southern Power electricians, organized that same year by D.L. Goble, were reliable allies, but they were fewer in number than the streetcar workers. ${ }^{13}$

When the Charlotte division staged its walkout on August 10, union president W.H. McFarlane united streetcar worker demands with those of forty Piedmont \&

\footnotetext{
${ }^{12}$ National Archives and Records Administration, Department of Labor, Division of Conciliation John W. Bridwell to H.L. Kerwin, 5 September 1919, , Box 111; Charlotte Observer, 13 August 1919; Charlotte Observer, 15 August 1919, 9.

${ }^{13}$ Motorman and Conductor, 11 September 1919, 78.
} 
Northern platform men already on strike. However, these railway men swiftly returned to work on August 11, after Southern Railways settled with its striking workers. Piedmont \& Northern workers remained on the job throughout the Charlotte regional streetcar strike, although at least one Southern Railways engineer took part in the events to come. ${ }^{14}$ Jones's hopes for worker solidarity suffered a further blow when Anderson SPU workers parted ways with their Greenville counterparts, showing up for work on Sunday, August 10. Citing their recent pay increase on August 1, Anderson streetcar employees issued a statement of loyalty to Southern Public Utilities. Under the heading, "A Study in Contrasts," Taylor exploited this development in Southern Public Utilities Magazine and regional newspapers. The company boasted that Anderson's platform men remained on the job "without a single deflection (sic)." Praising the Anderson workers, Taylor indicated their rebellious co-workers were not acting "of their own volition." Instead, the unionized workers were acting on the orders of "outside influences," who did not share their best interests. The company president also promised the Anderson SPU workers that their "splendid loyalty" would not be forgotten. ${ }^{15}$

How did this serious rift occur within the ranks of AASERE Division 904? Fear of unemployment or home loss may have convinced the Anderson contingent to remain on the job. One could point toward the respective labor experiences of Anderson and Greenville. Whereas Greenville's working class may have taken inspiration from the near-successes of 1914's Monaghan Mill strike, Anderson's 1916 strike ended with the traumatic eviction of mill workers by Palmetto National Guardsmen. Faith in their

14 Charlotte Observer, 10 August 1919, 3; Greenville Daily News, 11 August 1919, 1.

${ }^{15}$ Southern Public Utilities Magazine, Vol. 5, No. 3 (15 August 1919), 7-8; Greenville Daily News, 13 August 1919, 11. 
company's leadership may also have been a factor, as Zebulon Taylor's promised wage increases materialized in January 1920. Southern Public Utilities Magazine alleged their company's employees had "no thought of striking," while the Charlotte Observer confirmed Anderson's service was not suspended on August 10. ${ }^{16}$

Given Jones's inflated figures, Greenville-Anderson's union membership may have only accounted for about 30 of 59 total workers, with Anderson refusing to abide by August 9's decision to strike. One must also consider the possibility that Anderson's streetcar workers may not have actually agreed to join Division 904. Albert Jones included Anderson with Greenville's figures in order to exaggerate AASERE's presence in the region. Present-day Anderson and Greenville have developed alongside Spartanburg to create the Upcountry Tri-City region, but in August 1919, these three towns were still distinct entities, with different agendas. ${ }^{17}$

Immediately after the strike began, Greenville Daily News admonished local strikers for their "slight degree of ill-advised haste" even as the National Railway Conference sought to resolve their problems. The Greenville editorialist quipped that it was "better to strike 'on the job,' than to strike by quitting the job." ${ }^{18}$ However, other South Carolina Upcountry towns unaffected by the strike registered only cursory interest in Charlotte. While the Spartanburg Herald duly reported major developments in the Southern Public Utilities strikes, Charles Hearon's editorial column remained curiously

\footnotetext{
${ }^{16}$ Southern Public Utilities Magazine, Vol. 5, No. 3 (15 August 1919), 7-8; Charlotte Observer, 11 August 1919, 4.

${ }^{17}$ National Archives and Records Administration, U.S. Department of Labor, Division of Mediation and Conciliation, Box 111, John W. Bridwell to H.L. Kerwin (5 September 1919).

${ }^{18}$ Unfortunately, none of Anderson's surviving newspapers in the Caroliniana Library cover this time period, so one must assume Anderson's citizens relied on the Greenville Daily News. (Greenville Daily News, 9 August 1919, 4; 13 August 1919, 11).
} 
silent. Similarly, the Daily Spartan paid less attention to the Charlotte Strike, despite its editor's staunch conservative position. One might surmise both editors had felt enough had been said during the previous Spartanburg strike in July. ${ }^{19}$

In 1919, the Queen City had two major newspapers, the Charlotte Observer and the Charlotte News. One retired Charlotte News reporter, Emory Wister, reminisced that "back in the old days... the Observer was considered the conservative newspaper and the News was the liberal newspaper." Wister mused that when the "liberals got more liberal," many News reporters went over to the Observer. Both papers merged in the 1980s, with the Charlotte Observer remaining moderately liberal in its sympathy. Later in the century, the Observer led historical preservation efforts, while its editorials largely supported the return of Charlotte's trolley in the 1980s. ${ }^{20}$

Initially, the Charlotte News took a somewhat balanced position toward the union's strike. Emphasizing the moderating efforts of James Pardee during the ongoing Federal Commission on Electric Railways, Charlotte News editors Julian Miller and Jasper C. Hutto urged moderation. One representative News editorial, reprinted in Southern Public Utilities, even acknowledged "badly demoralized service" in

${ }^{19}$ Spartanburg Herald, 11 August 1919, 1; 12 August 1919, 1; 24 August 1919, 1, 5; 27 August 1919, 1, 5; Journal and Carolina Spartan, 11 August 1919, 1, 10; 16 August 1919, 1, 8; 25 August 1919, 1, 8; 28 August 1919, 1, 8.

${ }^{20}$ Charlotte Labor Herald also circulated during the strike, but sadly this newspaper is lost. Some fragmentary articles were quoted by other newspapers, but no microfilm exists in the Charlotte Library archives. (Emory Wister, interview by Edward Perzel, 23 May 1979, transcript, Special Collections, J. Murrey Atkins Library, University of North Carolina at Charlotte; Richard Maschal, "Forgotten Night of Fear," Charlotte Observer, 23 August 1994, 1E-2E). 
Spartanburg and Columbia. Since both South Carolina trolley lines were under AASERE contracts in 1919, this concession cost Southern Power very little. ${ }^{21}$

However, such conciliation did not inform the Charlotte Observer's ultraconservative editor, Colonel Wade Harris. Harris, a long-time foe of unionism, began circulating full-page propaganda inserts for the Sunday edition. These cartoonish drawings were unique to the Observer. Touted as "one of a series," at least twenty different articles were circulated between July and August. One such item invoked the images of George Washington, Thomas Jefferson, and Abraham Lincoln, showing their disapproval toward "un-American" labor organizers. "Tousle-haired radicals" had misled good American workers to wreck the sacred free enterprise system. Union organizers were also demonized in the Observer as Semitic stereotypes with disheveled appearances. Those who listened to these "Apostles of Unrest" were portrayed with sloppy clothes and slouching postures, while virtuous Americans walked past the rabble-rouser, wearing stylish garments and hats denoting respectability and affluence. ${ }^{22}$

What effect did Wade Harris's virulent propaganda have on Charlotte's public opinion? None of the letters printed in the Charlotte Observer throughout the strike endorsed the cause of unionism. Furthermore, two representatives from the Charlotte Central Labor Union petitioned U.S. Senator Lee S. Overman, a staunch Democrat, citing Colonel Wade Harris's “tremendous advertising campaign... to prejudice the citizens." Charlotte's Central Labor Union implicated Zebulon V. Taylor's inflammatory statements in the regional newspapers as another factor in swaying people against

${ }^{21}$ Southern Public Utilities Magazine, Vol. 5, No. 3 (15 August 1919), 9-15; Charlotte Observer, 16 July 1919, 1; 10 August 1919, 3.

${ }^{22}$ Charlotte Observer, 20 July 1919, 11; 15 August 1919, 11; 
organized labor. Federal conciliator John W. Bridwell later sent samples of Taylor's screed and Harris's anti-labor cartoons to Washington for "future use.",23

Attorney John Franklin (Jake) Newell (1869-1945) also excoriated the Observer for failing to present the "bold and unbiased" truth to its readers. Newell, a liberal Republican, had recently won acquittal for a black jitney driver accused of murdering a white soldier outside Camp Greene. Newell ably demonstrated how his client had been nearly robbed at gunpoint. Newell later represented the Charlotte Central Labor Union in the strike. In his post-strike letter to North Carolina Governor Bickett, Newell expressed his professional opinion that the streetcar workers' cause had been "muddled in Charlotte by a wave of propaganda," exercising "an unhealthy control of public sentiment." ${ }^{24}$

Some citizens were certainly swayed by Wade Harris, but others were neutral or even sympathetic. Loy Cloninger maintained that Charlotte's riding public did not express much anger toward the SPU streetcarmen during or after the strike. In fact, Cloninger indicated strong vocal support from North Charlotte, where hundreds of textile workers traveled by streetcar to Atherton Mill. While strikebreakers manned the cars in late August, ordinary people with "Model T's" would sport "eight or nine hanging... on [the] old running boards." These jitney drivers were allowed by the city to charge a dime per passenger, keeping the proceeds for themselves. Historian Carol Shaw's urban

${ }^{23}$ National Archives and Records Administration, U.S. Department of Labor, Division of Mediation and Conciliation, Box 111, John W. Bridwell to H.L. Kerwin, (20 August 1919), Charlotte Central Labor Union to Lee S. Overman, (25 August 1919); Carol Shaw, "A City in Conflict: the 1919 Charlotte Streetcar Strike" (unpublished honors thesis, University of North Carolina at Chapel Hill, 1980), 41-42; Loy C. Cloninger, interview by Allen Tullos, 18 June 1980, transcript, University of North Carolina at Chapel Hill, Southern Historical Collection, Louis Round Wilson Library, 14-15.

${ }^{24}$ National Archives and Records Administration, U.S. Department of Labor, Division of Mediation and Conciliation, Box 111, Jake F. Newell to Governor Thomas W. Bickett (3 September 1919); Star of Zion, 8 May 1919, 6. 
research confirms a proposed local ordinance permitting jitneys during the strike, which would suggest that some elements of the Charlotte city government were tolerant enough toward the striking streetcar workers to refrain from halting a jitney boycott. ${ }^{25}$

To John Paul Lucas's credit, Southern Public Utilities Magazine initially refrained from excessive abuse when the strike began. However, after the events of August 25 and 26, Lucas employed Red Scare tactics to further damage the union's flagging support base in the Piedmont. Much of Southern Public's cant quoted directly from Scripture, while other examples came from major newspapers. "A Strike for Power," in the New York Commercial, cast the labor war as "Americanism versus Russianism.” Another chief contributor, F.G.R. Gordon of the American Anti-Socialist League, preached about the worldwide menace of Socialism, using selective examples from history. Lucas also delighted in teaching a "Lesson for the Radical," quoting Massachusetts governor Calvin Coolidge, hero of the thwarted Boston Police Strike. ${ }^{26}$

Ultimately, how persuasive were these anti-labor cartoons from the Charlotte Observer? One can assume that Harris's propaganda merely reinforced already-existing prejudices toward labor organizations, especially among many middle-class and elite Charlotte citizens. Others who empathized with the plights of workers were either offended, as in the case of the Charlotte Central Labor Union, or otherwise ignored the newspapers outright. Nevertheless, the violence ensuing in late August 1919 eclipsed any incident in the Queen City's recent history. Some quantity of hate must have been exacerbated by the city newspapers' irresponsibility. Wartime passions had not yet

\footnotetext{
${ }^{25}$ Cloninger, 14-15; Shaw, 16.

${ }^{26}$ Southern Public Utilities Magazine, Vol. 5, No. 5 (October 1919), 1, 5-10, 15; Vol. 5, No. 6 (November 1919), 13; Vol. 5, No. 7 (December 1919), 1.
} 
abated, local prejudices toward foreigners permeated each level of society, and new fears of Bolshevism coursed through the media. One can further speculate about the ramifications if these virulent drawings had been circulated in Greenville or WinstonSalem. Fortunately, Colonel Wade Harris lacked the influence of a Pulitzer or a Hearst. Meanwhile, the Charlotte regional strike continued unabated in its first week. Greenville's public transportation remained paralyzed, while cars in Anderson ran smoothly. Greenville Daily News supported municipal ownership of transportation, based on the city's ownership of its waterworks. However, despite the Upcountry paper's unusual championship of "complete democratization of transportation," Zebulon Taylor still purchased advertising space in order to publish his statements and solicit strikebreakers. Greenville's newspaper also promulgated a rumor that union motormen were allegedly paid 60 cents per hour in comparison to a college professor's 18 cents. Another columnist made light of the entire situation, stating simply: "The Walking is Good." This editorial further reasoned that Greenville did not rely on streetcar transportation as much as Spartanburg, although the writer conceded the area's farm and textile laborers would soon feel the strike's effects. ${ }^{27}$

Charlotte newspapers did not comment on the first three days of the strike, although they covered the union's activities. Initially, the strike appeared orderly. Workers continued to appeal to their former employers for union recognition, with predictable, if courteous refusals. Department of Labor officials evidently deemed the situation too minor to consider intervention. The Amalgamated Association's first appeals to the U.S. Department of Labor were postmarked August 18. At the time,

${ }^{27}$ Greenville Daily News, 11 August 1919, 4; 12 August 1919, 4; 13 August, 1; Charlotte Observer, 11 August 1919, 4. 
Washington's policy-makers felt that streetcar strikes should be resolved at the local and state levels. In this spirit of cooperation, Charlotte's progressive mayor, Frank Ramsey McNinch, promised to help seek a mutually beneficial solution. Preliminary mediation took place in the Mecklenburg County Chamber of Commerce. ${ }^{28}$

Rescinding Charlotte's antiquated town alderman board, city officials established the new Chamber of Commerce on June 17, 1915. Charlotte's first Board of Directors included conservative businessmen, such as William States Lee, Zebulon Vance Taylor, and Edward Dilworth Latta. Yet other members were confirmed liberals, such as W.S. Alexander and Clarence “Booster” Kuester. In 1912, Alexander had developed Washington Heights to accommodate the growing African-American population in Biddleville. "Booster" Kuester started out as a travelling salesman and druggist before entering city politics. Well-liked for his optimistic, sunny disposition, Kuester received his nickname due to his promotional efforts on behalf of Charlotte. Both Kuester and Alexander played significant roles on the arbitration commission chaired by the mayor. ${ }^{29}$

Meanwhile, the forces of labor gathered under Albert E. Jones and D. L. Goble, leader of the electricians union. Strikers staged a midnight demonstration between August12 and 13, at the Southern Public Utilities substation on present-day Elizabeth Street. At approximately 3 a.m., two unionized electricians, J.L. Baker and S. M. Farris,

${ }^{28}$ Charlotte Observer, 11 August 1919, 4; Raleigh News and Observer, 11 August 1919, 1; Greenville Daily News, 11 August 1919, 4; National Archives and Records Administration, U.S. Department of Labor, Division of Mediation and Conciliation, , Box 111, William B. Fitzgerald to Hugh Kerwin, telegram, 18 August 1919; Hugh Kerwin to John W. Bridwell, telegram, 18 August, 1919; Shaw, 16-17.

${ }^{29}$ Norman J. Pease, interview by Edward Perzel, 22 May 1979, transcript, Special Collections, J. Murrey Atkins Library, University of North Carolina at Charlotte; LeGette Blythe and Charles R. Brockmann. Hornet's Nest: the Story of Charlotte and Mecklenburg County (Charlotte: McNally of Charlotte, 1967), 341. 
cut municipal power for an entire hour. Charlotte Police Chief Walter B. Orr quickly regained control of the substation. Baker faced criminal trespass charges and paid an undisclosed fine, while Farris escaped charges altogether, in exchange for giving testimony to the police and Southern Public Utilities. Farris implicated an alleged conspiracy fomented by the AASERE, referred to simply as "the Association." 30

However, no conspiracy motivated the three hundred or so North Charlotte textile workers who descended upon Elizabeth Street later that night on August 13. In general, streetcar union members initially welcomed the mill-hands, but they also sought to discourage undisciplined crowds from taking part in their demonstrations. But SPU conductor Jesse B. Ashe saw these mill hands as a potentially dangerous crowd, often engaging in fisticuffs and drunken brawls. Ashe later described North Charlotte as "a bad place," characterized by "cutting and fighting on the weekends." Ashe also believed these "mill people" used the streetcar strike for their own purposes. Loy Cloninger confirmed that most of the strike sympathizers came from the textile mills ringing Charlotte. North Charlotte textile workers may also have felt a particular animosity toward Chief Walter B. Orr, who had a controversial reputation among Charlotte's working class. However, this first assembly of picketers dispersed without incident. ${ }^{31}$

Zebulon V. Taylor exploited these minor acts of civil disobedience to their fullest potential. Using the company magazine and local newspapers, Taylor took to the offensive. Exaggerating the actual impact of the Elizabeth Street incidents, Taylor asserted: "We are standing between you and lawlessness." The corporate executive

\footnotetext{
${ }^{30}$ Charlotte Observer, 13 August 1919, 3; 20 August 1919, 2; Shaw, 17-19.

${ }^{31}$ Charlotte News, 14 August 1919, 1; Shaw, 18-19; Ashe interview; Cloninger interview.
} 
vowed to fight "vicious outside influences" responsible for "jeopardizing the lives of the suffering in hospitals." 32 Condemning Albert Jones's "Organization" in tenebrous terms, Taylor questioned the real motive behind the strike, claiming that his company offered higher wages than those contracts Jones had won for Spartanburg. He accused the AASERE of duping J.L. Baker and S.M. Ferris on the previous night, then abandoning them to the courts. ${ }^{33}$

Taylor wrote a simultaneous appeal to his crewmen to return under their original contracts. "I have thought...with all the sympathy one human being might have for the distress of another," the executive reassured. The president blamed "foreign influences" for "prying apart the close bonds" between his company and its professed "friends." 34 Comparing these labor leaders to German soldiers, bent on "victimizing" innocent "Southern" women and children, Zebulon Taylor openly declared war on the strikers. Southern Public Utilities began placing newspaper advertisements for replacement motormen on August 15. R.L. Wommack took charge of the interview process, which continued for ten days. $^{35}$

Mayor Frank R. McNinch (1873-1950) subsequently abandoned his neutrality, publicly denouncing the perceived "outrage against an innocent and helpless public." Charlotte could never "countenance" such a "high-handed invasion" of private property, although he did not specify whether he meant the rebellious electricians or the protestors. McNinch also declared further challenges to public safety would incur "personal risk."

${ }^{32}$ Charlotte News, 14 August 1919, 1; Greenville Daily News, 11 August 1919, 4.

${ }^{33}$ Charlotte Observer, 14 August, 1919, 5; Greenville Daily News, 12 August 1919, 8; 15 August 1919, 12.

${ }^{34}$ Charlotte Observer, 17 August 1919, 1-3.

${ }^{35}$ Charlotte Observer, 16 August 1919, 5; Greenville Daily News, 18 August 1919, 4. 
However, behind the scenes, McNinch exercised his municipal office to seek a compromise between the utility company and representatives of the AASERE. ${ }^{36}$

Frank Ramsey McNinch came from staunch Presbyterian stock, a curious mixture of parochial and progressive traits. Historian Janette Greenwood characterizes McNinch as a "middle-class reformer" who began as a traveling salesman. A notable Prohibitionist, McNinch drank goat's milk for his ulcers. After graduating from law school, McNinch entered local politics as a Democrat. In 1917, McNinch succeeded his older brother, Samuel S. McNinch, as Charlotte Mayor. In this office, the younger McNinch distinguished himself as a "soft-spoken" problem-solver whose political instincts made many friends and foes alike. According to his nephew, Samuel S. McNinch III, his uncle "did not give a damn; he was fiercely independent." ${ }^{37}$

During the week of August 15, Mayor McNinch presided over talks between strike leaders and SPU president Zebulon Taylor. Their primary arguments focused on company wages. Taylor claimed corporate revenues could not support the Amalgamated's proposed wage increase of three pennies. Given the SPU executive's affluent lifestyle, his justification must have infuriated the union. His wife, Irving Scales Taylor, had recently sold their opulent mansion in Myers Park to their business partner, James B. Duke himself. ${ }^{38}$ Now aware of Taylor's campaign to replace his colleagues, local streetcar union president W.H. McFarlane rejected Taylor's explanation. Mayor McNinch congratulated McFarlane for his "orderly manner" throughout the meeting.

${ }^{36}$ Charlotte Observer, 13 August, 1919, 5.

37 Samuel S. McNinch III, interview by author, 18 September 2008, transcript; Janette T. Greenwood, The Black and White Better Classes in Charlotte (University of North Carolina Press: Chapel Hill \& London, 1994), 129.

${ }^{38}$ Charlotte Observer, 17 August 1919, 1-3; Hanchett 178-9. 
Albert E. Jones withdrew from the proceedings as a gesture toward local politics, but inwardly, the union organizer must have seethed at his harsh treatment in the city newspapers. $^{39}$

Throughout the conflict, Charlotte Observer editor Wade Harris remained highly biased against labor. Harris expressed "no sympathy with [the strikers'] attempt to hold up [community services] because of a mere quarrel as to [with] whom the employers will deal." The Charlotte News subsequently began to shift from cautious tolerance to outright dislike toward Albert Jones, questioning: "Why the services of the professional?" Julian Miller further queried whether the Charlotte streetcar workers should "wed themselves to this professional organizer instead of shouldering the responsibility themselves?" Likewise, the Greenville Daily News grew impatient with the ongoing strike. "At the outset," pronounced the editor, "public opinion favored the employes (sic)." However, the workers" "use of outside interference" delayed a negotiation with President Taylor. The Greenville Daily News expressed resentment toward such outsiders for "failing to recognize the South's ability to solve its own crises.",40

Meanwhile, Zebulon Taylor kept publishing calculated insults against the streetcar union in regional newspapers. Taylor seldom referred to the streetcar union or Jones by name, instead using euphemisms like "Foreign Organized Autocracy," or "Professional Foreign Agitator." Taylor also compared the AASERE to the Imperial German Army, claiming the streetcar union employed similar brutality to assert control over the city of Charlotte. For Jones, who fought for industrial democracy as he

39 Charlotte Observer, 17 August 1919, 1-3.

${ }^{40}$ Charlotte Observer, 15 August, 1919, 5; Charlotte News, 12 August 1919, 10. 
understood it, such words questioned his organization's integrity, not to mention his own patriotism. Unfortunately, Jones's temper got the better of his judgment. ${ }^{41}$

On August 17, Albert E. Jones delivered a vitriolic speech in the Mecklenburg Courthouse. Reporters listened intently as Jones addressed the entire Chamber of Commerce on behalf of his organization. Without naming James B. Duke or Southern Power, Jones openly accused the "capitalists who employ Mr. Taylor" of controlling Charlotte's local government, newspapers, and banks. Jones further upbraided Southern Public Utilities for gouging its customers at ten cents per kilowatt, while refusing to pay their workers a living wage. Lastly, Jones attacked Zebulon Taylor's paternalistic overtures as the "greatest piece of camouflage ever written," while his propaganda served as an "insult to the intelligence of every man." 42

Jones's outburst immediately met with venomous bites from the local press. Charlotte Observer assistant editor William B. Sullivan challenged Jones to substantiate his charges toward the newspapers. Sullivan called his statement "the most pronounced instance of public incitation to the passions of man that has ever been promulgated in Charlotte." In the Charlotte News, Zebulon Taylor labeled Jones a "rank slanderer," appealing to the loyalty of "Anglo-Saxon" and "Scotch-Irish" citizens to reject his "filthy falsehoods." Taylor concluded his sermon on nativism with an imperative to his wayward "boys": "Away with him!" 43 Even more injurious to the streetcar unions, Jones's tirade alienated Frank R. McNinch, the one man who might have helped his cause. The mayor decried Jones' accusation as a "willful and scurrilous lie." On August

\footnotetext{
${ }^{41}$ Greenville Daily News, 12 August 1919, 8; 18 August 1919, 18.

${ }^{42}$ Charlotte Observer, 17 August 1919, 11; Greenville Daily News, 18 August 1919, 18.

${ }^{43}$ Charlotte Observer, 23 August 1919, 2; Morrill, 17.
} 
22, Albert Jones subsequently retracted his words in a contrite letter to Mayor McNinch, but the Ohio labor organizer would be excluded from future negotiations. Division 901 president W.A. McFarlane, however, remained in good standing. ${ }^{44}$

Jones's public statement, if tactless in its accusations, certainly bore many elements of truth. Did not Zebulon V. Taylor belong to the Charlotte Chamber of Commerce? And was Taylor not a close advisor and partner to James B. Duke, one of the pre-eminent capitalists in the region? Conciliator John W. Bridwell said much the same of Southern Power's influence throughout the region, but he confined these criticisms to his superiors in Washington. Jones cut ties he could not afford to severbecause Mayor McNinch's disapproval now stripped the beleaguered streetcar workers of their chief and most effective advocate. Fortunately, a new leader arose to unite the Charlotte workingmen in the mounting struggle.

Charlotte attorney Marvin Lee Ritch (1889-1971) had little benefit to gain from supporting the cause of organized labor. However, Ritch's Scotch-Irish Methodist family shared agrarian roots with many resettled farmers who now staffed the Piedmont's textile mills. Ritch escaped factory drudgery through his prowess on high school and college basketball courts. Leaving Chapel Hill at age twenty-one, Ritch transferred to Georgetown in 1910, where he captained their first varsity program. Playing both forward and center during the 1912-13 seasons, Ritch achieved records that still stand almost a century later. Ritch would remain active in high school and college athletics throughout his public career, coaching basketball and football. ${ }^{45}$

\footnotetext{
${ }^{44}$ Albert E. Jones to Frank R. McNinch, letter, 22 August 1919, reprinted in Charlotte Observer, 23 August 1919, 2.

${ }^{45}$ http://www.alumni.unc.edu/learning/basketball.html, accessed 10 November 2003.
} 
Ritch also seems to have been something of a square peg. His surviving daughter, Ann R. Brantley, confesses Ritch was well-liked, but had little use for social graces. During his sojourn at Georgetown, he was the only Protestant on the varsity basketball team. Instead of finishing his program at Georgetown as a "tramp athlete," Ritch chose to clerk for several Washington law firms. Licensed to practice in North Carolina, Ritch moved to the burgeoning city of Charlotte. Shortly before World War I, Ritch married Hazeline Morris, a vivacious art teacher who soon gave birth to a daughter. During the war, Ritch served as city attorney and coached football at Chapel Hill. But as the nation celebrated the Armistice in November 1918, tragedy befell Hazel Ritch. Complications from influenza led to her untimely death from pneumonia at age 28. Marvin Ritch's promising legal career offered him the only positive means to work through his sorrow. Ritch's loss might also explain his energetic burst of pro-labor activity in 1919-20, leading streetcar and textile workers in a brief, yet impressive coalition. ${ }^{46}$

On August 18, Zebulon V. Taylor issued an ultimatum to his striking workers: return to work by 5 p.m. on the following day or face a lockout. Taylor's lockout order triggered a joint meeting of representatives from the Chamber of Commerce, the Charlotte Merchant Association, the Charlotte Automotive Association, and the local Rotary Club. Mayor McNinch's ad hoc Citizen's Committee subsequently exerted pressure on Taylor to retract the lockout. Taylor agreed to meet with union representatives, giving them his assurance that he would not discharge employees who belonged to the union. However, his proposed contract once more fell short of

\footnotetext{
${ }^{46}$ Marvin L. Ritch, registration card, Mecklenburg County Selective Service, 5 June 1917; Hazel M. Ritch, death certificate, November 25, 1918, North Carolina State Board of Health; Washington Post, 22 October 1918, 10; Ann Ritch Brantley, interview by author, transcript, 19 September 2008.
} 
expectations, because it lacked recognition of the AASERE. Workers resumed their strike amid growing public concerns; the strike now approached two weeks without hope of compromise. ${ }^{47}$

By this point, Albert Jones appears to have contacted William B. Fitzgerald at the AASERE's Detroit headquarters. Fitzgerald consequently appealed to Hugh Kerwin, chief conciliator of the U.S. Labor Department, to dispatch a Federal arbitrator to handle the Charlotte situation. John W. Bridwell arrived from Atlanta on August 20, reporting the chief problem as being one of union recognition. Bridwell quickly assessed Zebulon V. Taylor as the central figure, and urged his superior to personally wire the Southern Public Utilities executive, although no record exists of such a telegram. Bridwell also concluded that Albert Jones's rash statement against Taylor had aggravated the union's case in Charlotte. Bridwell instantly began coordinating his efforts with the Queen City's Central Labor Union, which repeatedly commended the Washington conciliator's quiet and earnest approach toward the streetcar strike. ${ }^{48}$

On August 19, attorney Marvin L. Ritch seized the proverbial gauntlet, speaking on the strike at Mecklenburg Courthouse before two thousand Charlotte citizens. Early in the strike, Ritch began mobilizing nearly 2,000 strike sympathizers among the region's mill towns. Some came from North Charlotte, but many more were poor textile workers from Gastonia and Albemarle. Gastonia's mill hands were accustomed to riding

${ }^{47}$ Charlotte News, 18 August 1919, 15; Charlotte Observer, 20 August 1919, 4; Greenville Daily News, 21 August 1919, 6; Shaw, 24-26.

${ }^{48}$ William B. Fitzgerald to Hugh Kerwin, telegram, 18 August 1919; H.L. Kerwin to W.B. Fitzgerald, telegram, 18 August 1919; H.L. Kerwin to J.W. Bridwell, telegram, 18 August 1919; Charlotte Central Labor Union to Hon. Lee S. Overman, 25 August 1919; Department of Labor, Division of Conciliation, National Archives and Records Administration, Box 111. 
subsidiary lines belonging to Piedmont \& Northern, but Ritch exhorted his friends to boycott these trolleys in support of the AASERE. ${ }^{49}$ Foreseeing Taylor's employment of armed strikebreakers, Ritch warned townspeople they would ride Piedmont \& Northern and Southern Public Utilities streetcars "at their own risk." Some conservatives decried Ritch's remark out of context, alleged a veiled threat on the attorney's part. However, Ritch defended his speech, indicating that the strikebreakers were a risk factor for trolley passengers owing to their violent nature and lack of work experience. ${ }^{50}$

Another brief period of uneasy quietude fell over Charlotte as the conciliation process continued for three days under J.W. Bridwell's capable direction. Possibly at Bridwell's request, Albert Jones formally apologized to the City Commissioners on August 22, hoping for a rapprochement with Mayor McNinch. However, the mayor barred Jones from further proceedings. Only one man, North Charlotte merchant W.H. Hall, spoke in Jones's defense, protesting that Charlotte's new form of government concentrated too much power in the hands of too few men. Meanwhile, electrician D.L. Goble formally took over the representation of AASERE Divisions 893, 901, and $904 .^{51}$

On August 23, Mayor McNinch and his Citizens' Committee proposed recognizing the three AASERE divisions without reservations, for a trial period of one year. Also present during the negotiations were Zebulon Taylor and his treasurer, E.C. Marshall. However, Taylor spurned the Committee Report, announcing limited streetcar service would resume on August 25 -- with strikebreakers manning the vehicles. In exasperation, John Bridwell wrote his supervisor, describing the company president's

\footnotetext{
${ }^{49}$ Charlotte Observer, 13 August, 1919, 3.

${ }^{50}$ Charlotte Observer, 20 August 1919, 4; 30 August 1919, 11.

${ }^{51}$ Charlotte Observer, 22 August, 1919, 5; Shaw, 28-29.
} 
obdurate refusal to accept even his "home people's" suggestion. He suspected Taylor's union-busting tactics had received direct support from Duke himself. However, despite obvious corporate connections, the conciliator also acknowledged each company had its own president. Still hoping to appeal to Taylor as a disinterested party, Bridwell resolved to reach a "peaceful solution" over the next week. ${ }^{52}$

Zebulon V. Taylor certainly had the capacity to make his own decisions. But Bridwell's hope for compromise was ill-placed. Taylor's response to the Citizens Committee said simply: "a thousand times no." Taylor argued for his company's "industrial freedom," and upbraided Mayor McNinch for harboring sympathy for a "Foreign Organization," founded upon "I.W.W.-ism and Bolshevism.” More significantly, Taylor withdrew his previous offer to reinstate his former employees. On Monday, 25 October, Taylor's strikebreakers readied for their first day. Picketers gathered at the Dilworth streetcar barn, where Police Chief Orr had stationed nearly forty patrolmen. One replacement crew fired several gunshots to disperse a crowd blocking the tracks, yet the police said nothing. Protecting Southern Public Utilities interests through intimidation and force, Taylor's replacements enjoyed tacit support from Charlotte's police chief, Walter Baxter Orr. ${ }^{53}$

Walter Orr (1883-1957) came from a family of police officers, beginning with his father, Assistant Police Chief Joseph L. Orr, a Confederate veteran who lost one arm fighting under Stonewall Jackson. Joseph Orr served as a police officer for forty-two

${ }^{52}$ National Archives and Records Administration, U.S. Department of Labor, Division of Mediation and Conciliation, Box 111, J.W. Bridwell to H.L. Kerwin (24 August 1919), Final Report of Commission (23 August 1919); Charlotte Observer, 24 August 1919, 2; Charlotte Observer, 25 August 1919, 4.

53 Charlotte Observer, 25 August 1919, 4; Charlotte Observer, 26 August 1919, 1-2. 
years. Father and son also shared a tradition of ringing the First Presbyterian Church bells for each New Year. Walter Orr rose swiftly through police ranks, serving as Deputy Sheriff of Mecklenburg County during the war years. On 14 May 1919, Walter Orr succeeded Police Chief Neal Elliot at age thirty-five. Hence, when the Charlotte strike ensued in August, Chief Orr had just assumed his new responsibilities. Orr also had a reputation for strong-arm tactics directed toward the working class in North Charlotte. Therefore, he likely saw Taylor's strikebreakers as a means to combat lawless elements. ${ }^{54}$ According to SPU conductor Loy Cloninger, local streetcar men came to view gun-toting Southern Public Utilities strikebreakers as "outsiders" who usurped the rightful jobs of Southerners. Following an unwritten code of the South, many working men may have believed that no true Southerner would deprive his neighbors of their livelihood. Strikebreakers allegedly pocketed daily income from their shifts, and outraged locals with violent behavior. Loy Cloninger recalled "some guy" offering to catapult a dynamite charge atop the paint shop building where the strikebreakers were quartered. Even though most of the strikebreakers were from Georgia and the Carolinas, Cloninger still believed these were Northern "scabs." John W. Bridwell confirmed this general perception toward strikebreakers as "foreigners" to his supervisors in Washington. ${ }^{55}$

At dusk, Taylor's men returned their cars to Dilworth, where two hundred outraged townsfolk greeted them with harangues and threats. These men were mostly rowdies from North Charlotte, according to several sources. Apparently, the only

\footnotetext{
${ }^{54}$ Donna Johnson, Descendants of James “Whistling” Orr, 2008, available from http://www.geocities.com/pawcreek.geo/orr/nti00120.htm; Internet; accessed 9 August 2009; Hanchett, 73-74.

${ }^{55}$ National Archives and Records Administration, U.S. Department of Labor, Division of Mediation and Conciliation, Box 111, John W. Bridwell to Hugh L. Kerwin (26 August 1919); Cloninger interview, 7.
} 
streetcar men present anywhere near the Dilworth barn were night foreman Loy

Cloninger and an inspector named Ramseur. They were permitted by their union leaders to remain on line because the replacement workers lacked qualified night supervisors. Jesse Ashe also did not believe there were any union members present, nor did he acknowledge "foreign" strikebreakers manning the cars. Ashe, at best a passive strike supporter, admitted several decades afterward that he had "lain low until matters were straightened out." 56

Mecklenburg Sheriff Newt W. Wallace made peaceful overtures to the hostile crowd, observing no weapons among the strikers. Nonetheless, several men tried to swarm over the rope barrier to lash out against the so-called "wops" and "scabs," now lodged in a nearby shop building. At approximately 10 p.m., Patrolman Thomas H. Merritt struck teenager Clem Wilson to the pavement, senseless. Merritt described Clem Wilson as having "pressed too closely." One unnamed strikebreaker later attested Wilson went for Merritt's holstered pistol. However, several other witnesses swore that Merritt had kicked Wilson's prone body, while two other officers held rescuers at bay with their sidearms. Loy Cloninger also witnessed a Charlotte police officer strike a young man named Wilson using his gun, but decades later, the retired foreman confused Clem with his older brother, John. Some spectators thought Clem dead, but Sheriff Wallace sent the unconscious sixteen-year-old boy over to St. Peter's Hospital. ${ }^{57}$

Sheriff Wallace and a St. Peter's nurse later testified Clem Wilson had been inebriated, which, if true, begs a question. Some eyewitnesses described many of these

\footnotetext{
${ }^{56}$ Cloninger interview, 1-9.

${ }^{57}$ Charlotte Observer, 26 August 1919, 1-4; 19 October 1919, 7; 17 November 1919, 9; 18 November, 10; Charlotte News, 25 August 1919, 1; Cloninger, 1-8.
} 
onlookers as being teenage boys in "shirtsleeves," perhaps returning from a baseball game. Hardly a Bolshevik, Clem may have passed through Dilworth to partake of illicit alcohol after a hot summer's evening. Despite the recent advent of Prohibition, several bars flourished in downtown Charlotte. Tavern-keeper Dick Wentz would later admit to selling "enough alcohol to fill a courthouse" during the last August weekend. ${ }^{58}$

Some demonstrators allegedly threatened to lynch Thomas Merritt, perceiving him as Clem Wilson's “killer.” However, Sheriff Wallace assured the boy's safety, convincing most of the crowd to disperse. By midnight, only fifty or so hotheads lingered to glare at Chief Orr's thirty-man barricade. Frank Boomershine, who resided across from the Dilworth car-barn, later became a police eyewitness. Boomershine's testimony later portrayed this small group of demonstrators as a lynch mob of two hundred. Boomershine, a Charlotte businessman, said he overheard this mob take a vote to kill Chief Orr as well as "the man who hit Wilson." Boomershine also testified that a gang proposed to overturn R.L. Wommack's private automobile parked in front of the car-barn. Boomershine later alleged their ringleader to have been Clem Wilson. ${ }^{59}$ But one must also consider that Boomershine's testimony emerged weeks after the strike, when Clem Wilson proffered murder charges against Chief Orr. Clem Wilson may have lacked good judgment, but he might just as well been a bystander caught up in a surge.

During this interval, John Wilson had learned of his sibling's injury from North Charlotte police. In his horse buggy, he arrived at Dilworth by 12:45 a.m., seeking his brother. The 1920 census manuscripts lists two John Wilsons in North Charlotte, both of

\footnotetext{
${ }^{58}$ Charlotte Observer, 26 August 1919, 3-4; 19 October 1919, 7; 17 November 1919, 9; 18 November, 10; Charlotte News, 26 August 1919, 1.

${ }^{59}$ Charlotte Observer, 26 August 1919, 3-4; 19 October 1919, 10; 17 November 1919, 9; 18 November, 10; Charlotte News, 26 August 1919, 1.
} 
whom were employed on farms. Chief Walter B. Orr later claimed John Wilson had a "bad reputation as fighting man." Loy Cloninger also described Wilson as a "rough kind of guy." According to Chief Orr, John Wilson reportedly approached the streetcar barn with "a crowd surging around him," demanding in "a boisterous tone" why his brother Clem had been struck. However, Sheriff Wallace described John Wilson's conversation with Chief Orr as "most friendly" in tone." Deputy Sheriff V.P. Fesperman confirmed Wilson shook his hand before speaking with Chief Orr. Orr absolved himself of Clem's injury, but picketers condemned the senior policeman for a liar. ${ }^{60}$

Loy Cloninger stood just before several streetcars positioned as barricades to the Dilworth car barn. Policemen had taken cover inside the streetcars, whose windows were lowered to permit firing. Cloninger half-jokingly described the strike sympathizers as forming their own "Hindenburg Line" across the street, meant to block outgoing streetcars. Picketers taunted and challenged the strikebreakers to send out a car to be vandalized - actions that the streetcar men would never have condoned. As a motorman, Loy Cloninger's perspective is perhaps the most unbiased, although one must allow for passage of time. When Cloninger reported his version of the events to a Southern Power claims agent, the company official promptly buried his account. ${ }^{61}$

Chief Orr, after speaking briefly to John Wilson, later claimed a swarm of rioters followed in Wilson's wake. "Get back, every damn one of you," Orr called out to the crowd before taking cover. Chief Orr's sidearm had already cleared his holster at this point. The next few moments remain perhaps the most mysterious in Charlotte history.

\footnotetext{
${ }^{60}$ Charlotte Observer, 5 September 1919, 1-2; 19 October 1919, 7; 18 November 1919, 9; 20 November 1919, 4; U.S. Bureau of the Census, 1920, Mecklenburg County, North Carolina.

${ }^{61}$ Cloninger interview, 2-3.
} 
Suddenly a firearm discharged in the darkness, followed by over 100 more shots from Charlotte police and perhaps several strikebreakers. Loy Cloninger averred that the strikebreakers were all quartered in the paint shop and took no part in the violence. Most of the streetcar workers laid the burden of guilt on Chief Orr and the police. However, since later court testimony corroborated strikebreakers shooting into the fleeing crowd, perhaps Cloninger could not account for all strikebreaker movements. ${ }^{62}$

Regardless of who opened fire on the crowd, flying bullets soon took effect among several demonstrators. Three Charlotte citizens were slain outright, with two victims more to follow. Neither Cloninger nor Ashe knew any of the shooting victims. Moreover, the newspapers differed as to some victims' names. Caldwell Houston, a Southern Railway engineer, crawled away to expire near the Dilworth laundry, where several witnesses found his body next morning. Claude Hinson, a teenage grocery clerk, fell instantly dead to the pavement. Walter (or William) Pope, newly arrived to Charlotte, had only been employed at one of the region's mills for three weeks. Machinist J.D. Aldrich (or Aldred) suffered five buckshot wounds to his abdomen; he would die the next morning after surgery. William R. Hammond of Fidelity Cotton Mill suffered a fatal shot through the throat, severing his spinal chord. Hammond died at age 36 on the following morning, leaving a widow and a four-year-old son. ${ }^{63}$

Shortly after the shooting incident, John W. Bridwell left the New Central Hotel to confer with the streetcar union. Several spokesmen told Bridwell their divisions had no role whatsoever in the Dilworth battle. Bridwell later reported thirty or so "armed

\footnotetext{
${ }^{62}$ Cloninger interview, 2-3.

${ }^{63}$ Raleigh News \& Observer, 26 August 1919, 1-3; Charlotte Observer, 26 August 1919, 1-2; 28 August 1919, 8; Charlotte News, 26 August 1919, 1; Cloninger interview; Ashe interview.
} 
professional strike breakers" staying at the car barn, "inviting trouble." One witness, combing the scene for injured people, later said a strikebreaker showed him "a hand full of new bullets," warning him there would be "more killing done." Witnesses also told the federal conciliator that the first gunshot came not from the protesters, as Chief Orr stated in the press, but from "some one in the car barn." Moreover, some of the gunshot victims had called out for aid, but only Sheriff Wallace and Deputy Fesperman offered them succor. Bridwell concluded this entire tragedy could have been avoided if Taylor had followed the position proposed by Mayor Frank McNinch. ${ }^{64}$

Meanwhile, Mayor McNinch hurriedly summoned six state National Guard units to restore order to his city. The first North Carolina guardsmen arrived from nearby Lexington at approximately 8 a.m. on August 26. That same Tuesday morning, hundreds of enraged citizens mobbed the Southern Public Utilities streetcars during their morning runs. Numerous arrests were made for obstruction and vandalism of property. John Temples, responsible for firing a slingshot through several streetcar windows, received a fine of $\$ 158.15$. Charlie Goodwin later served thirty days at hard labor for hurling a brick toward Assistant Superintendent T.H. Drum, dealing him a serious head injury. Drum also suffered rough treatment when sympathizers threw him off a streetcar. ${ }^{165}$

${ }^{64}$ National Archives and Records Administration, U.S. Department of Labor, Division of Mediation and Conciliation, Box 111, John W. Bridwell to Hugh L. Kerwin (26 August 1919); John W. Bridwell to Hugh L. Kerwin, telegram, 26 August 1919; John W. Bridwell to Hugh L. Kerwin $(27$ August 1919); Charlotte Observer, 19 October 1919, 7.

${ }^{65}$ One curious incident involved a U.S. Army assistant recruiter, Private Frey (or Fred) Yoe, caught wrecking a streetcar alongside strike sympathizers. Pvt. Yoe later faced court martial charges in Greensboro. (Raleigh News and Observer, 26 August 1919, 1-3; Charlotte Observer, 26 August 1919, 1-2; 29 August 1919, 4; 13 November 1919, 18; Charlotte News, 26 August 1919, 1, 13). 
In total, fourteen injured strike victims were taken to Charlotte hospitals. Thomas Head made an astounding recovery from two chest wounds, despite grim expectations. A.T. Baker and H.N. Seaman received abdominal wounds, while Lewis Wilson and George Smith's backs had been pierced by buckshot. Wilson's presence is noteworthy because he was listed as a North Charlotte weaver. Several other citizens, including Everett Wrenn and Walter Yandell, took bullets in their arms and legs. Clem Wilson, however, simply received first aid for his concussion wounds and left for home. ${ }^{66}$

To maintain "law and order," Chief Walter B. Orr circulated a warning through the Charlotte Observer and Charlotte News, concerning "the danger of rushing to the scene of any disturbance during the present street car strike." Orr's position became quite clear: "it is difficult for the police... to distinguish between active participants...and innocent spectators." Chief Orr's intimations of possible force worked to stifle further demonstrations in North Charlotte. ${ }^{67}$ Meanwhile, 600 National Guardsmen and militiamen patrolled central Charlotte for one week. One "Special Officer," David Ovens, later became a notable Queen City philanthropist and local politician. Before the strike, the Canadian-born Ovens had supported the right of workingmen to organize, but he felt these demonstrators had gone too far. Given a sidearm at the Charlotte Police armory, Ovens "hardly [knew] which end [of the gun] you fired from." His squad patrolled Dilworth, considered to be "the most vulnerable spot in town." 68

${ }^{66}$ Whether Lewis Wilson bore any kinship to Clem or John Wilson remains unclear. (Charlotte Observer, 27 August 1919, 1-2; Charlotte News, 26 August 1919, 1).

67 Raleigh News and Observer, 26 August 1919, 1-3; Charlotte Observer, 27 August 1919, 1-2; Charlotte News, 26 August 1919, 1.

${ }^{68}$ David Ovens, If This Be Treason (Charlotte: Heritage House, 1957), 130-2; Pease interview, Morrill, 1-3. 
Throughout the Queen City's crisis, the president of Southern Public Utilities remained buoyant. "I have carried my case to the people," Zebulon Taylor boasted on August 27. "They have placed their faith in the Power Company... [The people are] tonight patrolling the streets, waiting a possible riot call. There is no sympathy for the strikers." Taylor derided cooperative efforts by "Outside Instigators" to restore order following the strike. He blamed the "Amalgamated" for stirring up sympathizers, and asked "Citizens of Charlotte" if they would like to "welcome its permanent citizenship." Echoing Taylor's thoughts, ex-Governor Joseph "Little Joe" Brown of Georgia also wrote his own vicious diatribe against the AASERE, accusing them of conspiracy and murder across America. Taylor ensured Brown's telegram appeared in several regional newspapers after the violence to discourage sympathy. ${ }^{69}$

Mayor Frank McNinch also sought to punish Albert Jones, urging the Citizen's Committee to publicly retract its previous endorsement of AASERE Division 901. While McNinch later re-established friendly ties with the Charlotte Central Labor Union, he could not afford to seem in league with perceived agitators. On August 27, McNinch further approved laws permitting Southern Public Utilities' employees to carry firearms, citing an obscure Jim Crow statute reserved for race riots. This decision, in no small way, allowed the strikebreakers to persist in their intimidation of Charlotte townspeople. Despite his wartime popularity, the Democratic mayor now stood vulnerable to political opponents, who prepared petitions for his recall within hours of the Dilworth shootings. ${ }^{70}$

${ }^{69}$ Joseph M. Brown to Z.V. Taylor, telegram, 26 August 1919, reprinted in Charlotte Observer, 27 August 1919, 3; Raleigh News and Observer, 27 August 1919, 2; Greenville Daily News, 27 August 1919, 1; 28 August 1919, 4.

${ }^{70}$ Raleigh News and Observer, 28 August 1919, 1; Charlotte Observer, 27 August 1919, 3; 29 August 1919, 2; Charlotte News, 27 August 1919, 1, 4. 
In contrast, Southern Public Utilities Magazine took a less combative approach toward the strike. Estimating the costs at close to $\$ 500,000$, John Paul Lucas asked his readers: "What of the loss and inconvenience to the public?" He openly regretted the bloodshed, which he blamed on the "criminal bent of troublemakers on the outside of the local car men's organization." Without specific references to the company's gunwielding strikebreakers or the riotous textile workers, Lucas roundly decreed these shadowy "troublemakers" as neither representative of the striking car men, nor "the best element" of Charlotte's organized labor. These conciliatory gestures aside, Lucas also warned that unless organized labor is "purged" and controlled by the "fair-minded conservative element," the AFL would soon face rigid regulation by the federal government in order to restore "normal equilibrium.",71

Predictably, the Charlotte Observer took on a tone smacking of "I told you so." Blaming "false leadership" and "foreign influences," the Observer extended condolences to aggrieved families, while portraying the fallen as victims of "misrepresentation" and "class feeling." Charlotte Observer editors charged the city's Central Labor Union with the responsibility of policing their ranks of radicals. Charlotte News columnists decried "Red Terrorism" in the Queen City, accusing the AASERE of interference with Southern Public Utilities' peaceful "operatives of the cars." Essentially, both newspapers rendered lip service to theoretical rights of organized labor while condemning actual unions for attempting to practice these freedoms. In contrast, both newspapers also praised the “courageous" actions of Charlotte policemen under Walter B. Orr's command. ${ }^{72}$

\footnotetext{
${ }^{71}$ Southern Public Utilities Magazine, Vol. 5, No. 4, 15 September 1919, 1-4, 17-19.

${ }^{72}$ Charlotte Observer, 27 August 1919, 3; Charlotte News, 26 August 1919, 4.
} 
News of Charlotte's short, bloody insurgence traveled across the nation, even appearing briefly in the New York Times. Most regional newspapers remained curiously detached from Charlotte's affairs. Raleigh's News \& Observer and Columbia's The State covered the immediate events, but neither state capital newspaper offered much opinion. Charles O. Hearon's Spartanburg Herald focused more on national strikes. Calvin Hemphill's Journal \& Carolina Spartan noted one of the Charlotte National Guard officers, Army Lieutenant M.G. Caldwell, had led a South Carolina infantry unit in France. The Greenville Daily News merely reprinted Charlotte editorials and Zebulon Taylor's company diatribes. ${ }^{73}$

Not every news editor throughout the region accepted the national streetcar union as a convenient scapegoat. From the northern end of the Carolina Piedmont, the Greensboro News proclaimed drily that "the law in Charlotte... is still supreme." Citing a recent Charlotte lynching in which Walter Orr's officers failed to protect a single "wretched Negro," the Greensboro editor derided the Charlotte police for their willingness to kill its own citizens in order to protect Southern Public Utilities streetcars. He concluded that the Charlotte strike had been "a sorry exhibition all round," blaming Zebulon Taylor for his "contemptuous" rejection of compromise. ${ }^{74}$

${ }^{73}$ Journal \& Carolina Spartan, 28 August 1919, 1, 8; Spartanburg Herald, 27 August 1919, 1, 5; New York Times, 27 August 1919, 2; Raleigh News and Observer, 27 August 1919, 2; Greenville Daily News, 26 August 1919, 1-2; 28 August 1919, 3-4; 29 August $1919,15$.

${ }^{74}$ Greensboro may have had other reasons to condemn Southern Public Utilities. Greensboro's own utility company was embroiled in an anti-trust lawsuit that had reached the state Supreme Court. ("The Public Loses," from Greensboro News, reprinted in Greenville Daily News, 29 August 1919, 15; Henry C. Spurr, Public Utilities Reports Annotated, Rochester, New York: Public Utilities Reports, Inc., 1920, 688-713). 
Columbia's Labor Advocate also covered the Charlotte strike from Marvin Ritch's courthouse speech onward. Editor Charles Henry held Taylor liable for engineering the whole incident, having ignored pleas from the Chamber of Commerce and the Rotary Club of Charlotte. However, Henry concerned himself more with the strike's localized effects in Greenville, South Carolina, where conciliator John W. Bridwell described an "acute" situation developing since August 26. Taylor later admitted he had contemplated sending replacement workers to operate his cars in Greenville. However, no Southern Public Utilities cars ran there for one week, nor did they operate in Winston-Salem. ${ }^{75}$

One reason why Taylor may have reconsidered his strategy became apparent soon after the Dilworth incident. Taylor's professional strikebreakers demonstrated a disturbing penchant for hair-trigger violence, even while National Guardsmen lingered in the city. On Saturday, August 30, one streetcar ran through the wealthy residential sector of Myers Park, Taylor's one-time neighborhood. Its operators were allegedly “trainers," lacking the experience to handle the brakes. When the Southern Public vehicle went off track, a nearby group of carpenters interrupted their work long enough to jeer at the crewmen. In reply, these strikebreakers opened fire with their handguns. Bullet holes were plainly evident at one private residence. Taylor fired the offending streetcar men, but condemned the carpenters for their "very provoking" behavior. While the Charlotte

75 This weekly paper enjoyed only sporadic distribution for two years, changing its title to Trade Review in October 1919 before disappearing from circulation after April 1920. (Columbia Labor Advocate, 22 August 1919, 1; 29 August 1919, 6; 5 September 1919, 1; National Archives and Records Administration, U.S. Department of Labor, Division of Mediation and Conciliation, Box 111, John W. Bridwell to H. L. Kerwin, letter, 30 August 1919). 
Observer dutifully reported this Myer Park incident, their journalists and editors downplayed its darker ramifications. ${ }^{76}$

Greenville's platform men were the first to surrender their strike on September 2, after meeting with H.E. "Smoke" Thompson of the South Carolina Arbitration Board. Charlotte streetcar workers settled with Southern Public Utilities on September 5, while Winston-Salem followed on September 6. Zebulon Taylor honored the strikers' central requests for overtime hours and a graduated pay scale to 43 cents per hour. Taylor also promised no discrimination toward former strikers, providing they were not involved in the Dilworth riot. Jesse B. Ashe later recalled that Superintendent Wommack discharged a few troublemakers, but the company permitted the remainder, like prodigal children, to return to its fold. Despite such magnanimity, Taylor also underscored the benefits of loyalty and servility when he subsequently rewarded Anderson's steadfast men preferential assignments and markedly higher wages, at $461 / 2$ cents. $^{77}$

Federal Conciliator John Bridwell had temporarily vacated Charlotte on August 30 when the news of Greenville's capitulation reached him in Atlanta. Returning just in time, Bridwell played a leading role in the settlements offered Charlotte and WinstonSalem's workers, who received slightly better arrangements than their compatriots in Greenville. Total raises averaged about 9 cents hourly. Bridwell consequently believed his role in the Carolinas almost complete, having "went further" than previous labor hearings to secure a favorable compromise. Forty Southern Public electricians under D.

\footnotetext{
${ }^{76}$ Charlotte Observer, 30 August 1919, 3.

77 Southern Public Utilities Magazine, Vol. 5, No. 4 (September 1919), 22; Charlotte Observer, 5 September 1919, 1-2; Columbia Labor Advocate, 5 September 1919, 1; Ashe interview.
} 
L. Goble still remained on strike, hoping for full union recognition, but Bridwell predicted they would fare no better than had the company's 163 streetcar employees. $^{78}$

In late August, Solicitor John W. Abercrombie of the Labor Department also received a telephone call from U.S. Senator Lee Overman of North Carolina. Overman also sent a formal request to investigate the Charlotte situation, hoping for a mutually beneficial adjustment. Taylor certainly did not desire greater federal scrutiny, so this might also explain his expedited labor resolutions, as well as his decision in early September to discharge his remaining strikebreakers in anticipation of a settlement. ${ }^{79}$

Albert E. Jones played no further role in the strike negotiations with Southern Public Utilities Incorporated. John Bridwell confirmed Southern Public streetcar workers in Charlotte, Winston-Salem, and Greenville had reached their agreements in exchange for yielding national recognition. Nevertheless, Jones reported a complete union victory in all three instances, gestures that researcher Carol Shaw describes as "face-saving cries in the wind." One also senses a policy of damage control at work. Motorman and Conductor's first inkling of Charlotte's trouble arose during the AASERE's Seventeenth Convention. On 11 September, President William Mahon briefly announced that Jones had just reported from Charlotte, where a "very serious situation existed." Mahon also demonstrated his near-complete detachment from the whole affair, characterizing the strike as being against three separate companies instead of one major corporation.

\footnotetext{
${ }^{78}$ National Archives and Records Administration, U.S. Department of Labor, Division of Mediation and Conciliation, Box 111, John W. Bridwell to H. L. Kerwin, letter, 4 September 1919; John W. Bridwell to H. L. Kerwin, letter, 5 September 1919; John W. Bridwell to H. L. Kerwin, letter, 7 September 1919.

${ }^{79}$ National Archives and Records Administration, U.S. Department of Labor, Division of Mediation and Conciliation, Box 111, John W. Bridwell to H. L. Kerwin, letter, 30 August 1919; Senator Lee Overman to John W. Abercrombie, letter, 28 August 1919.
} 
This would suggest Jones, as a Special Organizer, enjoyed broad authority and very little supervision throughout these proceedings. In fact, Jones benefited from involvement in the Carolinas, receiving his promotion to $11^{\text {th }}$ Vice President that same year. ${ }^{80}$

North Carolina Lieutenant Governor O. Max Gardner supervised the restoration of order in Governor Bickett's absence. North Carolina troops soon demobilized, departing Charlotte on the first of September. Zebulon Taylor agreed to release Southern Public's "trainers" from their contracts, in anticipation of settlements with his workers. Yet, despite these tentative steps toward normality, Charlotte did not recover immediately from its summer of mistrust and class conflict. When the streetcars resumed their accustomed runs, the North Charlotte lines were pointedly left without service for weeks to come. ${ }^{81}$

During these watchful days, state and county officials launched their inquest concerning the Dilworth shootings. Meanwhile, the Central Labor Union engaged Jake Newell to represent their cause in the courts. However, these legal procedures proved to be fraught with controversy. Even a cursory investigation would reveal the Charlotte police's excessive use of force. Newspaper accounts indicated no policemen or strikebreakers reported injuries sustained during the "Battle of the Barn." This fact John Bridwell also confirmed to his supervisor in Washington. Moreover, Dr. J.R. Alexander of Presbyterian Hospital would swear that only one of the five dead men had suffered from frontal gunshot injuries. This would suggest the police fired at fleeing protestors,

${ }^{80}$ Motorman \& Conductor, September 1919, 78, 144; National Archives and Records Administration, U.S. Department of Labor, Division of Mediation and Conciliation, Box 111, John W. Bridwell to H. L. Kerwin, letter, 30 August 1919; Shaw, 66.

${ }^{81}$ Raleigh News and Observer, 30 August 1919, 1-2; Charlotte Observer, 30 August 1919, 1; Shaw, 47-48, 59. 
and not the angry, charging mob that Chief Walter Orr described on the night of August 25. However, no one drew much attention to this fact in subsequent courtroom testimony, nor did the major newspapers interview surviving gunshot victims. ${ }^{82}$

Initially, the Mecklenburg County Coroner, Z. A. Hovis, dragged his feet, rescheduling the official inquest from August 28 to September 2, one week after the slayings. Jake Newell grew impatient when this date fell through, and he expressed his personal doubts to Governor Thomas Bickett. Evidently, Hovis had fallen ill on the inquest date, as had the clerk of court responsible for naming a deputy. Moreover, another deputy coroner had been disqualified on a technicality. Newell professed his desire to "discover the truth," whether it exonerated or implicated his clients. He also attested to "two hundred or more witnesses" who could speak of strikebreaker involvement at Dilworth. He also alleged Chief Walter Orr fired his sidearm first. Newell concluded his letter with a plea for full state investigation. However, little evidence exists to suggest Governor Bickett wanted to interfere in what was widely perceived as local politics. $^{83}$

Moreover, Raleigh's access to evidence appears to have been greatly limited. Days after North Charlotte's uprising, the Raleigh News-Observer still reported John Wilson as the chief culprit. However, by this point, Charlotte police reports indicated Wilson carried no weapons. Nevertheless, many conservatives were anxious to make an

\footnotetext{
${ }^{82}$ National Archives and Records Administration, U.S. Department of Labor, Division of Mediation and Conciliation, Box 111, John W. Bridwell to Hugh L. Kerwin, letter, 27 August 1919; John W. Bridwell to Hugh L. Kerwin, letter, 30 August 1919; Charlotte Observer, 20 October 1919, 4; Charlotte News, 26 August 1919, 1.

${ }^{83}$ National Archives and Records Administration, U.S. Department of Labor, Division of Mediation and Conciliation, Box 111, Jake Newell to Gov. Thomas H. Bickett, letter, 3 September 1919.
} 
example of unruly North Charlotte. Carol Shaw's research hints that Southern Public Utilities had sought to "press the textile workers into submission." Before a grand jury, John Wilson received a lesser charge of inciting a riot, and subsequently left jail on a \$2000 bond. Mecklenburg County, stung by Wilson's release, approached the North Carolina Attorney General to prosecute John Wilson's impending trial in late September. However, in keeping with Raleigh policy, the state's attorney, John Hall Manning, believed local courts would find the truth "when the public is less excited." 84

So, if John Wilson did not carry a gun, then who fired the shot that triggered the "Battle of the Barn?" During Wilson's preliminary hearing, Chief Orr would describe someone close to the defendant raising a handgun. The chief's own sidearm subsequently got caught on his thumb, "discharging into the air." ${ }^{85}$ Sheriff Newt W. Wallace believed the mystery shot came from Chief Orr's left -- perhaps toward the shop, where strikebreaking crewmen had taken cover. Plummer Stewart, John Wilson's defender, keenly scrutinized the role of Taylor's men. However, only one patrolman, Officer McKnight, corroborated the strikebreakers' involvement during the firefight. ${ }^{86}$

After John Wilson's arraignment and bail, a legal impasse in Mecklenburg County Superior Court threatened to ensue. Charlotte's Labor Council, representing each trade union, made formal charges of murder and conspiracy against Chief Orr's staff and twenty-seven of Taylor's strikebreakers. However, the Charlotte police force refused to

\footnotetext{
${ }^{84}$ National Archives and Records Administration, U.S. Department of Labor, Division of Mediation and Conciliation, Box 111, Jake Newell to Gov. Thomas H. Bickett, letter, 3 September 1919; Raleigh News and Observer, 30 August 1919, 1-2; Charlotte Observer, 5 September 1919, 1-2;; Charlotte Observer, 5 September 1919, 1-2.

${ }^{85}$ Charlotte Observer, 5 September 1919, 1-2.

${ }^{86}$ Raleigh News and Observer, 26 August 1919, 1-3; Charlotte Observer, 18 November 1919, 9-10.
} 
serve these subpoenas, obviously out of concern they could be implicated in the courts. ${ }^{87}$ Jake F. Newell, representing the chief plaintiff, Clem Wilson, fought to have these subpoenas released in order to force the strikebreakers into court. On September 1, chief strikebreaker T.J. Fitzgibbons had earlier faced charges for the shooting of Caldwell Houston, but five witnesses were unable to conclusively identify Fitzgibbons during his preliminary hearing. ${ }^{88}$ Unquestionably, the resultant Charlotte Police Trial diverted press attention from John Wilson, whose own defense against conspiracy charges encountered “woefully slow progress” in Mecklenburg County Superior Court.

North Carolina Attorney General Manning soon held a conference with Charlotte officials and labor unions, and supported Jake Newell's case for a lawsuit. Newell vowed to personally swear the warrants over any police objections, but he held back the warrants until the mayoral recall election, to avoid political complications. Ultimately, fifteen strikebreakers and 31 police officers, including Chief Walter Orr, stood accused of murder by Charlotte's Labor Executive Board. Newell had won his request for a full courtroom enquiry, but Orr welcomed such an investigation, maintaining his story. ${ }^{89}$

The outcome of the Charlotte Police Trial hinged upon the political fortunes of their incumbent mayor. During an October 21 recall vote, Mayor Frank R. McNinch won a sweeping victory, with a margin of 1,433 votes against J. Frank Flowers out of a total of 5,273. ${ }^{90}$ During their single public debate on October 11, McNinch sparred with his Republican opponent. Ridiculing the fact Frank Flowers had not been present during the

${ }^{87}$ Charlotte Observer, 24 October 1919, 4.

${ }^{88}$ Charlotte Observer, 2 September 1919, 2; 24 October 1919, 4; Charlotte News, 3 September 1919, 1.

${ }^{89}$ Ironically, at least five Charlotte policemen were former streetcar men. (Columbia Trade Review, 24 October 1919, 3; Charlotte Observer, 13 October 1919, 4).

${ }^{90}$ District voting trends are unavailable. (Charlotte Observer, 22 October 1919, 1). 
crisis of August 26; McNinch mocked the lawyer for missing his chance to be a "terrifying-looking policeman." ${ }^{.91}$ McNinch also publicly deprecated "the mobocracy" of organized labor in order to stay in office, but behind the scenes, the mayor consistently strove for a course of moderation. McNinch's speech to the State Federation of Labor on 9 August 1920 stated his opposition to "class government," either by employers or workers. His tough stance in 1919 had been primarily directed at "dangerous... radical leadership," although McNinch did not directly implicate individuals. Mayor McNinch not only supported rights of organized labor, but felt such worker's organizations, under "thoughtful and conservative leadership" would serve the "general good."

Despite McNinch's political victory, his opponents sought to make him squirm. On October 22, fifty-eight warrants were served to Chief Walter B. Orr's men and those strikebreakers not already discharged by Southern Public Utilities. Republicans forced these summonses to overshadow McNinch's triumph. However, these subpoenas proved difficult to serve, for many of Zebulon V. Taylor's hirelings had fled to other parts of North Carolina, or down toward Georgia and South Carolina. Eventually, twenty former strikebreakers, including T. J. Fitzgibbons, stood in the docks once more in Charlotte. ${ }^{93}$

Meanwhile, a war of words ensued in Charlotte, threatening to fan the flames once more. Shortly before his defeat on October 21, J. Frank Flowers had denounced Police Chief Walter B. Orr for the five "unlawful deaths" at Dilworth. In return, the Observer accused Flowers of cowardice. Thereafter, a brief editorial battle sparked

\footnotetext{
${ }^{91}$ Charlotte Observer, 11 October 1919, 2.

${ }_{92}$ Charlotte Observer, 9 August 1920, 1; Greenwood, 129.

${ }^{93}$ Charlotte Observer, 23 October 1919, 4.
} 
between Charlotte Observer and the local worker's paper, Charlotte Labor Herald.$^{94}$ Chief Orr's court statement (endorsed by thirty-three policemen) made print in the Observer beside twelve 'anonymous' Labor Herald reports. ${ }^{95}$ If Flowers's witnesses withheld their identities, then perhaps they had good reasons to do so. Chief Walter B. Orr had many powerful supporters in Charlotte. During this era of renewed Ku Klux Klan, witness intimidation, even death threats were common occurrences, especially if one questioned the established order. One did not need to be African-American to risk this new Klan's hatred of organized labor. Because the Charlotte Observer sought to make straw men of labor witnesses, official summaries often discounted their testimony.

Two witnesses said Chief Orr allowed the crowd's taunts to provoke his temper. Just after John Wilson accosted the chief, someone in the crowd mocked Orr for being such a "nice chief." Orr allegedly said "I'll show you what kind of a chief I am," before firing his rifle -- most reports describe Orr firing his sidearm in the air. But it is possible that Orr may have carried both rifle and pistol; Officer Thomas Merritt, Clem Wilson's actual assailant, certainly did. This would also suggest Chief Orr had come looking for a quarrel. Orr's former superior, Sheriff Newt Wallace, also had the difficult position of defending his former protégé's actions. He acknowledged "considerable cursing" among the demonstrators, and that one had pronounced the chief a "son of a bitch" who had struck Clem Wilson. But despite his earlier testimony that the demonstrators had been unarmed, Wallace now agreed that someone had fired to his left. ${ }^{96}$

\footnotetext{
${ }^{94}$ Charlotte Observer, 24 October 1919, 4, 6-7.

${ }^{95}$ Unfortunately, this pro-labor newspaper no longer seems to exist in the largest Mecklenburg County archive at the Charlotte Downtown Public Library. (Charlotte Observer, 19 October 1919, 7).

${ }^{96}$ Charlotte Observer, 19 October 1919, 7.
} 
As the rhetoric against Chief Walter Orr escalated, the Mecklenburg County Superior Court threatened to transform John Wilson into a scapegoat. On the first of October, Solicitor George Wilson (no relation) shackled the hapless prisoner with two conspiracy charges. Another magistrate, John Shaw, turned the court proceeding into a bully pulpit against labor movements, heedless of the fact John Wilson had carried no weapon on August 26, nor held any known union memberships. ${ }^{97}$ All the while, attorneys Edward T. Cansler and J.D. McCall coordinated Chief Walter Orr's defense set for November.

Edward Cansler, a notable orator, had recently prosecuted Marvin L. Ritch in Albemarle, North Carolina. Following the Dilworth incident, Ritch received several threats promising violence if he did not leave Charlotte. Yet, Ritch persevered in his advocacy for textile workers. On September 15, Ritch had organized two thousand textile workers in a strike against Wiscasset Mills. Stanly County policemen suppressed the picketers, one of whom received a mortal gunshot wound. Wiscasset strikebreakers joined in the fray, wielding axe-handles, while their opponents fought back with rotten eggs. Ritch faced scorn in Charlotte, but later paid a fine. Ann R. Brantley, Ritch's daughter, recalls that a prominent Stanly County citizen actually paid Ritch's bail. ${ }^{98}$

Now it was Ed Cansler's turn to feel the squeeze. Prosecutor Jake Newell fenced with Cansler for several days, providing Charlotte with a colorful clash of legal minds. Even Charlotte Observer reporters had grudging praise for the "wily" Newell's crossexamination. Several eyewitnesses testified that Chief Orr's unrestrained use of his

\footnotetext{
${ }^{97}$ Charlotte Observer, 30 September 1919, 14; 1 October 1919, 4

${ }^{98}$ Charlotte Observer, 24 September 1919, 1; 20 November 1919, 1; Lumberton Robesonian, 24 November 1919, 4; Brantley interview.
} 
police revolver precipitated the "Battle of the Barn." R.C. Frazier stated the chief pushed a man away, brandishing his handgun. "Get back or I'll kill you," were Orr's alleged words, C.K. Coleman recalled when the shots began, strikebreakers poured out of the powerhouse to join the gunfight. Other reports indicated the crowd fought with mere stones, liquor bottles and baseball bats. All but two victims had been shot in the back. ${ }^{99}$

On November 21, Assistant Prosecutor John J. Parker forced Chief Orr to concede discharging the first shot. Several officers verified their leader fired upward and away. Orr justified his conduct, stating thirty police officers could not have arrested the demonstrators yet still preserve order. The chief thought he saw a gun in the crowd, maintaining he raised his own weapon to protect his face -- accidentally pulling the trigger. ${ }^{100}$ This statement remains at variance with Orr's first statement denying that he fired, yet no charge of perjury would ever be leveled against the Charlotte police chief.

Reviewing the case from hindsight, one also should raise questions about Orr's reckless endangerment of Dilworth's citizens. Although they were both children at the time, Myrtle B. Teague, and her sister, Frankie B. Graves, recalled the nighttime events of August 25. Their father, Taylor Baker, had been a Southern Public Utilities motorman for many years. On the night in question, fifteen-year-old Myrtle Teague and six-yearold Frankie "heard the bullets hitting the screens," outside their bedroom window. Frank Lethco also reported bullets "coming right toward [his] house," located across the street from the streetcar barn. One of the slain men actually fell before Lethco's dining room window. Finally, an unsubstantiated account from one of J.F. Flowers's eyewitnesses

\footnotetext{
${ }^{99}$ Charlotte Observer, 20 November 1919, 4.

${ }^{100}$ Charlotte Observer, 22 November 1919, 4.
} 
claimed that a Mrs. Smith of Louise Avenue was indeed injured by a stray bullet, and taken to an undisclosed hospital by her husband. ${ }^{101}$

Between Chief Orr's contradictory statements and the real possibility of further lawsuits against the police force, Mecklenburg County faced a serious dilemma. Should Chief Orr incriminate himself further, the city of Charlotte might be held accountable for five deaths. On November 23, Superior Court justices F.B. Alexander and J. Lee Sloan moved to exercise damage control. The two justices summarily dismissed the prosecution's charges against Chief Orr. "Whatever verdict we might render... would subject us to an immense amount of criticism," Alexander ruled. "That a very unfortunate tragedy has happened in Charlotte cannot be denied," he added. "There must be some latitude... left to the parties, else we may as well put a dummy on the bench."102

Moreover, the courts refused to charge Clem Wilson for court costs. "We cannot adjudge the [legal] action was frivolous and malicious... [The plaintiff] had a right to come into the courts." Yet Judge Alexander also believed "those five mounds in the cemetery... do not have to be marked by gravestones to refer to this for ages to come... we have to take into consideration [those] responsible for the misfortunes." Rather than blame the living, the Mecklenburg Courts placed culpability on the five dead men, to prevent them from becoming martyrs. ${ }^{103}$ The sensational Charlotte Police Trial was over. Apparently, the Queen City wished to put this unpleasant occurrence behind them. Even the Charlotte Observer made no further mention of the strike, following the

\footnotetext{
${ }^{101}$ Charlotte Observer, 14 October 1919, 4; 19 October 1919, 7; Steven Snow, “Trolley Holds Deep Memories," from Charlotte Observer, Mecklenburg Neighbors, 14 January 1987, 10C.

102 Charlotte Observer, 23 November 1919, 4.

103 Charlotte Observer, 23 November 1919, 4; Columbia Trade Review, 12 December, 1919, 1.
} 
courtroom verdict of November 23. John Wilson's fate remains unclear, given the absence of complete trial records. According to Carol Shaw, Wilson faced trial in criminal court in September, yet no mention is made of such a trial. At worst, one can hope Wilson may have received hard labor or fines, if not outright acquittal. ${ }^{104}$

According to Fritz Lang's Metropolis, “the mediator between head and hands must be the heart!" If so, why did this "very unfortunate tragedy" occur in North Carolina's own metropolis? Zebulon Vance Taylor, the head of Southern Public Utilities Company, undermined hope for compromise. The executive had no qualms about employing big-city strikebreaking tactics, circulating defamatory propaganda, while recruiting a private army to crack down on his rebellious workers. Beyond question, these heavy-handed methods got big-city results. In so doing, Taylor demonstrated a lack of compassion toward his workers, despite his outward professions of generosity.

Furthermore, Zebulon Taylor showed disrespect and contempt toward his progressive colleagues, who had all but hammered out a trial contract recognizing the streetcar union for one year. In so doing, Mayor Frank McNinch and Public Works Commissioner Arthur H. Wearn affirmed the right of local workers to unionize, even as they gestured to regional mistrust by excluding organizer Albert Jones from the discussions. Taylor not only slighted Mayor McNinch, but other commission members, such as W.S. Alexander, C. A. Williams, and Clarence O. Kuester - respected city leaders. Seventy-five years later, Clarence Kuester, Jr. remembered his father's horror when he came back from the scene on South Boulevard and Bland Street. "Booster" Kuester had earned his reputation as "a great diplomat," preferring to "smooth matters

104 Charlotte Observer, 29 September 1919, 7; 13 November 1919, 18; Shaw, 45. 
over and for people to get along." Thereafter, the Charlotte leader recalled the strike with bitter disappointment. ${ }^{105}$

One could liken Taylor's refutation of the August 23 commission decision to an absolutist monarch defying a parliamentary decree. Obviously, Taylor did not recognize municipal or state authority when it contradicted his business policy. Perhaps Taylor's own past as Greensboro mayor gave him the impression he knew what was best for the Queen City. If not for Taylor, Charlotte, Winston-Salem, and Greenville might well have followed the successful union model of Columbia, South Carolina. As one Charlotte historian, David Goldfield, remarked in 1994, "Civility, not conflict, characterizes the decision-making in the corporate culture of Charlotte." Most historians, from Carol Shaw to Dan Morrill, tend to agree the local union men and city officials acted with civility, leading up to Taylor's deployment of strikebreakers on August 24. ${ }^{106}$

While David Goldfield's assessment of Charlotte business may ring true in modern times, this research into Charlotte's history does not substantiate any such claim during the first part of the twentieth century. One could hardly describe Edward Latta's high-handed actions in 1903 as an example of cordiality and gentlemanly conduct toward his workers. Unless “civility” is defined by Wade Harris's vicious newspaper attacks, Zebulon V. Taylor's browbeating tactics, or Chief Walter Orr's excessive violence, then one should look elsewhere. While Mayor Frank McNinch and Clarence Kuester acted in good faith, they unfortunately lacked the clout to make a crucial difference in preventing the Charlotte tragedy.

${ }^{105}$ Richard Maschal, "Forgotten Night of Fear," from Charlotte Observer, 23 August 1994, 1E-2E.

${ }^{106}$ Charlotte Observer, 23 August 1994, 1E-2E; Shaw, 56-66. 
Without local support, Charlotte's AASERE Division 901 gradually withered on the vine. In March 1922, the Charlotte streetcar union formally disbanded due to low membership. Ultimately, the defeat of streetcar workers in Charlotte meant a major setback to regional forces of labor - particularly streetcar unions. Within scant weeks of Charlotte's debacle, Knoxville, Tennessee, experienced its own streetcar strike, leading to another defeat. Reverses in South Carolina and Georgia also occurred. Readers should also keep in mind the simultaneous struggle for textile mill workers in the Carolina Piedmont. Even while Charlotte's public transportation lay paralyzed in that summer of 1919, Palmetto textile mills in Rock Hill and Aragon struck for higher wages. Then, Marvin Ritch led the disastrous strike at Wiscasset Mills, in Albemarle County, North Carolina, in September. Over 6,000 textile workers participated in autumn strikes as widespread as Macon, Georgia, and High Point, North Carolina. Quelled by Georgia state police, Macon strike leaders faced jail sentences, while North Carolina Governor T.W. Bickett personally resolved the High Point strike. ${ }^{107}$

Almost a decade would pass before unionism recovered sufficiently for future recruitment drives in the Upper Carolinas. By then, electric streetcars were in decline, and the AASERE presence in the Carolinas a mere shade of its former self. The next chapter will chiefly examine the subsequent reversals of streetcar unionism in Spartanburg and Columbia, South Carolina. In the latter case, Division 590 experienced two strikes, a brief contractual argument in February 1920 and a more serious lockout, beginning in January 1922. But Charlotte's immediate effects may well have affected the outcome of October 1919's streetcar strike in Knoxville, Tennessee - a major

${ }^{107}$ Motorman and Conductor, Vol. 31, No. 4 (March 1922), 8; Labor Advocate of Columbia, 22 August 1919, 1; 19 September 1919, 1. 
Appalachian town known for its coal-mining operations. Moreover, Spartanburg's reversals in early 1920 require further assessment in light of the outcome of Charlotte's "Battle of the Barn." 
Columbia, a city of 40,000 during the 1920 s, today serves as a gateway to the Upcountry textile mill region. Once a major labor stronghold in the South, Columbia ultimately proved to be the last major battleground for streetcar labor. Under new postwar leadership in 1920, the Columbia Railway, Gas, and Electric Company (CRG\&E) sought to eliminate their streetcar union, Division 590, ostensibly as a costcutting measure. Meanwhile, a strengthening anti-labor climate in Columbia revealed a deeper peril for unionism. It would be too simplistic to view this chapter merely as a Gotterdammerung for the Amalgamated Association of Street and Electric Railway Employees. Instead, Columbia's episodic strikes in 1920 and 1922 should be interpreted as a symptom of general decline in South Carolina's urban labor culture.

Throughout the Charlotte regional strike, Columbia's labor community kept abreast of developments. Charles Henry of the Labor Advocate continued his support for conservative labor politicians. His newspaper endorsed Democrat John Hughes Cooper during an off-year Congressional election in 1919. Long a supporter of unionism, John Hughes Cooper also won favor among Greenville textile workers for his opposition to immigration. Two other Upcountry pro-labor candidates, Colin Monteith and George B. Timmerman, also relied on mill supporters in the 1920 state elections. In 1918, AASERE Division 590 president Ambrose A. Gerald and his lieutenant, William D. Hampton, had each won seats in 1918 as South Carolina legislators, representing Richland County. ${ }^{1}$

\footnotetext{
${ }^{1}$ Motorman and Conductor, November 1918, 1; Labor Advocate of Columbia, 8 August 1919, 5; 15 August 1919, 4, 7.
} 
Initially, Division 590 of Columbia, like most of its local counterparts, remained distantly sympathetic toward the Charlotte strikers. There were no demonstrations in Columbia, nor were there specific editorials concerning the major strike occurring to their north. However, the tense events of August 1919 were still on the minds of labor leaders. On Labor Day, Columbia's workingmen chose to observe the holiday without any demonstrations or parades, ostensibly to enjoy a peaceful holiday with their families. One week after Labor Day, Charles Henry saluted "Lucky Columbia" for escaping "strikes, riots, dissentions (sic), and chaos." Henry likely meant the Labor Day violence of Centralia, Washington, but once more, Charlotte loomed in the regional backdrop. Charles Henry also reminded his readers that "Employer and Employee have learned that it is more profitable to grasp the hand than the throat of each other." 2

In October 1919, Charles Henry, the self-styled "Conservative Labor Leader," assailed the "carnival of strife" fomented by Bolshevik radicalism across the nation. In this spirit, Henry renamed the Labor Advocate of Columbia, perhaps as a gesture toward the country's gathering anti-labor atmosphere. Until January 1920, Henry published the Trade Review, a rather bland, non-confrontational masthead if ever there was one.

Despite this shift in attitudes, Henry still supported the local streetcar union of Columbia. That same month, the Trade Review boasted the benefits of organization, citing Division 590's decade-long record of 9-hour workdays, competitive wages peaking at 44.5 cents, seniority benefits, and arbitration guarantees. Henry also commented on high worker morale, with very few accidents and low turnover rates. ${ }^{3}$

\footnotetext{
${ }^{2}$ Labor Advocate of Columbia, 8 August 1919, 4; 22 August 1919, 4; 12 September $1919,4$.

${ }^{3}$ Trade Review of Columbia, 17 October 1919, 5; 24 October 1919, 2.
} 
On October 7, the very same day Charles Henry extolled Columbia's streetcar service, AASERE Division 767 struck after Knoxville Railway and Light Company (KRL) refused to renew a favorable contract brokered in August 1918 by the National War Labor Board. KRL manager Charles H. Harvey, in a feat of legal legerdemain, reasoned that his workers would have to take their contractual grievances up with the NWLB, an organization that no longer existed by October 1919. Like Charlotte's recent upheaval, the Knoxville strike erupted into violent demonstrations after Harvey, sent armed strikebreakers - including ex-WWI soldiers -- to man his streetcars. Strike sympathizers, aided by the local policeman's union, clashed in late October with vigilante groups led by the local Tennessee Law and Order League. Historian James A. Burran also underscores the complications of Knoxville's recent race riot, plus an ongoing coal mine strike in Kentucky and East Tennessee. Hostilities did not cease until Tennessee Governor Albert Roberts mobilized troops from Camp Gordon, Georgia. ${ }^{4}$

Burran's research does not correlate to similar events in the Carolina Piedmont, but one may assume Knoxville did not exist in a vacuum in 1919. Henry's Trade Review noted a meeting of the Tennessee Labor Convention just before the Knoxville strike, which Burran speculates may have inspired Division 767 toward militancy. Moreover, Columbia's labor paper covered the strike's particulars, including the city's decision to ban public displays or parades in an effort to quell labor sympathizers. ${ }^{5}$

\footnotetext{
${ }^{4}$ James A. Burran, "Labor Conflict in Urban Appalachia: The Knoxville Streetcar Strike of 1919," from Tennessee History Quarterly, Spring 1979, 62-78; National War Labor Board, Docket No. 251, in re Employees Members of Division No. 767, Amalgamated Association of Street and Electric Railway Employees of America $v$. Knoxville Railway and Light Company, Washington Government Printing Office, 1919.

${ }^{5}$ Burran, 62-78; Trade Review of Columbia, 31 October 1919, 1.
} 
By 1920, Knoxville's Division 767, established in September 1917, had ceased to exist in all but name. Most of its membership had already sought other employment. Shortly after the Knoxville strike, the city railway company fell into receivership. Knoxville's defeat of streetcar labor in some ways mirrors the outcome in Columbia, South Carolina's 1922 strike. However, this labor defeat still lay ahead when Charles Henry blithely forecasted "the wave of industrial unrest [had] reached its crest, and is now on the wane." Endorsing Woodrow Wilson's measures to investigate labor grievances, Henry blamed the U.S. Congress for inactivity and "war-profiteering" capitalists for its intolerance of responsible labor unions. ${ }^{6}$

Soon after, Charles Henry's influence in Columbia ended when the Trade Review of Columbia passed into different hands in 1920. Reasons for this transition have been lost with passage of time. Given the forthcoming changes in the weekly paper's format, one might guess finances might have been a major factor. Throughout the paper's short existence, Henry consistently exhorted his readers to advertise their business in his newspaper. But, following the holiday issue of 26 December 1919, C.H. Parks took over as editor, and T.A. Wilson became Trade Review's publisher. By April 1920, T.A. Wilson took over permanently as both editor and publisher of a reduced bimonthly labor newspaper, numbering only four pages. Reductions could not save the paper; Columbia Trade Review seems to have vanished by the end of $1920 .^{7}$

\footnotetext{
${ }^{6}$ Motorman and Conductor, Vol. 26, No. 3 (February 1918), 21; Vol. 28, No. 7 (July 1920), 10-11; Trade Review of Columbia, 28 November 1919, 2; 5 December 1919, 1-2; Philip S. Foner, History of the Labor in the United States: Volume VIII: Postwar Struggles, 1918-1920 (International Publishers, New York City, 1988), 106-108.

${ }^{7}$ University of South Carolina at Columbia's Caroliniana Library only has selected issues of Labor Advocate and Trade Review, many of the latter collected and donated by Professor Snowden. Charleston also had its own labor newspaper at this time, the Labor
} 
In late January 1920, Columbia witnessed a brief walkout of AASERE Division 590 over the Columbia Railway, Gas, and Electric Company's renewal of their annual contract. Interestingly, in January 1920, Franklin H. Knox had assumed the presidency of CRG\&E, replacing Edward Robertson, who had respected the union's request for a contractual guarantee for "closed shop" preference. Whether Knox's takeover of Columbia's utility services had connections to Southern Power remains unclear, but his subsequent actions in Columbia and Spartanburg expose Knox's redoubled determination to completely destroy the streetcar union across the South Carolina Upcountry. ${ }^{8}$

The first inkling of trouble surfaced in the Trade Review, which reported: "Street Railway Employees Want Renewed Contract." No renewal of Division 590's exclusive contract had been forthcoming after its expiry on December 31, 1919. John B. Lawson, a special organizer for the Amalgamated Association, sought negotiations with the new company management, only to be rebuffed. Lawson soon discovered "company officials" had drawn up "yellow dog" contracts to break the streetcar union's influence. Furthermore, Knox turned away a local delegation from the Columbia Federation of Trades requesting a modest raise for the streetcar workers. However, Governor Robert A. Cooper and Senator Pearce both urged the new president of Columbia Railway to bargain with the unions. According to union spokesmen, a trolley strike was "by no means improbable." In a show of solidarity, car barn workers and electricians also went

Herald, edited by George McFarlane. (Trade Review of Columbia, 2 January 1920, 1; 2 April 1920, 1).

${ }^{8}$ Columbia Record, 28 January 1920, 1. 
on stand-by until an agreement could be reached. After nearly a month of patience, Division 590 finally staged a peaceful walk-out on 28 January $1920 .^{9}$

Predicting a long "tie-up," Columbia Record journalists initially sought to remain balanced in their interviews with strike principals. CRG\&E president Knox outlined his refusal to accept any new contract proposal retaining Section 15, stipulating a closed shop policy. Knox even agreed to the sought-for wage increases, if only streetcar workers omitted the union clause, which he claimed no longer applied in peacetime. Without a National War Labor Board to enforce original contracts, Knox reserved his right as CRG\&E's chief executive to nullify prior agreements made by his predecessor. ${ }^{10}$

Toward this end, Knox placed a full-page advertisement in the 29 January Columbia Record. Taking a page from Zebulon V. Taylor, Knox rhetorically asked: "Why Did the Men Quit Their Jobs?" He blamed their purported act of "bad faith" on questionable advice from their leaders. Claiming the "closed shop" provision had been a mistake, Knox cited possible abuses, should the union demand that the company collect their unpaid dues. As proof of his professed fairness toward labor unions, Knox upheld his willingness to grant the Electrician's Union a raise. ${ }^{11}$

To rebut Knox's arguments, Ambrose Gerald of Division 590 stressed to reporters that CRG\&E's closed shop guarantee had been observed for eight years by Edward Robertson. Gerald alleged that Knox only made an issue of union membership to "divert the public eye" from the real issue, Division 590's relatively low wage scale. With Columbia's recent fare increase from 5 to 7 cents, Gerald believed Knox could easily

\footnotetext{
${ }^{9}$ Trade Review of Columbia, 2 January 1920, 1; Motorman and Conductor. Vol. 28, No. 3 (February 1920), 12.

${ }^{10}$ Columbia Record, 28 January 1920, 1.

${ }^{11}$ Columbia Record, 29 January 1920, 1.
} 
afford a living wage for his men, especially since Columbia streetcar men were paid somewhat less than Knox's employees in the smaller town of Spartanburg. ${ }^{12}$

By the first week of February 1920, the transportation strike in South Carolina's capital city threatened to embroil both Governor Cooper and the South Carolina General Assembly. Headlines reported "No End in Sight for Car Strike," as Governor Cooper supervised two fruitless conferences between union representatives and company president Knox. South Carolina's road engineer, D.G. McAlister, acted as mediator, perhaps because Governor Cooper may have been too deeply involved. Under political pressure from the South Carolina House of Representatives, Governor Cooper soon referred the strike negotiators to the State Conciliation Board, helmed by two familiar figures with streetcar strike experience -- Benette E. Geer of Greenville, and H.E. "Smoke" Thompson of Batesburg. Geer and Thompson were joined by W.H. McNairy of Chester. Streetcar workers expressed their desire for hourly wages peaking at 54 cents, plus union recognition by CRG\&E. Knox offered 52 cents per hour in exchange for dropping the issue. Both sides refused to budge on the sticking point of recognition. ${ }^{13}$

How did the Columbia public respond to this episode? Fears of major railway strikes spiked, as major railroads reverted to private service at the end of February. Revealing their corporate biases, Columbia Record editors Charlton Wright and Walter Duncan openly accused the street railway men of making "ill-timed demands" and promoting "class interests" in their support for government control. When conservative anti-labor assemblymen proposed to ban the closed shop in South Carolina, the Columbia

12 Columbia Record, 28 January 1920, 1.

${ }^{13}$ Columbia Record, 1 February 1920, 2; 4 February 1920, 3; 13 February 1920, 4; Trade Review of Columbia, 27 February 1920, 1-2. 
Record upheld such legislation, stating that a given employer "should be free to follow his purpose without the intervention of the law." 14

In the final week of February 1920, the McDonald Anti-Closed Shop Bill went up for votes. This state proposal aimed to restrict collective bargaining and ban public labor demonstrations. Over two hundred workingmen were present during the session to demonstrate their solidarity. Most Upcountry representatives opposed this proposal. Only Congressman Gray of Spartanburg sided with the anti-labor delegates, who mounted an unsuccessful filibuster. Reporting from Columbia, C.H. Parks of the Trade Review hailed the McDonald Bill's defeat as South Carolina labor's "greatest victory."15

South Carolina's McDonald Bill coincided with similar anti-union proposals at every level. During 1919, no fewer than seventy sedition bills were introduced in Congress. C.H. Parks singled out the proposed Graham-Rice Sedition Bill in Trade Review, warning this legislation could imperil the national labor movement, as it called for censorship of all labor newspapers, with restrictions over the use of postal services. Striking workers could be tried on conspiracy charges, facing imprisonment for twenty years. Under this code, even landlords who privately rented to labor unions could be held liable. Given Columbia's well-established union leadership, the McDonald Anti-Closed Shop Bill, and its many federal counterparts, would have done great injury to the workingmen of South Carolina. ${ }^{16}$

${ }^{14}$ Columbia Record, 7 February 1920, 4; 10 February 1920, 1; 13 February 1920, 1.

${ }^{15}$ Trade Review of Columbia, 27 February 1920, 1-2; 12 March 1920, 1.

${ }^{16}$ In 1921, the Graham-Sterling Bill passed into the U.S. Senate as the more stringent Graham Peacetime Sedition Bill. However, this bill ultimately failed to become federal law. (Trade Review of Columbia, 27 February 1920, 1-2; 12 March 1920, 1; Eliot Asinof, 1919: America's Loss of Innocence (Donald Fine, Inc.: New York City, NY, 1990), 174-75). 
Meanwhile, the first Columbia streetcar strike entered its second week with little hope for resolution. With little fanfare and no newspaper coverage, Albert E. Jones arrived from Ohio. Now the AASERE's Eleventh Vice-President, Jones met with South Carolina's Conciliation Board to settle a dispute that threatened to eclipse Charlotte. On February 6, Jones garnered some company concessions for Ambrose Gerald's striking motormen. In exchange for Knox's 52-cent hourly wage offer, Columbia's Division 590 regretfully sacrificed their "closed shop" status. However, Gerald's streetcar crewmen retained their union recognition and bargaining rights with Columbia Railway. Significantly, this new contract for 1920 did not include Knox's signature. Witnessed by "Smoke" Thompson and Ambrose Gerald, CRG\&E General Manager V. S. Wright signed for the company president, who had other problems brewing. ${ }^{17}$

Division 590's strike coincided with similar disgruntlement for Spartanburg's Division 897. In April 1920, Columbia Trade Review reported further "car trouble" at South Carolina Light, Power, and Railway. Workers complained that, since the resolution of their strike in July 1919, one of their streetcars still operated on city streets with replacement crewmen. They also alleged President Knox had failed to abide by his earlier promise not to discriminate against union employees, resorting to discriminatory practices designed to force union members to quit their jobs. New recruits signed "yellow-dog" contracts with Spartanburg Power and Light, promising not to join the now-depleted ranks of Division 897. These actions mirror Knox's strategy in Columbia, where his new broom sought to sweep clean at CRG\&E. ${ }^{18}$

${ }^{17}$ Motorman and Conductor. Vol. 28, No. 3 (February 1920), 12; Vol. 28. No. 4 (April 1920), 11-12, 32-34.

${ }^{18}$ Trade Review of Columbia, 9 April 1920, 1-2; Fetters, 91. 
Offenses toward streetcar union members continued to accumulate. Spartanburg Division president H.E. Sitton requested a wage increase in late 1919. But Knox had refused to even look at a new 1920 contract proposal from union representatives. The contract mirrored the original bargain struck in 1919 by the Spartanburg arbitration process, except for a modest wage increase up to fifty cents per hour for the senior men. Knox's actions might be seen as cost-cutting measures, considering that SCLP\&R had steadily lost money since 1916. But the company president's pettiness knew no bounds. Knox also broke his July 1919 guarantee of monthly vacation days, leading T.A. Wilson of the Spartanburg Central Labor Union to sympathize with the strikers. He defined the "unrest fermenting in Spartanburg" as the results of a "plain case of discrimination" against the labor union that had caused Knox so much recent grief. ${ }^{19}$

H.E. Sitton appealed to South Carolina's Labor Department, whose representative, William C. Liller interceded unsuccessfully on behalf of the Spartanburg chapter. Columbia's Local 590 planned a rally on 15 April, to demonstrate support for their neighboring local union in distress. However, a second streetcar strike did not take place in Spartanburg. In forcing the streetcar union to knuckle under in Spartanburg, Knox may have taken some grim satisfaction for his previous defeat in 1919. If so, Knox did not savor his victory in Spartanburg for very long. South Carolina Light, Power and Railway owed several debts to various corporations, including $\$ 13,358$ to General Electric. During February 1921, Spartanburg's street railway system fell into state receivership. This development could not have pleased Zebulon Taylor, as Southern

\footnotetext{
${ }^{19}$ Trade Review of Columbia, 9 April 1920, 1-2.
} 
Public Utilities still owned stock in the Spartanburg-based utility enterprise. Knox, however, still retained control of Columbia Railway, Gas, and Electric Company. ${ }^{20}$

During the watchful year of 1921, Columbia Railway also began to lose revenues, as even fewer people rode the trolleys in Columbia. Inexorably, private automobiles and jitney buses had begun to eclipse the electric streetcar across the region. Transportation historian Thomas Fetters -- slightly biased toward the business side -- blamed CRG\&E's decline on town ordinances designed to keep one-man cars out of Columbia. Fetters also cited the company's recent fare hikes to seven cents (ten cents for transfers) as another factor. Yet, Franklin Knox's ensuing actions in early 1922 reveal his underlying motive to purge the local streetcar union. ${ }^{21}$

In January 1922, Knox submitted a new contract deemed unacceptable by the union, chiefly because its terms no longer guaranteed arbitration. Knox further cut his workers' pay scale by a full 10 percent, and announced his plan to introduce one-man cars. Division 590's president, Ambrose A. Gerald, told Columbia reporters that his men decided to "stomach wage reductions," but felt union arbitration rights were "inviolable." Gerald, recently elected to a third term as Richland County's representative, also served as the South Carolina House Chairman on Railroads. Gerald's platform also boasted a plan for textile mill reforms. While the South Carolina Senate defeated Gerald's proposal for eight-hour workdays, Gerald sponsored a successful bill enforcing statewide

${ }^{20}$ South Carolina Gas and Electric Company purchased South Carolina Light, Power, and Railway's assets for $\$ 1,000,000$ on July 31, 1922. After several years of sporadic streetcar service, Southern Public Utilities re-purchased the property in December 1928, and Spartanburg's streetcar services limped along until Duke Power phased out all its trolley systems in favor of motor-bus transportation lines in 1936. (Trade Review of Columbia, 9 April 1920, 1-2; Fetters, 91-94).

${ }^{21}$ Fetters, 46-47. 
maximums of 55 hours per week. He also authored the Discharged Laborers Act, requiring corporations to pay employees immediately upon dismissal. ${ }^{22}$ Holding a distinguished state office, as well as union leadership, A.A. Gerald proved a formidable adversary for Franklin Knox throughout the coming months.

After a tense month, with Knox refusing to renegotiate with Gerald's union, matters came to a serious head. On Valentine's Day of 1922, Knox discharged 21 streetcar men, citing his company's rising overhead. Nearly all these employees belonged to the Columbia streetcar union. On February 15, President Knox publicly aired his business concerns, explaining his street railway had deficits totaling $\$ 119,758.46$. Furthermore, CRG\&E’s state property taxes were unpaid as of February, raising the company's total debt to $\$ 209,758.46$. Knox argued that his decision to discharge its employees was solely based on January losses of $\$ 11,886.32 .{ }^{23}$

That same day, Ambrose Gerald led his workers on strike. Gerald accused Knox of seeking to destroy the Columbia streetcar union, claiming that his 21 discharged compatriots were all local members in good standing. Nearly all Columbia Railway's108 conductors and motormen belonged to Division 590, so Knox's mass firing reduced the union's strength by one-fifth. Gerald informed the AASERE General Executive Board that Knox displayed an "attitude threatening to dismiss more," with the "apparent purpose of destroying the organization." Undisputedly, President Knox of the Columbia Railway had taken a calculated risk in triggering this second streetcar strike in two years. Under Columbia city law, his company had 90 days to resume service or lose its

${ }^{22}$ Columbia Record, 15 February 1922, 1, 10; Motorman and Conductor, Vol. 30, No. 3 (February 1922), 13-14, 24; Vol. 30, No. 10 (September 1922), 8-9.

${ }^{23}$ Columbia Record, 15 February 1922, 1, 10; Fetters, 46-47. 
exclusive contract. Once more emulating actions of Zebulon V. Taylor, Knox purchased a full-page advertisement in the sympathetic Columbia Record to submit his case. Moreover, Knox decided to confront Gerald in the public forum. ${ }^{24}$

First, Knox replied to Gerald's imputations of hostility to unions, emphasizing his policy aimed to "give every man a square deal." However, the wily president refused to allow Gerald any leverage for argument. "Just what [constitutes] a square deal cannot be defined in any agreement, as it is a very broad term," Knox hedged. Then, Knox warned his striking workers, as well as the general public, that CRG\&E might soon "find it necessary to discontinue operations." On the subject of state arbitration, Knox felt his company "could not agree to submit to arbitration the question of whom we shall employ or discharge." Claiming his right to decide CRG\&E's best course, Knox instructed Ambrose Gerald and his supporters to "consider the position of this company final." In the company president's view, the 108 strikers brought the resulting lockout on themselves. Knox washed his hands of all blame. ${ }^{25}$

Within a few days, A.A. Gerald made a press statement, albeit without front-page coverage. In Gerald's estimation, Knox may have desired to cut costs, but felt his union compatriots had been unjustly fired "without a clear purpose." Gerald suggested the reduction of older streetcars in CRG\&E's service might cut operation costs. Gerald reassured Columbians that his union did not seek to control the company through closed shop doctrines. As a state legislator, Gerald believed state laws providing for worker arbitration would justify their cause. He proposed an arbitration plan, wherein labor and

${ }^{24}$ Columbia Record, 15 February 1922, 1, 10; Motorman and Conductor, Vol. 30, No. 3 (February 1922), 13-14.

${ }^{25}$ Columbia Record, 15 February 1922, 1, 10. 
capital each would have one representative. Since Division 590 and Knox would likely not agree on a mediator, Gerald suggested the Columbia mayor, R. Johnson Blalock. ${ }^{26}$

Mayor Blalock held a town meeting during the strike's first week, endorsing the arbitration process. However, the mayor could not compel Knox to cooperate with the State Board of Conciliation. Moreover, as Columbia served as the state capital, Blalock most likely deferred this serious labor matter to Robert A. Cooper, still in office as a lame-duck governor. Throughout the month of February, both the mayor and governor kept their own counsel, coordinating with the State Board of Conciliation. Meanwhile, John B. Lawson from the Amalgamated Association's General Executive Board came to assist the local union. ${ }^{27}$

Columbia Record editors predicted the city's streetcars would remain "idle for many days," observing the city's "traveling public" used streetcars less frequently. However, there were still "many who depend on street railways." Though streetcar tracks were "covered with rust," the strike at least kept the company "out of more losses." 28 Meanwhile, Ambrose Gerald, true to his word, went to the state legislature with his special arbitration proposal, which quickly passed both houses of South Carolina's General Assembly. This narrowly-stipulated legislation applied specifically to Columbia, requiring CRG\&E's management to fully explain its firing of employees. Moreover, it re-affirmed the city's 1917 wartime measure, requiring streetcars to run with experienced crewmen, or substitutes with two weeks of training under such motormen. Violators

\footnotetext{
${ }^{26}$ Columbia Record, 16 February 1922, 1; 17 February 1922, 1; 18 February 1922, 1; 19 February 1922, 1, 3.

${ }^{27}$ Columbia Record, 17 February 1922, 1; 18 February 1922, 1; 19 February 1922, 3.

${ }^{28}$ Columbia Record, 16 February 1922 , 1; 20 February 1922, 7.
} 
could face maximum fines of $\$ 100$ or jail sentences of up to one month for each day of operation. Such measures were designed to prevent Knox from hiring strikebreakers. ${ }^{29}$

By February 22, Governor Cooper had signed the Gerald Arbitration Act into law, naming Former Richland County Sheriff John McCain as the mediator. However, Columbia Railway attorney J. B. Lyles questioned the constitutionality of Gerald's measure, especially the clause re-affirming the streetcar regulations. When the State Attorney General's office indicated the existing ordinance was indeed constitutional, J. B. Lyles promised to challenge the state's ruling in the South Carolina Appeals Court. ${ }^{30}$

On February 27, Lyles went before Associate Justice T.P. Cothran to secure an injunction against lower courts and labor representatives to prevent them from enacting either the Gerald Act or the 1917 statute. Invoking that well-used ploy of businessmen, the 14th Amendment, Lyles claimed the Gerald Act hurt his company's profits because it prevented them from hiring new motormen. He also alleged that no other utility company in South Carolina had to deal with such discriminatory regulations. ${ }^{31}$

As Justice Cothran weighed the Gerald Arbitration Act's legality, CRG\&E president Knox appealed once more to public opinion, demanding the right to select his company's own motormen and conductors, specifying their work conditions, and reserving the power to discharge them without arbitration. Knox certainly had supporters among the business community of Columbia. Charlton Wright and Walter Duncan editorialized in the Columbia Record after the strike's second week had passed. Addressing the "Car Strike," Wright and Duncan summarily dismissed the local streetcar

${ }^{29}$ Columbia Record, 22 February 1922, 10; 24 February 1922, 1; 25 February 1922, 1.

${ }^{30}$ Columbia Record, 22 February 1922, 10; 27 February 1922, 5, 10.

${ }^{31}$ Columbia Record, 22 February 1922, 10; 24 February 1922, 1; 25 February 1922, 1; 27 February 1922, 5, 10; 28 February 1922, 1. 
union, a respected part of Columbia's labor movement for ten years, as a mere organization "banded together for their private purposes... without the least responsibility towards the public." The editors also considered the 1917 ordinance too powerful for the likes of such an "unimportant group to bludgeon the company into submission." While claiming to support only the public's interest, Columbia Record's editors openly sided with the company's desire for "some freedom of action." 32

By the end of February, the Columbia streetcar strike of 1922 developed into a stalemate. William A. Coleman told reporters that the City Council alone could not bring a ready solution, although its members continued to work as private citizens to bring an end to the impasse. City Council members proposed to refer the strike to the state courts, which agreed to review the case on March 7. In the meantime, South Carolina representatives adopted their own measure to investigate Knox's claims of financial hardship. Under W.D. Barnett's resolution, state tax commissioners would investigate Columbia Gas, Railway, and Electric's tax claims. Barnett's resolution passed amid doubts whether it would affect the state's forthcoming judicial review. ${ }^{33}$

Meanwhile, the city of Columbia dealt with the transportation shortage through means of a legitimate jitney service. On March 1, the Chamber of Commerce approved two local organizations of volunteer drivers, calling themselves the "Jump in and Ride" and "Ride with Me" movements. William Lykes served as city transportation chairman, funding signs and placards to inform suburbanites of the city's assembly points.

Needless to say, "Jump in and Ride" and "Ride with Me" programs were well-received

${ }^{32}$ Columbia Record, 27 February 1922, 5, 10; 1 March 1922, 4-5.

${ }^{33}$ William Coleman shortly thereafter succeeded R. J. Blalock as mayor of Columbia. (Columbia Record, 28 February 1922, 1, 10; 1 March 1922, 1). 
by auto owners, because participation allowed them to make spare change. Several hundred townsfolk assisted in this initiative to relieve the streetcar strike during the rainy season. Coincidentally, state lawmakers took a courtesy ride on a newly paved Richland County road on March 3, promoting a budget for improved South Carolina roads. ${ }^{34}$ Division 590 seems to have tolerated these voluntary driving programs, if only because they discouraged would-be passengers from riding non-union streetcars. Whereas streetcar unions often saw jitneys as unfair competition under normal circumstances, such measures could prove beneficial during a strike. Such had been the case in Charlotte almost three years earlier. For now, the Columbia streetcar union concentrated on the March 7 court proceedings, which would determine the final authority over the streetcar situation. On the night prior to their court date, John Lawson and A.A. Gerald rallied their supporters at the courthouse. Censuring the Columbia Railway's obduracy, Gerald nevertheless promised his men would "go to work in the morning" if their company offered contracts similar to Charleston's recent agreement, guaranteeing overtime benefits and city arbitration, among other rights. ${ }^{35}$

Columbia Record thereafter dismissed the union's courthouse demonstration as "staged gestures," because its audience consisted solely of union members, or those with political grudges against the Columbia Railway, Gas, and Electric Company. "Public utilities in Columbia have long been the football of small politicians and small candidates," the editorial opined, taking a subtle swipe at Ambrose Gerald's political

${ }^{34}$ Columbia Record, 2 March 1922, 10; 3 March 1922, 2.

${ }^{35}$ Columbia Record, 7 March 1922, 10; Motorman and Conductor, Vol. 30, No. 4 (February 1922), 36-37. 
career. Columbia Record openly sided with "vitally interested" businessmen who "work for a living," with implications that Gerald and his supporters were not industrious. ${ }^{36}$

After a week's deliberation, the Columbia court ruled on the strike. As state capital, Columbia's street railway system came under "direct scrutiny" of the South Carolina Board of Railroad Commissioners. This governmental body had just been expanded by the state legislature from three to seven panelists. Immediately, the Railroad Commission ordered Columbia Railway to get their streetcar lines running within one week, or they would assume control. Franklin Knox now faced a serious deadline, complicated by the fact Augusta, Georgia's streetcar lines commenced with a strike of their own. ${ }^{37}$

Shortly after the court's ultimatum, Knox delivered one of his own: Columbia Railway streetcar men had until noon, March 17, to cross the picket line, or risk being replaced by new workers. Knox promised nine-hour shifts, recognizing seniority wherever possible, but claimed the right to dismiss employees without union arbitration. A.A. Gerald read the company's proffered contract, and promptly rejected Knox's demands, on grounds that his terms would return Division 590 workers to the exact obligations they had endured prior to the strike. ${ }^{38}$

However, Knox's appeals met with some success. Some prior streetcar crewmen defected from the union, while others applied for vacant positions. Columbia Railway

${ }^{36}$ Columbia Record, 10 March 1922, 4.

37 J.B. Lawson briefly left Columbia to resolve Division 577's grievances, stemming from jitney competition. Within one month, Augusta's streetcars had returned to service. (Columbia Record, 15 March 1922, 1; 16 March 1922, 1; Motorman and Conductor, Vol. 30, No. 4 (March 1922), 13-14; Fetters, 47).

${ }^{38}$ Columbia Record, 16 March 1922, 1-2; Motorman and Conductor, Vol. 30, No. 4 (March 1922), 13-15. 
Superintendent J.W. Spence later told reporters that 35 men in total had answered CRG\&E's first calls for employment. Some recruits came from Georgia, North Carolina, and Virginia. With a small workforce prepared to resume car service within the week, Knox felt confident enough to decline Gerald's contract proposal, under supervision of the state Railroad Commission. While Governor Cooper had expanded the commission's powers to act in the public interest, it lacked the power to compel Knox into City Hall. ${ }^{39}$ Columbia's city councilors, in the meantime, agreed that South Carolina's Railroad Commission, with its broad authority, obviated the need for the city's wartime ordinance restricting streetcar crewmen from operating cars without training. This decision dashed Gerald's hopes of testing the 1917 law against Knox's new employees. This sent a clear sign to Division 590 that their days in Columbia were numbered. ${ }^{40}$

On March 20, Columbia Railway activated three streetcars for limited service in downtown Columbia. That afternoon, one of Knox's streetcars passed the Union Hall on the 1500 block of Main Street. Two crewmen were allegedly dragged from their posts by a small crowd. Police could find no injured parties on Main Street, but discovered broken windows toward the streetcar's rear. One operator, Brooks, later claimed to have been blackjacked. Three men were arrested. Meanwhile, a second report brought two carloads of policemen to Colonial Heights, where a crewman and one passenger had been taken to Columbia Hospital for treatment. ${ }^{41}$

Mayor Blalock and the city magistrates heard both cases on the next day.

Conductor H.T. Shannon accused three defendants, J.L. Jennings, D.K. Spiers, and S.P.

${ }^{39}$ Columbia Record, 17 March 1922, 1, 7; 22 March 1922, 1.

${ }^{40}$ Columbia Record, 20 March 1922, 1.

${ }^{41}$ Columbia Record, 20 March 1922, 1; Fetters, 47. 
Snelgrove, of participation in the Main Street incident. However, owing to a lack of corroborative witnesses, Jennings, Spiers, and Snelgrove were released on peace bonds, free to go as long as no further problems arose. In the meantime, Columbia police had apprehended two men in connection with the Colonial Heights incident. B.S. Ward, J.O. Williams, and three others were seen following the Colonial Heights streetcar in an automobile prior to the assault. Ward and Williams were both charged with multiple counts of assault and battery, while the other suspects were held on lesser charges. ${ }^{42}$ Indubitably, such incidents significantly damaged the union's standing in Columbia. Columbia Railway took their cars off-line to prevent further damage, and Knox appealed to Governor Robert Cooper for protection. Cooper vowed to protect the streetcar service, even promising to deploy the National Guard if necessary. His justification for such a drastic step hinged upon the company's compliance under the state Railroad Commission. Meanwhile, the city of Columbia charged the men of Division 590 to refrain from further hostility. Gerald pledged to exert discipline among his ranks, even as Columbia Railway's streetcars resumed service on March $22 .{ }^{43}$

Throughout the tense days of late March, Gerald persisted in seeking lawful means to end the company lock-out. On March 23, Associate State Justice Cothran finally upheld the Gerald Act's provisions for state arbitration. However, CRG\&E's attorney, J.B. Lyles, insisted his company did not require arbitration, as it had already complied with the state Railroad Commission's order to resume street railway services. Moreover, Lyles argued that Judge Cothran's ruling could not alter the company's ongoing process of employing and training new workers. Unfortunately for Division

\footnotetext{
${ }^{42}$ Columbia Record, 21 March 1922, 1; Fetters, 47.

${ }^{43}$ Columbia Record, 21 March 1922, 10; 22 March 1922, 1; Fetters, 47.
} 
590, Lyles had built a persuasive case against the 1917 law. Under its wartime provisions, new streetcar workers were required to train for fifteen days under experienced motormen. Since some veteran workers had already crossed the picket line, Knox's strikebreakers now had qualified trainers. But the question now remained whether these new men were trained for the requisite period before assuming duty. ${ }^{44}$

This legal point quickly became moot. Ambrose Gerald brought his test case to the Richland County courthouse, where County Judge C.J. Kimball dismissed the streetcar union's case against T.C. Chalker, a replacement motorman accused of violating the wartime code. In rebuttal, Chalker testified to several years of streetcar experience in Jacksonville, North Carolina, corroborated by CRG\&E superintendent J.W. Spence. ${ }^{45}$

Furthermore, Kimball sided with Columbia's city councilors, believing the state Railroad Commission overrode city law, effectively repealing the wartime condition on street railways. One might question whether due legal process had actually repealed the ordinance in question, or if these decisions simply reflected widespread opposition toward the law's original intent - to protect Division 590 from downsizing and strikebreakers. Gerald promised to appeal Kimball's ruling to higher courts. Shortly after Kimball's decision, the union representatives appealed to the District Court to name a state arbiter who would force Franklin Knox to listen to grievances. Knox, however, maintained that arbitration would put his company out of business. ${ }^{46}$

By Monday, March 26, ten Columbia Railway streetcars were running under police guards, with an eleventh car joining them on the next day. By March 29, twelve

\footnotetext{
${ }^{44}$ Columbia Record, 23 March 1922, 1, 7; Fetters, 47.

${ }^{45}$ Columbia Record, 24 March 1922, 1, 7, Fetters, 49.

${ }^{46}$ Columbia Record, 25 March 1922, 10; 26 March 1922, 1.
} 
streetcars plied their routes across Columbia. That week, Mayor Blalock ordered six policemen to convoy each streetcar, with five officers in automobiles and one astride a motorcycle. Rural police and sheriff's departments were to escort streetcars over CRG\&E's three suburban lines. Citing public safety, Blalock asserted his regard for the streetcar union, refusing to blame Gerald's men for the recent violence. Blalock blamed "other elements" for taking advantage of the Columbia strike to commit crimes. ${ }^{47}$

Only one arrest took place under these vigilant circumstances, which lasted until March 30. Will Etters, rumored to have been involved in the Colonial Heights incident, openly criticized police escorting the streetcars. More serious charges awaited J.O. Ward and B.S. Williams, the two men charged with leading the Colonial Heights attack on March 20. Already booked on charges of assault and battery, with murderous intent, these two men also faced possible federal prosecution, as two Columbia streetcars had been carrying U.S. mail on the date in question. ${ }^{48}$

Even after Mayor Blalock's removal of police escorts on March 30, some officers were kept on station at suburban lines to deter vandals. Franklin Knox welcomed the normalization, even going so far as to accept A.A. Gerald's word that his union chapter did not authorize the violence on March 20. But Knox's magnanimity had its limits. Even as he reassured Gerald that his policy did not mean a war against organized labor, the general manager of Columbia Railway still refused to meet with state arbitrators. ${ }^{49}$

With the Columbia street railway system in full service under replacement labor, South Carolina's capital city went back to normal. But the streetcar union held on until

\footnotetext{
${ }^{47}$ Columbia Record, 27 March 1922, 1; 28 March 1922, 10; 29 March 1922, 1;

${ }^{48}$ Columbia Record, 29 March 1922, 1; Fetters, 49.

${ }^{49}$ Columbia Record, 30 March 1922, 1.
} 
the bitter end. J.B. Lawson kept in contact with A.A. Gerald and his loyal band of streetcar workers. Throughout the remaining months of 1922, union correspondents informed Motorman and Conductor that CRG\&E operated its streetcars at a loss. Low patronage had taken its toll on the company, even while strikebreakers received full pay. Meanwhile, some of the streetcar workers began operating "auto-buses" to "care for the people." Such tactics were also practiced in Richmond, Virginia, where another lock-out had endangered two AASERE chapters since January 1922. In Columbia, independent jitneys now competed with the streetcars their drivers had once operated with pride and purpose. Transportation historian Thomas Fetters confirms that these buses had a palpable effect on CRG\&E's economic decline over the next few years. ${ }^{50}$

By June 1922, Division 590 recognized their fight with Knox as being "one to the finish.” At James B. Lawson's urging, the AASERE General Executive Board granted Division 590 full relief from its membership dues as they struggled for survival. Columbia Railway increased its operational cars to twenty-two vehicles by July. Division 590's correspondent also noted the company's losses had continued to deepen, owing to decreased patronage. Union men attributed low patronage to popular opposition toward "scabs." Such men, in the words of one union member writing to Motorman and Conductor, were "undermining the shaft that will fall upon their own heads." ${ }^{51}$

By November 1922, most of the Division 590 members had sought other professions, or became bus drivers in competition with their former company. Rumors

\footnotetext{
${ }^{50}$ Motorman and Conductor, Vol. 30, No. 5 (April 1922), 1; Vol. 30, No. 6 (May 1922), 12-13; Vol. 30, No. 7, (June 1922), 15; Fetters, 49.

${ }^{51}$ Motorman and Conductor, Vol. 30, No. 7, (June 1922), 15; Vol. 30, No. 8, (July 1922), 15; Vol. 30, No. 9 (August 1922), 15; Vol. 30, No. 11 (October 1922), 14-15, 25, 31; Vol. 30, No. 12 (November 1922), 12.
} 
circulated that Columbia Railway, Gas, and Electric Company teetered on the edge of receivership under Stone \& Webster that fall. However, the union members reported the same "self-seeking" company management remained in charge of Columbia Railway that December. Following the holidays, fortunes did not improve for A.A. Gerald's union chapter. Motorman and Conductor's last contact with Division 590, April 1923, stated "it is problematical as to how long this condition will survive."

Knox's successful strategy against the streetcar union yielded a pyrrhic victory at best. In this goal, Knox had the willing aid of many influential state and local authorities, which outmaneuvered the forces of labor in the courts and public opinion. But Thomas Fetters indicates Columbia's defeat of unionism did not solve CRG\&E's problems. Operating streetcars at a loss, competition from former personnel, and rising passenger fares all took their toll on the Columbia utility corporation. But Fetters also brought up another major catalyst in streetcar decline, borne out by the newspapers of the era. Even while the streetcar strike had been but a month old, Columbia townsfolk were already preparing for the second of three Palmetto State Festivals, known colloquially as Palmafesta. Sponsored by South Carolina's Chamber of Commerce, these auto festivals encouraged local dealerships and promoted state roads. ${ }^{53}$

Columbia Railway, Gas, and Electric Company declined after the strike. In 1922, South Carolina tried to seize an unfinished canal from CRG\&E, citing the state's original possession of the property. Since 1917 , the utility company had failed to complete a

\footnotetext{
${ }^{52}$ Motorman and Conductor, Vol. 30, No. 12 (November 1922), 12, 24; Vol. 31, No. 1 (December 1922), 12-13; Vol. 31, No. 2 (January 1923), 14-15; Vol. 31, No. 3 (February 1923), 13; Vol. 31, No. 4 (March 1923), 13; Vol. 31, No. 5 (April 1923), 13.

${ }^{53}$ Columbia Record, 15 March 1922, 1; John Hammond Moore, Columbia and Richland County (University of South Carolina: Columbia, South Carolina, 1993), 333; Fetters, 49.
} 
hydro-electric dam, yielding 500 horsepower to the city of Columbia. Expensive lawsuits and countersuits accumulated, until the U.S. Supreme Court upheld the company's property rights in January 1923. By 1925, Franklin Knox had been replaced by F. K. Woodring. Patronage on Columbia Railway trolleys had fallen quite dramatically, a onethird reduction from the previous year's figures. Columbia's Chamber of Commerce, likely noting the success of competing motor-buses on the city streets, suggested CRG\&E should replace their trolleys. Columbia Railway ceased to exist in 1934. Columbia, however, retained a few electric streetcars for interurban lines until they were retired in 1936. That same January, Franklin H. Knox passed away at age $71 .^{54}$

With the proliferation of automobiles, as well as Columbia's lobby for better roads, public opinion ultimately found the streetcar union question of marginal relevance. Despite operating at a loss, Columbia Railway, Gas, and Electric still managed to starve the local streetcar union out of existence. Ambrose Gerald had built a successful local streetcar union, lasting barely a decade. Like those of Charlotte, Winston-Salem, Greenville, and Spartanburg, Columbia's streetcar men were victims of the "open-shop" movement, later known as the "American Plan." But, unlike Zebulon V. Taylor, Franklin H. Knox had won his personal war against industrial democracy. Although his campaign to break AASERE Division 590 proved a Pyrrhic victory, Knox emerged victorious without firing a single shot.

${ }^{54}$ Franklin Knox died on January 16, 1936, and was interred in Spartanburg County. (Columbia Railway, Gas \& Electric Co. v. State of South Carolina, U.S. Supreme Court, 261 U.S. 236 (1923); South Carolina Genealogical Society, Pinckney Chapter, South Carolina Cemetery Survey, Spartanburg County, Volume 3 (Magnolia Church of the Advent: Oakwood, South Carolina, undated), 261; Fetters, 49-50). 


\section{Chapter Eight: Epilogue and Conclusions}

Wheels of progress ground across the Piedmont's millstone, even as the streetcar strikes of Spartanburg, Charlotte, and Columbia receded into unhappy memory, and then, near-obscurity. While the previous chapter addressed the fate of Franklin Knox's enterprises in South Carolina, this chapter will summarize the successful evolution of Southern Public Utilities into Duke Power, focusing upon its transition from electric street railways to bus lines. Furthermore, principal figures involved in the Carolina Piedmont streetcar strikes will receive final analysis.

Streetcar labor organization in the Carolina Piedmont withered on the vine after the events of 1919-22. Neither Columbia's nor Spartanburg's unions survived Franklin Knox's waiting game. Motorization soon obviated the demand, if not the need, for trolley systems in South Carolina's major towns. By the mid-1920s, Charleston remained the only South Carolina town with unionized street railways. In North Carolina, Charlotte's union had disbanded in the spring of 1922, while embryonic organizations in Salisbury and Durham, North Carolina (Divisions 920 and 923) also came to naught. Winston-Salem's movement lingered on for a brief time, but soon, Division 893 followed Charlotte's union into oblivion. Both Asheville and the coast city of Wilmington experienced strikes that jeopardized their streetcar unions, but in both cases, new contracts preserved old agreements. By 1925, Asheville Division 128 sent the Western Carolinas' sole union delegate, William B. Plemmons, to the AASERE's annual 
convention. Between Asheville, Wilmington, and Charleston, no signs of the streetcar union remained in the Carolina heartlands throughout the next two decades. ${ }^{1}$

Southern Public Utilities quickly regained its economic momentum after the Charlotte strike. Company sources estimated over $\$ 100,000$ in lost revenues and property damage, plus at least $\$ 400,000$ in lost business. Returning streetcar men were said to have lost $\$ 40,000$ in wages and expenses. John Paul Lucas of the Southern Public Utilities Magazine speculated the total loss approached "three-quarters of a million dollars," with some estimates closer to a full million. "Crippled companies do not expand and provide work... and service for more people," Lucas observed. Yet, Southern Public Utilities - and Southern Power - were far from crippled. By 1922, James B. Duke had built ten hydroelectric and four steam plants, providing 93 percent of the Carolina Piedmont's utility needs. Seventy-five percent went to textile mills, while 15 percent went to manufacturing and agricultural interests. The remaining thirteen percent went to towns and select households - Duke was much slower to embrace rural electrification. $^{2}$

Duke's growth accelerated the modernization of North and South Carolina's Piedmont regions, but it also alarmed other businessmen, as well as the governments. Even while the Charlotte Regional Strike took place, the Salisbury \& Spencer Railway Company built an anti-monopoly case against Southern Power, which went to the North Carolina Supreme Court in December 1919. Later in 1920, James B. Duke and Zebulon

\footnotetext{
${ }^{1}$ Motorman and Conductor, Vol. 27, No. 10 (September 1919), 11; Vol. 30, No. 1 (December 1921), 32-33; Vol. 31, No. 4 (March 1922), 8; Vol. 33, No. 3 (February 1925), 14; Vol. 33. No. 11 (October 1925), 10.

${ }^{2}$ Southern Public Utilities Magazine, Vol. 5, No. 4, (15 September 1919), 1-4, 16; Tullos, 163-64.
} 
Taylor also faced state hearings before the North Carolina Corporation Commission.

Since 1913, state Democrats had sought to limit Southern Power's utility rates. In 1920, the Corporation Commission in Raleigh sponsored a rate-control bill. Duke listened from the gallery as Zebulon Taylor and William States Lee argued on the corporation's behalf. One should note Duke's rare personal appearance. Herman Wolf, an engineer employed by Southern Power at that point, later recalled that Duke did not "take kindly to interference with his electric rates." Despite strong popular support, North Carolina's regulatory measure failed to pass General Assembly by a single vote in March $1921{ }^{3}$

Soon after his victory, Zebulon V. Taylor passed away on 18 April 1921. Taylor's death occurred en route to New York aboard James B. Duke's personal train. Taylor's official cause of death appears to have been "acute indigestion," but the company president had also lost his wife and suffered from appendicitis in 1920. Others speculated Taylor's personal exertions during Southern Power's "Rate War" may have also taken their toll. In Habits of Industry, Allen Tullos described a similar fate for D.A. Tompkins in 1914, because "strenuous" devotion to his North Carolina business empire left little room for "exercise and recreation." It would seem both Tompkins and Taylor had fallen prey to their own Protestant work ethic, taken to its most extreme conclusions. Numerous tributes poured out to Taylor from regional newspapers, as company treasurer E.C. Marshall quickly assumed control of Southern Public Utilities. ${ }^{4}$

\footnotetext{
${ }^{3}$ Henry C. Spurr, Public Utilities Reports Annotated (Rochester, New York: Public Utilities Reports, Inc., 1920), 688-713. Charlotte News, 1 August 1920, 3; Durden, 160-163; Wolf interview.

${ }^{4}$ Southern Public Utilities Magazine, (Vol. 6, Nos. 11-12), April-May 1921, 1-11; Irving Scales-Taylor, death certificate, November 18, 1920, North Carolina State Board of Health; Turner; Coleman and Humphreys; Randolph County Courier Tribune, 21
} 
James B. Duke's legacy has been well-documented by Robert Durden and other historians. In December 1924, Duke set aside $\$ 40$ million for the Duke Endowment, funding several colleges across the Carolinas. One-third went to Trinity College in Durham, North Carolina, renamed Duke University in its benefactor's honor. Two Charlotte colleges also benefited from Duke's generosity; the traditionally black Johnson C. Smith University and the Presbyterian Davidson College. Duke's friend and trustee, Ben E. Geer, also received support for Furman College in Greenville, South Carolina. Yet, James B. Duke did not live long enough to see his vast endowment come to fruition. In the fall of 1925, the entrepreneur developed pneumonia, dying in his New York City mansion on October 10, at age $68 .^{5}$

In 1927, Southern Power changed its name to reflect its creator, a man who undoubtedly fulfilled the New South ideal, whether or not he believed in it. That year, Southern Public Utilities continued to appropriate streetcar lines, gaining 30 cars and 19 track miles in Greensboro and High Point. Duke Power retained Southern Public Utilities until its absorption in 1935. Duke Power went on to become the most significant utility company in the South, a leader of the so-called "Piedmont Carolinas Movement," a consortium of industrialists and "go-getters" who followed in James B. Duke's wake. Low wages continued to prevail through the region, although Duke Power did not lay off

April 1921, available from http://www.asheboro.com/ons/obits/1920-1929(S-T).html; Internet; accessed 22 April 2003.

${ }^{5}$ Benjamin Duke, who encouraged his younger brother to accelerate his endowment program before time ran out, died on January 8, 1929. (Durden, 153-92; Tullos, 164-66) 
its workers during the Great Depression. Herman Wolf recalled how Southern Public Utilities and its parent company "stuck together like a family" during the ongoing crisis. ${ }^{6}$

Transportation historian Walter Turner indicated that even during the 1920s, the North Carolina Corporation Commission had been discouraging toward electric streetcars. Competition with modern highways, auto-bus traffic, and a three-fold growth in car ownership, plus the costs of road maintenance, had rendered streetcars an endangered species. Smaller towns, such as Concord and Goldsboro, adopted buses just before the Great Depression. Other towns made the transition more slowly. Asheville, Raleigh, and Greensboro each reported high levels of ridership until the late 1920s. But, when these cities ended their street railway franchises in 1934, others began to follow suit. High Point and Winston-Salem ended streetcar service in 1935 and 1936. Trolleys remained one of Wilmington's popular beachside attractions, but in 1939, their bells clanged for the last time. ${ }^{7}$

On 15 November 1937, the North Carolina Utility Commission approved Duke Power's proposal to replace its aging streetcar lines with bus service throughout the company's sphere of influence. Over the years, Southern Public Utilities had experimented with trackless trolleys and motor-buses. Finally, the company settled on motorized buses, because they were perceived as "nearly noiseless" and more flexible than street railways. With 15 buses already in service, Duke Power estimated 45 more vehicles would be required over a six-month period. Within one year, most of the old

\footnotetext{
${ }^{6}$ Duke Power's consolidation of Southern Public Utilities in 1935 may have been a measure to absorb the debts accumulated from its failing street railway systems. (Durden, 136; Tullos, 166-70; Wolf interview; Coleman and Humphreys).

${ }^{7}$ Walter Turner, "Development of Streetcar Systems in North Carolina," available from www.cmhpf.org. Internet, accessed 24 August 2006.
} 
streetcar terminals were remodeled and modernized for Duke's bus-lines. Although "dime taxis" still competed for passengers in 1938, the new Charlotte bus system now served approximately fifty percent more citizens than had the street railway system. Duke's highly publicized bus campaign, with comfortable seats (in comparison with streetcars at least) and well-appointed bus terminals, met with public approval throughout the Carolina Piedmont. ${ }^{8}$

Over the course of several decades, Duke Power (now Duke Energy) engineers followed the traditions of William States Lee and Herman Wolf, providing electricity for residential districts and corporate sectors. Today, Charlotte has become a metropolis, dominating much of South Carolina's Upcountry, despite state boundaries. Parallel developments in Arkansas have allowed Bentonville to dominate the Ozarks. Bethany Moreton's To Serve God and Wal-Mart examines the evolution of Sam Walton's business empire, which not unlike Southern Power derived its original work-force from rural people steeped in Protestant work ethic, patriotic virtues, and hostility toward organized labor. Even in the midst of the Great Recession, Wal-Mart has proven resistant to labor reform, and consistently purges union sympathizers from its outlets. ${ }^{9}$

To borrow an apt political adjective, entrepreneurs such as Zebulon Taylor and Franklin Knox were “irreconcilables” toward organized labor. They usually employed lawful means to exert their will, but were capable of legal chicanery to outmaneuver unions. To these civilizers of the Piedmont, organized labor represented a barbaric "foreign" power seeking to stir up their otherwise content employees with false promises.

\footnotetext{
${ }^{8}$ Duke Power Magazine, Vol. 22, No. 5, (November 1937), 1-2.

${ }^{9}$ Thomas T. Fetters, Palmetto Traction (Forty Fort, PA: Harold E. Cox, 1978), 46-9; Bethany Moreton, To Serve God and Wal-Mart (Cambridge, Massachusetts: Harvard University Press, 2009), 103-4.
} 
While this work duly acknowledges James Duke's philanthropy, Southern Power's language belies the benevolent image constructed by Robert Durden and others. Zebulon Taylor, in particular, comes across as paternalistic toward workers and yet inflammatory toward labor reformers, who were consistently - some would say unjustly -- portrayed as "aliens" or "outsiders." But Duke and Taylor were not unusual cases of corporate paternalism, nor were they the worst. Historian Allen Tullos describes the role of conservative Protestantism in determining the long "stretch-outs" and "speed-ups" for textile mill hands and streetcar workers. Enlightened fathers of Piedmont industry knew best what their employees needed: more work. Free time, some employers argued, would permit black and white workers more opportunity for the Devil's work. Some probably viewed joining a labor union in one's spare time an even worse sin than rampant alcoholism. After all, labor organizers were portrayed as urban liberals wishing to force their alien views on the pure, American South. Whipping up prejudices, New South industrialists effectively blocked workers from unionizing. ${ }^{10}$

The events detailed in Between the Wheels also wrought significant changes on regional North and South Carolina politics. Mayor Frank R. McNinch became one casualty of the 1919 strike, at least in the short term. One of McNinch's Charlotte rivals, F.M. Shannonhouse, characterized Charlotte's 1919 recall election as a public condemnation for the progressive mayor's initial reluctance to use force against the "rapidly growing spirit of Bolshevism." For his part, McNinch regretted the violent outcome, and he seemed to quickly lose enthusiasm for Charlotte politics. On a rainy August evening one year after the strike, he addressed the State Federation of Labor at a

\footnotetext{
${ }^{10}$ Tullos, 134-71.
} 
local high school. The mayor felt Charlotte had "misinterpreted and misjudged" organized labor's motives during a period of high passions. McNinch voiced his philosophical opposition to "class government," whether by powerful industrialists or labor agitators. Instead, he exhorted Charlotte's workingmen to use "constructive... lawful methods" to effect positive changes, avoiding the influence of "gold-diggers" with "selfish purposes." Shortly after this revealing speech, Frank R. McNinch resigned as Charlotte's mayor to accept a regional position with the National Recreation Association of America, the forerunner of our present-day National Recreation and Parks Association. In this capacity, McNinch spent nearly a decade in the political wilderness. ${ }^{11}$

Over the ensuing two decades, Frank McNinch's later career reflected the difficult path of Southern Progressivism. In 1928, McNinch styled himself an "independent Democrat," convincing many North Carolinians to reject Alfred Smith, a Catholic who opposed Prohibition. Frank McNinch also stumped in favor of the conservative National Origins Act of 1924, invoking the wrath of W. J. Cash, managing editor of the Cleveland Press in Shelby, North Carolina. Deriding the concept of "Nordic Superiority," Cash also accused McNinch of extending the nation's "anti-Catholic pogrom" for his own political ambitions. ${ }^{12}$

${ }^{11}$ F.M. Shannonhouse, "How the Recall Worked in Charlotte," from the National Municipal Review, Vol. 9, No. 1 (January 1920); Thames Ross Williamson, Readings in American Democracy (Boston: D.C. Heath and Company, 1922), 512-14; Charlotte Observer, 9 August 1920, 1.

${ }^{12}$ Cash argued for a principled immigration control, instead of a selectively discriminatory policy. W.J. Cash might well be Wilbur J. Cash, author of The Mind of the South. Cleveland County, North Carolina, is a western Piedmont county adjacent to Mecklenburg. (William S. Powell, editor, Dictionary of North Carolina Biography, Vol. 4 (Chapel Hill \& London: University of Chapel Hill Press, 1991), 184-85; Cleveland Press. 28 September 1928, 4). 
Like the arch-conservative North Carolina Senator Furnifold M. Simmons, Frank McNinch defected to the "Hoovercrats," reaping great political rewards. Under the Federal Power Commission's statute, Hoover had to name one member from the opposition party, so McNinch seemed a safe bet. In December 1930, the Senate confirmed McNinch (47 to 11) as a member of the regulatory commission, governing public utility programs and energy resources. Despite Hoover's expectations, the short, unflappable North Carolinian soon boasted a progressive anti-monopoly record heralding the New Deal. Under Franklin Roosevelt, McNinch became the Federal Power Commission president, visiting the Netherlands in 1935 for the World Power Conference. McNinch also supported the New Deal's rural electrification programs, using Federal authority to escalate processes once begun through private industry. ${ }^{13}$ James B. Duke and Zebulon V. Taylor would likely have balked at such comprehensive changes.

In 1937, McNinch became the first director of the Federal Communications Commission (FCC), once appearing on the front cover of Time. McNinch opposed the manipulation of communications by political interests, stressing equal time for oppositional viewpoints. McNinch's biographical entry asserts his steadfast opposition to censorship. However, McNinch's defense of free speech reached its limit after actress Mae West irked the religious Southerner with one of her ribald witticisms on the air. During World War II, McNinch went back to his lawyerly roots, serving as special

13 "National Affairs: When is a Democrat?" from Time, 29 December 1930, available from http://www.time.com/time/magazine/article/0,9171,752716,00.html; Internet; accessed 9 August 2009; Powell, 184-85. 
assistant to the Attorney General until his retirement under the Truman administration. Frank Ramsay McNinch died on April 20, $1950 .^{14}$

Chief Walter Baxter Orr, the man most responsible for escalating the crisis in Charlotte, suffered little adversity for his conduct on August 25, 1919. Nor did Orr ever face perjury charges for contradicting his first testimony shortly after the "Battle of the Barn.” Unlike his mentor, Sheriff Newt Wallace, Orr lacked the patience to control large crowds. Relatively young for his newly-appointed rank, Walter Orr nonetheless faced a thankless situation. But one is judged by their actions under duress, and Orr's mishandling of the Dilworth situation speaks volumes. Chief Orr retained his position until March 26, 1926, when he retired after twenty years. Thereafter, Orr served as director of Charlotte's Sanitary Department, where he once more courted controversy over his zealous enforcement of sanitation across Charlotte. Walter Baxter Orr passed away on April 24, 1957, mourned as a lost part of "old Charlotte." 15

Attorney Marvin Lee Ritch continued to reside in Charlotte, coaching Charlotte High School's football team and maintaining his legal practice. However, Ritch suffered for his efforts on behalf of Piedmont workers. For his leadership during the Wiscasset Mills strike, Ritch paid over $\$ 500$ in fines and court costs, and he subsequently lost a 1920 bid for U.S. Congress as a "Square Deal” Democrat, largely due to an editorial smear campaign. Ann R. Brantley confirms that her father's continual endorsement of

\footnotetext{
14 “Power Men Scrutinized," from Time, 22 December 1930, available from http://www.time.com/time/magazine/article/0,9171,740824,00.html; Internet; accessed 26 February 2007; “QRX,” from Time, 16 May 1938, available from http:/www.time.com/time/magazine/article/0,9171,759694,00.html; Internet; accessed 26 February 2007; Powell, 184-85; McNinch interview.

${ }^{15}$ Donna Johnson, Descendants of James “Whistling” Orr, 2008, available from http://www.geocities.com/pawcreek.geo/orr/nti00120.htm; Internet; accessed 9 August 2009.
} 
liberal causes hurt his political career. But there were happier moments for Ritch. In April 1922, the widower married his wife's first cousin, Lois Wilson, an emancipated college graduate from a prominent Gaston County family. Within ten years, the Ritch family had grown to include two more daughters. ${ }^{16}$

Throughout the next two decades, Ritch represented a coterie of legal clients, including disabled mill workers, high-profile murder suspects, even a former Ku Klux Klan member. Ritch's expanding legal practice enabled him to build a house for $\$ 17,000$, which he ultimately lost during the Depression. During the Second World War, Ritch won two non-consecutive terms (1939-42) as a New Deal Democrat in the General Assembly, but lost to Clyde Hoey in a bid to succeed U.S. Senator Robert Reynolds. Thereafter, Ritch switched to divorce law, even while still coaching high school athletics. During the 1950s, Ritch supported integration of black athletes in North Carolina schools. Helped by state voting district reforms in 1966, Marvin Lee Ritch returned once more to the North Carolina General Assembly, at a venerable age of 77. But plagued by diabetes, Ritch suffered a stroke in 1971, and died in Charlotte at age $82 .{ }^{17}$

Concerning the South Carolina personalities, far less information is currently available. Franklin H. Knox, as mentioned previously, died in 1936, the same year much of the Piedmont's electric streetcar service converted to motorization. Benette Geer continued to act as a trustee to the Duke Endowment for the remainder of his life. During

\footnotetext{
${ }^{16}$ U.S. Bureau of the Census, 1930, Mecklenburg County, Charlotte, North Carolina; Charlotte Observer, 21 November 1919, 1; Gastonia Daily Gazette, 19 May 1920, 1-2; Lumberton Robesonian, 24 November 1919, 4-6; Brantley interview.

${ }^{17}$ Gastonia Daily Gazette, 9 July 1925; 13 November 1926, 6; 26 October 1927, 6; Lumberton Robesonian, 9 November 1943, 6; Statesville Record \& Landmark, 15 October 1923, 3; 12 June 1924, 4; 14 January 1929, 7; Burlington Daily Times-News, 26 April 1966, 2A; Marvin Lee Ritch, death certificate, 9 June 1971, North Carolina State Board of Health; Brantley interview.
} 
World War II, Geer came out of business retirement to serve as a Roosevelt appointee on the National Labor Relations Board, representing the textile industry's interests during arbitration. Venerated by Furman University for his philanthropic efforts, Benette E. Geer passed away in 1957. Ben Geer's service to South Carolina eventually resulted in the state's dedication of Geer Highway, a 25 mile stretch of U.S. Highway 276, connecting Greenville to Brevard, North Carolina. ${ }^{18}$

Despite the Columbia streetcar union's defeat, Ambrose A. Gerald continued his political career in South Carolina for a time. Gerald had represented Richland County, the state capital's home, at the Seventy-Third (1919-20) and Seventy-Fourth (1921-22) General Assemblies. Even as Columbia's strike entered its last throes, Gerald won a third term with the Seventy-Fifth General Assembly in November 1922. Gerald lost two bids for re-election in 1924 and 1926, but returned for his final term as Richland County representative in the Seventy-Eighth General Assembly (1929-30). Thereafter, Ambrose Gerald's paper trail appears to run out. ${ }^{19}$

Albert Essex Jones, the union organizer who sought to overturn the Piedmont establishment, has been less difficult to trace. His own streetcar union in Cincinnati foundered in March 1922, contemporaneous with similar setbacks in Charlotte and Knoxville, Tennessee. However, Jones's union standing improved shortly after his departure from Charlotte. His official report made no mention of his treatment by Zebulon Taylor, or his summary dismissal by Mayor McNinch. But evidently, AASERE President William D. Mahon did not hold Jones responsible for events in Charlotte. In

\footnotetext{
${ }^{18}$ Glenn, 31-33; 38-41.

${ }^{19}$ Walter Edgar, editor, Biographical Directory of the South Carolina House of Representatives (Columbia: University of South Carolina, 1974), 511-518; 534.
} 
October 1919, he became Eleventh Vice-President. As mentioned in Chapter Seven, Jones took part in the Columbia negotiations of 1920, without incurring the wrath of its city fathers. Jones later visited other imperiled union chapters across Ohio, Kentucky, and Tennessee. By August 1923, Jones had risen to Seventh Vice-President. But afterward, Jones's union activity seems to have tapered off. Cincinnati's 1930 census reports reveal Jones at age 55, still laboring as a streetcar conductor. Jones remained in Cincinnati, Ohio, until his death in 1962, at age $87 .{ }^{20}$

During the 1920s, unionism became a taboo subject in the region. Almost a decade after the Charlotte strike, major textile strikes erupted across the Piedmont over unionization. In 1927, the United Textile Workers began a recruitment drive in Henderson, North Carolina, where "stretch-outs" and wage cuts had angered workers. More drastic events took place in 1929, when the North Carolina mill towns of Marion and Gastonia witnessed strikes over union recognition. Both incidents, like the Charlotte Regional Streetcar Strike, ended with bloodshed and legal recriminations. Southern Public Utilities streetcar workers played no visible role during these textile strikes, owing largely to the fact they had no union organization to galvanize their support. By 1929, only Division 128 in Asheville remained extant. Moreover, labor efforts in Gastonia drew true radicals to the Piedmont, notably Communist Party leader William Z. Foster. Even if streetcar men held sympathies for the Loray Mill strikers, they were unlikely to become involved with actual labor radicalism, given their experiences ten years before. ${ }^{21}$

${ }^{20}$ Motorman and Conductor, Vol. 27, No. 11 (October 1919), 140; Vol. 29, No. 11 (October 1921), 117; Vol. 31, No. 4 (March 1922), 8; Vol. 32, No. 9 (August 1923), 1; U.S. Bureau of the Census, 1930, Cincinnati, Ohio.

${ }^{21}$ Salmond, 188-90; Allen Tullos, 134-71; Tindall, 341-53. 
The campaign for union representation was not, however, a total failure for the streetcar men. Charlotte's strike actually improved Southern Power's treatment of its transportation workers, especially after Taylor's death. Southern Public Utilities pay raises turned out to be permanent, and Loy Cloninger saved enough by late 1920 to purchase a home for his wife on South Tryon Street. Cloninger also sported a HarleyDavidson motorcycle, which he and his spouse rode every year to the Charlotte Fairgrounds. Cloninger's four children finished high school and his two sons later worked for Duke Power. Like many former conductors and motormen, L.C. Cloninger retrained for the city's new bus service. After years as a mechanic and part-time driver, Loy Cloninger retired in 1955 with a pension from City Coach, the contractor operating Duke Power's bus lines. Cloninger's later memories of City Coach seem to have been happier than his earlier recollections of working for Southern Public Utilities. ${ }^{22}$

Jesse B. Ashe's career at Southern Power also flourished in the years following the strike. Ashe often drove a streetcar through the Queens College district, where he became something of a favorite with the co-eds. But unlike Loy Cloninger, Ashe did not meet his future wife until shortly before he turned forty. In 1926, Ashe began a family and helped raise three sons. Soon after, Ashe became inspector of streetcars, at $\$ 150$ monthly. By the time Ashe retired from City Coach in 1955, a bus supervisor earned \$358 monthly. With this income, Jesse Ashe could afford to put one son through the University of North Carolina at Chapel Hill, one of his own unrealized dreams. ${ }^{23}$

\footnotetext{
${ }^{22}$ SPU workers received periodic raises every six months in 1920-21. (Motorman and Conductor, Vol. 29, No. 3 (February 1921), 2; Cloninger interview, 9-12).

${ }^{23}$ Southern Public Utilities Magazine, Vol. 5, No. 7, (December 15, 1919), 16; Ashe interview.
} 
But one wonders if the material improvements enjoyed by Southern Power's streetcar men were adequate compensation for their defeated effort to achieve true collective bargaining. We have already touched upon the suppression of Loy Cloninger's eyewitness account, and Jesse B. Ashe's selective memory of the strike. In 1933, Russell Campbell came to work as a streetcar conductor during Southern Public's final days. When interviewed in 1994, Campbell had been retired from Duke Power since 1974. As nephew to Assistant Superintendent T.R. Drum -- among those injured in the riot Campbell remembered well the chief lesson of the Charlotte Streetcar Strike. Former participants were "advised not to say too much about it," in order to prevent younger employees from "getting ideas" about unionism. Charlotte historian Dan Morrill also blamed newspaper publisher Wade Harris for obscuring the actual truth behind the strike, labeling the Observer as "a mouthpiece for corporate Charlotte." 24

Following World War II, the International Brotherhood of Electrical Workers once more sought to unionize Duke Power. Much as their Southern Power counterparts had done in 1919, Duke Power electricians assembled for a union vote in 1948. Herman Wolf recalled convincing his junior electricians that union organizers were untrustworthy agents. He further reasoned that "Mr. Adair," the union organizer, "stood to gain financially" from collecting union dues. Citing the company's welfare programs for retirees, Wolf warned his colleagues that union rules would require the company to end these services. Herman Wolf expressed his belief to Allen Tullos that his arguments convinced nearly all Duke's electrical workers to defeat the 1948 union vote. Harkening back to the Charlotte strike, Wolf concluded that AFL union organizers did not win any

\footnotetext{
${ }^{24}$ Maschal, 1E-2E.
} 
converts in 1919. This erroneous statement encapsulates the degree to which Duke Power's management discouraged - and distorted -- memories of the streetcar and electricians' strikes. Certainly, hundreds of pro-union transportation and utility workers once existed in Columbia, Spartanburg, and Charlotte, or historians and journalists would not consider today their wider significance to the Piedmont, the New South, or the postwar United States. ${ }^{25}$

So what should scholars and other readers learn from the preceding examples of Spartanburg, Charlotte, and Columbia? Spartanburg and Charlotte's 1919 transportation strikes inaugurated a regional anti-labor backlash in the Piedmont Carolinas, comparable to such events as Centralia, Washington's Armistice Day Massacre, or the 1920 Denver Tramway strike in Colorado. ${ }^{26}$ But in a larger sense, the Red Scare exerted a profound effect upon the Carolina Piedmont, especially in Charlotte, where industrial unions did not gain headway until the 1960s. Anti-labor arguments prevalent in 1919 still hold sway in conservative towns across the Piedmont, even as textile mills and fabric plants closed their gates and redeployed on foreign shores in the final quarter of the twentieth century.

${ }^{25}$ Herman Wolf admitted he had been in Concord, North Carolina, during the entire strike proceeding in 1919. Moreover, Wolf, as a company loyalist and operations manager, would not have supported union activity within his ranks. His creative interpretations of the IBEW Union Constitution almost brought about a lawsuit for misrepresentation. (Wolf interview).

${ }^{26}$ In early August 1920, Denver, Colorado witnessed a violent strike bearing similarities to the Charlotte tragedy. As strikebreakers escalated tensions, about two thousand sympathizers staged six demonstrations across Denver. Six were killed and fifty wounded before U.S. Army troops under General Leonard Wood restored order to the city. Hardly a friend to organized labor, General Wood nonetheless conceded the strikebreakers had provoked the townsfolk. (Ronald H. Cole and Clayton D. Laurie, The Role of Federal Military Forces in Domestic Disorders, 1877-1945 (insert publication information here), 271-72; Asinof, 197-202). 
Even today, the two Carolinas still compete for the lowest concentration of labor unions across the United States. ${ }^{27}$

Between the Wheels also addressed the ideals of Southern Progressivism at every level of Carolina Piedmont society. Governor Robert Cooper of South Carolina and Mayor Frank McNinch represent the elite political leaders who brokered labor compromises and promoted regulatory reforms, in keeping with the goals of President Wilson's "New Freedom.” Ambrose Gerald and Marvin Ritch both hailed from middleclass Carolina yeomanry, but they suffered frustrations in their respective efforts to combine labor reforms with state legislature. Finally, we observe working men such as Loy Cloninger and Jesse Ashe, whose hopes for better pay and improved futures translated into their support for a streetcar union.

Outside the Carolina Piedmont, some streetcar unions managed to weather the anti-union reaction during the 1920s, most notably Wheeling, West Virginia's Division 103. Unlike Columbia's isolated Division 590, Wheeling's streetcar union benefited from a truly regional labor network, the Ohio Valley Trades and Labor Assembly. Division 103 even sent organizers into Southern West Virginia, hoping in vain to unionize streetcar workers in coal towns, such as Princeton and Bluefield. Division 103, however, managed to rescue their company from receivership during the Great Depression, transforming Wheeling Traction Company into the employee-owned Cooperative Transit System, which served the city for three more decades. Whether

${ }^{27}$ Edward Martin, "N.C. Labor Efforts Written in Blood," from the Charlotte News, (5 September 1983), 1A-3A. For more on labor resistance in the post-World War II Carolinas, see Julian B. Roebuck and Mark Hickson III, The Southern Redneck (New York City: Praeger Publishers, 1982). 
Ambrose Gerald's South Carolina labor alliance could have mobilized a similar drive to purchase Columbia Railway after its 1925 decline is a matter for speculation. ${ }^{28}$

Division 590's defeat certainly did not extirpate the Palmetto capital's union presence, but judging from the city's overall decline in labor activism, and the Upcountry's relative quietude throughout the 1920s, the streetcar strike of 1922 reversed an entire decade's worth of progress. Embattled after the Charlotte strike of 1919, the Columbia Federation of Trades watched in trepidation as Franklin Knox engineered the downfall of streetcar unionism in two South Carolina cities. While Knox's two streetcar lines quickly fell into receivership, his victory against unionism discouraged further efforts to expand into the South Carolina Upcountry. Columbia's protracted transportation strike in 1922 affected the Piedmont region much in the same fashion that the National Railroad Shopmen's Strike halted labor progress across the country. Both cases reveal a dramatic rollback of union gains during World War I, weakening their state and federal support until the New Deal ushered in a new period of activism. ${ }^{29}$

Unfortunately, Piedmont streetcar workers did not figure prominently in these later struggles for industrial democracy. Their torch subsequently passed to oppressed textile workers who organized across the Carolinas during the Depression. Like the

${ }^{28}$ Amalgamated Association of Street and Electric Railway Employees, Division 103, Wheeling, West Virginia (WVU West Virginia Collection, Box 3); Motorman and Conductor, Vol. 19, No. 4 (March 1911), 18; Vol. 24, No. 3 (February 1916), 25; Phil Conley, West Virginia, Yesterday and Today (Charleston, West Virginia: West Virginia Publishing Company, 1937), 267-71; Tom Dunham, Wheeling in the $20^{\text {th }}$ Century (Bloomington University Press, Bloomington, Indiana, 2003), 7; Doug Fethering, Wheeling: an Illustrated History (Wheeling, West Virginia: Windsor Publications, 1983), 54-65.

${ }^{29}$ Colin J. Davis, Power at Odds: the 1922 National Railroad Shopmen's Strike (Urbana \& Chicago: University of Illinois Press, 1997), 166-72. 
participants in Charlotte's labor protest movement, these textile workers paid for their courage with blood and defamation.

Duke Power's trolleys are no more. However, like old trolley tracks beneath Charlotte's asphalt streets, the Queen City's historical tradition has emerged into public consciousness since the late 1970s. Owing to journalists and public historians, Charlotte's collective amnesia toward its strike has dissipated, helping to rekindle interest in trolleys as modern agents of local tourism and public transit. To a lesser extent, South Carolina cities, such as Columbia and Spartanburg have also revisited their New South roots as streetcar towns in recent decades. ${ }^{30}$

Charlotte's trolley debate seems to have accelerated in the 1980s, during the tenure of Mayor Harvey Gantt, the city's first African-American mayor. Part of Gantt's interest in the project lay in his concerns over rising traffic congestion in his everwidening city. However, the projected costs for surveys and construction deterred the city council from endorsing Gantt's plan. Eventually, Mayor Gantt abandoned this project to expand public transportation in Charlotte. ${ }^{31}$

${ }^{30}$ Joe Goodpasture, "Streetcar Riot," Charlotte Magazine, Vol. 6, No. 2, February 2001, 11; Richard Maschal, "Forgotten Night of Fear," Charlotte Observer, 23 August 1994, 1E-2E; Steve Snow, "Trolley Holds Deep Memories," Charlotte Observer, 14 January 1987, 10C; Ed Martin, "North Carolina Labor Efforts Written in Blood," Charlotte News, 5 September 1983, 1A-3A; Bill Beck, "Five Deaths Marred 1919 Charlotte Streetcar Strike," Charlotte News, 20 January 1979, 10A.

${ }^{31}$ Jack Claiborne, "Trolley Conscious," from Charlotte Observer, 12 August 1989, 12A; Eileen Curry, "Mayor Delays Vote on Trolley Study," from Charlotte Observer, 29 January 1985, 1B; Ted DeAdwyler, "Visitor Extols Virtues of Trolleys," from Charlotte News, 29 March 1984, 1C; "Gantt to Discuss U.S. Aid for Trolley Idea," from Charlotte Observer. 16 December 1983, 10B; Dan Morrill, "The Trolley Car," from Charlotte Observer, 24 April 1983, 4E; Jim Morrill, "Council Members Weigh the Need for Trolley System," from Charlotte Observer, 25 September 1984, 1B; Jim Morrill, "Trolley Clang Stifled as Council Delays Action," from Charlotte News, 25 September 1984, 1C; Lew Powell, "Close, But No Trolley," from Charlotte Observer, 24 April 
Enthusiasts such as Steve Snow and Dan Morrill kept trolley interests simmering until the next decade. In 1996, streetcars finally returned to Charlotte, using volunteer conductors instead of low-wage employees. A private group began efforts to restore the original Dilworth building for a new transportation museum. In late 2001, the Levine Museum of the New South also reevaluated the Dilworth barn's historical importance. ${ }^{32}$ In 2003, Dan Morrill and the Charlotte-Mecklenburg Historic Landmarks Commission appeared before the Mecklenburg County Board of Commissioners. Two potential sites were assessed for a new transportation museum, with Atherton Mill estimated at $\$ 3.4$ million, and the Dilworth Barn had been projected at $\$ 5.2$ million. On May 21, 2003, Mecklenburg County's board members voted 6 to 3 to preserve both sites. However, Dilworth's preservation bond fell through in 2007, and the site is under development. Retired Charlotte Observer reporter Jack Claiborne explained this tragedy as a case where preservation could not make a persuasive argument for profitability. ${ }^{33}$

1984, 3E; Lew Powell, "Tracking Trolleys," from Charlotte Observer, 17 April 1984, 3E; "Relics," from Charlotte Observer, 18 January 1984, 1B-2B; "Reviving Trolleys," from Charlotte Observer, 27 December 1983, 18A; Gretchen C.F. Shappert, "The Trolley Folly," from Charlotte News, 15 January 1985, 1B; Steven Snow, "Trolley Holds Deep Memories," from Charlotte Observer, 14 January 1987, 10C; Steven Snow, "Trolleys Work - Let's Get Them On Line Here," from Mecklenburg Neighbors, 15 April 1987, 14; Steven Snow, "Include Trolleys in Street Plans," from Mecklenburg Neighbors, 26 April 1987, 14; "Trolley Link," from Charlotte Observer, 3 September 1983, 18A; "Trolley Song," from Charlotte Observer, 22 November 1975, 18A; "Trolley Talk," from Charlotte Observer, 31 January 1985, 16A; "Trolleys Left Charlotte Tracks in 1938," from Charlotte News, 16 February 1978, 3.

${ }^{32}$ Ryan L. Sumner, Historical Background Statement, available from http://www.cmhpf.org/Surveys\&rstreetcarbarn.htm; Internet; accessed 22 April 2003.

${ }^{33}$ http://www.charlotte.com/mld/charlotte/news/columnists/dr traffic/5310034.htm; Internet; accessed 22 April 2003; http://www.athomecharlotte.com/charlottenews/01/aug01/worthy\%20investment.htm; Internet; accessed 22 April 2003; Jack Claiborne, interview with author, 18 September 2008. 
Unfortunately, no marker exists to commemorate the five slain men who fell on August 25, 1919. Few people recognize that these unarmed men, drawn from different walks of life, were mercilessly gunned down by Chief Walter B. Orr's police officers, augmented by strikebreakers. After Orr's trial, Judge F.B. Alexander predicted gravestones were not necessary to remember the strike for ages to come. Caldwell Houston, Walter Pope, J. D. Aldrich, William R. Hammond, and Claude Hinson deserved better remembrance. Though these five men were undeniably native Piedmont yeomen, the state and local authorities have yet to erect a marker to acknowledge their unjust deaths at the city's hands. It is almost as though these five men were foreign invaders, instead of workers voicing their opposition to strikebreakers in their city.

Across the post-war United States in 1919, terms such as "foreigner" and "outsider" were subject to elastic interpretations. Wartime hatreds toward Germany quickly translated into Red Scares against Bolshevik Russia, with American labor unions caught in a political no-man's land after the decline of Wilson's presidency. While the South experienced these same impulses, Piedmont Carolina employers and workers expressed a notable antipathy toward labor unions.

Yet, overstated myths of cultural independence and Protestant industry have obscured the wider view of North and South Carolina's mountain and upcountry folk. They did not need "foreign" agitators to feel anger and resentment toward low wages, long hours, and no benefits. However, while labor unions were not widely welcomed, neither were they unsupported in the Piedmont or the Blue Ridge Mountains, as evidenced by the AASERE campaign to connect Columbia and Asheville's streetcar unions through Spartanburg, Greenville, and ultimately, Charlotte. Historians should 
now reassess these brave men who challenged the powerful industrialists of yesterday. Despite the Carolina Piedmont's gradual losses of textile mill industry and culture, labor unions are still relevant to the region's future. We still need native-born labor advocates in the molds of Ambrose Gerald and Marvin Ritch, who can embrace progressive goals and work on behalf of today's Southern workers. Nearly a century after their efforts failed valiantly, American workers still languish between the wheels, even in this new era of Wal-Marts and Starbucks. 


\section{Primary Sources}

Alexander, Julia M. Charlotte in Picture and Prose. Charlotte, North Carolina, 1906.

Ashe, Jesse B. Interview by Allen Tullos. 13 June 1980. Recording. University of North Carolina at Chapel Hill, Southern Historical Collection, Louis Round Wilson Library.

Beck, William. "Five Deaths Marred 1919 Charlotte Streetcar Strike," from The Charlotte News, 20 January 1979, 10A.

Brantley, Ann Ritch. Interview by author. 19 September 2008.

Burkholder, Charles J. to Mayor and Board of Aldermen, Salisbury, N.C. [franchise Agreement] 29 April 1919.

Burlington Daily Times-News. 26 April 1966.

Business and Professional Directory. Jackson-Hilder Publication Co., Wheeling News Lithographic Company, Wheeling, West Virginia, 1902.

Callin's Wheeling City Directory 1919-1920. R.L. Polk Publishers, Wheeling, West Virginia, 1919.

Carraway, Leake. Queen Charlotte: The Hydro Electric Centre. Greater Charlotte Club, Charlotte, North Carolina, 1913.

Charlotte-Mecklenburg Historic Landmarks Commission Report. 7 January 1977. Available from http://www.cmhpf.org/S\&RR/duke.html. Internet. Accessed 22 April 2003.

Charlotte News. [25 August 1919 - 9 August 1920]

Charlotte Observer. [10 August -- 23 November 1919]

Charlotte Observer. 1 August 2001. Available from http://www.athomecharlotte.com/charlottenews/01/aug01/worthy\%20investment.htm. Internet. Accessed 22 April 2003.

Claiborne, Jack. "Trolley Conscious," from Charlotte Observer. 12 August 1989, $12 \mathrm{~A}$.

Claiborne, Jack. Interview with author. 18 September 2008.

Clement, Josephine. Interview by Kathryn Nasstrom. 13 July and 3 August 1989. Transcript. University of North Carolina at Chapel Hill, Southern Historical 
Collection, Louis Round Wilson Library.

Cleveland Press. 28 September 1928.

Cloninger, Loy C. Interview by Allen Tullos. 18 June 1980. Transcript. University of North Carolina at Chapel Hill, Southern Historical Collection, Louis Round Wilson Library.

Columbia Record. [28 January 1920 - 20 March 1922]

Columbia State. [1 July 1919 - 26 August 1919]

Curry, Eileen. "Mayor Delays Vote on Trolley Study," from Charlotte Observer. 29 January 1985, 1B.

DeAdwyler, Ted. "Visitor Extols Virtues of Trolleys," from Charlotte News. 29 March 1984, 1C.

Dodson, Ila H. Interview by Allen Tullos. 23 May 1980. Transcript. University of North Carolina at Chapel Hill, Southern Historical Collection, Louis Round Wilson Library.

Duke, James Buchanan. Indenture and Deed of Trust Establishing the Duke Endowment. 23 October 1925. Quoted in J.W. Jenkins, James B. Duke: Master Builder, Spartanburg, South Carolina: The Reprint Company, 1927.

First Inaugural Address of Robert A. Cooper, Governor to the General Assembly of South Carolina. (Regular Session, 21 January 1919) Columbia, South Carolina: Gonzales and Bryan, State Printers, 1919.

Forbes, Bertie Charles. The Men Who Are Making America. New York: B.C. Forbes Publishing Company, Inc., 1917.

Freeman, J.W. to Southern Public Utilities Co. [settlement agreement] 20 May 1918.

"Gantt to Discuss U.S. Aid for Trolley Idea," from Charlotte Observer. 16 December 1983, 10B.

Gastonia Daily Gazette. 19 May 1920 - 26 October 1927.

Goodpasture, Joseph. “A Lightbulb Moment," from Charlotte Magazine, Vol. 6, No. 2, (February 2001), 10.

Goodpasture, Joseph. "Streetcar Riot," from Charlotte Magazine, Vol. 6, No. 2, (February 2001), 11. 
Greenville Daily News. [1919-20]

Journal \& Carolina Spartan.

Kansas City Star. [28 March 1918]

Labor Advocate of Columbia. [1 August 1919 - 19 September 1919]

Lea v. Southern Public Utilities Co. and Charlotte Electric Railway Co. Mecklenburg County, 449. NC Supreme Court 1918.

Lumberton Robesonian. 24 November 1919 - 9 November 1943.

Martin, Edward. "N.C. Labor Efforts Written in Blood," from Charlotte News, 5 September 1983, 1A-3A.

Maschal, Richard. "Forgotten Night of Fear," from Charlotte Observer, 23 August 1994, 1E-2E.

McCall, Alice L.M. Interview by Anna Causby. 24 May 1979. Transcript. Special Collections, J. Murrey Atkins Library, University of North Carolina at Charlotte.

McCall, Johnston V. Interview by Anna Causby. 24 May 1979. Transcript. Special Collections, J. Murrey Atkins Library, University of North Carolina at Charlotte.

McNinch, Samuel S. III. Interview by author. 18 September 2008. Transcript.

Morrill, Dan. “The Trolley Car,” from Charlotte Observer. 24 April 1983, 4E.

Morrill, Jim. "Council Members Weigh the Need for Trolley System," from Charlotte Observer. 25 September 1984, 1B.

Morrill, Jim. "Trolley Clang Stifled as Council Delays Action," from Charlotte News. 25 September 1984, 1C.

Motorman and Conductor [1895-1928]

"National Affairs: When is a Democrat?" from Time (29 December 1930). http://www.time.com/time/magazine/article/0,9171,752716,00.html. Internet. Accessed 9 August 2009.

National Archives and Records Administration, U.S. Department of Justice, Investigations on Labor, Chattanooga, Tennessee, Box 117.

National Archives and Records Administration, U.S. Department of Labor, Mediation and Conciliation Branch, Charlotte, North Carolina, Box 111. 
National Industrial Conference Board. The Cost of Living Among Wage-Earners. Special Report Number 8, May 1920.

New York Times. 31 August 1917, 27 August 1919.

Norcross, P.H. Spartanburg, S.C. Report on Water Supply. Atlanta: Foote and Davies Company, 1924.

Pease, J. Norman. Interview by Edward Perzel. 22 May 1979. Transcript. Special Collections, J. Murrey Atkins Library, University of North Carolina at Charlotte.

Powell, Lew. "Close, But No Trolley," from Charlotte Observer. 24 April 1984, 3E. . “Tracking Trolleys,” from Charlotte Observer, 17 April 1984, 3E.

"Power Men Scrutinized," from Time (22 December 1930). http://www.time.com/time/magazine/article/0,9171,740824,00.html. Internet. Accessed 26 February 2007.

“QRX," from Time (16 May 1938). http://www.time.com/time/magazine/article/0,9171,759694,00.html. Internet. Accessed 26 February 2007.

Raleigh News and Observer. 1919.

"Relics," from Charlotte Observer. 18 January 1984, 1B-2B.

Report of the Industrial Commission on Trusts and Industrial Combination, Vol. 13. Washington D.C., 1901.

“Reviving Trolleys,” from Charlotte Observer. 27 December 1983, 18A.

Second Inaugural Address of Robert A. Cooper, Governor to the General Assembly of South Carolina, Regular Session. (18 January 1921) Columbia, S.C., Gonzales and Bryan, State Printers, 1921.

Shannonhouse, F.M. "How the Recall Worked in Charlotte," from the National Municipal Review. Vol. IX, No. 1. (January 1920).

Shappert, Gretchen C.F. "The Trolley Folly,” from Charlotte News. 15 January 1985, $1 \mathrm{~B}$.

Simpson, J.W. Spartanburg City and Spartanburg County, South Carolina. Nashville, Tennessee: Brandon Printing, 1903. 
Snow, Steven. "Trolley Holds Deep Memories," from Charlotte Observer, 14 January 1987, 10C.

Snow, Steven. "Trolleys Work - Let's Get Them On Line Here," from Mecklenburg Neighbors, 15 April 1987, 14.

Snow, Steven. "Include Trolleys in Street Plans," from Mecklenburg Neighbors, 26 April 1987, 14.

Southern Power Company and Southern Public Utilities Co. to Belbros Mills Inc. [business contract] 1 June 1919.

Southern Public Utilities Company to Charlotte Street Railway Union. [contract] 16 August 1919.

Southern Public Utilities Company to Greenville Street Railway Union. [contract] 2 September 1919.

Southern Public Utilities Company to Charlotte Street Railway Union. [contract] 4 September 1919.

Southern Public Utilities Magazine. 1915-1921.

Spartanburg County Criminal Cases, Alphabetical Session Index (1909-59). (Roll SP52) South Carolina Historical Archives.

Spartanburg Herald. 1919-1920.

Spurr, Henry C. Public Utilities Reports Annotated. Rochester, New York: Public Utilities Reports, Inc., 1920.

Randolph County Courier Tribune. 21 April 1921. Available from http://www.asheboro.com/ons/obits/1920-1929(S-T).html. Internet. Accessed 22 April 2003.

Star of Zion. May-August 1919.

Statesville Daily Record. 4 March 1954 - 31 May 1954.

Statesville Record \& Landmark. 15 October 1923 - 14 January 1929.

Stroud, Daisy. Interview by Melinda Desmarais. 20 June 2001. Transcript. Special Collections, J. Murrey Atkins Library, University of North Carolina at Charlotte.

Thirtieth Reports of the Department of Labor and Printing of the State of North Carolina, 1916. Raleigh: Edwards \& Broughton Printers, 1917. 
Thirty-Second Reports of the Department of Labor and Printing of the State of North Carolina, 1919-20. Raleigh: Edwards \& Broughton Printers, 1921.

Thomas, Aileen. Interview by Jane White. 22 May 1979. Transcript. Special Collections, J. Murrey Atkins Library, University of North Carolina at Charlotte.

"Thomas Edison's Firm Installed Trolley to Dilworth," from Charlotte Observer. 27 June 1982, Special Advertising Section, 1-2.

Trade Review of Columbia. 17 October 1919 - 9 April 1920.

“Trolley Link,” from Charlotte Observer. 3 September 1983, 18A.

“Trolley Song,” from Charlotte Observer. 22 November 1975, 18A.

“Trolley Talk," from Charlotte Observer. 31 January 1985, 16A.

“Trolleys Left Charlotte Tracks in 1938," from Charlotte News. 16 February 1978, 3A.

Twenty-First Reports of the Department of Labor and Printing of the State of North Carolina, 1907. Raleigh: E.M. Uzzell \& Co. State Printers and Binders, 1908.

Vaughan, John. "Lots of Neighborhoods Might Like a Trolley," from Charlotte News. 16 June 1984, 1B.

Washington Post. 22 October 1918.

West Virginia University, West Virginia History Collection. Division 103 of the Amalgamated Association of Street and Electric Railway Employees of Wheeling, West Virginia.

West Virginia University, West Virginia Historical Collection. Papers of the Ohio Valley Labor and Trade Assembly.

Wheeling Intelligencer. 1919-20.

Wister, Emory. Interview by Edward Perzel. 23 May 1979. Transcript. Special Collections, J. Murrey Atkins Library, University of North Carolina at Charlotte.

Wolf, Herman. Transcript by Allen Tullos. 15 July 1980. Transcript. University of North Carolina at Chapel Hill, Southern Historical Collection, Louis Round Wilson Library. 


\section{Secondary Sources}

Adams, Graham Jr. Age of Industrial Violence, 1910-1915. New York \& London: Columbia University Press, 1966.

Asinof, Eliot. 1919: America's Loss of Innocence. Donald Fine, Inc.: New York City, NY, 1990.

Annett, M.M.S. Bluefield in Vintage Postcards. Arcadia Publishing: Charleston, SC, 2004.

Archer, William R. Images of America: Bluefield. Arcadia Publishing, Charleston, SC, 2000 .

Charleston, SC, 2001.

. Images of America: Mercer County. Arcadia Publishing,

. Images of America: Princeton. Arcadia Publishing, Charleston, SC, 2006.

Babcock, Robert H. “'Will You Walk? Yes, We'll Walk': Popular Support for a Street Railway Strike in Portland, Maine," from Labor History, Vol. 35, No. 3 (Summer 1994).

Bionaz, Robert E. Death of a Union. Available from

http://userwww.sfsu.edu/ epf/1996/street.html. Internet. Accessed 22 April 2003.

Bjorkman, Edwin, editor. Charlotte: a Guide to the Queen City of North Carolina. Charlotte: News Printing House, 1939.

Blythe, LeGette, and Charles R. Brockmann. Hornet's Nest: the Story of Charlotte and Mecklenburg County. Charlotte: McNally of Charlotte, 1967.

Brecher, Jeremy. Strike! Boston, Massachusetts: South End Press, 1997.

Brody, David. Labor in Crisis: the Steel Strike of 1919. Urbana and Chicago: University of Illinois Press, 1965.

Brooke, Jonathan. Tent and Trench. Spartanburg County Historical Association, 2006. Available from http://www.schistory.net/campwadsworth/contents.html. Internet. Accessed 15 February 2008.

Boyd, Peter. History of the Northern West Virginia Panhandle. Topeka: Historical Publishing Co., 1927.

Burran, James A. "Labor Conflict in Urban Appalachia: The Knoxville Streetcar Strike 
of 1919.” Tennessee History Quarterly, Vol. 38, No. 1, (Spring 1979), 62-78.

Burts, Robert M. Richard Irvine Manning and the Progressive Movement in South Carolina. Columbia: University of South Carolina Press, 1973.

Carlton, David. Mill and Town in South Carolina 1880-1920. Baton Rouge and London: Louisiana State University Press, 1982.

Chace, James. 1912: Wilson, Roosevelt, Taft \& Debs - the Election that Changed the Country. New York: Simon \& Schuster, 2004.

Cole, Ronald H. and Clayton D. Laurie. The Role of Federal Military Forces in Domestic Disorders, 1877-1945. (insert publication information here)

Coleman, Alan and Ken Humphreys. Guide to Past \& Present Traction Systems in North Carolina. Piedmont and Western Model Railroad Club, 2008. Available from http://www.pwrr.org. Internet. Accessed on 12 June 2009.

Davis, Colin J. Power at Odds: the 1922 National Railroad Shopmen's Strike. Urbana and Chicago: University of Illinois Press, 1997.

DeMatteo, Arthur E. "The Downfall of a Progressive: Mayor Tom L. Johnson and the Cleveland Streetcar Strike of 1908." Ohio History 104 (Winter-Spring 1995), 24-41.

Dewees, Donald N. "Decline of the American Street Railway." Traffic Quarterly 24 (October 1970), 563-581.

Durden, Robert F. Bold Entrepreneur: A Life of James B. Duke. Durham, NC: Carolina Academic Press, 2003.

Edgar, Walter, editor. Biographical Directory of the South Carolina House of Representatives. Columbia: University of South Carolina, 1974.

Edgar, Walter. South Carolina: a History. Columbia: University of South Carolina Press, 1998.

Edwards, P.K. Strikes in the United States 1881-1974. New York City, NY: St. Martin's Press, 1981.

Fetters, Thomas T. Palmetto Traction. Forty Fort, PA: Harold E. Cox, 1978.

Fetters, Thomas T. and Peter W. Swanson. Piedmont \& Northern: The Great Electric System of the South. San Marino, CA: Golden West Books, 1976.

Filippelli, Ronald L., editor. Labor Conflict in the United States. New York \& London: Garland Publishing Company, 1990. 
Fink, Gary M. and Merl E. Reed, editors. "Essays in Southern Labor History: Selected Papers, Southern Labor History Conference, 1976." Westport, Conn.: Greenwood Press, 1977.

Foner, Philip S. "The IWW and the Black Worker." Journal of Negro History 55, 1. (January 1980).

Foner, Philip S. History of the Labor in the United States: Volume VII: Labor and World War I, 1914-1918. International Publishers, New York City, 1987.

Foner, Philip S. History of the Labor in the United States: Volume VIII: Postwar Struggles, 1918-1920. International Publishers, New York City, 1988.

Foster, Caroll and Mark Olencki. Spartanburg Revisited. Spartanburg: Hub City Writers Project, 2007.

Foster, Vernon. Spartanburg: Facts, Reminiscences, and Folklore. Spartanburg: Spartanburg County Foundation, 1998.

Glenn, L. M. Bennette Eugene Geer: a Biographical Sketch. Spartanburg, S.C.: Keys Printing Company, 1956.

Grantham, Dewey. Southern Progressivism: The Reconciliation of Progress and Tradition. University of Tennessee Press, Knoxville, 1983.

Greenwood, Janette T. The Black and White Better Classes in Charlotte. University of North Carolina Press: Chapel Hill \& London, 1994.

Grubbs, Frank L. Jr. The Struggle for Labor Loyalty. Durham, N.C.: Duke University Press, 1968.

Grundy, Pamela. Learning to Win: Sports, Education, and Social Change in TwentiethCentury North Carolina. Chapel Hill: Univ. of N.C. Press, 2001.

Hale, Grace E. Making Whiteness. New York: Pantheon Books, 1998.

Hanchett, Thomas W. Sorting out the New South City. Chapel Hill \& London: University of North Carolina Press, 1998.

Harkey, W. Hugh. More Tales from the Hornet's Nest. Charlotte, N.C.: Hornet's Nest Productions, 1992.

Hemmingway, Theodore. "Prelude to Change: Black Carolinians in the War Years, 1914-1920.” Journal of Negro History 65, 1. (Summer 1980). 
Henry, Sarah. "The Strikers and their Sympathizers: Brooklyn in the 1895 Trolley Strike,” from Labor History 32, (Summer 1991) 329-353.

http://landmarkscommission.org/S\&RR/HelmsBell.html. Internet. Accessed 17 February 2009.

http://www.alumni.unc.edu/learning/basketball.htm. Internet. Accessed 15 March 2003. http://www.cmstory.org/history/hornets/senators.htm. Internet. Accessed 15 March 2003.

http://www.cmhpf.org/Surveys\&rstreetcarbarn.htm. Internet. Accessed 22 April 2003.

Huff, Archie Vernon Jr. and Archie Vernon Huff. Greenville: History of the City and County in the South Carolina Piedmont. Columbia: University of South Carolina, 1995.

James, Felix. "Robert Russa Moton and the Whispering Gallery after World War I," from Journal of Negro History 62, 3. (July 1977).

Jenkins, J.W. James B. Duke: Master Builder. Spartanburg, S.C.: The Reprint Company, 1927.

Jones. Elliot. The Trust Problem in the United States. New York City: MacMillan Company, 1921.

Jones, Jr., James B. "The Other Side of the "Dynamo of Dixie": Class Consciousness and Worker Solidarity in Urban Tennessee: The Chattanooga Carmen's Strikes of 1899-1917.” Tennessee History Quarterly 52, 2. (Summer 1993).

Johnson, Donna. Descendants of James “Whistling” Orr. 2008. Available from http://www.geocities.com/pawcreek.geo/orr/nti00120.htm. Internet. Accessed 9 August 2009.

Kelly, Brian. Race, Class, and Power in the Alabama Coalfields, 1908-21. Urbana and Chicago: University of Illinois Press, 2001.

Leatherwood, Jeffrey M. "Between the Wheels." Tuskasegee Valley Historical Review 10. (Spring 2004). Cullowhee: Western Carolina University, Department of History.

Lens, Sidney. The Labor Wars. Doubleday \& Company, Inc.: Garden City, New York, 1973.

Letwin, Daniel. Alabama Coal Miners, 1878-1921: The Challenge to Interracial Unionism. University of North Carolina Press: Chapel Hill, 1998. 
Levinson, Edward. I Break Strikes: The Technique of Pearl L. Bergoff. New York City: Robert M. McBride, 1935.

Link, Arthur. Woodrow Wilson and the Progressive Era, 1910-1917. New York: Harper Brothers, 1954.

Link, William. The Paradox of Southern Progressivism, 1880-1930. Chapel Hill: University of North Carolina Press, 1992.

Mahon, William D. "What are the Relations of Capital to Labor and to What Extent and in What Manner Should the Church Occupy Itself with this Problem." Motorman and Conductor 5 (January 1899), 1-3.

Malloy, Scott. Trolley Wars: Streetcar Workers on the Line. Smithsonian Institute Press, Washington D.C. and London, 1996.

Maynor, Joseph. Duke Power: the First Seventy-Five Years. Charlotte: Duke Power Inc., 1979.

McCartin, Joseph A. Labor's Great War. Chapel Hill, NC: University of North Carolina Press, 1997.

Meier,August and Elliott Rudwick. "The Boycott Movement against Jim Crow Streetcars in the South, 1900-1906." Journal of American History, 55, 4, (March 1969), 756-775.

Mercer County Historical Society. Mercer County History. Princeton WV: Mercer County Historical Society, Inc., 1987.

Miller, Mark S., editor. Working Lives. New York City, NY: Pantheon Books, 1980.

Millikan, William. A Union against Unions. St. Paul, Minnesota: Minnesota Historical Society Press, 2001.

Minchin, Timothy J. Fighting Against the Odds. Miami: University Press of Florida, 2005.

Mitchell, David. 1919: Red Mirage. MacMillan Company: New York City, NY, 1970.

Mitchell, Miriam G., and Edward S. Perzel. The Echo of the Bugle Call: Charlotte's Role in World War I. Charlotte: Heritage Printers, Inc., 1979.

Molloy, Scott. Trolley Wars: Streetcar Workers on the Line. Smithsonian Press: Washington D.C., 1996. 
Moore, John Hammond. Columbia and Richland County. University of South Carolina Press: Columbia, South Carolina, 1993.

Moreton, Bethany. To Serve God and Wal-Mart. Cambridge, Massachusetts: Harvard University Press, 2009.

Morrill, Dan L. The New South Elite in Control. Available from http://danandmary.com/historyofcharch10.htm. Internet. Accessed 18 March 2003.

. "Dilworth's Early History." Available from

http://www.cmhpf.org/kids/neighborhoods/Dilworth-early.html. Internet. Accessed 23 March 2009.

. "A Brief History of the Mule-drawn or Horse-drawn Streetcar System in Charlotte, North Carolina 1883-1891." [unpublished research paper] 27 November 1991.

Mowry, George E. Theodore Roosevelt and the Progressive Movement. Hill and Wang, New York, 1946.

Murray, Robert K. "Communism and the Great Steel Strike of 1919," Mississippi Valley Historical Review 38, 3, (Dec. 1951).

Norwood, Stephen H. "Bogalusa Burning: The War against Biracial Unionism in the Deep South, 1919," from Journal of Southern History, 63, 3, (August 1997). . Strikebreaking and Intimidation: Mercenaries and Masculinity in Twentieth-Century America. (University of North Carolina Press: Chapel Hill \& London), 2002.

Norvill, Stanley B. and William Tuttle Jr. "Views of a Negro during the 'Red Summer' of 1919.” Journal of Negro History 51, 3 (Jul. 1966).

Olds, Marshall. The High Cost of Strikes. New York City: G.P. Putnam \& Knickerbocker Press, 1921.

Onasch, William. “The Streetcar Strikes of 1917-18," Kansas City Labor History Bus Tour, 1992. [on-line article] Available from http://www.kclabor.org/streetcar strikes of 1917.htm. Internet. Accessed 13 February 2007.

Ovens, David. If This Be Treason. Charlotte: Heritage House, 1957.

Peterson, Florence. Strikes in the United States. (Bulletin No. 651, August 1937), Government Printing Office: Washington D.C., 1938. [Reprinted by Scholarly 
Press: St. Clair Shores, Michigan, 1971].

Powell, William S., editor. Dictionary of North Carolina Biography. Volume 1. Chapel Hill: University of North Carolina Press, 1979. . Dictionary of North Carolina Biography. Volume 4. UNC Press: Chapel Hill \& London, 1991.

Rankin, John. The Early History and Development of Bluefield, West Virginia. Radford VA: Commonwealth Press, 1976.

Ray, Gerda. "We Can Stay Until Hell Freezes Over," from Labor History 36, 3. (Summer 1995) 403-425.

Reich, Steven A. "Soldiers of Democracy: Black Texans and the Fight for Citizenship," Journal of American History, 82, 4. (March 1996).

Roback, Jennifer. "The Political Economy of Segregation: The Case of Segregated Streetcars," Journal of Economic History, 46, 4. (December 1986), 893-917.

Robison, Elijah L. The Streetcar Strike of 1916-17: 'Scabs,' Conspiracies, and Lawlessness in Springfield, Missouri. Springfield: Greene County Archives Bulletin, 2004.

Roebuck, Julian B. and Mark Hickson III. The Southern Redneck. New York City: Praeger Publishers, 1982.

Scott, Carole E., and Richard D. Guynn, "The Atlanta Streetcar Strikes," Georgia Historical Quarterly 84. (Fall 2000).

Shaw, Carol. A City in Conflict: The 1919 Charlotte Streetcar Strike. [unpublished honors essay] University of North Carolina at Chapel Hill, 1980.

Simon, Bryant. A Fabric of Defeat: The Politics of South Carolina Millhands, 19101948. Chapel Hill: The University of North Carolina Press, 1998.

Smith, Gene. When the Cheering Stopped. New York: William Morrow, 1971.

Smith, Robert M. From Blackjacks to Briefcases. Ohio University Press: Athens, OH, 2003.

St. Clair, David J. "The Motorization and Decline of Urban Public Transit, 1935-1950." Journal of Economic History, 41, 3. (September 1981).

Stromquist, Shelton. Reinventing the People. Chicago: University of Illinois Press, 2006. 
Sumner, Ryan L. Historical Background Statement on Dilworth Car Barn. Available from http://www.cmhpf.org/Surveys\&rstreetcarbarn.htm. Internet. Accessed 22 April 2003.

Teter, Betsy W. Textile Town. Spartanburg: Hub City Writers Project, 2002.

Tindall, George B. The Emergence of the New South: 1913-1945. Baton Rouge: Louisiana State University Press and the University of Texas, 1967.

Tullos, Allen. Habits of Industry, White Culture and the Transformation of the Carolina Piedmont. Chapel Hill: University of North Carolina Press, 1989.

Turner, Walter. "Development of Streetcar Systems in North Carolina." Available from www.cmhpf.org. Internet. Accessed 24 August 2006.

Tuttle, William M., Jr. "Contested Neighborhoods and Racial Violence: Prelude to the Chicago Riot of 1919.” Journal of Negro History, 55, 4. Oct. 1970.

Tyler, Robert. "The United States Government as Union Organizer: The Loyal Legion of Loggers and Lumbermen," Mississippi Valley Historical Review 47, 3. (December 1960).

Wakstein, Allen. "The Origins of the Open Shop Movement." Journal of American History 51, 3. (December 1964).

Wetherington, Mark V. "Street Car City: Knoxville, Tennessee, 1876-1947," East Tennessee Historical Society 54-55 (1982, 1983), 70-110.

Williams, John Alexander. Review of "Essays in Southern Labor History: Selected Papers, Southern Labor History Conference, 1976." Journal of Southern History, 44, 2. (May 1978), 321-323.

Williamson, Thames Ross. Readings in American Democracy. Boston: D.C. Heath and Company, 1922.

Woodward, C. Vann. Origins of the New South: 1877-1913. Baton Rouge: Louisiana State University Press and the University of Texas, 1951 [1971].

Yellen, Samuel. American Labor Struggles. New York City: Harcourt, Brace and Company, 1936. 


\section{Jeffrey M. Leatherwood}

1064 Van Voorhis Rd., Apt. J126

Morgantown WV 26505

(304) 293-3728

\section{Education}

Ph.D. History

West Virginia University

December 2009

M.A. History

Western Carolina University

August 2004

B.S. History

Western Carolina University

December 1999

B.A. English

Western Carolina University

August 1996

\section{Doctoral Fields}

Examination Fields: $19^{\text {th }}$ and $20^{\text {th }}$ Century U.S. History, Environmental and Urban.

Teaching Fields: U.S. History, World History, and Military History.

Research Fields: Civil War, Gilded Age, Progressive Era, and the World Wars.

\section{Doctoral Dissertation:}

"Between the Wheels: Quest for Streetcar Unionism in the Carolina Piedmont, 1919-22." Director: Dr. Ken Fones-Wolf.

Committee: Dr. Elizabeth Fones-Wolf, Dr. Michal McMahon, and Dr. Pete Carmichael.

Outside Reader: Dr. Gerald Schwartz (Professor Emeritus) Western Carolina University.

\section{Master's Thesis:}

"Nine from Aberdeen: Colonel Thomas J. Kane and the Genesis of U.S. Army Ordnance Bomb Disposal, 1941-1945."

Director: Dr. David R. Dorondo.

Committee: Dr. James Lewis, Dr. Gerald Schwartz.

\section{Teaching Positions:}

Lecturer: $\quad$ West Virginia University $\quad$ (May 2008 to present)

- Entrusted with sophomore-level electives in Military History and the Gilded Age.

- Opportunity to begin teaching Modern World History, including Honors students.

Instructor: $\quad$ West Virginia University $\quad$ (August 2005 to May 2008)

- Independent course instruction, with periodic evaluation from academic advisors.

- Served one semester as a teaching assistant in the Modern Military History survey.

Teaching Assistant: $\quad$ West Virginia University $\quad$ (August 2004 to May 2005)

- Led discussion groups, graded examinations, and rendered multimedia assistance. 


\section{Courses Taught:}

Growth of the Nation (Pre-Contact to 1865)

- Research projects involving first-person perspectives in Early American history.

- Development of Power Point lectures with interactive multimedia and animations.

Making Modern America (1865 to Present)

- Research projects involving manmade and natural disasters in Modern America.

- Integration of relevant documentary and multimedia components into lectures.

Modern World History (1450 to Present)

- Comparative readings in World History literature, focusing on global imperialism.

- Film review essays, based on primary articles, secondary works, and critical analysis.

Modern Military History (1450 to Present)

- Multimedia and standard lectures on developments in military structure and thought.

- Research projects based upon academic readings, examining significant battles.

\section{Research Positions:}

Graduate Research Assistant: Western Carolina University

(2003-2004)

- Assistant to Dr. William Anderson, editing the Reverend John H. Payne Collection.

- Assistant to Dean of Graduate School, researching yearly alumni contributions.

- Assistant to Chair of History Department, general clerical and printing tasks.

\section{Scholarly Publications:}

\section{Manuscripts:}

"Nine from Aberdeen: Colonel Thomas J. Kane and the Genesis of U.S. Army Ordnance Bomb Disposal, 1941-1945." Under contract -- Cambridge Scholars Publishing, United Kingdom (Spring 2011).

\section{Peer-Reviewed Journal Articles:}

"Curious Dogmas: Rise and Fall of the Greenback Labor Party in West Virginia, 18761882," for West Virginia History (Under revision for Spring 2010)

"Grant us a Contract: Spartanburg as Prelude to the Carolina Regional Streetcar Strike of 1919,” in South Carolina Historical Magazine (Spring 2009).

"Between the Wheels: the 1919 Charlotte Streetcar Strike," in Tuckasegee Valley Historical Review. (Spring 2004). 


\section{Book Reviews and Textbook Evaluations:}

Evaluation of "Expeditions in World History: the Dynamics of Continuity \& Change in Human Societies," by John F. Chuchiak, Ahmed Ibrahim, and Dale Streeter. Publication under Wadsworth/Cengage Learning. (Summer 2009)

Review of "Mountaineers are Free: A History of the West Virginia National Guard," by Kenneth R. Bailey, in West Virginia History. (Spring 2009)

\section{Encyclopedia Articles:}

"Andrew Jackson," in World and its Peoples, edited by Leon Gray. London: Aquithie Editorial Limited and Brown Reference Group (2008).

"Jefferson, Madison, and the War of 1812," in World and its Peoples, edited by Leon Gray. London: Aquithie Editorial Limited and Brown Reference Group (2008).

"Vietnam War," in West Virginia Encyclopedia, edited by Ken Sullivan and Debby Sonis. Charleston, WV: West Virginia Humanities Council (2006), 736-737.

"World War I," in West Virginia Encyclopedia, edited by Ken Sullivan and Debby Sonis. Charleston, WV: West Virginia Humanities Council (2006), 810.

\section{Fellowships, Grants, and Honors:}

- Robbins Graduate Fellowship, West Virginia University, Eberly School of Arts and Sciences. (Fall 2008)

- Chitwood Graduate Fellowship, West Virginia University, Eberly School of Arts and Sciences. (Academic Year 2008/09)

- Chitwood Graduate Fellowship, West Virginia University, Eberly School of Arts and Sciences. (Academic Year 2007/08)

\section{Conference Organizations:}

Executive Planning Committee for WVU Rush D. Holt Conference (2009)

Advertising Committee for WVU Rush D. Holt Conference (2007)

Publication Designer for WCU Cherokee History Conference (2003)

\section{Conference Panels \& Presentations:}

"Learning Approaches to the Galveston Storm of 1900," from Teaching with Disasters, Discussion Panel from the WVU Rush D. Holt Conference, held at the WVU Mountainlair Building, April 3, 2009. 
"Grant us a Contract: Spartanburg as Prelude to the Carolina Regional Streetcar Strike of 1919," presented to WV Phi Alpha Theta Conference, held at West Virginia Wesleyan College, March 22, 2008.

"Grant us a Contract: Spartanburg as Prelude to the Carolina Regional Streetcar Strike of 1919," presented to the South Carolina Historical Association, held at South Carolina Archives and History Center, March 1-2, 2008.

"Curious Dogmas: The Rise and Fall of Greenback Labor in West Virginia," presented to the WVU Rush D. Holt Conference, held at the Waterfront Plaza in Morgantown, WV, April 13-14, 2007.

WVU Research Horizons Day, held at the Mountainlair Ballroom, April 5, 2007.

"Forgotten Front: U.S. Army Ordnance Bomb Disposal Squads and National Defense, 1941-45," presented to the WVU Rush D. Holt Conference, held at the WVU Mountainlair Building, March 3-5, 2005.

"Between the Wheels: the 1919 Charlotte Streetcar Strike," presented to the Georgia Association of Historians, held at Kennesaw State University, April 2004.

"Close Support for V Corps: $17^{\text {th }}$ U.S. Army Ordnance Bomb Disposal Squad in ETOUSA, 1944-45." presented to the $12^{\text {th }}$ WCU Graduate School Research Symposium, held at Cullowhee, NC, April 2004.

"Between the Wheels: the 1919 Charlotte Streetcar Strike," presented to the $12^{\text {th }}$ WCU Graduate School Research Symposium, held at Cullowhee, NC, April 2004.

"Another Day in the Life: $12^{\text {th }}$ U.S. Army Ordnance Bomb Disposal Squad in Italy," presented to the $11^{\text {th }}$ WCU Graduate School Research Symposium, held at Cullowhee, NC, April 2003.

"Treason Island: the Burr Conspiracy of 1805-1807," presented at the WCU Undergraduate Research Exposition, held at Cullowhee NC, April 1999.

\section{Sessions Chairs \& Commentary:}

Moderator during Panel Discussion on Teaching with Disasters, during WVU Rush D. Holt Conference Panel, held at the WVU Mountainlair Building, April 3, 2009.

Commentator and Moderator during Western Carolina University Undergraduate Research Exposition, Department of History, April 2004. 


\section{Academic Service:}

- West Virginia University -- Curriculum and Instruction Committee (2007-2009)

\section{Professional and Collegiate Associations:}

- Golden Key International Honour Society (Fall 2008)

- American Historical Association

- Phi Alpha Theta (Spring 2004)

- Civil War Preservation Trust

- National Trust for Historic Preservation

- Nature Conservancy

\section{Foreign Languages:}

- Spanish: High-functioning in speaking, writing, and reading skills.

- French and Italian: Reading knowledge, limited speaking ability.

- Turkish: U.S. Army Head Start Course.

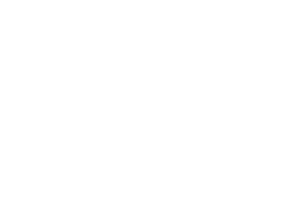

